\author{
UNIVERSIDADE DE SÃO PAULO \\ FACULDADE DE FILOSOFIA, LETRAS E CIÊNCIAS HUMANAS \\ DEPARTAMENTO DE FILOSOFIA \\ PROGRAMA DE PÓS-GRADUAÇÃO EM FILOSOFIA
}

THANA MARA DE SOUZA

DA ESTÉTICA À ÉTICA: UMA ANÁLISE COMPREENSIVA DAS OBRAS LITERÁRIAS DE SARTRE E MALRAUX

SÃO PAULO

2008 
UNIVERSIDADE DE SÃO PAULO

FACULDADE DE FILOSOFIA, LETRAS E CIÊNCIAS HUMANAS

DEPARTAMENTO DE FILOSOFIA

PROGRAMA DE PÓS-GRADUAÇÃO EM FILOSOFIA

\section{DA ESTÉTICA À ÉTICA: UMA ANÁLISE COMPREENSIVA DAS OBRAS LITERÁRIAS DE SARTRE E MALRAUX}

THANA MARA DE SOUZA

Tese apresentada ao programa de Pós-Graduação em Filosofia do Departamento de Filosofia da Faculdade de Filosofia, Letras e Ciências Humanas da Universidade de São Paulo, para obtenção do título de Doutor em Filosofia sob a orientação do Prof. Dr. Franklin Leopoldo e Silva.

SÃO PAULO 
"Quanto mais fundamente penso, mais

Profundamente me descompreendo.

O saber é a inconsciência de ignorar..."

Fernando Pessoa (Primeiro Fausto - segundo tema)

À minha avó Rosa (in memorian) e ao meu avô Nico (in memorian), por me ensinarem através de histórias... 


\section{AGRADECIMENTOS}

A meus pais, Vitor e Neuza, a meu irmão Kiko e a minha avó Maria pelo amor, carinho, compreensão e diálogo. Sem o apoio e estímulo de vocês, esta tese não seria possível.

A todos os familiares.

Ao Bruno pelo amor, respeito e pela presença, fundamental, em minha vida. Sem sua compreensão, esta tese também não seria possível.

Ao Franklin pela orientação e comentários que me faziam compreender melhor o que eu mesma havia escrito. Sem sua bondade, esta tese não existiria.

Aos amigos por mais quatro anos de companhia nos caminhos e descaminhos da filosofia e da vida.

Às secretárias do Departamento de Filosofia, ao Departamento e à Faculdade de Filosofia, Letras e Ciências Humanas da USP.

Aos Professores Hélio Salles Gentil e Júlio Pimentel Pinto pela leitura e conselhos na qualificação. Ao Professor Renaud Barbaras por me orientar na Université Paris 1 (Panthéon - Sorbonne).

À FAPESP, pelo apoio financeiro. 
"Penso que cumprir a vida seja simplesmente Compreender a marcha e ir tocando em frente.

Como um velho boiadeiro levando a boiada, Vou seguindo os dias pela longa estrada eu vou, Estrada eu sou."

Almir Sater e Renato Teixeira (Tocando em Frente) 


\title{
RESUMO
}

Esta tese pretende mostrar a relação que se pode estabelecer entre uma estética e uma ética em Sartre e Malraux. Por meio de suas obras literárias e teóricas, veremos que a arte para o primeiro se mostra como crítica aos valores burgueses de abstração e, se permite um afastar-se do real, é apenas para mais compreensivamente voltar-se para ele; enquanto para o segundo a arte se mostra como possibilidade de fuga do caos do mundo sem valores e como busca de uma nova noção de homem.

Embora de modo bastante distinto, tanto Sartre quanto Malraux fazem relação entre a arte e a realidade, entre a estética e a ética. E são as semelhanças e distinções dessa relação que pretendemos compreender nesta tese de doutorado.

Palavras-Chave: Sartre, Malraux, Ética, Estética.

\begin{abstract}
This thesis explore the relation that can be established between an aesthetics and an ethics in Sartre and Malraux. Based on their literature and theoretical works, we will show that, for the first art is critics to the bougeois values of abstraction which allows a distance from the real as a more sympathetic way to return to it; while for the second art can be seen as a possibility to scape from the chaos of the world with no values as well as a search for a new concept of man.

Despite the very different approaches, both Sartre and Malraux relate arte and reality, aesthetics and ethics. An the similarities and distinctions of these relations are wath we intend to understand in this doctoral thesis.
\end{abstract}

Key-Words: Sartre, Malraux, Ethics, Aesthetics. 


\section{ÍNDICE}

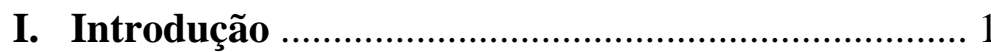

II. Capítulo 1 - Os contos de juventude ....................... 22

a) Os contos de Malraux ...................................... 28

b) Os contos de Sartre ........................................ 48

III. Capítulo 2 - Os romances de Malraux .................. 84

a) Os Conquistadores ........................................ 89

b) A Via Real ....................................................... 122

c) A Condição Humana ...................................... 145

IV. Capítulo 3 - Os romances de Sartre ....................... 188

a) A Idade da Razão .......................................... 192

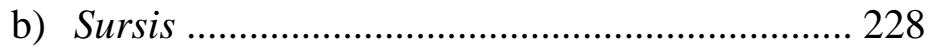

c) Com a Morte na Alma ...................................... 265

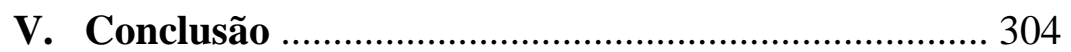

VI. Referências Bibliográficas ....................................... 321 


\section{INTRODUÇÃO \\ A QUESTÃo ESTÉTICA}

O tema da tese de doutorado, a questão da relação entre a estética e a ética, será visto a partir da filosofia de Sartre, que não as identifica mas mostra um caminho de uma em direção à outra. Em O Imaginário o filósofo diz que a percepção (mundo da ética) e a imaginação (mundo da estética) nunca podem se dar juntas: se percebo, não imagino. $\mathrm{O}$ ato de imaginar implica uma negação da percepção, e esta implica a recusa da negação operada pelo imaginário. No entanto, se é certo que as duas não podem se encontrar ao mesmo tempo, se uma exclui a outra, é certo também que uma chama pela outra, uma se volta para a outra e se completa nela:

Tout imaginaire paraît 'sur fond de monde', mais réciproquement toute appréhension du réel comme monde implique un dépassement caché vers l'imaginaire. Toute conscience imageante maintient le monde comme fond néantisé de l'imaginaire et réciproquement toute conscience du monde appelle et motive une conscience imageante comme saisie du sens particulier de la situation ${ }^{1}$.

O imaginário, mundo da obra de arte, parte do real, dá-se mantendo o real como pano de fundo, e se volta para ele; e o real, para ser compreendido, para ter seu sentido apreendido, apela ao imaginário. O sentido de "mundo", de "obra" (dados do real) é dado pela imaginação, mas por uma imaginação que não é de modo algum totalmente abstrata: é movimento de distanciamento que não esquece o mundo que mantém como pano de fundo. "L'imaginaire représente à chaque instant le sens implicite du réel"'.

Assim, o real clama pelo imaginário e este se volta para o real. Essa é a relação entre a estética e a ética: se uma não se dá de modo algum ao mesmo tempo que a outra, a ética necessita de uma "completude" que só a estética poderia dar (uma moral deve ser inventada, criada do nada, do mesmo modo que a obra de arte é), e a estética parte do real e se volta para ele, exigindo, assim, uma ética. Embora não se deva confundir ética com estética, uma moral com uma obra de arte, elas se complementam, uma se volta para a outra.

\footnotetext{
${ }^{1}$ SARTRE. L'imaginaire - p. 361.

${ }^{2}$ IBIDEM - p. 360.
} 
É, pois, partindo da concepção sartriana de estética e ética que pretendemos mostrar a relação entre ambas no próprio Sartre e em Malraux. Por meio das obras literárias de cada um e das noções de estética que exibem em seus textos mais teóricos, pretendemos mostrar como essa se relaciona com a ética nunca formulada mas sempre entrevista em suas obras e vidas.

Concordando com Sartre, tentaremos mostrar como a estética exige uma ética, como principalmente a prosa, por usar as palavras como significantes, dirige-se ao mundo real e o revela de um determinado modo - e esse modo é que nos irá mostrar qual ética deixa ser vista pela obra. Como o filósofo diz em Situações I, "uma técnica romanesca sempre remete à metafísica do romancista. A tarefa do crítico é evidenciar esta antes de apreciar aquela" ${ }^{3}$; é preciso descobrir, então, para além do romance, a metafísica do autor - e é isso que faremos nessa tese: mostrar como as obras literárias de Sartre e Malraux revelam uma "metafísica" do autor, revelam o modo como eles pensam e desejam desvelar seu mundo; o que é uma questão ética.

Não se trata de encontrar teorias estéticas e éticas acabadas, prontas, mas sim de indicar os vestígios de como a obra literária revela o modo como os autores viam a situação do homem contemporâneo no mundo. Nenhum dos dois escreveu uma "Estética" e uma "Ética", e o que pretendemos fazer aqui não é escrevê-las. Tentaremos apenas esboçar como poderíamos entrever as problemáticas essenciais para cada um deles, tanto no que se refere a uma estética, quanto ao que se refere a uma ética. E embora Sartre tenha escrito Que é a literatura?, não se trata propriamente de uma "teoria estética" - é um ensaio de circunstância (escrito logo após a segunda guerra mundial como resposta aos que o criticavam de submeter a arte a um engajamento político) do qual podemos e iremos deduzir as questões que nos servirão de guia para nosso escrito.

Partiremos, então, da "teoria estética" sartriana, mais precisamente da teoria sobre a prosa. Sem poder elencar todas as questões que são postas no ensaio Que é a literatura? e que necessitam, para ser bem compreendidas, da comparação com outros livros de Sartre (como $A$ imaginação e $O$ imaginário $)^{4}$, mostraremos aqui apenas

\footnotetext{
${ }^{3}$ SARTRE. Situações I- p. 93.

${ }^{4}$ Esse foi o tema de minha dissertação de mestrado. Para quem deseja se aprofundar nessa questão, conferir SOUZA, T. Sartre e a literatura engajada: espelho crítico e consciência infeliz.
} 
algumas poucas questões centrais e sem o desenvolvimento necessário, apenas para explicitar os pressupostos de nossa tese.

Para Sartre, a prosa se distingue das outras obras de arte porque trata a palavra como significante: enquanto a pintura vê a cor como coisa, como objeto, e a própria poesia vê a palavra como coisa (interessada mais no som e relação entre as palavras do que no significado, ao menos de modo primeiro e mais fundamental), a prosa trata a palavra como instrumento, significante; e portanto, fazendo referência a algo que não é ela.

E ao se referir a algo que não é ela, a palavra revela o significante, transforma aquilo que nomeia. É, pois, por esse poder que a palavra exibe de nomear e transformar as coisas e as situações que Sartre afirma que a prosa é engajada. O engajamento seria o desvelamento do mundo por meio das palavras, o modo como o escritor decidiu revelar tal situação e se calar sobre outra, e o modo como o leitor se viu refletido (por meio de um "espelho crítico") e agiu perante sua nova imagem.

O engajamento da prosa não seria nada mais do que a revelação reflexiva do engajamento que todo homem é: por estarmos no mundo, por não podermos fugir dele, todo ato e toda não-ação são relações com o mundo, dizem respeito a ele e exigem o comprometimento de quem o faz; assim como toda fala e todo silêncio nos inserem ainda mais no mundo do qual não podemos escapar. Mas se todos estamos engajados, tentamos o tempo todo negar esse comprometimento: e o papel da prosa seria justamente o de revelar, pela significação e comunicação que a palavra exige, esse engajamento que somos.

O escritor mostraria ao leitor, por meio da prosa, que aspecto do mundo pretende revelar e transformar; e o leitor, ao ler a prosa, mostraria ao escritor e aos outros como assumiria ou rejeitaria essa nomeação e transformação. $\mathrm{O}$ engajamento da prosa seria esse desvelamento do mundo, diante do qual tanto o escritor quanto o leitor teriam que se comprometer (o primeiro pelo modo como escreveu tal situação; o segundo pelo modo como reagiu), diante do qual nenhum dos dois poderia mais fingir que ignora o mundo e sua inserção nele, que se dá em cada ato e em cada fuga. "O escritor apresenta a imagem da sociedade e a intima a assumi-la ou então a transformar-se. E de qualquer modo ela muda, perde o equilíbrio que a ignorância lhe 
proporcionava, oscila entre a vergonha e o cinismo, pratica a má-fé; assim, o escritor dá à sociedade uma consciência infeliz"

Não se trata, portanto, de pensar em uma obra engajada como "política" no sentido estrito. Sartre não pretende colocar a arte a serviço da política, pelo contrário: em Que é a literatura?, diz que o escritor não deve fazer parte de um partido para atingir o público: "Caso se pergunte hoje se o escritor deve, para atingir as massas, oferecer os seus serviços ao partido comunista, respondo que não; a política do comunismo stalinista é incompatível com o exercício honesto do ofício literário"6. Como obra da liberdade do escritor, a prosa não deve estar presa a nenhuma ideologia partidária.

Assim, o engajamento e a ética que podemos entrever na prosa não estão relacionados à política no sentido estrito, mas sim no sentido mais lato de que todos estamos comprometidos nesse mundo e devemos assumir nosso modo de nos inserirmos ou de fugirmos. E se podemos entrever uma ética a partir da prosa, é porque ela é o aspecto de mundo que o escritor, livremente, decidiu nomear e transformar - e é por sua escolha que deve ser responsabilizado.

A maneira pela qual o escritor cria seus romances nos revela o modo como ele vê seu mundo e como pretende mostrar sua relação com a realidade que o cerca. $\mathrm{O}$ escritor deve ser responsabilizado pelo que escreve (afinal, ele decidiu falar sobre tal aspecto e se calar sobre outro) e por meio de sua obra, que nos revela uma maneira de pensar a arte, podemos entrever também um esboço de uma ética.

É com essa relação entre estética e ética, entre a prosa e o engajamento, palavra e o comprometimento, que tentaremos analisar alguns romances de Sartre e Malraux. E embora seja necessário o conhecimento de teorias estéticas, nosso ponto de partida é a filosofia de Sartre, e é com ela nos guiando que tentaremos compreender os romances e como esses nos deixam entrever os esboços de uma ética em Sartre e Malraux.

Trata-se de uma tese de filosofia, o que não dispensa considerações propriamente estéticas e históricas (que serão estudadas após a análise dos romances), mas que não se identifica com elas. Assim, se os romances serão a base para a

\footnotetext{
${ }^{5}$ SARTRE. Que é a literatura? - p. 65.

${ }^{6}$ IBIDEM - p. 188.
} 
compreensão da questão da relação entre estética-ética, eles serão vistos principalmente à luz dessa relação, e não apenas neles mesmos.

Devido à formação filosófica da autora, as questões de teoria estética não serão tratadas da forma necessária, mas também não serão totalmente ignoradas. Se infelizmente é certo que os romances se mostrarão muito mais pobres do que são (devido à incompetência da autora para fazer uma análise estritamente literária, considerando as estruturas e complexidade de uma língua que se transforma ao se colocar a serviço da ficção), haverá ao menos a tentativa de ler o romance nele mesmo, acompanhando a maneira de narrar e os acontecimentos. Mesmo que de uma maneira ingênua, acompanharemos as narrações e tentaremos levar em consideração os aspectos que fazem da prosa uma obra de arte e não apenas uma comunicação direta e denotativa.

No entanto, o que pretendemos mostrar é uma questão filosófica: a da relação entre estética e ética nas obras literárias de Sartre e Malraux; e a teoria que iremos adotar - a de que existe essa relação porque a palavra é nomeação e transformação, e o escritor deve ser responsabilizado pela transformação que tentou realizar; revelando, portanto, que podemos ver uma ética na forma e conteúdo narrativos - é a teoria de um filósofo, de Sartre.

Se o romance sairá enfraquecido (e aqui perço perdão aos teóricos literários), talvez seu enfraquecimento ao menos sirva para enriquecer uma filosofia que tende a se tornar cada vez mais burocrática e menos filosófica, cada vez mais abstrata e menos fictícia (pensando a abstração como invenção sem relação com o mundo no qual vivemos, e a ficção como uma maneira "outra" de revelar o mundo, que cria mas não se afasta jamais do real, mesmo nas mais ilógicas e fantásticas invenções), cada vez mais árdua e menos bonita. Como diz Benedito Nunes, "ao conhecer a literatura, a filosofia tende a ir ao encontro de si, a fim de não somente interrogá-las, mas também, refletindo sobre um objeto que passa a refleti-la, interrogar-se diante e dentro dela"7. Se conseguirmos tornar a filosofia mais bonita sem que o rigor seja abandonado, ao menos teremos uma compensação para o indesculpável empobrecimento dos romances.

\footnotetext{
${ }^{7}$ NUNES, B. "Literatura e Filosofia (Grande Sertão: veredas)" In LIMA, L. Teoria da literatura em suas fontes 1 - p. 217.
} 
Mas uma questão deve ser colocada desde já: se dissemos que nosso ponto de partida é a filosofia sartriana, e se com ela iremos compreender os romances de Sartre e Malraux à luz da relação entre estética e ética; não seria isso impôr uma questão que é própria à Sartre aos romances de Malraux? Não seria "violentar" os textos de Malraux para ver neles uma relação que ele não coloca mas que está em Sartre? Não seria um tratamento desigual, já que partimos de Sartre para analisar seus romances e também os de Malraux, sem considerar em primeiro plano suas próprias questões sobre a arte?

Pensamos que não.

Malraux, assim como Sartre, não escreveu uma "Estética" mas escreveu textos que tratam da questão da arte. E nos livros que tratam diretamente da obra de arte (escritos principalmente quando não mais escrevia romances; quando passou a ser ministro do General de Gaulle), temos mais uma tentativa de catalogar as obras particulares (não com classificações mas principalmente pensando em questões de metamorfose, de transformações que nos permitem uma certa eternidade, um modo de se libertar do tempo) do que uma questão sobre a ética e o comprometimento do artista.

Não vemos em Malraux um tratamento direto do engajamento, a cobrança de um posicionamento do artista. Pelo contrário: a arte para ele seria um modo de se lutar contra o destino que nos humilha, seria uma maneira de buscar a transcendência e a perpetuação do mundo, garantida não pela continuidade, mas pelas metamorfoses. Para o escritor, o artista não é alguém que imita, que copia o mundo, mas sim aquele que se mostra como rival do real, aquele que tenta, por meio do fantástico ou não, sair das humilhações que a violência e a morte nos impõem.

Não temos, portanto, a mesma relação que Sartre estabelece entre a prosa e o comprometimento. A arte para Malraux se mostra mais transcendente, com desejos de se colocar como rival do mundo, e assim, superar o destino que nos limita e nos humilha. No entanto, podemos ver, nesse modo de pensar a arte, também uma questão que se nos revela ética. Se não foi feito e talvez nem seja desejado por Malraux, esse prolongamento é possível e coerente: dizer que a arte é uma tentativa de combater o destino que nos humilha, é dizer que ela se relaciona com o mundo em que vivemos. Mesmo que no modo da fuga e da oposição, é ao mundo real da morte e da humilhação que ela se volta, ao qual tenta se opor. 
Teríamos aqui uma certa ética, um aspecto ético do papel do artista e da arte, já que eles seriam rivais do mundo, proporiam um outro mundo no qual existiria uma possibilidade de fugir ao tempo, de permanecer na transformação (que é, em termos bastante gerais, a idéia do Museu Imaginário, de um museu que não é real mas que congregaria as artes, relacionando-as e mostrando uma "eternidade" por meio da metamorfose). A arte seria um meio privilegiado no combate à perda dos valores, tendo "pour mission d'opposer à la destruction et au chaos universel sa pérennité et son ordre" 8 .

Não se trata de modo algum de uma ética como a pensada por Sartre (e a que seguiremos), totalmente relacionada às nossas vivências e de modo direto, mas também podemos ver em Malraux questões que poderiam ser prolongadas em um sentido ético, de como o artista, ao ser rival do real, propõe um outro mundo no qual a humilhação poderia ser vencida - e que ao fazer isso, deveria se responsabilizar por essa maneira de mostrar um outro mundo.

Claro que isso é colocar uma questão que não foi tratada por Malraux e que muito provavelmente ele não aceitaria: pensar na responsabilidade do artista é pensar a obra como fruto de sua subjetividade livre e inserida totalmente no mundo, é ter como base a teoria sartriana. De todo modo, podemos ver um sentido ético no modo de se pensar a arte: mesmo que não de modo explícito como Sartre, mesmo que não seja uma ética da responsabilidade e comprometimento (do engajamento), podemos inferir "pinceladas" éticas no modo de Malraux pensar o papel da arte no mundo.

E há algumas frases do próprio Malraux que poderiam nos autorizar essa inferência, como essa, por exemplo: “Dès que la question 'Qu'est-ce que 1'art?' devient sérieuse (...) la question 'Qu'est-ce que 1'homme?' n'est pas loin"'. E se a pergunta sobre a arte se torna a questão sobre o homem, não é uma violação dizer que pensar a arte também é pensar um modo do homem viver, um modo dele estar nesse mundo e tentar se livrar das humilhações do destino - é, enfim, pensar em questões éticas.

Por isso, embora Malraux não trate diretamente da relação entre estética e ética, pensamos que, de uma maneira outra e mais sutil, também podemos estabelecer

\footnotetext{
${ }^{8}$ VANDEGANS. La jeunesse littéraire d'André Malraux - pp. 291-292.

${ }^{9}$ Cf. introdução de HARRIS. L'éthique comme fonction de l'esthétique. Trata-se de uma entrevista dada por Malraux à Les Nouvelles Littéraires em 1952.
} 
essa relação aqui. E será justamente a necessidade dessa relação, mas a maneira diversa como Sartre e Malraux a estabelecem, que trataremos nessa tese.

Assim, se Malraux não mostra explicitamente uma relação entre estética e ética, seu modo de pensar a arte se relaciona (mesmo que implicitamente) com o modo como vê seu mundo. Mesmo partindo da "teoria" sartriana, não estamos, portanto, violentando Malraux ao dizer que nele também podemos ver questões estéticas que se desdobram em questões éticas (em nenhum dos dois, no entanto, vemos uma teorização de ambas, uma ética e uma estética acabadas, prontas. Mas há esboços, preocupações, questões - e são elas que indicaremos aqui).

Podemos dizer também que essa questão da relação entre a estética e a ética, a arte e a realidade, mostra-se geral na época em que Sartre e Malraux viveram, na época do entre-guerras e segunda guerra mundial e também da Libertação. Nesse mundo tão cheio de guerras, a historicidade se fez muito presente - e os artistas voltaram suas preocupações para a história e não deixaram de considerar a relação de suas obras com o mundo em que viviam. Mesmo que de maneiras distintas, com intenções diferentes, os escritores da geração de Sartre e Malraux tinham como preocupação essa questão de como e se a arte se relacionava com a realidade.

A maioria dos escritores franceses do entre-guerras e pós-guerra engaja-se nas questões políticas de sua época, seja através de seus livros ou também na prática, participando ativamente da Resistência ou mesmo se aliando aos nazistas - caso de Drieu La Rochelle. Segundo Lévy, em As aventuras da liberdade ${ }^{10}$, essa relação estreita entre escritores e política ${ }^{11}$ iniciou-se com o caso Dreyfus, momento no qual surge a palavra intelectual e escritores se unem para intervir em assuntos que não propriamente literários; e termina no início dos anos 80, quando os escritores se voltam para os problemas especificamente estéticos.

Durante todo esse período, vários acontecimentos históricos "pedem"o apoio ou o repúdio de toda a população, e grande parte dos escritores não foge diante desse pedido: revolução russa, crise econômica mundial, surgimento do nazismo, revoltas na Indochina, guerra civil espanhola, segunda guerra mundial - eis alguns dos eventos que pediam o posicionamento de todos. E diante de todo esse caos, Sartre diz que os escritores descobriram-se bruscamente situados, mergulhados na lama da história: “A

\footnotetext{
${ }^{10}$ LÉVY, B. As aventuras da liberdade.

${ }^{11}$ Entendendo política no seu sentido mais amplo.
} 
historicidade refluiu sobre nós; em tudo o que tocávamos, no ar que respirávamos, na página que líamos, naquela que escrevíamos, no próprio amor, descobríamos algo como um gosto de história, isto é, uma mistura amarga e ambígua de absoluto e transitório"12. e assim, acabaram por fazer uma literatura de historicidade.

Ao analisar sua geração, que denomina como terceira geração (que começou a escrever depois da derrota ou pouco antes da segunda guerra mundial), Sartre mostra como a história aparece de modo vertiginoso para esses jovens escritores e estudantes, que ainda pensavam na impossível beleza e abstração ${ }^{13}$.

Mas essa não foi uma descoberta apenas de Sartre: essas situações extremas, vivenciadas na primeira metade do séc. XX, levaram muitos escritores a descobrir esse gosto amargo da história. Camus, ao analisar o livro A Náusea, de Sartre, diz: "uma obra duradoura não pode deixar de lado o pensamento profundo. Esta fusão estrita da experiência com o pensamento, da vida com a reflexão sobre seu sentido, é o que faz o grande romancista (tal como se manifesta em um livro como $A$ condição humana, por exemplo)"14. E Malraux também afirma que "ce qui nos distinguait de nos maîtres, à vingt ans, c'était la présence de l'histoire. Pour eux, ils ne s'était rien passé. Nous, nous commençons par de tués. Nous, nous sommes de gens dont l'histoire a traversé le champ, comme une char"'15.

Assim, os grandes escritores franceses do entre-guerras descobriram esse gosto de história e perceberam-se totalmente situados nesse mundo, retratando em seus livros a angústia e felicidade diante dessa descoberta. Esses escritores - e podemos citar, além de Sartre e Malraux, Camus, Bernanos, Beauvoir e outros - fizeram uma literatura de historicidade, uma estética que não se separa totalmente da ética, da situação vivida tantos pelos escritores quanto pelos leitores.

Esse "diagnóstico" é feito não apenas pelos próprios escritores mas também pelos críticos. Albérès (em La révolte des écrivains d'aujourd'hui) identifica na literatura da primeira metade do séc. XX preocupações comuns como a de mostrar a revolta em relação às regras sociais. Para ele, muitos dos escritores, mesmo que com concepções diferentes (como Sartre, Camus, Malraux e Bernanos) têm algo em

\footnotetext{
12 SARTRE. Que é a literatura? - p. 158.

${ }^{13}$ Cf. SARTRE. Que é a literatura? - parte IV (A situação do escritor em 1947).

${ }^{14}$ CAMUS: “A Náusea, de Jean-Paul Sartre" in A inteligência e o cadafalso - p. 133, grifos nossos.

${ }^{15}$ LACOUTURE. Malraux, une vie dans le siècle - p. 9.
} 
comum: seus heróis são como Prometeu, ou seja, têm como aventura construir seu destino sozinho, sem a ajuda de uma norma social ou de uma graça divina.

Seguindo a "crise moral" do final do séc. XIX, com a decepção na ciência e na razão, e a angústia metafísica sem Deus (vistas de modo forte e ímpar em Nietzsche e Dostoievski), a literatura do séc. XX inicia com uma "crise do espírito", com uma reação perante a constatação desse mundo no qual Deus não mais existe, e se existe, nada mais pode. "Tous les romanciers-penseurs contemporains ont été, d'une manière ou d'une autre, marqué par ces différents courants d'influences. Ceux d'entre eux qui en sont le plus fortement imprégnés choississent la révolte, refusent la morale, la religion et toutes les valeurs que la tradition a reconnues transcendant l'humanité"16.

Também Chiheb, na tese em que compara os romances de Sartre e Malraux, mostra que há uma preocupação comum a esses dois escritores (e poderíamos estender essa preocupação a muitos outros escritores da mesma época), preocupação essa que se revela fortemente relacionada à história: "En effet, outre la communauté de points de vue métaphysiques, on trouve chez Malraux et Sartre le même intérêt, la même préoccupation et la même inquiétude à l'égard des convulsions de leur époque: la guerre, le communisme, le facisme, la révolution, la place de l'homme dans la societé et dans l'Histoire etc"'17.

Há, portanto, uma temática comum a grande parte dos escritores da primeira metade do século $\mathrm{XX}$, que é a historicidade na qual se vêm inseridos, na qual mergulham. A desfragmentação da história e do próprio sujeito, questão enfatizada pelas guerras, leva ao romance a questão dessa totalidade que não mais existe, se é que algum dia existiu. Assim, a prosa do séc. XX coloca a história e o homem como tema, e sua forma fragmentária revela a situação do homem nesse mundo em pedaços e sem mais um sentido pleno. E por colocar a questão da totalidade inexistente e da fragmentação do sujeito, a prosa se torna ética ${ }^{18}$. A questão do sentido do mundo e do

\footnotetext{
${ }^{16}$ KPOGODO. Contestation des valeur morales et religieuses dans le roman contemporaine (Malraux, Sartre, Camus) - p. 63.

${ }^{17}$ CHIHEB. L'esthétique romanesque chez André Malraux et Jean-Paul Sartre dans Les Conquérants, La condition humaine, L'espoir, L'âge de raison, Le sursis et La mort dans l'âme - p. 7.

${ }^{18} \mathrm{Cf}$. LUKÁCS. A teoria do romance. Embora o próprio autor, posteriormente, revele os limites de seu texto, o quanto este estava condicionado à época em que o escreveu, essa revelação da ética como tema e estrutura do romance se tornou uma temática comum aos historiadores da literatura. Podemos ver essa mesma questão em ALBÉRÈS (La révolte des écrivains d'aujourd'hui), BOISDEFFRE (Littérature d'aujourd'hui), FITCH (Le sentiment d'étrangeté chez Malraux, Sartre, Camus et Simone de Beauvoir), GODARD (Une grande génération), KPOGODO (Contestation des valeur morales et religieuses dans le roman contemporaine (Malraux, Sartre, Camus), e em TADIÉ (Le roman au XXe. siècle). Mesmo que com algumas diferenças, esses e outros comentadores insistem na questão da presença de temas éticos no
} 
próprio homem se torna a problemática do romance, ao menos a do romance do séc. XX: "No romance a intenção, a ética, é visível na configuração de cada detalhe e constitui, portanto, em seu conteúdo mais concreto, um elemento estrutural eficaz da própria composição literária"19.

Nesse mundo abandonado por Deus, no qual a história parece desmoronar-se em meio a tantas guerras, o homem também se encontra na beira de um precipício, não encontrando mais seguranças nem em Deus nem na história: é ele, perdido e também em processo de desfragmentação, que deve encontrar um sentido no que faz e no que vê. É nele, sem mais crenças (em Deus, na ciência, na história, nele mesmo) que deve buscar a esperança (e é dessa idéia que Mounier tira o título de seu livro: $A$ esperança dos desesperados).

Também Tadié, em seu Le roman au XXe. siècle, mostra o quanto o romance tenta, na forma e no conteúdo, revelar a fragmentação do sujeito: através do desaparecimento do personagem clássico (o do século XIX), os escritores mostram como o indivíduo caminha em direção a seu desaparecimento: há uma decomposição do eu, uma experiência da contingência que acontece na vida real e se mostra também no romance, tanto nas narrativas de personagens que se buscam em se perdendo, quanto nas formas dos personagens sem nomes, das cidades inexistentes, na perda de identidade e profissão.

Se o que caracteriza o surgimento do romance é justamente a importância dada à individualização do personagem (isso no século XVIII e para Ian Watt) ${ }^{20}$, o romance do século XX é aquele que tenta desindividualizar o personagem, é aquele que mostra um personagem individualizado mas incompleto, imerso no mundo desfragmentado que não é senão uma imagem de sua própria desintegração. No mundo de guerras mundiais, o homem tenta se encontrar - e perdido, só pode recorrer aos estilhaços de seu mundo, de si próprio.

Há, pois, nos escritores da primeira metade do século $\mathrm{XX}$, o descobrimento angustiante da historicidade que somos; e nessa descoberta, descobrimo-nos perdidos em meio a um mundo partido, tão desfragmentado quanto nós. Esse é o mundo no qual esses escritores viviam, e é essa questão da busca de um sentido que não é (mais)

romance da primeira metade do séc. XX, em como o próprio sujeito no mundo se torna tema e forma dos romances.

${ }^{19}$ LUKÁCS. A teoria do romance - p. 72.

${ }^{20} \mathrm{Cf}$. WATT. A ascensão do romance. 
possível mas que não podemos deixar de buscar que seus romances, de modo geral, mostram.

Assim, mesmo que tenhamos partido da relação que Sartre estabelece entre a estética e a ética, mesmo que essa teoria tenha sido escolhida como orientação, vimos que essa questão não é alheia aos pensamentos e obras de Malraux e que além disso, perfazem uma preocupação comum a grande parte dos escritores da mesma geração, da mesma época. Por isso, mesmo que Malraux não tenha tratado diretamente dessa questão, podemos dizer que sua prosa também nos revela um modo de se pensar o homem no mundo, e portanto, um modo de se esboçar uma ética.

Tanto Sartre quanto Malraux quanto muitos outros escritores da mesma "geração" tentam criar, por meio do romance, essa desfragmentação tão vivenciada no século XX. E por isso a ética se encontra presente no romance (não uma ética pensada como uma prescrição e descrição do que deve ser feito, mas como questionamento sobre nossa insegurança, sobre nossa angústia por não termos mais deuses nem moral).

Essa relação entre a arte e a realidade, a estética e a ética, encontra-se, no entanto, de modo muito mais forte na prosa que nas outras artes.

E se novamente partiremos da filosofia de Sartre para estabelecer essa relação mais forte da prosa com a realidade, não nos limitaremos apenas a ela: alguns comentadores, de diversas teorias literárias, também mostram como a prosa se relaciona com o mundo de modo diverso que a poesia e outras artes.

Para Sartre, a prosa e a poesia se distinguem das outras artes porque elas usam como instrumento as palavras, bem distintas das cores e sons e formas, que são utilizados pela pintura, música e escultura. Por utilizar a palavra, a prosa e a poesia parecem estar mais próximas de um engajamento mais direto, enquanto as outras artes, por utilizarem outros instrumentos, afastam-se desse engajamento, ao menos de modo direto e explícito.

Mas logo depois Sartre diz que a prosa e a poesia não se igualam por usarem das palavras. Cada uma utiliza a palavra de um modo, e por isso se distinguem. O poeta olha a palavra como o pintor olha a cor: como uma coisa; enquanto o prosador olha a palavra como instrumento, como signo de algo. Ao poeta é a própria palavra que mais importa (não que ele desconsidere o sentido da palavra, mas em primeiro 
lugar é a sonoridade, a combinação de palavras que mais importa), enquanto ao prosador é a referência que mais importa (também em primeiro lugar, de modo prioritário. Todo escritor é assim considerado pelo estilo que adota, e por isso também pensa na sonoridade, na própria palavra; mas em um primeiro momento o mais importante é, segundo Sartre, o significado da palavra e não a própria palavra).

Por isso Sartre diz que é na prosa, de modo prioritário, que podemos ver o engajamento (isso em Que é a literatura?, escrito em 1948. Mais tarde, em artigos, ele dirá que também a poesia e a pintura podem ser engajadas, mas esse engajamento se dá de modo distinto, mais indireto: não é pela nomeação e desvelamento que o engajamento se dá, mas sim pelo modo como o poeta e o pintor colocam o mundo e a si mesmos na própria arte).

De forma mais forte e prioritária, o engajamento se encontra na prosa, e isso se dá porque apenas ela se relaciona diretamente com o mundo, porque apenas ela utiliza a palavra como significado, fazendo referência a algo que não ela mesma. Assim, a relação da prosa com a realidade é intrínseca, se dá de modo mais direto que nas outras artes.

É isso que também alguns críticos mostram:

Barthes, em Le degré zéro de l'écriture, fala da distinção entre a poesia clássica e a poesia moderna. Segundo ele, nos tempos clássicos havia uma diferença apenas de grau (e não de essência) entre a prosa e a poesia: esta era a prosa mais o ormanento. Mas a poesia moderna se mostra como substância, como essencialmente distinta da prosa: "La poésia moderne (...) détruit la nature spontanément fonctionnelle du langage et n'en laisse subsister que les assises lexicales. Elle ne garde des rapports que leur mouvement, leur musique, non leur vérité" 21 .

Mesmo que os propósitos sejam distintos do de Sartre, aqui também vemos a preocupação em mostrar que a palavra é vista de um modo na prosa, e de outro modo na poesia, que aqui a palavra não exerce a natureza espontaneamente funcional da linguagem. Se na prosa ainda há esse aspecto funcional, na poesia a palavra guarda apenas seu movimento, sua música.

Também Bakhtin viu essa diferença essencial entre a prosa e a poesia:

${ }^{21}$ BARTHES. Le degré zéro de l'écriture - p. 68. 
O discurso poético, no sentido estrito, exige a uniformidade de todas as palavras, sua redução a um denominador comum (...). Uma das peculiaridades essenciais da ficção em prosa é a possibilidade que ela abre de se empregarem diferentes tipos de discurso, mantendo intacta, ao plano de uma obra isolada, a sua distinta expressividade, sem a redução a um denominador comum. Aqui, reside uma profunda diferença entre o estilo em prosa e o estilo em poesia ${ }^{22}$.

Para ele, o discurso poético exige a uniformidade de todas as palavras, a preocupação com um denominador comum, enquanto o discurso da prosa admite vários tipos de discurso, várias expressividades. Um discurso poético teria de ser mais uniforme, pensar mais nas próprias palavras, enquanto o outro admite mais variedade, outras preocupações que não com a musicalidade das palavras.

Embora com intenções diferentes, podemos ver em Sartre, Barthes e Bakhtin uma mesma preocupação em distinguir a prosa da poesia, em fazer desta uma arte que coloca a palavra num plano mais alto, mais autônomo, como se ela fosse, de certo modo, uma "coisa" que pudesse ser vista nela mesma, como se tirássemos sua funcionalidade, sua referencialidade do dia-a-dia. Ela seria o objeto do qual o poeta faria sua arte, tirando-a de sua função cotidiana de significar algo.

Já na prosa a palavra também se transforma, perde a referencialidade direta, a comunicação explícita, mas continua a significar, continua a fazer referência a algo que não ela mesma. Para ser arte, a prosa necessita do estilo, e por isso não se identifica com os diálogos cotidianos, nos quais a preocupação é a comunicação (e em geral da forma mais rápida e direta possível). Mas se não se identifica com a comunicação diária, se também mostra preocupações com o estilo e a sonoridade, ela não deixa de se referir a algo externo a ela, de significar alguma coisa.

Não se trata, para nenhum deles, de estabelecer uma hierarquia entre prosa e poesia, de dizer que uma é melhor que a outra; trata-se de estabelecer a diferença de duas artes que lidam com o mesmo instrumento - a palavra. Trata-se de mostrar que, embora utilizando palavras, cada uma o faz de modo distinto, e por isso devem ser compreendidas de maneiras diferentes.

\footnotetext{
22 BAKHTIN. “A tipologia do discurso na prosa” In LIMA, L. Teoria da literatura em suas fontes $1-\mathrm{p}$. 506.
} 
E é por manter esse aspecto funcional e referencial da palavra que a prosa, mais do que as outras artes, relaciona-se de modo mais direto com a realidade. E por isso escolhemos compreender romances para mostrar como se daria a relação entre a estética e a ética, entre o "mundo" da prosa e o mundo real.

No entanto, se na prosa essa relação se dá de forma mais direta porque a palavra mantém-se como significante, conserva sua referência ao mundo real, é certo que essa relação não se dá de modo totalmente direto. Se assim fosse, não seria prosa, mas apenas comunicação. Para ser arte, é necessário transformar uma mensagem com função referencial (que indica algo de univocamente definido, com uma base de referencialidade comum) em uma mensagem com função emotiva (que visa suscitar reações no receptor, promover um comportamento de resposta que vai além do simples reconhecimento da coisa indicada), é necessário conservar a referência mas torná-la subjetiva, emocional ${ }^{23}$.

E se é assim, não poderíamos de modo algum estabelecer uma relação totalmente direta entre o que se mostra na prosa e o que se passa no mundo. Se há relação intrínseca entre estética e ética, entre o mundo narrado e o mundo vivido, essa relação não se dá de forma tão direta: é mais direta que nas outras artes, mas isso não significa que é totalmente direta, que se pode passar de um mundo a outro sem considerar os estilos, as intenções e as peculiaridades de cada mundo.

Se a relação entre mundo narrado e mundo vivido é possível e necessária (porque a prosa é significado, e como tal, nomeia e transforma os dois mundos), ela não se dá de maneira simples e causal.

À questão de como mostrar, em toda sua complexidade, a passagem do mundo narrado ao mundo vivido, não ousaremos responder clara e totalmente, mas ao menos mencionaremos e esboçaremos alguns diversos modos de se compreender essa relação, tendo algumas teorias como guia, como caminhos desejáveis mas que nem sempre trilharemos (devido ao foco da tese, que não é teoria literária mas sim filosofia).

O mundo narrado não é o mundo vivido, não é o mundo real. Se se relaciona com esse, não pode ser de modo causal, determinista. Não há identidade alguma entre esses dois mundos; e é nisso que devemos prestar atenção:

\footnotetext{
${ }^{23}$ Cf. ECO, U. Obra Aberta.
} 
A obra de ficção nada tem a ver com a honestidade: ela trapaceia e só existe trapaceando. Ela tem parte, em todo leitor, com a mentira, o equívoco, um eterno movimento de engodo e de esconde-esconde. Sua realidade é o deslizamento entre o que é e o que não é, sua verdade, um pacto com a ilusão. Ela mostra e retira, vai a algum lugar e deixa crer que o ignora. É no modo imaginário que encontra o real, é pela ficção que se aproxima da verdade $^{24}$.

Como bem diz Blanchot, temos de considerar que a arte é ficção e não realidade. Embora elas se relacionem, é justamente por meio do imaginário, por meio da ficção. Não devemos estabelecer uma relação direta e causal entre a obra e a realidade. É preciso sempre considerar que lidaremos com obras de arte, com fícção, que se relacionam com a realidade através da ilusão, da mentira, da oscilação entre o que é real e o que não é. Em nossas análises de textos, tentaremos sempre atentar para esse aspecto fundamental do romance, que é o fato dele ser romance, arte, ficção, mentira - e que por isso não devemos identificar o mundo narrado ao mundo vivido.

No entanto, levar em consideração que os romances são ficção e mentira não nos deve levar ao outro extremo; o de pensá-los como "arte pela arte". O romance é ficção, é imaginário, mas se relaciona com o mundo real, com o vivido. É como Blanchot diz: "O escritor que pretende se interessar apenas pela maneira como a obra é feita vê seu interesse afundar no mundo, perder-se na história inteira; pois a obra se faz também fora dele, e todo o rigor que depositou na consciência de suas operações meditadas, de sua retórica refletida, é logo absorvido no jogo de uma contingência viva que ele não é capaz de dominar ou mesmo perceber"25. O livro, coisa escrita, entra no mundo, onde cumpre sua obra de transformação e negação.

Não devemos, portanto, nem estabelecer uma relação direta entre o mundo narrado e o mundo vivido, desconsiderando as peculiaridades da obra de arte; nem considerar a obra de arte como se não tivesse relação alguma com o mundo real. É preciso fazer a relação mas de modo a não identificar o que é narrado com o que é vivido; é preciso estabelecer uma ligação que se dá por meio de um distanciamento; um distanciamento que nos permitiria melhor compreender ao mesmo tempo o romance e o mundo.

\footnotetext{
24 BLANCHOT. A parte do fogo - p. 187.

${ }^{25}$ IBIDEM - p. 297.
} 
Como Paul Ricoeur diz, a literatura tem como função destruir o mundo,

et pourtant, il n'est pas de discours tellement fictif qu'il ne rejoigne la réalité, mais à un autre niveau, plus fondamental que celui qu'atteint le discours descriptif, constatif, didactique, que nous appelons langage ordinaire. Ma thèse est ici que l'abolition d'une référence de premier rang, abolition opérée par la fiction et par la poésie, est la condition de possibilité pour que soit libérée une référence de second rang, qui atteint le monde non plus seulement au niveau des objets manipulables, mais au niveau que Husserl désignait par l'expression de Lebenswelt et Heidegger par celle d'être-au-monde ${ }^{26}$.

Não considerar uma referência em um nível direto, de "primeiro grau", não é dizer que não há referência. Pelo contrário: por meio do distanciamento, poderemos perceber que há uma referência de segundo grau, que atinge o mundo de forma mais profunda. Esse distanciamento seria a condição de uma melhor compreensão, tanto do romance quanto do mundo.

Podemos então, em um primeiro instante, dizer que tentaremos observar em nossa tese essas considerações feitas por Blanchot e Ricoeur: a de que há uma relação entre mundo narrado e mundo vivido (ou como diz Ricoeur, entre "mundo do texto" e o mundo vivido), mas que essa relação não se dá de forma direta, causal, determinista. Ela se dá de modo ambíguo, através da ilusão, do distanciamento: é pela ilusão que nos aproximamos da verdade, é pelo distanciamento que se compreende a aproximação. Se as obras de Malraux e de Sartre não serão consideradas apenas nelas mesmas mas em suas referências ao mundo no qual viveram, não poderemos estabelecer uma relação direta entre o que é narrado e o que foi vivido. Há um poder de negação e transformação que existe em toda obra de arte e que deve ser considerado por nós.

A arte atinge o real porque o deforma, aproxima-se porque se distancia, é verdade porque é ilusão, é realidade porque é ficção. É esse aspecto ambíguo e complexo que tentaremos mostrar em nossa tese; o modo como os romances de Malraux e Sartre se relacionam com a realidade, sem considerá-los como identidade, como causalidade. A relação entre mundo narrado e mundo vivido deve ser buscada

\footnotetext{
${ }^{26}$ RICOEUR. "La fonction herméneutique de la distanciation” In Du text à l'action - p. 127.
} 
na transformação e deformação que aquele realiza, no poder de negação e imaginação que a arte é. Mas como adotar esse distanciamento proposto por Ricoeur? Como não cair em uma relação causal, extremamente simplista? Como ao mesmo tempo dizer que a relação existe mas não vê-la como relação direta?

Há várias teorias de como se compreender a ficção e de como devemos ou não fazer a relação com o real. Seguindo o livro Teoria da literatura em suas fontes, de Luiz Costa Lima, podemos ver alguns desses modos de analisar um texto de ficção e de relacioná-lo com a realidade.

Não iremos aprofundar esse tema - o que nos faria fugir de nosso assunto mas podemos ver, de modo bastante geral, que enquanto alguns dão mais importância à lingüistíca, à sistematização do texto (a Estilística, o New Criticism, o Estruturalismo), outros consideram mais os aspectos "externos" da obra (a análise sociológica, a estética da recepção). Sem ter a pretensão de dar conta de todas essas escolas e das divergências e semelhanças entre elas, e sem tomar uma posição totalmente definida de qual dessas escolas seguiremos (para dizer isso, teríamos de saber mais o que cada uma postula, quais as variações entre um autor e outro dentro da mesma escola - conhecimento esse que nos faria sair bastante de nosso foco no doutorado), ao menos indicaremos que pensamos estar mais próximos, em nosso modo de tentar compreender os romances de Sartre e Malraux, da análise sociológica e da estética da recepção, pois ambas levam em consideração a sociedade da qual surge o romance e à qual ele se dirige.

Da estética da recepção, tentaremos seguir um pouco do que Jauss fala em $O$ texto poético na mudança de horizonte de leitura ${ }^{27}$ : para ele, é necessário seguir três horizontes de leitura: a primeira seria a percepção estética - uma leitura feita passo a passo, pensando no significado das palavras, fazendo perguntas muitas vezes ingênuas mas necessárias. Esse seria o primeiro passo de aproximação: seguir o texto palavra a palavra, linha a linha, questionando quais seriam os significados, as referências, o sentido. E quando a leitura se completa, então surge o segundo horizonte: a interpretação retrospectiva, que seria uma segunda leitura, com muitas das perguntas já respondidas, com um direcionamento maior, dado porque o texto (poema, romance) já foi lido por completo, porque já sabemos o que virá a seguir, o que acontecerá com

${ }^{27}$ Cf. LIMA, L. Teoria da Literatura em suas fontes 2. 
tal personagem, com qual palavra essa que aparece nesse momento se ligará no momento seguinte, qual a seqüência de imagens levantadas pelo poeta etc. A partir do momento em que uma leitura atenta foi feita, podemos voltar ao início do texto e relêlo com mais propriedade - e só nessa segunda leitura a interpretação se dá, só aqui é que podemos compreender quais são os temas, as problemáticas de cada texto e imagem.

E por fim, depois que o romance foi compreendido nele mesmo, primeiro de uma forma ingênua e rente, e depois de uma forma mais geral, apreendendo o sentido do que o autor do texto colocou; Jauss diz ser necessário um terceiro horizonte de leitura, a leitura histórica, como reconstrução do horizonte de expectativa, relacionando-o com outros textos e com a maneira como foi lido e recebido em sua época.

Levando em consideração esses três horizontes de leitura (a percepção estética, a interpretação retrospectiva e a leitura histórica) Jauss pensa melhor compreender a ficção. E são esses três aspectos que tomaremos como direcionamento em nossa tese: em primeiro lugar, faremos uma leitura atenta dos textos, acompanhando cada linha, cada página, levantando os temas, pensando nos significados. Depois dessa leitura bastante rente aos romances, mostraremos algumas das principais questões colocadas por Sartre e Malraux e o modo como eles as tratam. E por fim, na conclusão, faremos a relação dessas questões levantadas com o horizonte histórico no qual os romances estão inseridos.

E assim como a estética da recepção, ao menos no modo como Jauss a expõe em seu artigo, será considerada em minhas leituras de Sartre e Malraux, também a análise sociológica será levada em conta.

Para Lima ${ }^{28}$, mesmo que muitas vezes correndo o risco de subordinar a arte à sociedade, a análise sociológica (representada por Lukács, Goldmann, Auerbach, entre outros) tem o mérito de reconhecer que há uma grande distinção entre o livro e a sociedade. Mas no momento de estabelecer a relação entre elas, quase sempre cai-se numa passagem muito direta e subordina-se a obra à vida do autor ou às condições sociais. Mesmo que a intenção seja analisar a ficção como a refração individual que transpõe para o imaginário o instrumento social por excelência que é a linguagem,

${ }^{28}$ Cf. LIMA, L. Teoria da literatura em suas fontes. 
Lima pensa que os que tentam realizar essa análise sociológica não conseguem dar conta de ao mesmo tempo separar e juntar a ficção com a realidade.

Pensamos que é um problema com o qual teremos de lidar, já que nossa pretensão é realizar essa distinção e aproximação entre mundo narrado e mundo vivido, e se não conseguiremos resolvê-lo por completo, se não conseguiremos não cair em nenhum momento nessa armadilha de passar de um mundo a outro sem considerar totalmente as mediações necessárias, ao menos tentaremos atentar para esses percalços que podem aparecer, aos deslizes que podem surgir.

E para melhor vermos como é possível nosso intento, o de mostrar a separação e ao mesmo tempo a relação estreita entre mundo narrado e mundo vivido, tomaremos como exemplo os livros de Antônio Cândido. Em suas obras conseguimos ver, de modo claro e lúcido, como se pode ao mesmo tempo considerar a obra pela obra e nessa compreensão da própria obra ver o mundo vivido, a sociedade. Trabalho ideal que teremos como guia e mestre, e que sabemos, de antemão, ser impossível imitar. Mas ao menos que nos sirva como referência e que nos ajude nesse caminho tão cheio de pedras que é o tema da tese.

Como o próprio Antônio Cândido diz em seu livro O discurso e a cidade:

\footnotetext{
O meu propósito é fazer uma crítica integradora, capaz de mostrar (não apenas enunciar teoricamente, como é hábito) de que maneira a narrativa se constitui a partir de materiais não literários, manipulados a fim de se tornarem aspectos de uma organização estética regida pelas suas próprias leis, não as da natureza, da sociedade ou do ser (...). De fato, uma das ambições do crítico é mostrar como o recado do escritor se constrói a partir do mundo, mas gera um mundo novo, cujas leis fazem sentir melhor a realidade originária ${ }^{29}$.
}

Por meio da nova realidade criada, podemos compreender e sentir melhor o mundo vivido: eis o poder da ficção, nomeadora e deformadora do real, e uma deformação de tal modo feita que a imagem se torna mais nítida, mais lúcida, mais crítica.

É esse o trabalho que um crítico deve realizar: entrever na obra um mundo novo, um mundo imaginário que tem vida própria, e que, em si mesmo, nos faz melhor compreender o mundo vivido. E para realizar esse trabalho, Antônio Cândido

${ }^{29}$ CÂNDIDO, A. O discurso e a cidade - p. 9. 
não parte do mundo (da vida do escritor, das condições da época em que o texto literário foi escrito), mas da própria obra: "Embora filha do mundo, a obra é um mundo, e que convém antes de tudo pesquisar nela mesma as razões que a sustêm como tal" ${ }^{30}$.

A obra deve ser considerada nela mesma, é ela que deve ser compreendida, por suas palavras, por sua magia, por suas temáticas e imagens - não se deve subordinar a obra à sociedade da qual surge e à qual se dirige. Mas isso não significa, para Antônio Cândido, que a realidade não importa, que a obra de arte é alheia e totalmente abstrata: ela se dá nesse mundo em que vivemos e ele, de um certo e outro modo, está presente em qualquer arte. Explicar a obra pelo social ou considerar a arte pela arte são duas opções extremadas, que não dão conta da imbricação entre obra e realidade:

Hoje sabemos que a integridade da obra não permite adotar nenhuma dessas visões dissociadas; e que só a podemos entender fundindo texto e contexto numa interpretação dialeticamente íntegra, em que tanto o velho ponto de vista que explicava pelos fatores externos, quanto o outro, norteado pela convicção de que a estrutura é virtualmente independente, se combinam como momentos necessários do processo interpretativo. Sabemos, ainda, que o externo (no caso, o social) importa, não como causa, nem como significado, mas como elemento que desempenha um certo papel na constituição da estrutura, tornando-se, portanto, interno ${ }^{31}$.

E este será nosso desafio: partir dos horizontes de leituras indicados por Jauss e tentar estabelecer uma relação entre ficção e realidade, estética e ética, que consiga ao mesmo tempo mostrar a deformação que o imaginário realiza na realidade e o quanto essa deformação nos possibilita ter uma imagem mais lúcida e precisa do real. Por meio de uma leitura atenta e rente dos textos de Sartre e Malraux, tentaremos indicar que a realidade está presente nos romances (e que por isso é possível entrever uma ética da estética), não como causa ou significado, mas como estrutura interna da obra - o que Antônio Cândido tão bem mostra.

Mas longe de termos a sabedoria e lucidez de Antônio Cândido, nos contentaremos em indicar como essa relação entre estética e ética pode ser vista nos romances desses dois escritores franceses.

Às obras!

\footnotetext{
${ }^{30}$ IBIDEM - p. 105.

${ }^{31}$ IDEM. Literatura e sociedade - p. 4.
} 


\section{CAPÍTULO 1}

\section{OS CONTOS DE JUVENTUDE}
a) Os contos de Malraux
b) Os contos de Sartre 


\section{OS CONTOS DE JUVENTUDE}

A literatura quase sempre esteve presente na vida de Malraux e Sartre, mesmo quando ambos se ocupavam com outras questões, seja a política, as guerras, a filosofia ou o poder. A ficção sempre foi uma opção e um exercício real para ambos, e pensamos que uma análise comparativa de seus livros, tanto no que diz respeito à forma quanto ao conteúdo, é fundamental para compreendermos qual a função da arte para cada um (ao que chegaremos ao comparar as obras com os textos mais teóricos) e qual a maneira com que essa se relaciona com a ética (e se se deve fazer tal relação).

Para tanto, iniciaremos nosso trabalho justamente pelo início das obras de cada um, pelos textos considerados de "juventude", anteriores ao primeiro livro publicado e considerado pela crítica (Les Conquérants, no caso de Malraux, e La Nausée, no caso de Sartre). Nesses textos considerados ainda em maturação pode-se ver mais claramente quais são as influências que cada um deles sofre e também verificar, de um modo mais "cru”, menos sofisticado, qual a concepção de ficção que eles assumem.

Embora Malraux seja mais velho que Sartre (nasceu em 1901, enquanto Sartre nasceu em 1905) e reconhecido literariamente antes (seu sucesso se inicia com a publicação de Les Conquérants em 1928, enquanto Sartre só terá reconhecimento literário na década de 30, com a publicação de La Nausée), não há uma diferença significativa em relação aos primeiros escritos de ambos. Tanto os textos de Malraux que serão aqui analisados (Lunes en Papier, Écrit pour une idole à trompe e La tentation de l'Occident) quanto os textos de Sartre (Jésus la Chouette, L'ange du morbide e outros) foram, em sua maioria, publicados no início da década de 20 . A diferença maior ocorre no final da década de 20, quando Malraux já publicara livros de impacto após sua volta da Indochina (Les conquérants, La Condition Humaine), e Sartre ainda continuava a publicar contos e fragmentos em revistas, sem alcançar nenhum reconhecimento importante. Mas no início da década de 20 ambos estavam começando suas carreiras literárias, o que nos possibilita, então, aproximar os textos ao menos em relação ao contexto histórico. 
Se a época é a mesma, o conteúdo, no entanto, não poderia ser mais antagônico. Para quem conhece os textos principais de Sartre e Malraux, próximos nos temas de guerra e situações extremas, e mesmo na forma de narração, tentando eliminar o narrador onisciente, é surpreendente ver que um começa de forma oposta ao outro. E quem mais surpreende é Malraux, um escritor que ficou tão conhecido por livros que mostram homens em conflitos sociais (guerra na Indochina, guerra na Espanha) e que começou a escrever sobre balões que se transformam em pecados e serpente que aparece na forma da Clave de Sol. Nada mais distante dos livros que escreverá depois.

Já Sartre se mostra, ao menos nesse âmbito e à primeira vista, mais coerente: desde seus primeiros escritos temos uma crítica à sociedade burguesa e a seus valores e uma ironia que atinge até mesmo o personagem principal, no início quase sempre o alter-ego do autor. Se Sartre é quem mais é acusado de ser incoerente consigo mesmo, ao menos nesse campo literário pode-se dizer (talvez malgrado o próprio filósofo) que Malraux parece ser mais instável, menos fiel às suas concepções iniciais do que é a literatura e qual sua função, ao menos em relação à forma da narração.

Tentaremos mostrar, nesse primeiro momento, que, mesmo que as obras principais e mais consideradas possam ser aproximadas e semelhantes, o início literário de cada autor é oposto, e essa oposição indica não somente o que cada um compreende por obra de arte mas também em como e se a ficção se relaciona com o real. O que mais se destaca no início são as diferenças, e podemos, para começar, destacar as mais radicais, antes de fazermos uma análise pormenorizada de cada conto.

O imaginário, o conteúdo da ficção apresentado por ambos, é diferente em grau máximo: enquanto o mundo irreal que lemos nas obras de Malraux não se parece com o mundo cotidiano, o mundo irreal de Sartre é semelhante ao mundo real. Com isso não pretendemos dizer que a narração precisa ser realista para fazer referência à realidade. Há formas de narrativa como a metáfora e o fantástico que, sem fazer referência direta ao vivido, ilumina-o com uma luz mais clara e límpida que uma descrição que se pretende "fiel" (basta ver o realismo fantástico da literatura hispanoamericana para compreender o quanto a fantasia pode nos fazer melhor compreender as imagens e questões de nosso mundo). 
Mas a deformação que toda ficção exerce sobre o real é vista de modo mais forte nos contos de Malraux que nos de Sartre. E é apenas a isso que fazemos referência quando dissemos que o mundo irreal de Malraux não se parece com o mundo cotidiano enquanto o mundo irreal de Sartre nos é mais semelhante: trata-se apenas de assinalar que as histórias narradas por Malraux não encontram ecos diretos no vivido, enquanto as histórias de Sartre fazem essa relação da forma mais direta e explícita possível. O primeiro inicia seu Lunes en Papier descrevendo que as luas têm inveja dos balões, os quais se transformam em pecados: aqui nem o cenário nem os personagens têm uma aproximação direta com o real, tudo é "irreal" demais, "fantástico". E o mesmo ocorre em seu outro conto que será analisado aqui - Écrit pour une idole à trompe - embora a narração seja em primeira pessoa (e se difira portanto do outro conto), os personagens também são ou irreais demais ou ao menos estão confrontados a situações por demais irreais, absurdas, como a da serpente que come mulheres e é apaixonada por música.

Nos textos iniciais de Malraux, o cenário e os personagens estão próximos do cubismo literário, das formas geométricas, da loucura calculada e ordenada. Já nos textos iniciais de Sartre ocorre o contrário: de todos os que serão analisados (L'ange du morbide, Jésus la chouette, La semence et le scaphandre, Une défaite, Er l'arménien), apenas este último tem um cenário mitológico e irreal - todos os outros textos descrevem pessoas comuns em cenários comuns, cidades, casas, bares e escolas normais, lugares vivenciados por Sartre.

Assim, ao menos por esses textos que foram lidos, podemos dizer que o irreal apresentado por Malraux mostra uma distorção maior do real do que o apresentado por Sartre: enquanto os contos do primeiro nos aparece como um convite à fuga, ao menos a um desligamento momentâneo com o que existe, os contos de Sartre não nos permitem facilmente esse exercício, já que seu irreal não distorce muito o real.

Mas as diferenças dos contos iniciais de Sartre e Malraux não se dão apenas em relação à forma, às descrições, mas também em relação ao conteúdo. Seja retratado de forma alegórica ou cotidiana, ambos insistem em alguns temas: a questão dos valores, da moral, por exemplo, está presente na obra dos dois autores, o que mostra que essa problemática os preocupa desde cedo. No entanto, mesmo falando da mesma questão, eles a tratam de maneira muito diferente: para Malraux a questão é a perda dos valores - sem Deus, com uma Morte e Diabo desinteressados e 
desanimados, atos extravagantes nascem e é necessário buscar uma nova noção de homem; para Sartre, a questão é a crítica dos valores burgueses, é a ironia para com seus próprios valores. Enquanto um coloca a problemática metafísica de buscar os valores e uma nova noção de homem, o outro coloca essa questão no plano existencial, crítico.

E nessa busca por novos valores e mesmo na crítica aos valores atuais, a aventura tem um papel essencial. Os personagens de Malraux sempre estão em busca de algum fim e para isso fazem aventuras, viagens a um mundo desconhecido, enfrentam desafios e normalmente vencem todos os preparativos, as armadilhas e quando enfim chegam próximo do fim desejado, já não se lembram mais qual era esse fim, esse desejo. A aventura, nos textos de Malraux, é uma necessidade frustrada, é $o$ meio para se alcançar o fim desejado (no caso de La tentation de l'Occident, uma nova noção de homem) e a impossibilidade de alcançá-lo. A aventura é necessária mas sempre vã... Já os personagens de Sartre também buscam uma aventura, mas é uma aventura relacionada ao modo de vida burguês que eles levam e não uma necessidade. Ao narrar as aventuras e fracassos de seus personagens, Sartre parece relatar uma ambição burguesa que foi sua própria ambição mas da qual é necessário zombar. Mesmo identificando-se com o personagem, percebemos uma distância entre o narrador e os personagens, e uma ironia em relação às aventuras dos personagens está sempre presente.

É certo que nos dois autores a aventura sempre fracassa, mas mesmo esse fracasso adquire dimensões diferentes para ambos: se em Malraux o fracasso mostra a impossibilidade de encontrar essa nova noção de homem e sempre vem acompanhado do choro, da paralisia, em Sartre o fracasso não se mostra tão fracasso assim: embora mostre também a impossibilidade de alcançar o que se quer (talvez por ser ideal, irreal demais), há um quem perde ganha esboçado desde já - os personagens sofrem, mas acabam por vencer graças ao fracasso, compensação essa que não existe para os personagens de Malraux, ao menos nos contos de juventude.

Tentaremos mostrar, pois, que há divergências importantes entre o jovem Sartre e o jovem Malraux no que diz respeito à concepção estética, e faremos isso através de uma análise pormenorizada de alguns textos de ambos tanto em relação à forma (à escolha dos personagens, às imagens e modo de narração, cenário) quanto em relação ao conteúdo (valores, aventuras, fracasso), de modo a mostrar que essa 
diferença na concepção de arte envolve também uma diferença ética (ao menos, nesses primeiros textos, em relação à perda dos valores).

Mesmo que os textos principais Sartre e Malraux se assemelhem, tentaremos mostrar que o início literário de um é oposto ao do outro; e para isso nos será necessário uma análise compreensiva de suas obras, o que começaremos a fazer agora. 


\section{A) Os Contos de Juventude de Malraux}

\section{Lunes en Papier}

Malraux publica seu primeiro escrito, Lunes en Papier, em 1920, na revista Action, e o dedica a Max Jacob, um pintor e escritor cubista.

Nessa época, o escritor já era conhecido nos meios literários, não pelo que escrevia, mas pelo que organizava. Malraux trabalhava há mais de um ano como agente e/ou diretor literário para alguns editores, seja procurando livros raros em buquinistas seja organizando pequenas edições de obras de Laforgne, "un poète qui, comme lui, alors, unissait l'ironie au pessimisme, la désinvolture au sérieux de la pensée; précurseur, en outre, de ce Cubisme littéraire qui retenait beaucoup André ${ }^{\prime 32}$. E é trabalhando com esses editores que Malraux entra em contato com escritores e pintores que muito admirava, como Max Jacob e Picasso. Em 1920, com o intermédio de Jacob, Malraux entra em contato com o grupo da revista Action, na qual publicavam, entre outros, Cendrars, Aragons, Paul Eluard e também desenhos e pinturas de Braque e Picasso.

Os amigos que Malraux tinha e o meio em que vivia já pode começar a nos indicar uma certa direção de suas obras. Editar livros de Laforgne, ser amigo (de) e admirar Max Jacob, escritor e pintor ligado ao Cubismo, gostar de Picasso, Cendrars... tudo isso nos revela uma relação com o Cubismo, uma linha que se mostrava ao mesmo tempo como exercício livre de imaginação e como extremo rigor. Tanto Picasso como Max Jacob são inimigos da improvisação e criam absolutamente; e é essa fantasia cheia de ordem que Malraux admira nesses artistas e tenta recriar em seu Lunes en Papier. Ainda segundo Vandegans (autor em que nos baseamos para obter informações sobre o meio que Malraux freqüentava na época de seus primeiros escritos), Malraux apreciava em Max Jacob "un maître incomparable de nonconformisme, doté d'une inépuisable imagination, mais aussi un artiste épris de conscience et de perfection technique (...). Liquidateur ironique du passé, créateur d'avenir, défenseur tout en même temps de l'invention et des disciplines, Max avait beaucoup pour plaire au premier Malraux ${ }^{\natural 33}$. O cubismo que Picasso e Jacob exercem é um cubismo com liberdade e ao mesmo tempo com regras definidas, com criação absoluta e técnica, e é esse paradoxo que tanto atrai Malraux.

\footnotetext{
${ }^{32}$ VANDEGANS. La jeunesse littéraire d'André Malraux - p. 22.

${ }^{33}$ IBIDEM - p. 42.
} 
Lunes en Papier foi então publicado em 1920, na revista Action, e dedicada a Max Jacob, homem para quem "une oeuvre d'art [...] vaut par elle-même et non par les confrontations qu'on peut faire avec la réalité ${ }^{\prime 34}$, o que nos indica que ao menos a primeira tendência de Malraux em relação à arte se inclina mais a um fantástico, a uma criação absoluta que a um certo realismo ou referência ao real. Se o texto é dedicado a Jacob é porque este exerce uma influência sobre o autor, e essa influência se deve justamente ao fantástico técnico (não o fantástico do surrealismo, dos associacionismos ilógicos e totalmente sonhados, mas de um fantástico que só existe junto a uma técnica precisa e fechada).

Mas não devemos aprofundar essas influências diretas e indiretas, já que nossa intenção não é realizar uma leitura genética dos romances. É preciso compreender as obras de juventude nelas mesmas para então confrontá-las com as noções de estética que Malraux deixa entrever em seus textos mais teóricos e só então analisar qual o papel que sua arte parece exercer no mundo. E do que trata esse conto de Malraux?

É o próprio autor que afirma falar de lutas pouco conhecidas dos homens e de uma viagem entre objetos familiares mas estranhos.

Essa apresentação já nos dá algumas indicações de como Malraux entende seu próprio livro: ele falará de lutas, de conflitos que são quase desconhecidos dos homens e de uma viagem entre objetos que se são familiares, nem por isso são comuns: eles se mostram, nesse conto, de modo estranho. O primeiro termo de cada descrição nos aproxima do real: luta, viagem e objetos familiares - tudo inicialmente nos leva a crer que se trata de assuntos, objetos e ações cotidianas, com as quais convivemos no mundo real. Mas o segundo termo dessa descrição faz uma ressalva (ampliando a concepção estética, de acordo com o ponto de vista de Malraux): trata-se de uma luta, mas de uma luta pouco conhecida, são objetos familiares, mas familiares estranhos. Se no início o real é que aparece na ficção, logo depois vemos que não é o real propriamente dito: as ações e objetos podem parecer familiares, mas são na verdade pouco conhecidos e estranhos.

Com essa descrição Malraux parece colocar a ficção como algo que, se não é possível isolar totalmente do real é, porém, estranho e pouco conhecido. A arte não retrata e nem pretende compreender o real, mas também não é, inversamente, um abstrato absoluto totalmente subjetivo.

\footnotetext{
${ }^{34}$ GUIETTE. La vie de Max Jacob - p. 162.
} 
Assim, o que Malraux nos propõe em Lunes en Papier é uma aventura cheia de ações, viagens e lutas, na qual elementos reais aparecem mas de modo estranhado, diferente do aspecto e lógica que se espera dele. É uma aventura fantástica e o vínculo que estabelece com o real é devido apenas a uma familiaridade que deve ser, no entanto, quebrada, chocada com o uso da fantasia ordenada. Lunes en Papier, como nos adverte o autor, não é um puro devaneio, nem um simples relato do real. O irreal, a ficção, a arte devem ser desconhecidos, estranhos, fantásticos, mesmo que só contenham elementos reais ${ }^{35}$.

É assim com os personagens: “familiarmente" inanimados, adquirem vida logo no início da fíç̧ão, tornando-se estranhos, desconhecidos: luas, balões e um animal (gato), que é o gênio do lago, tudo descrito com forma geométrica: tanto o cenário quanto esses personagens sempre são caracterizados por alguma forma (balões, cônicas, cubos, esferas, etc).

A lua muda de cor, seus dentes (ou notas) caem quando ri: estamos diante do irreal, do desconhecido, daquele "objeto familiar mas estranho", de uma lua que tem várias cores, dentes, que age, que ri e que tem inveja da harmonia e elegância dos balões que estão sobre o lago.

E essa lua, tão estranha lua, com inveja dos balões que vê, tem desejo de matálos, obrigando, assim, os balões a agir. A ação dos balões não se deve a uma decisão totalmente livre: é a inveja do outro (a lua), o perigo que eles correm de serem mortos que os fazem agir. E qual a ação praticada por eles? A invasão de um palácio, que parece forte e seguro. Mas essa ação não é feita por meio de armas e força: elas seriam inúteis para conquistar um palácio. Apenas com a leitura de uma peça ${ }^{36}$, ou melhor, apenas quando a leitura da peça termina, quando a palavra "Rideau" é dita é que a invasão se torna possível, e isso porque o palácio dorme. Estranha função do teatro essa a de fazer com que o palácio durma ao ouvi-lo, feche os olhos para o real e nem perceba que está sendo invadindo. Estaríamos diante de uma ficção que teria justamente a função de nos afastar do real, de se contrapor a ele de tal modo que não mais o reconheçamos? A arte, no início do conto, no primeiro momento em que aparece, ao menos essa arte 'política', parece ser rival do real, o lugar para "dormir" e

\footnotetext{
${ }^{35}$ Além da dedicatória a Max Jacob e da curta descrição, Malraux faz uma advertência ao leitor: a de que não há nenhum símbolo no livro. Não nos ateremos a essa questão, mas apenas deixamos indicado que, segundo a edição de Oeuvres Complètes da Gallimard, grande parte dos comentadores tende a ver nessa advertência uma ironia, uma interdição que deve ser transgredida, pois o conto é permeado por símbolos. ${ }^{36}$ pièce à thèse de son cru: peça que desenvolve opiniões políticas, filosóficas ou religiosas.
} 
não reconhecer mais o que acontece realmente, assim como faz o palácio diante da leitura da peça.

Mas essa "vitória" dos balões não dura (a arte é efêmera): logo o gênio do lago, o gato, acorda, vê que os balões tinham fugido e resolve capturá-los. Há uma nova luta, um confronto, o qual novamente não é realizado por armas e força: agora são a curiosidade e a bebida as armas utilizadas pelo gato. Esse animal coloca um barril perto dos balões, que percebem o odor agradável e ousam experimentar, e quando vêem que bebem champagne, todos se precipitam sobre o barril (alguns balões morrem nessa confusão), e bêbados, dormem.

É a bebida, a artimanha (assim como foi o teatro) e não a força que ganha a luta pouco conhecida dos homens. Essas aventuras, e elas se repetirão em todo o conto, são realizadas pela imaginação e é sua astúcia que garante a vitória. Mas que tipo de vitória encontramos até aqui?

Os balões conseguem invadir o palácio mas logo se interessam pelo barril, se “entediam" com a vitória que tiveram. E o mesmo ocorre com o gato, o gênio do lago: ele faz os balões dormirem, aparece e os prende, desejando que esses soltem a língua, o que, no entanto, não ocorre. "Le chat a donc manqué sa vie. Sa passion l'a perdu. Et de se prendre à son tour, au bout du chapelet, les bras en croix. Cette fois, tous les ballons exhibent leur langue et le chat aussi, la sienne, 'une langue victorieuse qui sembla prétendre à frapper les autres mais retomba, flasque, comme si un coup d'épingle l'avait crevée'",37. Mesmo quando enfim consegue fazer com que os balões mostrem a língua (ao admitir sua derrota), isso já não tem mais importância. As aventuras são sempre satisfeitas, quem as faz sempre vence, mas essa vitória traz consigo a apatia, o desinteresse. O gato vence, captura, prende os balões e os faz mostrarem a língua; mas essa grande vitória - desejada e buscada - se frustra no momento mesmo em que é alcançada.

Alguns desses balões presos pelo gênio do lago se transformam em flores e frutos e de um desses frutos saem nove personagens, sete brancos e dois vermelhos. Os sete brancos são os Pecados, mas dois deles (os menores: a Inveja e a Avareza) explodem ao serem liberados. Temos então cinco pecados e dois personagens vermelhos que, antes de serem "alma de balão", eram o senhor do vidro e músico. Há um pequeno diálogo entre esses personagens, com o Orgulho estabelecendo a

${ }^{37}$ VANDEGANS. La jeunesse littéraire d'André Malraux - pp. 97- 98. 
comunicação entre os Pecados e os "homens". Essa é a primeira vez que o narrador deixa seus personagens falarem por si próprios, mas mesmo aqui percebe-se sua presença.

Após as apresentações, o Orgulho propõe que os dois personagens brancos se tornem os dois pecados que tinham explodido, e eles aceitam, mais por tédio e indiferença que por ter algum interesse nessa transformação. Eles deixam de serem vermelhos e se tornam brancos, como os outros pecados. Todos transformados em Pecados, é a vez do Orgulho perguntar aos novos personagens brancos se eles conhecem Deus, como se isso fosse um conhecimento indispensável para quem deseja ser Pecado. O músico responde que Deus é um pouco vulgar, enquanto o mestre do vidro responde que isso é natural, já que ele freqüenta muita gente; mas é ao Orgulho que cabe revelar a grande questão moral que deve ser enfrentada e resolvida por eles: Deus está velho e se tornou inconsciente, de tal modo que Satã tomou seu lugar e Deus não percebeu. O que temos é um Deus impotente e inconsciente, que nem percebeu sua derrota. Assim como o palácio dormia ao ser invadido e os balões dormiam bêbados ao serem presos, Deus dormia quando foi substituído por Satã: a vitória deixa de ter interesse quando é alcançada, mas a derrota também parece não ter valor nenhum. E talvez seja justamente a esclerose de Deus que tenha permitido isso Deus não está morto, mas sua vida já não interessa nem mesmo a ele - e essa constatação é mais angustiante que a própria morte.

Mas se Satã tomou o lugar de Deus, é possível, então, tomar o lugar de Satã, e é isso que o Orgulho sugere: uma aventura que os fariam se colocar no lugar que antes era ocupado por Deus e que agora o é por Satã. No entanto, Satã tem uma forte aliada: a Morte, a qual é necessário enfrentar antes de chegar a Satã. Para tomar seu lugar, é preciso antes matar a Morte, mas quando o Orgulho anuncia essa tarefa, a Morte "acorda" e "age", vê-se constrangida a lutar contra os Pecados. Ela transforma o cenário (a luz some) e faz corações serem disparados contra os Pecados, que logo percebem ser fácil explodi-los (ainda mais com a ajuda de vidros, feitos pelo novo Pecado). Vencido esse primeiro ataque da Morte, os Pecados estão prontos para irem até o Império da Morte, até o Royaume-Farfelu.

A própria palavra farfelu nos indica o caminho que Malraux pretende dar a seu conto: o reino da Morte, assim como toda sua obra, é o reino do farfelu, do que é um pouco louco, bizarro. Segundo o dicionário Le Robert, essa palavra, usada no séc. XVI por Rabelais no sentido de gros, dodu (grosso, grosseiro), sinônimo de futilité, 
foi "ressuscitada" no séc. XX por Malraux com esse novo sentido de fantasia, de algo que é um pouco bizarro, não é lógico - e o autor chegará, em seu livro Antimémoires, a classificar o gênero mesmo de seus contos como farfelu.

E no caminho, já perto do Royaume-Farfelu, os Pecados resolvem se abrigar em um albergue para passar a noite. Lá há um novo confronto: a Morte envia "bigotphones" 38 para cantar canções estúpidas e fazer os Pecados fugirem ou ficarem loucos. Se o primeiro ataque foi físico, esse segundo mostra ter as mesmas características das outras lutas (o uso do teatro e da bebida): é através da música que a Morte pretende ganhar o combate contra os Pecados. Mas não basta ter fantasia: é preciso ter técnica também, e é o antigo músico (agora Pecado) que revela a falta de harmonia nas músicas e consegue hipnotizar os "bigotphones" e prendê-los através da própria música. O fantástico é necessário (um ataque real, sem uso da imaginação, está fadado ao fracasso), mas não é suficiente (no embate entre dois fantásticos, entre a mesma arte - no caso, a música - ganha aquele que alia à ficção uma técnica e uma harmonia). Os Pecados, através dos conhecimentos do músico, ganham mais uma luta e fogem do albergue, indo agora direto até o Império da Morte.

E na cidade-farfelu há festa: a Morte, rainha, está doente e espera ser tratada pelo melhor médico, o qual vai atendê-la e se surpreende com os ossos de sua doente: ao invés de vértebras de osso, há alumínio, que é mais prático, leve e moderno (é assim, ao menos, que a Morte justifica a mudança: "Puis, je dois marcher avec le Progrès. Tout devenait mécanique, métallique, brillant; le caractère de ma beauté restait gothique: je n'étais plus à la mode" ${ }^{, 39}$ ). $\mathrm{O}$ médico diz que a doença é grave $\mathrm{e}$ que a Morte poderia ficar calva, o que a faz se horrorizar, mas que o tratamento era fácil: bastava alguns banhos em um líquido.

Essa Morte apresentada por Malraux é elegante e vaidosa: vestida de smoking, preocupada com a moda e a beleza (ela deve se adequar ao tempo para ser atraente), e horrorizada com a idéia de ficar calva... Morte frágil demais para seu papel, dependente demais do tempo para estar ao lado de Satã no lugar de Deus, vaidosa demais para ser levada a sério.

E é óbvio que, diante do "perigo" de sua doença e do "risco" de ficar calva, a Morte aceita ser tratada pelo médico. E no momento em que esse vai preparar o

\footnotetext{
${ }^{38}$ Palavra criada por Malraux, que tem o sentido de sons, vitrola "fervorosa", "crente" (em sentido pejorativo).

39 MALRAUX. "Lunes en Papier" In Oeuvres Complètes - p. 22.
} 
banho, o narrador nos revela que ele é o Orgulho. Junto com os outros Pecados, ele prepara um banho de ácido para dissolver o esqueleto de alumínio e assim matar a Morte. Esta volta e entra no banho, quando então lhe dizem que ela está sendo envenenada e que foi vencida. Diante dessa afirmação, a Morte ainda consegue corrigir o que foi dito, dizendo que estava corroída e não envenenada, com muita tranqüilidade e apatia. Ao invés de sair desse banho no qual sabe que morrerá, a Morte continua a se banhar e se aceita, dizendo-se cansada desse mundo: "Le monde - inutile de baîller, je serai bientôt morte - ne nous est supportable que grâce à l'habitude que nous avons de le supporter. On nous l'impose quand nous sommes trop jeunes pour nous défendre et ensuite..." 40 .

A Morte aceita a derrota com indiferença ou mesmo desejo, do mesmo modo como o Palácio e os Balões dormiam e nem notaram suas derrotas. A derrota, nesse texto de Malraux, não traz consigo nenhuma revolta: ela simplesmente é aceita de modo indiferente, com resignação.

E se a Morte é derrotada, os Pecados vencem. E será que dessa vez a Vitória é enfim reconhecida e desfrutada? Ou, como das outras vezes, ela é efêmera e nada significa?

Esse combate entre os Pecados e a Morte foi longo: esta ataca duas vezes durante o caminho e é vencida; e quando os Pecados chegam ao Royaume-Farfelu, são eles que atacam e vencem, definitivamente (tanto que essa terceira parte do conto se chama Vitória). Os Pecados tinham um objetivo, que era ocupar o lugar do Satã, e para isso tinham que matar antes sua aliada: a Morte. E após viagens e lutas, os Pecados alcançam seu objetivo: a Morte está morta e agora eles estão prontos para substituir Satã no lugar que era de Deus.

Tudo parece levar a uma Vitória certa, ao Êxito, mas eles não sabem mais o que fazer. "Le visage morne, ils se mettent à pleurer. 'Pourquoi avaient-ils tué la Mort? Ils l'avaient tous oublié",41. Tão preocupados em matar a Morte que esqueceram por que a mataram: é esse o diagnóstico pessimista no final do conto. Pior que as outras vitórias, que mesmo com desânimo ou efêmeras se reconheciam como vitória, essa nem mesmo é reconhecida enquanto tal. Os Pecados, por não lembrarem o objetivo que justificaria o ato de matar a Morte, choram e não têm o que comemorar: a morte da Morte não foi uma Vitória, já que nem sabem mais porque

\footnotetext{
${ }^{40}$ IBIDEM - p. 24.

${ }^{41}$ IBIDEM - p. 25.
} 
fizeram isso - ela se torna, assim, um ato desesperado e sem justificativas, um fato diante do qual seus próprios autores só podem chorar e perder.

Parece-nos que não há, nesse conto de Malraux, nenhuma perspectiva para o Êxito: há sempre combates e lutas, mas é uma luta que traz uma derrota apática e indiferente e uma vitória desanimada e derrotada. A frustração é a garantia dessa luta necessária (ao menos o conto todo se dá em combates) e vã, seja na derrota seja na vitória, que nem pode ser chamada propriamente de vitória.

Temos, então, nesse primeiro conto de Malraux, Lunes en Papier, personagens que sempre se envolvem em lutas e aventuras, e quer ganhem ou percam, a sensação final é apatia e fracasso, frustração ${ }^{42}$.

Segundo Vandegans, os gestos são vãos e fracassados nesse livro justamente devido à perda da moral, dos valores: se Deus nem mesmo percebeu que Satã tomou seu lugar, e se é possível que os Pecados façam o mesmo, todos os atos perdem o sentido (e para esse autor, isso reflete o que o próprio Malraux sente de seu mundo):

La première esthétique de Malraux est déjà en relation avec une attitude métaphysique et éthique. Malraux apporte, en naissant, un vif sentiment de l'absurde, un pessimisme foncier. Lorsqu'il accède à la plénitude de la conscience, c'est pour découvrir un monde que Dieu a cessé d'orienter et dans lequel les valeurs de la civilisation occidentale achèvent de se désagréger (...). Ainsi, les convictions qui peuvent donner un sens à la vie ont disparu. L'homme se trouve seul devant lui-même, dans un monde privé de but. Il n'y éprouve que le sentiment de la vanité de tout geste ${ }^{43}$.

Desse mundo sem valores, no qual Deus está vivo mas esclerosado, no qual Satã pode tomar seu lugar sem que ninguém perceba, é preciso fugir, afastar-se enfim, é preciso lutar contra esse real. E a arte parece ser, para Malraux, a arma mais poderosa e propícia para enfrentar o real, justamente porque se opõe a ele por meio do fantástico - mesmo que não vença ou tenha uma vitória derrotada no fim, como Lunes en Papier parece mostrar o tempo todo.

\footnotetext{
${ }^{42}$ Pensamos que essa questão da luta e do fracasso final, assim como a questão moral da perda dos valores, relatada aqui por um Satã que toma o lugar de Deus sem que este perceba, são temas constantes nas obras de Malraux e aqui apenas começamos a esboçar o modo como o autor as vê. Mesmo em suas obras principais, embora não haja mais cenário cubista e personagens e elementos estranhos, as questões da luta e da perda da moral resistem, e serão, em cada livro, analisadas.

${ }^{43}$ VANDEGANS. La jeunesse littéraire d'André Malraux - p. 63.
} 
A arte, para o jovem Malraux de 18, 19 anos, parece ter o peso absurdo de lutar contra o absurdo do mundo real através da criação de outro absurdo.

C'est encore parce qu'il trouve le monde banal, insuffisant et sa représentation dépourvue de fondament que Malraux les compense en recourant à la fantasie et à certain fantastique. Un fantastique qui ne soit nullement d'une vision particulière du monde, ni ne prétend nous introduire au coeur d'un prétendu réel. Simplement il offre un jeu de possibles par quoi s'affirme la liberté de l'esprit en face de la perception courante, ce produit de l'habitude. Ce genre de fantastique procède de l'inquiétude, mais aussi bien de rêveries dépourvues de tout caractère angoissant; et son utilisation répond en bonne mesure au besoin de s'opposer au monde ${ }^{44}$.

O que o texto de Malraux nos deixa perceber, desde o início, é que o real pouco participa da arte, que, se aparece, como na peça com opiniões políticas lida no início pelos balões, é necessário estranhá-lo, torná-lo irreconhecível. A obra de arte deve se opor ao real por meio do estilo e do fantástico a fim de tentar encontrar uma nova noção de homem. Para o Malraux de Lunes en Papier, a importância da arte é enorme, e como vimos nos combates desse texto, é somente por meio do fantástico unido à harmonia, à técnica, que a arte tem a possibilidade de fazer o real dormir e ser invadido, de modo que não mais se reconheça como tal.

Essa concepção estética da arte como fuga do real, como rival e oposta a ele (questão essa que será tematizada em seus escritos tardios), está intimamente ligada a uma atitude ética, a saber: a de reencontrar, por meios que se opõem aos reais e concretos, uma noção de homem, os valores perdidos e desprezados após o descaso de Deus para com o mundo e consigo próprio. Se o real não possibilita mais nenhuma busca de uma moral, é necessário, então, buscá-la por outro meio, por um meio que se oponha ao anterior - e para Malraux, essa seria a função da arte.

Mas antes de continuar essa análise da relação da arte como oposição ao real com uma ética que se propõe como busca de uma nova moral para os homens, vejamos um outro conto de Malraux - Écrit pour une idole à trompe.

${ }^{44}$ IBIDEM - p. 117. 


\section{Écrit pour une idole à trompe}

Este segundo conto de Malraux, publicado de 1921 a 1924, é, na verdade, constituído por vários fragmentos (alguns publicados após a viagem de Malraux à Indochina), os quais nunca foram coletados e transformados pelo autor em um só texto. Três ou quatro fragmentos publicados em revistas diferentes, em anos diferentes; eis o que forma Écrit pour une idole à trompe, unificado por causa do narrador em primeira pessoa: Pompier.

Escritos de um a três anos após Lunes en Papier, não se pode observar muitas mudanças nesse texto do ainda jovem Malraux: a fantasia continua presente (embora um pouco mais nuançada), as lutas pouco conhecidas dos homens e os objetos familiares mas estranhos também aparecem constantemente nesses fragmentos - e o mesmo se dá em relação à moral (ou à falta dela), à vitória frustrada e à derrota desinteressada. A forma e o conteúdo desse conto apresentam muitas semelhanças com Lunes en Papier.

Mas agora não temos mais um conto completo, terminado: Écrit pour une idole à trompe é composto por quatro fragmentos (seguiremos aqui o texto estabelecido por Oeuvres Complètes e não por Vandegans, que não considera o último fragmento): Les hérissons apprivoisés, Journal d'un pompier du jeu de massacre, Écrit pour un ours en peluche e Lapins pneumatiques dans un jardin français.

Em "Les hérrisons apprivoisés" temos a história contada em primeira pessoa, por Pompier (diferentemente de Lunes en Papier, nesses textos veremos sempre um narrador-personagem). Ele e alguns amigos encontram-se em um albergue, no qual começam a ocorrer atos estranhos após a visita de um estrangeiro - o Charlatão.

Tudo era calmo nesse albergue em que se encontrava Pompier e os amigos até quando Charlatan aparece, vindo de Bhouzylle para passar um dia. O visitante estrangeiro declara aos habitantes do albergue que conhecera a Virtude, e que ela estava velha e feia. E é após essa declaração que atos extravagantes começam a acontecer, o que é, aliás, previsto por Charlatan (que oferece seu castelo como refúgio caso algo viesse a acontecer) e mesmo por Pompier, que diz ter medo "que la naissance d'actes extravagants ne soit bien prochaine" ${ }^{\mathrm{N}}$.

Do mesmo modo que vimos em Lunes en Papier, quando o Orgulho diz conhecer Deus, que estava velho e tão esclerosado a ponto de nem perceber que Satã

\footnotetext{
${ }^{45}$ MALRAUX. "Écrit pour une idole à trompe" In Oeuvres Complètes - p. 35.
} 
tinha tomado seu lugar, aqui é Charlatan quem diz conhecer a velha e feia Virtude. É o Orgulho e o Charlatão que revelam a velhice e caduquice dos "bons" valores. E após essa revelação o combate inicia.

Temos aqui a mesma questão da perda dos valores, da feiúra e velhice de Deus e da Virtude - mas se em Lunes en Papier Deus nem mesmo percebe que não tem mais poder e nada faz, ao menos aqui a Virtude ainda é lúcida e tenta agir, mas por uma ação que desde o começo está fadada ao fracasso: pelo fantástico sem nenhuma harmonia. Patos invadem o albergue para destrui-lo, mas a música encantada que os ciganos tocavam faz com que esses se apressem para entrar no albergue e se matem (morte semelhante a dos balões diante do barril de champagne, que se atropelavam para poder beber).

A Virtude, ao ter sua identidade revelada, ataca através do fantástico, mas novamente a harmonia, beleza e técnica da música impedem a vitória, salva Pompier e os amigos. Como em Lunes en Papier, a música harmônica vence, mas se no primeiro conto os Pecados confiam totalmente nessa vitória a ponto de seguirem para o Império da Morte, aqui ela já não inspira tanta confiança nos personagens.

Logo após a morte dos patos pelo encantamento da música, eles decidem fugir. "Cette ataque de la Vertu doit inciter le Pompier et ses amis à se refugier chez le Charlatan"46. Preparada a fuga, Pompier caminha até uma moita, até um aglomerado de árvores, de onde ele vê que marmitons (ajudantes de cozinha) entram na cozinha e descobrem que os amigos de Pompier queriam fugir. Com socos e golpes, fazem os amigos caírem no chão. Um incêndio começa e Pompier foge sem olhar para o albergue e para seus amigos que lá estavam.

Esse fragmento termina com a fuga de Pompier, que penetra no meio do mato, onde então se encontra com uma figura tímida e bêbada - o Diabo; encontro esse que será relatado no próximo fragmento - "Journal d'un Pompier du Jeu de Massacre”.

Como o próprio nome diz, trata-se de um diário de um "bombeiro" do "jeu du massacre", ou seja, do jogo em que se deve abater marionetes com balas. Seria então o Pompier que vimos no conto anterior não um homem real mas uma marionete? Nesse conto somos surpreendidos com a revelação de que esse homem também não é um homem conhecido dos homens: Pompier é uma marionete que faz parte de um jogo, que espera ser abatido por balas.

\footnotetext{
${ }^{46}$ VANDEGANS. La jeunesse littéraire d'André Malraux - p. 163.
} 
Não há, então, diferença entre o primeiro e o segundo conto de Malraux no que diz respeito ao aparecimento do personagem "homem": embora ele apareça nos dois contos, é sempre um homem que deixou de ser homem, que agora é balão ou marionete, caso de nosso personagem nesse conto, o Pompier, que foge do albergue e entra no meio de uma floresta, no meio da noite. Um tagarela surge então, mas tímido, calmo, bêbado, e anuncia que “tout s'en va parce qu'il n'y a plus de morale"47. É novamente anunciada a questão central desses contos de Malraux: a perda de uma moral, dos valores. O Pecado e agora o próprio Diabo diagnosticam a contemporaneidade como ausência e falta de valores. Pompier ouve com paciência e por isso ganha um presente do Diabo: um apito que, se soprado, fará sair dois demônios que o ajudarão em caso de dificuldade. Feito isso, o Diabo, indiferente e bêbado, dorme.

Sem moral, o que resta, mesmo ao Diabo, é dormir, ficar indiferente a tudo o que acontece. Mas Pompier prossegue sua aventura: fugindo do albergue quando este pegava fogo, atravessando uma floresta no meio da noite, e agora, no próximo fragmento, enfrentando um concurso de música para dominar a Clave de Sol.

Em "Écrit pour un ours en peluche", terceiro fragmento desse conto fantástico, Pompier descobre que haverá na cidade um concurso para eleger o melhor músico, aquele que enfrentará o grande desafio de enfeitiçar e matar a Clave de Sol, serpente que se enrola em forma de clave de sol e que, de tanto matar mulheres, levou a cidade a oferecer duzentas moças por ano para esse monstro, o qual apresentava, no entanto, um ponto fraco: era suscetível à música. E após essa descoberta, feita pelo serviço de espionagem da cidade, foi instaurado o concurso de melhor músico.

Pompier se inscreve no concurso buscando a glória: e no dia da apresentação, julgado pelos ouvintes e matemáticos (novamente a questão da harmonia e regra na arte é enfatizada), vence a disputa. Sua missão é então a de enfrentar a Clave de Sol, de ir até seu castelo e aprisioná-la. Já na porta do castelo, diz que irá preparar a serpente para receber o tributo anual e consegue entrar. Munido com um pequeno saxofone, Pompier começa a tocar e para sua surpresa, a Clave de Sol o beija, diz que o ama e é mulher (e que só gostava de mulheres porque fizera um curso de estética e aprendera a apreciar a beleza e delicadeza das mulheres). Diante desse monstro que logo se mostra mulher apaixonada e devotada, Pompier percebe que a vitória será

\footnotetext{
${ }^{47}$ MALRAUX. "Écrit pour une idole à trompe” In Oeuvres Complètes - p. 42.
} 
fácil, e finge amá-la para prendê-la. Após a sedução artística e física, Pompier aprisiona a Clave de Sol.

Vencida a batalha, agora é a vez de exibir a Vitória e obter a glória. É a hora de voltar para Bhouzylle e entrar triunfalmente. Barcos e multidões esperam Pompier com a Clave de Sol, que, ao entrar na cidade, dormia, indiferente. A derrota da serpente lhe é indiferente: ela dorme, tranqüila e nem mesmo vê que será decapitada a seguir.

Nesse mundo sem valores, todos dormem: o Diabo, que anuncia essa realidade, a Serpente que vai morrer e perde sua luta... e os que vencem não dormem, mas se frustram: após decapitarem a Clave de Sol, todos parecem mortos: "une heure après, une aurore artificielle d'un grand charme éclairait la ville, mais les visages des habitants que je rencontrais avaient la couleur de ceux des cadavres" ${ }^{\prime 4}$. Os que ganharam o combate, os que enfim derrotaram a Clave de Sol, logo se mostram como cadáveres: a vitória, embora buscada, parece nunca satisfazer, nunca completar aquele que a busca - a vitória, aqui, parece ser derrota, estabelece que o fim não é ela mas a própria luta. A aventura se mostra como ilusão: quem a faz busca vencer, mas quando vence volta a ter necessidade de uma nova aventura. E a aventura é tão necessária que Pompier, logo após capturar a Clave de Sol, sai em busca de novo combate, o qual será relatado no último fragmento, "Lapins Pneumatiques dans un jardin français".

Dois personagens - Jazz e Hyzz, talvez saídos do apito dado de presente pelo Diabo - surgem e propõem a Pompier levá-lo de surpresa ao novo quarto de Passoire (uma companheira do antigo albergue). Eles vão e lá descobrem que é necessário subir pela torre, quando então flechas começam a cair sobre eles: Jazz e Hyzz matam os combatentes, dando tempo a Pompier de chegar ao quarto, o qual se encontra vazio. Toda essa aventura em busca de Passoire se mostra também vã, assim como todas as outras relatadas em Écrit pour une idole à trompe e em Lunes en Papier. Pompier vence os combatentes, consegue se livrar das flechas, mas seu objetivo não é alcançado: a moça desejada está ausente, talvez nem habite mais naquele quarto. A frustração final é o que nos fica desse segundo conto de Malraux, assim como do primeiro.

\footnotetext{
${ }^{48}$ IBIDEM - p. 51.
} 
Podemos dizer, assim, que não há nenhuma mudança significativa entre Lunes en Papier e Écrit pour une idole à trompe. Para ambos os textos aquela descrição resumida do primeiro (que se trata de lutas pouco conhecidas dos homens e de uma viagem entre objetos familiares mas estranhos) pode ser aplicada. Embora o fantástico diminua um pouco (as cidades e os cenários são um pouco mais reais, assim como os personagens), ele ainda está presente. O mecanismo da fantasia, do pitoresco é comum a ambos os contos, mesmo se sua aplicação seja mais moderada no segundo. O que há é uma nuance do fantástico, da loucura (nuance essa que irá se acentuar cada vez mais nas obras de Malraux), mas são eles que dominam a estrutura desse segundo conto, com seus fatos extravagantes, encontros com Diabos e serpentes que amam música.

E não só a forma dos contos é semelhante como também o conteúdo: os temas narrados das lutas, da perda dos valores, da indiferença de Deus e do Diabo, as aventuras realizadas para alcançar a vitória, a vitória que se impõe como frustração, derrota, são os mesmos. Tanto em Lunes en Papier como em Écrit pour une idole à trompe Malraux enfatiza a grande questão da falta de uma moral (da perda da noção de homem) que traz, como conseqüência, a necessidade de confrontos, de lutas e aventuras, cujo resultado relatado é sempre uma vitória insuficiente, insatisfatória, fracassada.

Os problemas morais são centrais nesses dois escritos literários de Malraux, e pelos atos dos personagens, podemos dizer que os únicos meios de confrontá-los são a fantasia, a aventura, a arte, as quais devem ser, porém, regradas com uma certa harmonia e ordem. Para Malraux, a única maneira de obter uma vitória contra esse mundo sem valores é talvez, por meio da arte e da aventura, da fantasia aliada à harmonia, à ordem.

A arte e a aventura fantástica (presentes o tempo todo nesses dois contos) serão para Malraux as maneiras mais frutíferas de tentar alcançar essa nova noção de homem que tanto procura, e que só pode ser alcançada contra o real, contra esse mundo no qual os valores não mais existem e as pessoas (e Deus e o Diabo) são indiferentes a isso.

\section{La tentation de l'Occident}

Se entre a escrita de Lunes en Papier e de Écrit pour une idole à trompe havia pouca diferença temporal, o que pode ser visto pela semelhança dos temas e formas, 
para a publicação de La tentation de l'Occident transcorre um tempo maior e, principalmente, ocorre uma experiência que será marcante para o jovem Malraux.

Já quando publicava os últimos fragmentos do segundo conto, Malraux preparava sua viagem para a Indochina. Seja porque sua angústia perante o absurdo mundo ocidental e sua falta de valores aumentou a tal ponto que alguma ação concreta se tornou necessária (o que Vandegans justifica como sendo o motivo principal da viagem), seja porque encontrara um novo modo de ganhar dinheiro por meio de seu conhecimento de arte (assim como comprava livros raros nos buquinistas para revendê-los aos editores, assim como apostava na Bolsa que quebrara, agora seriam objetos de arte roubados dos templos abandonados que seriam vendidos para colecionadores), o que nos importa fundamentalmente aqui é que a viagem de Malraux se relaciona fortemente com as questões estéticas e morais apresentadas em seus romances.

É em 1923 que Malraux e sua mulher vão para a Indochina e, juntamente com Chevasson, fazem uma excursão para alguns templos abandonados. Lá, os amigos recolhem alguns objetos que tinham valor artístico. Mas na volta são inspecionados e as peças são encontradas, o que os leva a serem julgados pelo tribunal de Pnom-Penh e de Saigon, que acabam por condenar Malraux e Chevasson a 1 ano e 8 meses, respectivamente, de prisão, mas com sursis. Ambos voltam para a França, mas Malraux pouco tempo permanece em seu país: "Il aura donc quitté l'Indochine, en novembre 1924, avec le désir d'y revenir rapidement pour continuer de travailler à une entreprise de libération de l'homme nouveau" ${ }^{49}$. Alguns comentadores e mesmo Vandegans questionam se o desejo de Malraux ao voltar para a Indochina era ajudar e organizar uma ação coletiva e revolucionária, ou apenas satisfazer sua necessidade de ação e poder. O que hoje parece certo é que Malraux não teve, como se pretendia na época, um papel importante no processo revolucionário que se travava na Indochina. Ao menos pelo que se pode ser lido nos jornais "L'Indochine" e "L'Indochine enchaînée" (jornais dirigidos por Malraux, e segundo HARRIS. De L'Indochine au $R P F$ : une continuité politique), o que se propõe neles é mais uma conciliação e uma boa vivência com a França do que uma ruptura e revolução. Malraux fala em política de associação, de colaboração e se se posiciona contra o governador da Conchinchina é porque é contra o meio que este utiliza para tentar alcançar a ordem - pela força - e

\footnotetext{
${ }^{49}$ VANDEGANS. La jeunesse littéraire d'André Malraux - p. 241.
} 
não porque seja contra a presença e o domínio dos franceses na Indochina. Embora essa viagem seja vista como o ponto de partida do engajamento revolucionário político de Malraux, não se pode ver, segundo Harris e Vandegans, uma real ação revolucionária de nosso escritor. De acordo com o primeiro comentador, o jornal que Malraux publicava chegava a falar de uma reaproximação franco-anamita, e que "plutôt qu'une intention révolutionnaire il pourrait sembler que ce soit un nationalisme paternaliste français qui sous-tend le journalisme indochinois" ${ }^{~}$, .

Mas não é essa a imagem de Malraux logo após seu retorno à França. Visto como revolucionário, participante importante das questões sociais que se desenrolavam no Oriente, admirado por sua coragem e ousadia - é este Malraux que seus amigos vêem e é a ele que são pedidas opiniões sobre o que ocorria na Indochina e como seu olhar, agora diferente, via o próprio Ocidente. Logo após sua volta, Malraux começa a publicar textos que aparentemente em nada se parecem com os contos anteriores: é nessa época que os romances revolucionários são publicados.

Mas antes da publicação do romance, é uma ficção baseada em cartas sobre a visão do Oriente e do Ocidente que é publicada, e é o que analisaremos agora - $L a$ tentation de l'Occident, publicado no ano mesmo em que Malraux volta da Indochina, em 1926.

Esse texto é totalmente distinto dos anteriores. Não se trata mais aqui de contos nos quais a fantasia impera e os personagens e cenários são irreais, poucos conhecidos dos homens. Agora os dois personagens são humanos e os cenários também são semelhantes aos reais. O texto não é mais uma narração, mas sim um diálogo entre dois jovens, um francês que conhece a China e um chinês que viaja para a Europa. Na verdade, as cartas são quase todas de Ling, do chinês, que nelas conta suas impressões sobre a Europa, o modo de vida dos ocidentais, suas relações com a moral, a religião e a arte. Nesse texto temos o mesmo argumento utilizado pelos escritores-filósofos do séc. XVIII francês: para falar do próprio povo, de sua civilização e seus costumes, põe-se como personagem um viajante, alguém que conhece um outro modo de vida e que possa estranhar, ironizar e criticar o modo de vida tão conhecido dos europeus. Ling, o personagem chinês de La tentation de l'Occident, com seu olhar oriental, é capaz de revelar melhor o mundo contrário. E Malraux, através dessa técnica, mostra que o melhor modo de se conhecer uma

\footnotetext{
${ }^{50}$ HARRIS. De l'Indochine au RPF: une continuité politique (les romans d'André Malraux) - pp. 14 - 15.
} 
determinada civilização, mais que estudá-la a fundo, é compará-la com uma outra, oposta - assim como se pode conhecer melhor a arte européia comparando-a com os objetos estéticos dos templos abandonados da Indochina, o mesmo se dá com as civilizações.

Ling retrata, em suas cartas a A.D. (o francês que estava na China) sua visão da Europa, do continente no qual os habitantes pretendem transformar o mundo e no qual há "une barbarie attentivement ordonnée",51. O tempo todo Ling compara o homem ocidental que conhece em sua viagem com o homem oriental que é: a referência do viajante é seu próprio modo de viver, sua própria moral e arte. Há sempre um contraponto entre o ocidental e o oriental: enquanto o primeiro pensa transformar o mundo, o segundo pensa ser transformado por ele.

E se é Ling que tem uma certa predominância desde o início, se são as cartas dele que aparecem com maior freqüência, é o europeu que julga o julgamento do outro no final. É A.D. quem, no fim dessas correspondências escolhidas, comenta as impressões de Ling, concordando com o que este tinha visto - com a perda dos valores e a tentativa desesperada de encontrar algo: "Pour détruire Dieu, et après l'avoir détruit, l'esprit européen a anéanti tout ce qui pouvait s'opposer à l'homme: parvenu au terme de ses efforts, comme Rancé devant le corps de sa maîtresse il ne trouve que la mort. Avec son image enfin atteinte il découvre qu'il ne peut plus se passioner pour elle. Et jamais il ne fit d'aussi inquiétante découverte...." 52 .

A civilização ocidental européia pode ser, segundo os personagens de Ling e A.D., explicada nessa época pela destruição de Deus e conseqüente falta de valores, em busca de sua nova imagem, a qual, quando encontrada, mostra sua feiúra e inacessibilidade. O homem ocidental procura sua imagem e para isso mata Deus, mas quando finalmente a alcança, horroriza-se com o que vê e a abandona. Temos então um homem que se aventura para conseguir o que deseja, vence os desafios (até mesmo contra Deus) e quando finalmente poderá desfrutar de sua conquista, a frustração surge: pela imagem tão procurada não há como se apaixonar, ela é reflexo tão somente da Morte.

É a esse diagnóstico pessimista do homem ocidental que chegamos ao final do livro de Malraux; final, aliás, que não difere dos dois primeiros contos analisados. Se a narração é distinta, se o real penetra em La tentation de l'Occident enquanto o

\footnotetext{
${ }_{52}^{51}$ MALRAUX. “La tentation de l'Occident” In Oeuvres Complètes - p. 65.

${ }^{52}$ IBIDEM - p. 110.
} 
fantástico é que impera em Lunes en Papier e Écrit pour une idole à trompe, o diagnóstico que todos esses textos apresentam é, no entanto, semelhante. O homem ocidental (ou os Pecados, ou Pompier) tem um objetivo e para isso enfrenta lutas, age, vence, mas essa vitória, mais que efêmera, é frustrante, vã, insignificante (a diferença é que, se esse era o conteúdo mesmo dos dois primeiros contos, agora ele é apenas relatado, constatado pela observação de um chinês que se encontra na Europa e aceito e concluído pelo francês que se encontra na China). Os Pecados matam a morte, Pompier aprisiona a Clave de Sol, e o homem ocidental mata Deus para encontrar sua imagem - todos vencem, e ninguém consegue desfrutar da vitória. A vitória não pode ter valor nesse mundo sem valores, e é por isso que a frustração sempre está presente nessas obras de Malraux.

Há sim, uma distinção entre as obras no que se refere à forma, mas não em relação ao conteúdo e temas:

A ses débuts, Malraux a pensé que le moyen le plus puissant dont disposait l'artiste pour rivaliser avec le monde et s'exprimer intensément était la création purement imaginaire. Celle qui se servait du réel ne lui paraissait sans doute pas moins capable d'une profonde révelation de l'homme; à tout le moins s'enracinait-elle excessivement, à ses yeux, dans un monde qu'il s'agissait précisément de contester. Or, la plus importante conséquence artistique de l'expérience orientale semble bien avoir été, sur le plan de la création personelle, d'accélérer l'évolution de Malraux vers l'emploi du réel et le choix du roman" 53 ,

o que não o leva a condenar o imaginário puro, tanto que em 1928 ele publica Royaume-Farfelu, obra na qual o fantástico retorna.

Mesmo que haja um emprego maior do real em La tentation de l'Occident, com personagens, cenários e narrativas bem concretos, e uma diminuição considerável do fantástico, as preocupações de Malraux continuam as mesmas: o que seus contos revelam é um homem em busca de uma aventura que lhe possibilite alcançar seu objetivo, o qual, após a conquista, nada mais significa. O que se pode apreender desses três contos analisados até aqui é que a frustração chega não pela impossibilidade de alcançar o que se deseja, mas pela insignificância do desejo

\footnotetext{
${ }^{53}$ VANDEGANS. La jeunesse littéraire d'André Malraux - p. 279.
} 
realizado - o que revela e ao mesmo tempo é conseqüência da total perda de valores que o homem ocidental europeu sofreu e realizou.

Tanto pelo que os personagens fazem (em Lunes en Papier e Écrit pour une idole à trompe) quanto pelo que é relatado em La tentation de l'Occident, é preciso fugir desse mundo sem moral e procurar uma nova noção de homem, e esse é o único meio de combater definitivamente o caos e desespero do homem ocidental. Parece que temos aqui uma ética da busca do ideal e de uma nova noção de homem que permita a reconstrução dos valores e da ordem por meio da aventura e da arte.

A aventura é um dos meios de se tentar alcançar essa nova noção de homem, e mesmo que frustrado, não será abandonado jamais pelos personagens de Malraux e pelo próprio autor - e o mesmo se dá em relação à arte. A arte também é um meio privilegiado para os personagens e para Malraux no combate à perda dos valores: ela deve ter "pour mission d'opposer à la destruction et au chaos universel sa pérennité et son ordre" 54 .

A aventura farfelu e a ficção fantástica são meios de se oporem ao concreto, de negar o caos e colocar alguma ordem e regra (lembremos que o farfelu de Malraux só tem vitória quando associado à harmonia) nesse mundo sem valores. Tanto a arte como a aventura são modos de tentar fugir da Morte, que se mostra muitas vezes na própria vida: "De fait, Malraux utilisera deux arms, l'art et l'action, pour récuser la victoire de la Mort sur l'homme et trouver chez lui un allié de poids: une philosophie de vie fondé sur une éthique de la fraternité" 55.

A arte e a ação parecem ser os únicos momentos - mesmo que efêmeros - nos quais o homem possui sua vida e lhe dá sentido, os únicos instantes em que o homem confronta o mundo contemporâneo da falta de valores: "L'art vif de sa fonction qui est de permettre aux hommes d'échapper à leur condition d'hommes, non par une évasion, mais par une possession. Tout art est un moyen de possession du destin" 56 .

Mas se Malraux diz que a arte não é evasão, e sim possessão, a possessão a que se refere é a possessão do destino, e não do mundo. A arte e a aventura não se voltam para o mundo concreto da falta de sentido mas sim para o destino, para a metafísica, na qual uma nova moral e uma nova noção de homem poderiam ser

\footnotetext{
${ }^{54}$ VANDEGANS. La jeunesse littéraire d'André Malraux - p. 291-292.

${ }^{55}$ SAINT-CHERON, M. André Malraux ou la conquête du destin - p. 20.

${ }^{56}$ frase de Malraux dita em Londres em 1936 segundo MOATTI, C. "Un autodidacte sur les chemins de la création artistique" In CHAMI, André Malraux - Quête d'un idéal humain et de valeurs transcendantes - p. 198.
} 
encontradas. Tanto por meio da luta fantástica da escrita quanto por meio da luta real das aventuras o que os personagens de Malraux procuram é se contrapor ao real, é buscar e vivenciar alhures (no mundo do fantástico, na metafísica) o que não é mais possível encontrar no real (uma moral). O modo como Malraux mostra a relação dos personagens com a arte e também como ele próprio pensa a arte nos revela um pensamento sobre a ética, uma ética da busca do Ideal, da luta contra o real caótico da falta de sentido e valores . 


\section{B) Os Contos de Juventude de Sartre}

Visto de uma maneira um pouco mais detalhada como se dá a literatura para o jovem Malraux - e como podemos, ao compará-la com suas falas e noções sobre a arte, deduzir uma concepção de estética, a qual nos revela uma ética metafísica da busca de uma nova noção de homem - veremos agora como Sartre escreve seus contos nessa mesma época. Embora o critério escolhido seja o mesmo para ambos os autores (uma análise dos textos literários anteriores ao primeiro livro considerado pela crítica - Les conquérants no caso de Malraux e La Nausée no caso de Sartre), teremos um número maior de contos de Sartre para analisarmos, e o motivo é que, se a data inicial da escrita é semelhante $(1920,22)$, a data final desse período é bem distinta (Malraux publica Les Conquérants em 1927, enquanto Sartre só publica La Nausée em 1938)

Pensamos já termos mostrado como, nos contos de Malraux analisados até aqui (Lunes en Papier, Écrit pour une idole à trompe e La tentation de l'Occident), o irreal aparece como oposto ao real, em confronto com este, possibilitando assim uma fuga do concreto, do caos de um mundo no qual os valores não mais existem. A obra de arte, para Malraux, deve ser um fantástico harmônico que rivaliza com o real, que busca encontrar uma nova noção de homem e que portanto, implica em uma questão ética, mas em uma ética que se mostra ideal - a da busca metafísica da noção de homem e a conseqüente busca de uma nova moral que possa "orientar" o homem ocidental europeu. Mesmo que as obras de Malraux pareçam não serem otimistas em relação à uma possível vitória da arte nessa sua função (e mesmo a vitória tem um gosto amargo de derrota ou insignificância), é ela que é o meio fundamental para se exercer essa luta. No combate ético pela busca de valores, a arte é um instrumento essencial.

E se já vimos essa relação entre a estética e a ética através dos contos iniciais de Malraux, tentaremos mostrar agora como ela se dá nos contos iniciais de Sartre: para este a obra de arte quase não se difere do real, está imersa nele e a tal ponto que quase não se os distingue. A ficção lhe parece mais como um meio de exercer a crítica ao mundo burguês e a seus valores, como a necessidade de ação e aventura, do que um modo de se contrapor ao real por meio da fuga. Veremos, por exemplo, que o fantástico está excluído do mundo fictício de Sartre - e mesmo quando ele aparece, no 
caso de Er, l'arménien, é contemporaneizado e bem distinto do farfelu de Malraux -, o qual se mostra bem próximo do cotidiano do próprio autor, indicando assim que ao menos sua técnica romanesca, sua concepção de como deve ser a estética, é contrária à de Malraux. E essa oposição não se encontra apenas no âmbito da forma; o conteúdo também difere: embora os temas muitas vezes se repitam - a questão da aventura, da frustração e do fracasso final -, eles são relatados de modo oposto - se para Malraux essa busca é própria do homem e ele mesmo deseja realizá-la, para Sartre há uma distância que parece não haver em Malraux: a ironia e a crítica permitem um afastamento do conteúdo de seus textos (mesmo sendo o personagem principal quase sempre o alter-ego do autor), de maneira que a aventura pareça ser uma necessidade burguesa que merece ser corroída e zombada, mesmo que Sartre também a pratique. A seriedade com que Malraux encara essa questão da perda dos valores e da busca de uma nova noção de homem é vista por Sartre como uma característica burguesa que deve ser satirizada por meio da ironia e de um veneno endereçados não somente aos outros mas também (e principalmente) a si mesmo.

Tentemos ver então de que maneira essas divergências relatadas aqui de modo bem geral se apresentam nos contos iniciais de Sartre (L'ange du morbide, Jésus la chouette, La semence et le scaphandre, Une défaite e Er, l'arménien) e como elas apontam para uma concepção de estética e uma relação com a ética opostas às de Malraux.

\section{Jésus la Chouette - professeur de province}

Sartre publica esse texto na revista Revue sans titre (sobre a qual, aliás, ele falará em um outro conto que será analisado aqui, La semence et le scaphandre) em 1923. Revista em que jovens universitários se reuniam e decidiam quais textos seus seriam publicados - eis as características do meio no qual Sartre vivia, o qual se mostra bem distinto do meio do jovem Malraux, cercado de amigos editores, escritores e pintores. Embora ambos convivessem com intelectuais e artistas, o meio de Sartre era mais "amador", "universitário", enquanto o mundo de Malraux já era o sério e importante mundo de Gallimard, Ferdinand Léger, Picasso e Max Jacob.

Nesse ano em que Sartre publica seu primeiro conto, Malraux já publicara Lunes en Papier e alguns fragmentos de Écrit pour une idole à trompe e já era, 
portanto, conhecido no mundo artístico não apenas pelos livros e edições raras que ajudava a encontrar e a publicar mas também pelos contos publicados.

Sartre vivia em um mundo oposto, no mundo acadêmico, em Paris, logo após seus estudos em La Rochelle. E é justamente sua vivência em La Rochelle, quando foi levado pela mãe e padrasto para estudar e morar, que o conto narra. E mesmo a distância temporal é pouca, o que não lhe impossibilita, entretanto, um distanciamento irônico.

Mesmo que haja uma aproximação em relação ao tempo e ao real, não podemos dizer o mesmo a respeito do narrador-personagem: ao vivenciar a história, o personagem Paul se distancia dela. Ele é o elemento estranho que chega à La Rochelle e observa o professor e sua família, julgando-os sem a menor comiseração. A distância e o estranhamento possibilitam a crítica, mas se nos textos de Malraux essa crítica visa encontrar uma nova noção de homem, nos textos de Sartre não ocorre o mesmo: a ácida crítica realizada pelo jovem Paul (e por Sartre, por meio de Paul), não tem em vista um fim ideal de buscar novos valores e moral mas o de simplesmente desmascarar os anseios burgueses.

O conto de Sartre é narrado em primeiro pessoa no passado (imperfeito) pelo jovem estudante Paul, que vai à La Rochelle estudar e para isso passa a morar na casa de um professor (Laustreck, Loosdreck - Sartre varia o nome desse professor da província no decorrer do conto, mas o seu apelido é sempre o mesmo - Jésus la Chouette).

Desde o início, o jovem estudante descreve a família com a qual passa a morar de forma bastante cruel: o professor "moral", "Corneille", "exemplar", a mulher que reclama de tudo e despreza o marido, a filha exibida que deseja "caçar maridos", o filho revoltado que traz a "vergonha" à família... Não há nenhum pudor em retratar a família que lhe dava um lar, um quarto e comida. Paul é absolutamente intransigente com a família Laustreck (ou Loosdreck) e, na medida em que participa desse meio, em que vai a um baile com a família e a bares com o filho, revela-se intransigente consigo próprio. A distância que Paul mostra ter no início é relativizada aqui: se sua ironia lhe permite distinguir-se dessa família burguesa que tanto necessita do reconhecimento da sociedade e segue cegamente as normas aceitas, seus atos e comportamento o fazem aproximar-se dela, de tal forma que sua crítica feroz acaba por atacar não só a família mas também a si mesmo. 
Ao mesmo tempo em que Paul se distancia pela ironia, ele se aproxima por compartilhar suas ações. O julgamento, a crítica são permitidos, mas isso não livra o juiz e o crítico de suas próprias ações. Não é possível se posicionar fora desse mundo, como um Deus onipotente e onisciente: mesmo que a crítica seja possível, que ela coloque o indivíduo que a realiza momentaneamente fora do que é criticado, ela não exime seu autor de si mesma - ao mesmo tempo em que a crítica permite um afastamento cínico do que ocorre, ela lança seu autor no mundo, fazendo-o também vítima de suas próprias críticas. Há um movimento incessante entre o estar no mundo e poder, de fora, julgá-lo; e não nos parece possível, ao menos por essa obra de Sartre, um situar-se absolutamente fora do mundo, um julgamento de um superior absoluto e abstrato.

É assim que Paul julga seu anfitrião e professor: "Entièrement détaché des réalités tangibles, nourri de philosophies idéalistes mal digérés, il parlait et agissait dans l'existence comme un grand enfant. En matière morale ou politique ses opinions étaient des utopies délirantes. Il était plus facile encore que les ouvriers, à tromper par les classiques paroles creuses de réunion publique et votait aveuglement pour l'extrême gauche, ce qui ne l'empêchait pas d'être catholique et chrétien fervent"57. Pessoa afastada do real, alimentada por filosofias idealistas e ainda mal digeridas, um professor que ao mesmo tempo votava na extrema esquerda e era católico... Para o jovem e sarcástico Paul, o professor Loosdreck era totalmente alienado.

Paul ridiculariza o professor Loosdreck, e talvez essa sua ousadia se deva ao medo que o professor mostra ter de seus alunos e da opinião pública. Aceito com reticências pela sociedade de La Rochelle, todo ano ele é alvo de "chahut" (brincadeiras escolares nas quais os alunos, por meio de barulho e algazarra, zombam do professor - uma espécie de trote que os alunos fazem ao professor). A cada novo ano, os alunos preparam uma aula para desmoralizar Loosdreck com algazarras dentro da sala de aula; e no ano em que Paul vai para La Rochelle, ele também participa dessa afronta ao professor - e não só ele, o próprio filho do professor também participa e tem papel essencial na organização e exposição do dia do "chahut".

Parece-nos que o mundo real não perdoa professores idealistas, preocupados com a aceitação e tendo medo de ser ridicularizado (a tal ponto que é ridicularizado por isso). Loosdreck tem medo da sociedade e isso o faz escravo dela. É o que vemos

\footnotetext{
${ }^{57}$ SARTRE. "Jésus la Chouette" In Écrits de Jeunesse - p. 74.
} 
no episódio contado do bar: Paul e Adolphe (o filho do professor) vão a um bar na beira do cais com algumas prostitutas e lá entram o professor com alguns políticos para traçarem as estratégias de campanha para a prefeitura. Os meninos tentam se esconder do professor, mas este os vê e arma um escândalo no bar, o que faz os políticos desprezarem-no e não mais quererem seu apoio. E se não bastasse a vergonha do professor perante o que seu filho fizera e o desprezo dos políticos que tanto admirava, o acontecido é tornado público por um outro professor da mesma escola, que escreve no jornal contra Jésus la Chouette, ridicularizando-o pelo escândalo no bar.

É então que a cidade, que só esperava um motivo para desvelar sua crueldade, surge com força. Foi só o fato se tornar público para que as humilhações pudessem ser feitas diretamente, pudessem ser justificadas. As críticas ao professor e sua família, que até então eram veladas e sutis, se tornam socos, gritos e risos em plena rua, o que até mesmo os adolescentes fazem. E se antes Adolphe participava com os outros adolescentes dessas algazarras públicas, agora ele é o alvo: os colegas de classe, incluindo o personagem-narrador Paul, batem em Adolphe e gritam com a mulher e a filha do professor, assustando-os e determinando a perda do pretendente de Marguerite (a filha), o qual não cortejaria uma moça tão ridicularizada pela sociedade.

É certo que Paul sente um pouco de pena dessas mulheres, mas isso não o impede de participar dos gritos e xingos... Paul se mostra o tempo todo ambíguo: fora dessa sociedade devido às ácidas críticas e ironia que faz a ela (e isso lhe é permitido porque não é de La Rochelle) e ao mesmo tempo dentro dela, já que pertence a esse mundo burguês que critica e do qual tanto participa; fora da família por ser um estranho que conviverá com ela por apenas um ou alguns anos, mas dentro dela por morar em sua casa e participar de seus programas familiares; fora do grupo de amigos tão "cruéis" que se voltam contra a família por estar, de certo modo, ligado a ela, e dentro do grupo por participar de suas brincadeiras grotescas.

Paul parece-nos ser um personagem "entre”, entre a abstração da ironia e a concretude das ações, o afastamento absoluto da família e dos amigos (enfim, do mundo burguês) e o pertencimento concreto a ele. Parece haver indícios aqui de que uma fuga e afastamento totais desse mundo não são possíveis: a crítica permite um afastar-se, mas um afastar que inclui o pertencimento - e assim também parece ser a arte para Sartre: mesmo que permita uma negação do real, ela parte dele e se volta a 
ele, movimento este que não conseguimos detectar - até agora - nas obras de Malraux (a este parece importar mais o movimento de ida que o da volta).

Não é possível se situar fora desse mundo, ser apenas um espectador (crítico ou passivo) do que ocorre, e Paul, mesmo conseguindo não permanecer totalmente imerso no que vive, mesmo tendo a crítica e a ironia como meios de se distanciar dos acontecimentos, precisa agir e nisso mostra sua imersão no real (sua passividade e inação não o livram do pertencimento ao cotidiano). Podemos ver essa relação até mesmo entre o Paul narrador e o Paul personagem: embora o narrador não seja mais o personagem (já que alguns anos se passaram, e é essa distância que possibilita que ele seja tão cruel consigo mesmo, sem justificar e desculpar seus atos), ele o é, de certa maneira (já que foi ele quem vivenciou tudo aquilo que é narrado).

É com indiferença - distância cínica que é mantida o tempo todo - que Paul narra os acontecimentos finais do conto: as mulheres, junto com Paul, tomam o bonde logo após serem xingadas nas ruas e vêem que o professor Loosdreck também o pega. Diante dele, sua mulher começa a fazer um novo escândalo e o professor, tão pressionado por todos os lados, nada diz, joga-se do bonde e morre. O conto termina no enterro do professor, e Paul já se encontrava distante do acontecido (a família o levara embora, ele já não mais moraria com a família do professor): "Et voilà que maintenant on l'emportait, pauvre cadavre rompu, au milieu de l'indifférence et des rires. Sa mort comme sa vie avaient sombré dans le ridicule" ${ }^{\Perp 58}$.

A morte do professor Loosdreck só vem confirmar, para o jovem Paul, sua vida vivida no ridículo. A covardia, a ambição, o medo da opinião alheia: tudo isso fez de Jésus la Chouette mais um motivo para comédia que para drama, e sua própria filha lamenta na morte mais o fato de ter de ficar de luto (e não poder se casar) do que a perda do pai. Esse mundo burguês fútil zomba de si mesmo (a filha despreza o pai, a sociedade ridiculariza a família), tal como Paul de 22 anos fala do Paul de 17 anos, tal como Sartre fala de si mesmo.

A ironia está presente em todo o conto, e ela se mostra totalmente concreta, ligada ao que foi vivido. Há um realismo um tanto grotesco nessa obra de Sartre, já que este pretende narrar o que "realmente" aconteceu. E embora haja a preocupação com o estilo (Rybalka e Contat alertam para os temas em comum com Madame

\footnotetext{
${ }^{58}$ IBIDEM - p. 134.
} 
Bovary de Flaubert), a impressão que nos fica é que o conteúdo é que porta a força maior do texto e não a forma.

O primeiro conto de Sartre, Jésus la Chouette se mostra, portanto, bem distante daquele fantástico que vimos em Malraux, e a aventura aqui narrada é no máximo uma brincadeira de adolescente (que não deixa de ser perigosa), ou uma aventura com ações sutis, com um desprezo surdo mas imponente, uma ironia que despreza, um desprezo que ridiculariza, uma acidez que dissolve aos poucos sua vítima, que, no entanto, escolhe esse papel. E é justamente essa aproximação com o "Mal” que deve ser, para o jovem Sartre de 17 anos, a função do escritor. Segundo Contat e Rybalka em Écrits de jeunesse,

Avec Nizan, vers 1922, Sartre développe une théorie qui marque un changement dans sa conception de la littérature: l'écrivain n'est plus l'homme du Bien, il côtoie le Mal, et son office est d'en rendre compte après y avoir jeté des coups de sonde au risque de s'y perdre; le romancier doit montrer l'homme en proie au Mal, il est lui-même 'l'homme du Mal', qui n'oublie pas le Bien mais le reintègre par le mouvement même qui lui fait témoigner du Mal où il s'immerge, tel un scaphandrier en plongée ${ }^{59}$.

Sartre, no momento em que escreve Jésus la Chouette, pensa que o escritor deve ser o homem do Mal, aquele que o rodeia com o risco de nele se perder e assim, mostrar o homem atormentado pelo Mal, tal como toda a cidade de La Rochelle parece fazer com o professor, tal como o professor faz consigo mesmo ao ser incoerente e covarde, tal como o narrador Paul faz com os personagens, incluindo a si mesmo. É preciso mostrar o homem tal como ele se mostra na "realidade" - imerso na lama do Mal - esta é a função do escritor. A ironia que Sartre destila a seus personagens - mostrando-se portanto distante deles - não nos impede de vê-lo também mergulhar nesse lamaçal: o escritor não deve fugir desse Mal que o rodeia, deve enfrentá-lo mesmo tendo o risco de nele se perder, e não fugir por meio de um fantástico que possa fornecer outros meios para se alcançar uma nova noção de homem, como Malraux desejava.

Para Sartre, nesse primeiro conto, a arte parece apontar para uma direção oposta: se se apresenta como crítica ao real, como ironia, ela não foge, no entanto, do concreto. Parece não haver aqui a necessidade de se lutar contra o real e muito menos

\footnotetext{
${ }^{59}$ SARTRE. Écrits de Jeunesse - p. 52.
} 
a de encontrar alguma nova moral: o que Sartre faz é uma crítica aos valores, mas essa crítica é feita por ela mesma e não na expectativa de encontrar algum valor válido, o que também seria ironizado por ele.

Mas se o primeiro conto de Sartre narra um acontecimento próximo ao vivido por ele e se mostra pouquíssimo distante do real, quase uma não-ficção, o segundo conto, L’ange $d u$ morbide, é mais fíctício. Vejamos se há alguma mudança significativa entre esses dois contos.

\section{L'ange du morbide}

Esse segundo conto escrito por Sartre foi publicado na mesma revista Revue Sans Titre, e antes de Jésus la Chouette. Ambos os textos foram escritos em 1922, quando Sartre estudava em Paris junto com Nizan e um grupo que se pretendia artista, intelectual. E se Jésus la Chouette, escrito primeiro, foi publicado em fascículos nessa revista em 1923, esse conto, L'ange du morbide, o foi em 1922 mesmo.

Não há, portanto, nenhuma diferença entre o que nosso autor vivenciava na época em que escreveu os dois contos, e por isso não é possível procurar alguma mudança significativa entre as obras e nem mesmo no que o jovem Sartre pensa sobre a arte. Continuamos com a mesma idéia, compartilhada por Nizan, de que o escritor deve sempre ser e mostrar o homem ameaçado pelo Mal.

E é justamente um outro professor burguês que será vítima da sátira sartriana. O anjo do mórbido, estranho título esse, o de um anjo ligado ao mórbido e não a Deus, próximo do Mal, do diabólico. Este é o anjo ideal que o professor Louis Gaillard procura e encontra em uma pequena cidade durante as férias.

Novamente o professor é retratado de forma cruel mas sempre com um certo humor: nele vemos as mesmas aspirações de Jésus la Chouette, o desejo de se confundir com o idealismo romântico, sendo, dessa vez, admirado por um grupo de amigos, que o consideram um gênio, justamente porque procura reproduzir o gosto do mórbido retratado nos personagens românticos. Louis Gaillard, segundo o narrador, "avait tourné tout l'élan de sa jeunesse vers le morbide, par snobisme, et aussi parce que son esprit n'était plus qu'une pauvre chose faussée, un rouage de montre détérioré, qui tourne à l'envers" ${ }^{60}$.

\footnotetext{
${ }^{60}$ SARTRE. "L'ange du morbide" In Écrits de jeunesse - p. 45.
} 
São as férias desse professor que o conto narra, agora com um narrador mais distante. No conto Jésus la chouette tínhamos uma proximidade com o que era narrado devido à presença do narrador como personagem (embora a ironia exercida por ele nos deixasse com a impressão de uma proximidade distante, ou de uma distância próxima), mas aqui, em $L$ 'ange du morbide, não há essa proximidade.

Louis Gaillard é considerado pelo narrador como um homem medíocre que é considerado gênio, super-homem, pelos amigos. E em busca de mais uma história romântica nosso professor viaja para uma pequena cidade entre as montanhas, dividida entre católicos e protestantes e cheia de pequenos hotéis que acabam por se tornar sanatórios. É em busca de paz e ao mesmo tempo do mórbido que Gaillard viaja.

Ao chegar nessa pequena cidade, o professor se hospeda em um hotel quase abandonado, no qual havia um padre cego e três velhas, o que dava prazer à morbidez do professor, a qual, no entanto, não era completa, já que as velhas deveriam estar mais sujas e mal-vestidas para isso.

E ao saber que havia muitos sanatórios nessa cidade, logo o professor imaginase vivendo uma aventura, apaixonando-se por uma tuberculosa, o que seria o auge de seu gosto pela morbidez e seu idealismo. E esse desejo é realizado: em um passeio, conhece Jeanne Hongre, uma jovem tuberculosa que não estava internada mas vinha passar uma temporada nos ares da cidade, e por ela ele se apaixona. Na verdade, em seus encontros o professor lhe fala mais de teorias que de sentimentos ou dele mesmo, e sua tagarelice era tanta que mal deixava tempo para que Jeanne se apresentasse ou respondesse. Jeanne não o amava, mas gostava de se encontrar com alguém que tanto falava (o que a fazia se esquecer um pouco de si mesma e de sua doença), e tinha o cuidado de não tossir na frente dele para não espantá-lo e decepcioná-lo.

Um dia, no entanto, ele decide falar de sua teoria sobre o amor, e enquanto falava, ela sufoca e começa a tossir. No início ela tenta se controlar, mas aos poucos deixa a tosse tomar conta de seu corpo e mente. E diante desse espetáculo mórbido e real de sangue e tosse, o professor se horroriza:

Ses falotes et tout idéales représentations de la phtisie ne l'avaient point préparé à ce spetacle; sa médiocrité n'était pas faite pour le supporter, sa morbidesse factice lui était un bien faible cuirasse contre l'horreur qu'il avait de cette amante cauchemardesque. Il oubliait la douceur réelle de cette 
femme, son vrai caractère, il lui semblait qu'un autre être, effroyant et mystérieux s'était glissé en elle, quelque chose comme l'ange du morbide, de ce morbide qu'il avait tant recherché ${ }^{61}$.

Se o professor buscava com ardor a morbidez, era, na verdade, apenas a idéia que lhe agradava, era apenas a morbidez medíocre e fingida que mostrava ter: quando o "anjo do mórbido" deixa de ser apenas forma para "possuir" o corpo de uma jovem, quando se materializa, torna-se concreto e palpável, ele deixa de agradar, passa a horrorizar aquele que anteriormente o buscava.

Temos aqui aquela mesma imagem relatada por Malraux em La tentation de l'Occident, quando se chega ao diagnóstico de que o homem ocidental procurava sua imagem, mata Deus para isso, e quando a encontrou, percebeu que não dava para com ela conviver. O mesmo ocorre com o professor: ele deseja o mórbido, mas não o suporta quando o encontra. No entanto, há uma grande diferença no modo como Sartre e Malraux vêem essa questão: se para este é necessário permanecer no ideal, buscar uma nova noção de homem de outra maneira que não pelo caos dos valores; para aquele essa necessidade não se põe. O que ele parece mostrar é o ridículo daquele que deseja o ideal e não suporta o concreto, daquele que vive em busca de uma moral estabelecida. No entanto, se se deve zombar desse ideal puro, dessa busca pela total abstração, é a mesma reação que se deve ter com o real grosseiro, com o concreto das normas estabelecidas e nunca questionadas, com o mundo burguês das aparências reais semelhantes às aparências ideais.

É o que Sartre nos mostra no final do conto. Após enfim encontrar "o anjo do mórbido" que pensava tanto amar, Louis Gaillard se amedronta e decide esquecer todo esse desejo ideal pela morbidez. Horrorizado com a "verdade" e "realidade" do “espetáculo" (o qual, para ele, só podia ser fictício no sentido de fantasia, ideal), o professor foge da moça, volta ao hotel - o qual lhe parece, dessa vez, mórbido demais - e sai da cidade. Volta ao lugar em que vivia, rompe com todo seu jeito antigo de viver, inclusive com os velhos amigos e começa uma "nova" vida, tipicamente burguesa e portanto, nada perigosa. Ele se casa com uma moça sadia e aos 55 anos recebe a Legião da Honra, "brevet incontesté de 'Bourgeoisie"” 62.

Se a busca ideal pela morbidez era ridicularizada, essa busca ideal pelo reconhecimento e bem-viver burguês também o é. O narrador não poupa o professor

${ }^{61}$ IBIDEM - p. 48.

${ }^{62}$ IBIDEM - p. 49. 
em nenhum momento: seja na busca da morbidez, pelo esnobismo, seja na busca de uma vida "normal", ele é um homem medíocre. Mesmo que a narração nos pareça distante (ao menos não tão próxima quanto a de Paul narrador e personagem de Jésus la chouette), o narrador não descreve imparcialmente o que narra: diz claramente que Gaillard é medíocre e a ironia e brevidade com que termina o relato nos deixa ver que a mediocridade e a covardia perante o mundo é a mesma no modo de vida nobre e ideal, e no burguês e limitado. A mudança operada pelo professor não foi uma mudança real, não mostrou nenhuma ruptura com a busca por definições e "enquadramento" em um conceito - o que modificou foi o conteúdo da busca: se antes o desejo era pela morbidez, agora é pelo conforto - mas não sua forma, pois o professor continua a desejar um modo totalmente definido e limitado de viver, que não dê lugar para o inesperado das coisas e para sua liberdade. Louis Gaillard deseja se definir definitivamente nos dois modos, e é essa busca que deve ser satirizada, criticada.

E se a crítica que Sartre realiza é justamente ao desejo de definição confortadora e limitadora do que é o homem, ele não poderia colocar essa busca como necessária, como Malraux parece fazer em seus contos iniciais. Mesmo que o homem venha a ser definido posteriormente (em O ser e o nada) como um Para-si que deseja ser Em-si-Para-si, essa definição não deve ser teticamente seguida, o que denotaria má-fé.

Nesse segundo conto de Sartre, L'ange du morbide, temos, portanto, a mesma crítica ácida à burguesia e seus desejos de aventura, idealismo e reconhecimento que vimos em Jésus la Chouette. O desejo de Sartre nesses dois contos é o de provocar quem o lê e não o de procurar ou propor uma resposta ao que descreve e critica.

E basicamente o mesmo ocorre em seu terceiro conto, La semence et le scaphandre, o qual veremos agora.

\section{La semence et le scaphandre}

Esse conto de Sartre foi escrito dois anos após os dois primeiros, em 1924, mas continuou inacabado, sendo publicado (em partes) apenas em 1971, na revista "Magazine littéraire".

Diferente do segundo conto e mais semelhante ao primeiro no que se refere ao uso "ingênuo" da realidade vivida, La semence et le scaphandre retrata novamente um acontecimento recente na vida do jovem Sartre, agora tendo como alter-ego o 
personagem Tailleur. Narrado em primeira pessoa, o conto nos relata a história de dois amigos e de suas relações com a literatura.

Trata-se da amizade entre o personagem-narrador Tailleur e o jovem Lucelles, identificados quase que imediatamente como sendo Sartre e Nizan, o amigo com quem Sartre sempre teve uma relação forte e inconstante. Durante uma briga, um rompimento breve entre ambos (de março a outubro de 1923, segundo Contat e Rybalka em Écrits de jeunesse), o estudante Sartre escreve um conto no qual descreve essa amizade e também a fundação de uma revista por um grupo de jovens - a revista Semence do título ou precisamente a Revue sans Titre na qual Sartre publicara seus dois contos anteriores.

Temos então a história de uma amizade, a qual não pode ser relatada sem considerar suas relações com a literatura. Para os jovens Tailleur e Lucelles, a literatura era essencial e eram constantes as conversas entre os dois sobre a concepção de arte. Essa amizade entre os dois jovens estudantes do liceu estava baseada nesse gosto por arte (principalmente literatura), filosofia e discussões; e não poderia ser bem narrada sem tratar essas questões.

É assim que o jovem Tailleur define sua amizade com Lucelles: "La divergence profonde de nos esprits, entièrement supprimée dans nos rapports quotidiens, où nous n'existions plus qu'en fonction l'un de l'autre, se manifestait surtout dans nos écrits littéraires" ${ }^{\prime 63}$. Embora no cotidiano ambos vivessem juntos o tempo todo, se vissem praticamente como inseparáveis (já que sempre falavam "nós" no lugar de "eu" ou "você"), havia algumas divergências importantes entre eles, como a humilhação que às vezes o "nós", quando era sabido que se tratava de um "eu", causava; e também, e principalmente, em relação aos escritos literários de cada um.

A divergência mais profunda em relação à amizade se dava no campo dos escritos literários. Tailleur comenta que ambos escreviam desde a mais tenra infância e que no início ambos se pretendiam românticos, mas que ele era "plutôt porté vers le réalisme" ${ }^{, 64}$, enquanto Lucelles, "plus discret et plus constructeur, préférait être impersonnel"65. A amizade e as convergências entre os dois não escondiam as diferenças nos gostos literários e nas escritas de suas ficções. Se Tailleur gostava de Mirbeau, Lucelles tinha o espírito delicado e um temperamento poético, o que o fazia,

\footnotetext{
${ }^{63}$ SARTRE. "La semence et le scaphandre" In Écrits de jeunesse - p. 145.

${ }^{64}$ IBIDEM - p. 145.

${ }^{65}$ IBIDEM - p. 145.
} 
ao menos literariamente, escrever belos idílios de uma psicologia complicada e "limpa".

E se para mostrar belos idílios psicológicos era melhor ser impessoal, Tailleur pensava que, ao contrário, para mostrar a sujeira e o Mal era mais propício (ao menos considerado com mais sucesso) ser totalmente pessoal, autobiográfico. Tailleur reconhece que fizera sucesso ao falar de um acontecimento pessoal e por isso decidira sempre relatar acontecimentos autobiográficos: "Enfin je fis un petit roman d'aventure qui m'était arrivé quelque temps auparavant; j'eus quelque succès dans un cercle restreint et je fus décidé par ce mince triomphe à ne plus faire d'autres récits que ceux d'événements de ma propre vie" ${ }^{\natural 6}$. Trata-se, evidentemente, do conto Jésus la Chouette, admitido pelo autor como verídico e publicado há pouco tempo.

O escritor não é aquele que se encontra "limpo" diante da imundície do mundo, ele é o que mergulha reflexivamente nela a fim de melhor refletir e ser o nada de ser que é - e por isso não poderia se ausentar de seus escritos; deve, mesmo que não direta e explicitamente, inserir-se nessa crítica mordaz que faz à sociedade. $\mathrm{E}$ pensamos que esse é o motivo principal da permanência do "personagem-autor" nas obras romanescas de Sartre.

Como diz Contat e Rybalka em Écrits de Jeunesse, "l'impulsion de la création romanesque chez Sartre: une crise personelle qu'il s'agit de résorber dans et par l'écriture, en la transposant dans un récit dont le protagoniste est un alter ego jugé sans complaisance" ${ }^{\prime 67}$. Sartre parte, portanto, de suas crises, do que lhe acontecia, para então narrá-los de forma não isenta, mas sim totalmente inserido, não só nos acontecimentos mas também em suas críticas e sátiras. O jovem escritor Sartre julga seus personagens e a si mesmo com excessiva severidade e ironia, e é desse modo também que narra seu envolvimento - e o de Nizan - na fundação da revista Revue sans titre.

É justamente com o relato do início da Revue sans titre que Sartre prossegue La Semence et le scaphandre. O conto continua falando das reuniões entre os dois amigos, no convite feito a Lucelles e expandido a Tailleur (por meio do "nós" de Lucelles) para participarem com textos e idéias para a criação da revista "La semence”. Sartre relata as confusões e discussões desses jovens, as tentativas cômicas

\footnotetext{
${ }^{66}$ IBIDEM - p. 145.

${ }^{67}$ IDEM. Écrits de Jeunesse - p. 138.
} 
e ridículas para arrecadar fundos para a publicação, as reuniões para se decidir o nome da revista e os textos que seriam publicados.

E é em uma dessas reuniões que se decide que Tailleur publicaria um conto em fascículos, garantindo assim a continuação de sua publicação nos próximos números, para os quais há muitas discussões sobre quais textos serão publicados. Tailleur leva vantagem por publicar um pequeno romance em partes, o que provoca irritação no amigo Lucelles, que precisava garantir a publicação de seu texto. Essa questão levará, segundo Tailleur, ao início do fim da amizade:

Lucelles même me dit en riant un jour: 'Au fond tu es le plus malin; tu as le roman, le gros morceau. Tu nous as passé sur le ventre'. Et je le connaissais trop pour ne point percer à jour son dépit. Je lui répondis, désespéré, que s’il voulait, je lui cédais ma place. Mais il poursuivit froidement: 'Que veux-tu que ça me fasse? Tu écris un roman, tu le publies, tant mieux pour toi. Te le publies pas: tant pis. Ça ne me regarde pas. Je constate seulement que tu as choisi le gros morceau: voilà'. Et il me tourna le dos. Par la suite nous restâmes amis comme au passé, mais je sentis qu'entre lui et moi un imperceptible facteur de division s'était glissé ${ }^{68}$.

As discussões para o segundo número da revista "La semence" levaram a um distanciamento, não real, mas importante ns relações de Tailleur e Lucelles e a amizade toda será composta, para eles, dessa admiração mútua junto com uma enorme rivalidade.

O conto acaba com esses relatos da revista La Semence e o encontro com os organizadores de uma outra revista, "Le scaphandre" sem no entanto, terminar. O conto resta inacabado e apenas sua primeira parte foi publicado 50 anos depois (e segundo Contat e Rybalka, o conto foi interrompido porque a amizade com Nizan foi retomada depois dos seis meses de rompimento).

Sartre relata, nesse conto, as ambigüidades de sua amizade com Nizan e também o meio de publicação para os jovens estudantes do liceu. Sua sátira, sua ironia se endereça também aos jovens que tudo fazem, inclusive colocar uma grande amizade em risco, para ter seus textos publicados. É a ambição desses jovens intelectuais que é mostrada e ironizada. "Ce qui exerce surtout la verve de l'écrivainau-futur est précisément la satire de son ambition et de celle de ses jeunes gens. Sartre

${ }^{68}$ IDEM. "La semence et le scaphandre" In Écrits de Jeunesse - p. 180. 
prend sur ce désir un recul narquois et le pousse ao grotesque (...) Un des thèmes essentiels de Sartre, celui-là même de La Nausée, apparaît ainsi en filigrame de ce récit satirique: l'écriture ne vaut rien, mais rien ne vaut l'écriture" ${ }^{\text {"69. }}$.

É a questão da escritura e do que se faz para ter seus textos publicados que é mostrada aqui, tanto no que tem de belo (as discussões e busca pelo melhor meio de publicar os textos) quanto no que tem de maléfico (nas brigas por ego e reconhecimento).

Novamente, sem complacência com os outros e nem consigo mesmo, Sartre narra o que lhe aconteceu com uma distância que implica aproximação. Por meio do personagem-narrador Tailleur (seu alter-ego), satiriza sem leveza seu mundo, seu meio e si mesmo. A provocação, a ironia que não isenta nem mesmo o irônico estão sempre presentes nos textos de Sartre, ao menos nos que vimos até agora. Seja em Jésus la Chouette e La Semence et le scaphandre (nos quais a autobiografia está fortemente presente e é admitida como tal), seja em L'ange du morbide (no qual a ficção aparece com mais força), a ironia e a crítica andam juntas - Sartre narra e ridiculariza os anseios de aventura, ambição e reconhecimento da burguesia, e se inclui nessa crítica.

A literatura parece ter para o jovem Sartre a função de descrever os homens atormentados pelo Mal e em busca inutilmente de algum lugar seguro no qual esse perigo de se afundar no Mal não surgisse. O homem está às voltas com o Mal e deve conhecê-lo, com o risco de nele se perder ou afundar - e toda fuga desse enfrentamento, mesmo que seja comum a todos os homens, deve ser denunciada e criticada. E é isso que o escritor, para Sartre, deve fazer. Mesmo no conto em que o real não aparece de modo totalmente autobiográfico, é dele que Sartre parte e para ele que se volta, de modo a refletir criticamente o que é feito e olhado. A ficção é um espelho deformador que permite ao escritor olhar o mundo e a si mesmo de forma distanciada e distorcida mas não ausente e isenta: esse espelho exige o comprometimento de quem o vê, seja para concordar ou negar, mas o posicionamento é exigido ${ }^{70}$.

Mas vejamos como essa crítica se dá no próximo conto.

\footnotetext{
${ }^{69}$ IDEM. Écrits de Jeunesse - p. 139.

${ }^{70}$ É essa a noção de engajamento que Sartre colocará em Que é a literatura?
} 


\section{Une défaite}

Nesse pequeno romance temos de volta a ficção não relacionada de maneira simples e direta com o real. Não temos aqui um acontecimento vivido por Sartre nem mesmo presenciado por ele. Embora o personagem principal pertença ao meio em que Sartre vivia (a École Normale Supérieure) e tenha um amigo que se pareça em tudo com Nizan, o relato do livro se distancia do que lhe aconteceu, já que Sartre nunca escolhera um mestre para seguir e obedecer (ao contrário, seu desejo era o de contrariar seus mestres).

Texto escrito em torno de 1927, sobre a história de um jovem estudante que se mantém numa relação ambígua com um professor e sua esposa, relação essa que espelha a mantida por Nietzsche com Wagner e Cosima Wagner (segundo Contat e Rybalka, Sartre tinha lido livros sobre a biografia de Nietzsche, o qual lhe interessa mais por ser um "homem só", por se pretender "o grande homem" que por sua filosofia), Une défaite não foi publicado.

Mas pelo que dizem Contat e Rybalka na introdução ao conto em Écrits de Jeunesse, esse foi o primeiro romance em que Sartre apostou. Segundo o que disse em uma entrevista tempos depois, ele pedira a Nizan para que levasse o início do texto à Malraux, na esperança que esse o recomendasse a Gallimard. Temos então o primeiro encontro entre Sartre e Malraux, feito por intermédio de Nizan e do romance Une défaite, o qual, aliás, será recusado por Malraux. Para Sartre, o julgamento negativo de Malraux, transmitido via Nizan, desencorajou-o na continuação da escrita do texto. No entanto, é possível que Malraux nem mesmo tenha tido conhecimento desse texto de Sartre, já que nos arquivos da Gallimard não contém nenhuma informação sobre o assunto e também e principalmente porque é provável que Nizan não tenha transmitido o texto a Malraux, já que só começou a ter relações com ele em 1933.

Une défaite é narrada, assim como L'ange du morbide, na terceira pessoa, com um narrador que se mostra presente e interfere na narrativa, que dialoga com o leitor e julga seus personagens, inclusive aquele mais próximo de si mesmo, que é o estudante Frédéric, designado desde o início como bruto.

Ele é o jovem que soube, por meio de um colega, que o escritor e músico Richard Organte (o Wagner da história) precisava de uma pessoa para dar aulas às filhas de sua mulher, e para conseguir essas aulas, vai à casa de Organte para uma entrevista no dia seguinte, sem sonhar que esse homem se tornaria seu mestre, o que, se existia em seu sonho, não deveria existir em sua realidade. Frédéric 
aimait les hommes à sa manière. Il méprisait chez les autres cette élégance qu'il aurait voulue pour lui: il les voyait malsains, moustachus, avec un petit ventre et des avants-bras velus et gonflés de graisse jaune. Il ne se dissimulait point leur lâcheté, leur paresse, leur égoïsme. Mais il les dotait d'une grande force physique et d'un grand courage au labeur, de ruse, de ténacité. Il aimait les petits conquérants cyniques et laids qui se déployaient sur la terre, sans respect et s'appelant à grands gestes les uns les autres. Il aimait leur endurance, leur laideur et leur puissante souffrance qui sentait la sueur et le vin. Il les voyait larmoyants et peureux, puis soudain tournant le dos à l'ennemi et lui montrant insolemment leur derrière. Et il aimait les livres qui les représentaient tels, petit peuple criard, insolent et magnifique, comme Panurge au demeurant le meilleur fils du monde" ${ }^{71}$.

Para Fréderic, os livros devem mostrar as pessoas como elas são, com sua insolência e sofrimento. E é sobre sua concepção de filosofia e literatura que Frédéric falará a Organte na entrevista. Organte mostra o desejo de falar com um jovem, de saber o que os jovens pensam. E diante da pergunta de Organte pela política, Frédéric diz que não se interessava por isso e Organte parece se interessar por esse jovem "intacto", que não é um jovem comum. Aquele então pergunta o que Frédéric faz e esse, acreditando na sinceridade do escritor e músico, responde que faz filosofia e que seu desejo é o de alcançar um ponto de vista, o que justamente a filosofia the daria: "Vous comprenez... je voudrais... écrire. Seulement je voudrais ramener... tout ce que je dirai à... un point de vue... un seul point de vue. Ce point de vue je voudrais que la philo me le donne" ${ }^{92}$. A filosofia, para Frédéric, é quem lhe daria esse único ponto de vista sobre as coisas, e é isso que ele busca nela - o que não impede Organte de achar isso ingênuo, pensamento de adolescente que ele mesmo fora outrora, e com o qual ele podia ter apenas simpatia, a qual diminui a partir do momento em que o jovem ingênuo e auto-confiante Frédéric não lhe parece mais novidade.

E enquanto Organte fazia um interrogatório "sutil", Frédéric pensava que estava sendo sinceramente questionado com interesse, ou melhor, pensava que ambos faziam confidências ao outro de seus pensamentos, sentimentos e vontades. Ao ser perguntado sobre o que gostaria de escrever, Frédéric responde: "Des romans. Mais pas comme ceux qu'on écrit maintenant. C'est de la couchonnerie. Je voudrais que la

\footnotetext{
${ }^{71}$ SARTRE. "Une défaite" In Écrits de Jeunesse - p. 218.

${ }^{72}$ IBIDEM - p. 226.
} 
réforme du roman fût de le rendre aussi difficile qu'un ouvrage de philosophie et qu'il s'occupât de notre vie intelectuelle au même titre que de notre vie affective, qu'il montrât l'homme au travail et raisonnant"73.

A literatura, para o jovem estudante, deve se ocupar tanto da vida afetiva quanto da intelectual, e deve mostrar o homem em ação. Em nenhum momento Frédéric pensa na literatura como fantasia, como uma narração harmônica mas fantástica do que ocorre. É o homem, ou melhor, o homem real, concreto, com pensamentos e sentimentos, agindo, que deve ser tratado na ficção.

Depois dessas conversas Organte se propõe a contratar Frédéric para ser o preceptor das filhas de sua esposa, à qual ele define o jovem como sendo um pequeno charmoso bruto, jovem este que define Organte a seu "Ancien Ami" como "sendo o que seremos mais tarde”. Enquanto Organte vê em Frédéric um jovem ingênuo e bruto, este vê em Organte seu igual mais velho, um mestre que pode mostrar a ele o caminho a ser seguido para se tornar, ele mesmo, um intelectual e mestre. Com isso, no entanto, Frédéric não se sente inferior, um simples ajudante de Organte: ele pretende, junto com o mestre, escrever livros e elaborar teorias, ou melhor, uma teoria (um ponto de vista).

Frédéric é então contratado para dar aula para as duas filhas de Cosima (o mesmo nome da mulher de Wagner), a mulher de Organte. Logo após sua primeira aula, resolve contar um conto de fadas para a duas, mas quando Cosima entra na sala, nenhuma história lhe vem à cabeça. Ele se encanta com a beleza glacial da esposa de seu mestre e começa, vagarosamente, a inventar um conto de fadas sobre um rei que "via almas" e fazia o mal. Um gênio resolve dar um filho à mulher do rei sem que ele tivesse, no entanto, esse "dom" maléfico, e quando a criança faz 15 anos, seu pai morre. Sem poder ver almas, não é bom nem mal, mas quando se perde em um caminho, começa a conversar com uma jovem e a partir de então Cosima ajuda Frédéric a compor o diálogo entre eles, como se fosse a moça encontrada pelo jovem rei. Nesse diálogo, o jovem brinca de ver na moça uma alma, assim como a que ele tinha (embora não pudesse reconhecer a alma dos outros, sabia-se detentor de uma), e só aí percebe que ela guardava em si um universo secreto que lhe seria sempre estranho e passa a ter medo e ciúmes desse mundo e só então percebe que tudo, até mesmo seu cavalo, tinha alma, era inacessível a ele. Depois de um tempo, ele volta a

\footnotetext{
${ }^{73}$ IBIDEM - p. 229.
} 
procurar a jovem, que lhe revela então que pensava no príncipe, que esse mundo desconhecido era na verdade, dele e ele.

De um modo bem sintético e esboçado, alguns temas da filosofia de Sartre começam a aparecer: as questões da consciência, do olhar e do outro são centrais nesse conto de fadas inventado e também nos olhares mútuos de compreensão entre Frédéric e Cosima, entre o jovem rei que conhece o desconhecido e a jovem que lhe mostra que o desconhecido é o conhecido.

Dias depois, ao jantar na casa dos Organtes, e após um convívio direto, Frédéric já considerava Organte seu mestre e até propôs escreverem um livro juntos, que falasse das conversas que tinham, o que é prontamente rejeitado por Organte, o qual, no entanto, começa a escrever uma obra sobre Michelângelo. Mas algumas decepções começam a aparecer... durante um jantar em que Cosima não estava, Frédéric percebe que Organte se importava demais com a etiqueta, o que não impediu, no entanto, que Frédéric olhasse Organte cada vez mais como mestre e menos como amigo.

Mas se mesmo como mestre Organte continua sendo seu igual, alguém que Frédéric será quando mais velho, Cosima permanece impenetrável, não apenas para Frédéric mas também para Organte (ao menos é o que Frédéric pensa): “Ces gestes clairs et simples étaient par essence impenétrables et glissants, ils ne se concevaient que par les mystères du principe d'individuation, ils ne pouvaient être que parce que, dès l'origine, Cosime était une autre que Frédéric, irréparablement une autre ${ }^{\text {} 74}$.

É assim que Frédéric vê Cosima e é nesse mundo do irreparavelmente outro que ele tenta penetrar, que tenta compreender. Cosima e Frédéric se aproximam, passam a conviver e ele penetra, ao menos momentaneamente, no mundo de ilusões e contos de fada em que ela vivia, com ela quase sempre inventando histórias, o que não o satisfazia de maneira alguma (o que o jovem desejava era seu corpo, a carne de Cosima, o que sabia que não conseguiria... e por isso esse jogo de histórias tristes inventadas era um modo artificial e angustiante de compensar seu desejo).

Um dia do mês de julho Frédéric vai à casa de Organte e recebe a inesperada notícia de que a família iria viajar, passar as férias em Nice para a melhor recuperação de uma das filhas de Cosima, que estava doente. Frédéric não esperava por isso, já que Organte lhe dissera que ficaria em Paris para terminar seu livro sobre Michelângelo.

\footnotetext{
${ }^{74}$ IBIDEM - p. 272.
} 
Ambos se despedem com tristeza e se Frédéric esperava ser convidado para se juntar à família na viagem, esse convite não é feito. Richard Organte viaja quase que imediatamente e sozinho, a fim de encontrar as acomodações necessárias. E dois dias depois, Cosima iria com as filhas ao encontro dele, mas antes Frédéric vai à casa para se despedir da mulher que já admitia (para si mesmo) amar.

Na despedida, Frédéric diz a Cosima que ela se divertirá em Nice enquanto ele ficará entediado em Paris e ela lhe responde que escreverá e que é com pena que o deixa, mostrando que até tinha "brincado" com uma história que eles não mais se veriam. Frédéric pensa então que nada passara de um jogo para Cosima, que tudo que ela fazia era apenas uma brincadeira para criar e alimentar sua melancolia e em nenhum momento levou em consideração a sinceridade com que Frédéric sentiria sua falta. E isso é confirmado no momento em que ela diz que sua relação com o jovem fora não só um "jeu de tristesse” mas também um “jeu de amour”, o que faz com que Frédéric vá embora feliz e ao mesmo tempo indignado.

O narrador então interrompe a narração dizendo que é o fim do período feliz e que agora, na segunda parte do livro, falará das infelicidades de Frédéric.

Temos, então, o fim de uma história, de um fracasso: sua relação com Organte não foi a esperada (aos poucos esse mostrava sua indiferença, seus meios burgueses e após a viagem, afasta-se ainda mais) e não conseguira ter nenhuma relação mais consistente com Cosima senão a do fingimento, do jogo. Tudo fracassara, até mesmo os escritos de Frédéric sobre suas conversas com Organte (este, por meio de uma carta, diz não se reconhecer nas idéias que Frédéric diz que ele tem, e pede para não publicar o texto).

No entanto, o último fragmento do texto nos deixa ver que nem tudo é fracasso e perda, ou que esse fracasso traz consigo uma vitória: "Les derniers mots d'une défaite: Nous pouvons le laisser sur cette défaite, sur cette fructueuse défaite. Il est humilié, désespéré. Il va longtemps douter de lui, il pensera perdre sa force. Il est tout seul, il méprise les hommes et il a peur des femmes. Tout ce qu'il chérissait, le clair soleil, les parfuns, les pensées fortes, le goût salé de la vie, va lui faire horreur. Mais le temps approche où il ne connaîtra plus que des victoires" ${ }^{\text {,75 }}$.

O fracasso não parece ser total. Diferente dos personagens de Malraux, Frédéric se lança em uma aventura e fracassa, mas esse fracasso será transformado por

\footnotetext{
${ }^{75}$ IBIDEM - p. 286.
} 
ele em vitória. Se os personagens principais dos textos de Malraux venciam a aventura mas essa vitória nada lhes significava ou nem mesmo era reconhecida por eles, o personagem principal de Sartre nem chega a vencer (apenas em L'ange du morbide há a conquista e depois a derrota da vitória): Frédéric não consegue fazer de Organte seu mestre, não conquista o amor de Cosima (na verdade nem tenta, por saber improvável) e enfim, não obtém a aceitação dos seus escritos de Organte (do mesmo modo como Malraux teria recusado o texto de Sartre?). O fracasso se encontra freqüentemente presente na obra dos dois autores analisados por nós; mas se em Malraux tanto a vitória quanto a derrota se igualam na indiferenciação, se o fracasso revela a insignificância de todos os atos, em Sartre a frustração é totalmente significativa: Frédéric sofrerá as perdas, sentir-se-á humilhado e inseguro, mas "le temps approche où il ne connaîtra que des victoires". A vitória aparece para Frédéric sobre o fundo do fracasso, este desvela o ganho que toda derrota traz consigo, e isso pode ser verificado não só por essa frase citada acima (que poderia ser apenas irônica) mas também pelo nome dos dois últimos capítulos anotados e não escritos por Sartre: "Michel-Ange" e "Empédocle", o que indica que os livros esboçados respectivamente por Organte e Frédéric seriam escritos ${ }^{76}$. E é a essa conclusão que Rybalka e Contat chegam na introdução à Une défaite, em Écrits de Jeunesse:

Le roman constate une double et même triple défaite: Frédéric n'a pas trouvé de maître, il a échoué avec Cosima et son livre sur Organte a été rejeté. Mais il a en réalité joué à qui perd gagne et ses souffrances n'ont pas été inutiles: il reste seul mais il a fait une double expérience, celle du tragique et celle de l'écriture. Les titres des deux derniers chapitres suggèrent qu'Organte a mené à bien son Michel-Ange et que Frédéric a écrit son Empédocle. L'aventure de Frédéric avec Organte et Cosima a ainsi abouti à deux livres ${ }^{77}$.

Temos aqui esboçado um "quem perde ganha" sartriano, o que parece ser o contrário do que Malraux mostra por meio de seus escritos literários (um "quem ganha perde" ou uma insignificância e frustração total). Frédéric perdeu, mas sua derrota não trouxe insignificância de todas as ações: depois do período de sofrimento e luto, ele encontrará outras mulheres e escreverá outros livros, vencendo e perdendo

\footnotetext{
${ }^{76}$ Frédéric projetara escrever dois livros: um com Organte, o qual não foi aceito por este - e um sozinho, que se chamaria Empédocles.

${ }^{77}$ SARTRE. Écrits de Jeunesse - p. 203.
} 
novamente. Ao menos dessa derrota ficará um registro literário (como mostram Jésus la Chouette e La Semence et le scaphandre), o que não é pouca coisa. Se lembrarmos que a escritura não vale nada mas que nada vale a escritura, esse resquício da derrota registrada literariamente vale tudo.

A literatura, para Sartre, pelo menos no que vimos até aqui, está diretamente ligada ao real e não permite um fantástico que se volta expressamente contra o concreto, como é o caso de Malraux. Mas, estranhamente, Sartre tem um conto que parece ser também guiado pela fantasia, por um armênio que vê o futuro e o mundo dos deuses. Vejamos como nosso autor-filósofo escreve seu conto mais fantástico, $E r$, l’arménien.

\section{Er, l'arménien}

Esse conto trata de uma família mitológica da qual Platão (em A República) fala. Er é, segundo Sartre, o último representante dessa família que costumava morrer e ressuscitar a seguir, contando então os conhecimentos que obtivera no mundo dos deuses. Estamos, pois, no terreno do clássico, no terreno do mito ${ }^{78}$, o que nos afasta bastante dos outros contos escritos por Sartre até aqui, tão próximos aos acontecimentos vivenciados por ele.

No entanto, logo no início do texto Sartre falará que esse armênio Er do qual contará a história é um contemporâneo dele, o que já implica uma quebra no mito da retórica antiga. Além disso, escrito em 1928, o texto faz referência aos armênios, talvez como modo de mostrar ciência do massacre ocorrido em 1915 na Armênia, quando os turcos invadiram o país, provocando uma fuga em massa dos armênios até a França.

Se Sartre parte da mitologia e da literatura clássica, ele não se restringe a ela, dizendo, desde o início, que se trata de uma história contemporânea, que se passa nos dias em que o autor escreveu o livro. Como diz Geneviève Idt, há três maneiras de ser mitólogo: a primeira seria a prática da retórica antiga (de tomar o lugar comum de forma muito séria), a segunda (adotada por Flaubert), desconsidera as opiniões recebidas opondo uma à outra sem concluir por nada. E a terceira maneira seria a adotada por Sartre e "elle consiste, comme dans l'activité passive, à reproduire les lieux communs, mais aussi à les situer socialement, à en designer l'origine, en prenant

\footnotetext{
${ }^{78}$ da narrativa de uma criação, da origem fundadora dos mitos. Para ver o significado do mito no teatro sartriano, cf. SOARES, C. Sartre e o pensamento mítico.
} 
la responsabilité d'un tel travail, en opérant un choix, en refusant l'idée d'un consensus social, ou en d'autres termes d'une idéologie dominante homogène" ${ }^{79}$.

Mesmo o fantástico e o mitológico são, em Sartre, situados no tempo e no tempo presente (talvez já mostrando o que Sartre fará em As moscas, recuperando o mito de Orestes para falar do povo francês sob a Ocupação Alemã, aqui ele recupera o mito de Er, retratado em Platão, para falar de temas e questões que lhe são essenciais, como a questão da Contingência, do Bem e do Mal, da Liberdade).

Er, o contemporâneo, morre e no terceiro dia ressuscita, lembrando a todos que isso era típico da família (exceto seu avô e pai, que morreram sem ressuscitar) e que no dia seguinte, após descansar, iria à praça pública contar o que lhe acontecera. Nesse dia várias pessoas se reúnem para ouvi-lo falar e ele introduz sua narração falando de sua vida, de sua infância (da vergonha que tinha do pai por ele não ter ressuscitado, como todos os homens da família), de como percebeu que os homens se contentavam com uma vida autômata que não permitia nem mesmo pensar: "Je me figurai la plupart des hommes réunis dans un vaste et triste atelier, les mains occupées à quelque labeur qu'ils ne comprenaient pas, n'aimaient pas, les yeux détournés de leur tâche grands ouverts, fixés droit devant eux comme pour voir à travers les murs leur Bonheur futile, cette chimère de repos, d'arrêt, cette mort consciente" ${ }^{80}$. Diante dessa constatação, Er decide se separar da amada, livrar-se da felicidade que tanto o fez sofrer, e buscar um novo objetivo, mesmo que para isso tenha que criá-lo artificialmente: "Restait à la [morale] construire et à en trouver les premières maximes, fictions ou vérités" ${ }^{\prime 1}$.

Para fugir da moral constituída, que impõe a busca da Felicidade fútil, sinônimo de morte consciente, é necessário construir uma outra moral, mesmo que ela seja ficção. É necessário que as novas máximas sejam criadas pelo próprio autor, que ele as invente e as sancione como máximas, o que é angustiante e desesperador, pois mostra que nada permite ao homem se decidir por uma ou outra escolha: "J'en avais une sorte de désespoir car je sentais bien qu'enfin il me faudrait tirer mes principes de moi-même et je n'avais plus confiance en moi" ${ }^{\prime 2}$. A fonte dos princípios não deve estar baseada na ciência nem em regras: ela deve ser buscada por cada um - e isso não

\footnotetext{
${ }^{79}$ IDT, G. "Sartre mythologye: du mythe au lieu commun" In LOUETTE. Autour de Jean-Paul Sartre: littérature et philosophie - p. 133.

${ }^{80}$ SARTRE. "Er l'arménien" In Écrits de Jeunesse - p. 299.

${ }^{81}$ IBIDEM - p. 301.

${ }^{82}$ IBIDEM - p. 304.
} 
deve ser entendido de modo psicológico, como se houvesse algo dentro de cada um que o impulsionasse a uma escolha, mas sabendo que Nada inclina-o mais a uma escolha que à outra, que ele tira os motivos e justificações de si mesmo - é ele quem irá escolher seus motivos, aliás, escolher uma moral é ao mesmo tempo escolher suas justificações. No ato mesmo em que se inventa uma moral, inventa-se qual o motivo que será adotado. E saber-se como o criador absoluto da moral só pode ser desesperador e angustiante, pois revela a liberdade que somos e a contingência essencial de nossas ações (na medida em que nada nos impele a uma escolha, vemos que tudo é contingente e que somos nós, livres portanto, que devemos escolher) ${ }^{83}$.

Era nisso que Er pensava quando "morreu" em um bordel, simbolizando que uma vida de amor (a que ele tinha antes) deveria encontrar seu fim em uma morte amorosa. Ele morre e sonha com uma noite escura que se mostra uma Natureza que grita, denunciando, assim, a existência dos deuses ${ }^{84}$. É na companhia da Natureza nessa noite escura, livre de tudo que é físico e necessário (a ciência, a evidência), que Er escuta uma voz que lhe dá as boas-vindas e diz que os deuses responderão ao que ele deseja saber, desde que seja uma questão clara, feita com precisão. Er, após pensar e se livrar do temor religioso que essa voz lhe inspirava, fala que deseja conhecer o que é o Mal.

Ao pronunciar esse desejo, Er é levado a um Titã, Briarée, que responde simplesmente que o Mal não existe, resposta essa que Er estranha, já que pensava ter sido levado até Briarée porque este muito tinha sofrido e sabia o que era o Mal. Mas Briarée o surpreende e apenas responde, novamente, que ná há o Mal.

O conto é cortado (não temos o conto terminado, apenas fragmentos juntados por Contat e Rybalka), o diálogo entre Er e Briarée é abruptamente encerrado (abandonado seria melhor dizer) e temos diante de nós um novo diálogo, agora entre Prometeu e Ichtyos, falando sobre o mesmo tema: Deuses, o Bem, o Mal, e após um diálogo socrático (com Prometeu dirigindo a conversa) eles chegam à conclusão de que “Si Dieu est libre, il ne peut y avoir que du Bien, si Dieu n'est pas libre, il ne peut

\footnotetext{
${ }^{83}$ Essas questões serão tratadas em $O$ ser e o nada, mas aqui, pelo relato de Er, já podemos ver a angústia do homem que se compreende como livre, sem justificativas e, portanto, como criador de sentidos e de uma moral.

${ }^{84}$ As descrições dessa visita aos deuses no conto de Sartre é oposta à de Platão. Para uma comparação entre as duas histórias, ver SOUZA, T. O mito de Er: Sartre e o platonismo às avessas? IN Cadernos de ética e filosofia política, v. 8, 2006.
} 
y avoir ni Bien ni Mal”85. Prometeu mostra que é o homem que julga o Bem e o Mal, e que, portanto, não há Mal nem Bem no mundo.

Através desses diálogos, Er percebe que essa moral imposta não tem sentido nem mesmo se considerada como obra dos deuses - e a partir do momento em que se deseja lutar contra um dos dois (ou a moral já sempre determinada, ou contra os deuses), é necessário lutar contra o outro.

À existência dos deuses não é possível combinar a arbitrariedade e contingência dos valores. E é exatamente isso que Briarée volta a falar para Er após o diálogo entre Prometeu e Ichtyos. Briarée narra a história de uma jovem que conhecera e amara, mas que fora tomada por uma doença, a qual a mataria em no máximo dois anos. Um dia, saindo para passear, a moça morre: "Eh bien ce jour-là j'ai pressenti l'affreuse vérité que tu m'as révélée: non il n'y a pas de Mal, pas de Destin. Cet accident stupide ne pouvait venir d'un Esprit malin, puisqu'elle était condamnée. Une intelligence, quelle qu'elle fût, n'aurait pas commis cette faute de méthode: il y avait trop, trop de moyens employés pour arriver à cette Mort” ${ }^{\circ 86}$.

A fatalidade e o destino são ilusão, um reconforto para aqueles que têm medo de enfrentar a moral constituída e os deuses. O relato de Briarée, que poderia ser interpretado como a fatalidade máxima (tendo a morte já decretada, mesmo assim o Destino ironicamente intervém para mostrar que é o senhor da situação - do mesmo modo que ocorre em $O$ muro, conto no qual a fatalidade pode parecer fundamental mas que mostra, na verdade, o império da contingência e do acaso), mostra o quanto tudo é contingente, que até mesmo o destino, se existisse, o seria também (assim como os deuses). A contingência é a única necessidade de que dispomos, já que nossa liberdade nos é um fardo do qual não podemos nos libertar.

Por fim, é Apolo quem fecha o diálogo com Er, o armênio, falando de moral e de arte. Vejamos a que conclusão ele chega:

Une morale, quelle sottise! Mais conserver le désir de créer une oeuvre d'art, en chercher dans toutes les minutes, dans toutes les circonstances, les matériaux, traîner son corps aux quatre coins du monde, dans la douleur, dans la luxure, des lits de rose, dans la merde pour amasser ces matériaux, mais les transformer à chaque instant par un puissant effort de sa pensée; abandonner sa loque au hasard, et ne rien laisser au hasard; se

\footnotetext{
${ }^{85}$ SARTRE. "Er l'arménien" In Écrits de Jeunesse - p. 319.

${ }^{86}$ IBIDEM - p. 325.
} 
protéger des passions par un désir plus violent qu'elles toutes, par la passionmère elle-même, et pourtant céder à toutes, jouer avec elles comme avec de jeunnes fauves, s'oublier tout entier alors qu'on plonge le plus avant en soimême, voilà ce que je propose ${ }^{87}$.

Apolo propõe a Er que a busca por uma moral é uma besteira, ao menos no sentido de ter uma moral fixa - a única maneira de obter qualquer moral é criando-a, imaginando-a, assim como a obra de arte. E que esta pode ser luxúria e cama de rosas, mas que para isso é necessário também mergulhar na dor e na merda: a arte é a confluência desses dois meios opostos, não é nem apenas um bonito e abstrato sobrevôo nem simplesmente a feiúra do concreto frio e sujo. A ficção deve conter em si as contradições da qual é fruto: o abstrato e o concreto, a cama de rosas e a merda, a luxúria e a dor, o necessário e a contingência (abandona tudo ao acaso sem deixar nada ao acaso), a proteção das paixões pela própria paixão... enfim, a arte é e mostra as contradições que o próprio homem é.

E fazer isso não é, segundo Apolo, ser esteta, seguir uma estética já constituída - não se trata de trocar a moral feita por uma estética também já fixada. É por isso que Apolo adverte Er:

$\mathrm{Ne}$ crois point que je veuille faire de toi un esthéte. Celui-là cherche l'Art déjà fait, croit trouver des tableaux, des intrigues de roman partout: 'Ah ma chère, c'était à peindre'. Toi, tu seras un ouvrier patient et un martyr. Tu sauras que rien n'est beau sauf ce que font les hommes, que tout est à faire, que la vie à elle seule ne t'apprendra rien, que tu dois prêter, donner, toujours donner, aux choses, aux hommes, et que ton vrai but, c'est le livre, le tableau, la statue qui naîtront sous tes doigts ${ }^{88}$.

Nem a moral nem a arte são já construídas: tudo está por fazer e é o homem (sem a ajuda da ciência, já descartada desde o início) quem as fará: é a ele, à sua liberdade, que resta construir e dar sentido às coisas, aos homens, à moral e à arte. Ser artista, buscar o sincronismo entre as rosas e a merda é ser um trabalhador paciente e um mártir, é construir suas obras e o próprio homem, é construir uma estética a cada momento, o que já é e sempre é uma moral em construção.

\footnotetext{
${ }^{87}$ IBIDEM - p. 330.

${ }^{88}$ IBIDEM - p. 330.
} 
Não cabe pedir ajuda aos deuses, à moral admitida e aceita por todos, nem a uma estética já feita: o homem está só em sua construção perpétua - e se isso é motivo para angústia e temor (já que o homem não tem em que se apoiar), é também a demonstração mais concreta e cruel que se pode ter da liberdade humana.

É desse modo que o conto sobre Er termina. Diante da proposta de Apolo, Er tem medo (acha-a linda, mas incapaz de realizá-la), já que é preciso ter muita força e confiança em si para não fracassar nesse projeto - mas Apolo olha Er e lhe diz que não é necessário temer. E o mesmo se dá com todos os homens: tarefa árdua e pesada essa, mas que todos - quer queiram ou não - devem suportar. Esse é o único destino do homem: ser livre, criar o mundo e se criar no exercício (mesmo que frustrado) de liberdade, do qual não chega a diferir.

Sartre retoma o conto narrado por Platão no livro X da República para inverter o que o filósofo diz. Se nesse livro a questão tratada é justamente a da expulsão do poeta e de toda arte da cidade (por ser inútil e perigosa, por fazer o homem se contentar com a cópia da cópia e não mais buscar a Idéia), assim como a da descoberta do Bem e do Mal, das virtudes que devem ser racionalmente buscadas (pelo que Er narra de sua ida ao mundo dos deuses, com cada alma escolhendo seu destino e com a "conclusão" de que se deve escolher com calma, pensando racionalmente no "equilíbrio", na eliminação das paixões), Sartre utiliza o mesmo conto para concluir o contrário: essa busca racional e lógica, apoiada nas ciências, na matemática, ou em qualquer outro porto seguro (a religião, por exemplo) não leva a nada: a moral deve ser inventada pelo homem; é ele quem cria e dá significado às suas criações e deve, a todo instante, a cada momento, reinventá-las e destrui-las.

Esse conto já contém, portanto, alguns temas que estarão sempre presentes na filosofia de Sartre, como o da liberdade humana que transforma toda e qualquer necessidade (ciência, deuses, moral, estética) em contingência, e o da angústia do homem livre. E se a forma se diferencia um pouco da dos outros contos (mais fictício, recorrendo ao mito), o conteúdo continua o mesmo: a ironia do homem perante si próprio, a crítica realizada em relação aos que buscam se apoiar em uma moral e estética constituídas e fixadas... a auto-crítica sempre presente, e a descrição do homem como ser frágil e poderoso, como "ser" que se constrói ao assumir-se como inacabado (totalidade não totalizada) e contraditório. É sobre isso que os contos de Sartre tratam, e essa revelação se estende à própria arte, já que ela é uma obra 
humana: no ato mesmo de escrever, uma estética em construção se desvela, e essa é uma estética que se mostra mergulhada nas rosas e na merda, na luxúria e na dor, devendo ser ela mesma essa contradição sem síntese que o homem é; assim, essa estética sartriana revela uma ética, uma ética sem regras e valores, uma ética que mostra o homem livre a se constituir sem nunca chegar à sua constituição final, enfim, uma ética que também deve ser a cada instante construída e demolida.

\section{Conclusão}

Tendo visto os contos de Sartre e Malraux de modo mais detalhado, mostrando qual o papel da arte e da ação nas obras, e tentando compará-los com o modo como o autor pensa a arte na época, podemos, agora, mostrar as semelhanças e diferenças que permeiam as obras desses dois autores.

Como já dissemos no início do capítulo, nossos autores mostram influências de personagens opostas, o que já nos começa a indicar que se Malraux parece pensar que a arte é um fantástico que, embora ligada ao real, deve tematizar a separação em relação a este, Sartre parece pensar, por sua vez, que a obra de arte está muito próxima do real e que sua função é justamente criticá-lo por meio da ironia.

E a forma dos textos se assemelha às influências que escolheram sofrer: tanto os cenários quanto os personagens de Malraux são ao mesmo tempo muito fantásticos (o músico que se transforma em balão e depois em Pecado) e permeados por figuras geométricas, por descrições de formas cônicas, quadradas etc. Pelo menos em seus dois primeiros contos Malraux está muito preso à influência de Max Jacob, e é só no terceiro conto (La tentation de l'Occident) que o escritor recorrerá aos cenários e personagens menos fantásticos. Se o fantástico impera em seu primeiro conto, ele vai, aos poucos, cedendo lugar para o "real”, para uma ficção que não pareça totalmente desvinculada dos acontecimentos reais.

Para Sartre o caminho é exatamente o inverso: partindo do realismo ingênuo de Mirbeau, sua ficção não se distingue muito de uma autobiografia ${ }^{89}$. Seus personagens são semelhantes ao próprio autor e às pessoas que o rodeavam, seus cenários são parecidos com os que conheceu e vivenciou. Mas Sartre também vai, aos

\footnotetext{
${ }^{89}$ E a autobiografia propriamente dita, Les Mots, apresentará mais preocupação literária que esses contos iniciais.
} 
poucos, distanciando-se desse realismo um tanto grosseiro. Embora possa-se achar alter-egos em quase todas suas obras de ficção, e seus temas continuem a ser muito próximos do real, sem distorcê-lo muito, o imaginário se desvincula dessa vivência ocorrida, do "retrato" do real. Sartre aos poucos sai desse real retratado para um imaginário, para algo que se aproxima mais da ficção que do diário.

Em relação à forma e estrutura das obras podemos dizer então que os dois autores partem de posições antagônicas e aos poucos vão se encontrando, abandonando suas influências e partindo um em direção ao outro, com Malraux adotando cada vez mais cenários, personagens e temas próximos ao reais e com Sartre permitindo que o imaginário e a preocupação com o estilo façam realmente parte de suas ficções.

Mas se a forma aparece inicialmente de forma antagônica e extrema em Malraux e Sartre, o mesmo não se pode dizer em relação aos temas, aos conteúdos narrados. Aqui parece haver uma semelhança grande entre eles, mas uma semelhança que revela uma distinção radical, a qual pensamos que permanecerá mesmo nas obras futuras e principais de ambos os autores.

A aventura é, em boa parte, o tema dos contos de Malraux e Sartre. Seja de modo fantástico ou real, aventura grande ou pequena, de seres imaginários ou de homens comuns, é ela que vemos em todos os contos analisados. Em Malraux ela está presente nos Pecados que desejam matar a Morte (Lunes en Papier), no músico Pompier que enfeitiça e aprisiona a serpente Clave de Sol (Écrit pour un idole à trompe), e mesmo nos dois jovens que viajam, um para a Europa e outro para a China (Tentation de L'Occident). O mesmo se dá em Sartre: embora suas aventuras sejam mais cotidianas e menores, como o caso dos jovens que fundam uma revista ( $L a$ semence et le scaphandre), há sempre uma busca a empreender, algo a enfrentar. $\mathrm{O}$ professor e sua família buscam o reconhecimento em volta a adolescentes que fazem algazarras na aula e a uma sociedade que mal espera para revelar sua realidade e crueldade (Jésus la Chouette), outro professor deseja encontrar o mórbido e por isso começa a namorar uma tuberculosa (L'ange du morbide) e até mesmo Er, saído de Platão para nossos dias e relatando sua grande aventura com os deuses... esses são os temas dos contos de Sartre.

No entanto, embora ambos retrarem as aventuras de seus personagens, eles o fazem de maneira diversa. Para Malraux a aventura parece ser uma necessidade séria, que deve ser respeitada e empreendida, enquanto para Sartre a aventura parece ser 
também uma necessidade, mas uma necessidade da qual é preciso zombar, a qual é necessário criticar e ridicularizar. A aventura, necessária para ambos, é, no entanto, estimada por Malraux e ironizada por Sartre.

A diferença no modo como os dois vêem a aventura não se dá porque ela é vitória em um e fracasso no outro - tanto em Sartre como em Malraux há sempre uma certa frustração frente aos resultados da aventura. É o próprio ato de aventurar-se, de tentar alcançar seus objetivos, necessário para ambos os autores, que é visto com seriedade por Malraux, como algo a ser buscado e seguido, e com ironia e crítica por Sartre, como algo que, embora necessário, não deve ser levado a sério (e que não há diferença, por exemplo, entre a aventura pelo mórbido ou pela Legião da Honra).

E se dissemos que a aventura é sempre frustrada para ambos os escritores, ela não o é, porém, da mesma maneira. Nos contos de Malraux os personagens principais (do ponto de vista do qual a história é contada) sempre vencem o desafio que se propõem, os adversários que enfrentam; enquanto os personagens de Sartre nem sempre vencem. Mas a vitória sempre presente em Malraux é uma vitória amarga, ou efêmera ou que nem mesmo se reconhece como vitória: é o caso, por exemplo, dos Pecados que, após terem matado a Morte (objetivo deles), começam a chorar porque já nem sabem mais por que a mataram. E se por um lado a vitória perde sua significação, passa a ser acompanhada de paralisia e choro, a derrota também já não significa muita coisa: todos os adversários derrotados não sofrem por isso, eles ficam indiferentes (como a Morte que, sabendo que está sendo morta no banho de ácido preparado pelos Pecados, continua na banheira) ou até mesmo dormem, como se nem percebessem que perderam. Os personagens de Malraux sempre realizam aventuras, vencem-nas mas a vitória traz consigo a frustração, a apatia.

Já em Sartre a aventura não leva sempre à vitória mas a perda não causa uma tal apatia. Mesmo que a aventura leve a uma vitória que também nos aparece como frustração, essa frustração não é sinônimo do que vimos em Malraux. É certo que seja o professor que alcança seu objetivo de reconciliar-se com o mórbido por meio de um namoro com uma tuberculosa (L'ange du morbide), seja Frédéric que não consegue conquistar Cosima nem mesmo lançar seu livro com o mestre Organte (Une défaite), sempre há frustração. O professor que vence se frustra por ver que o mórbido real lhe causava horror, o jovem que não conquista a amada e não publica o livro junto de seu mestre se frustra justamente por isso, mas em nenhum deles há uma paralisia total, um choro que chega a tornar a vitória e a derrota insignificantes. Eles não se satisfazem 
com a vitória ou a derrota, e nisso há semelhança entre Malraux e Sartre, mas também não tornam a aventura destituída de sentido. O professor, após a vitória fracassada de seu desejo, decide mudar seu modo de vida, no que será igualmente ridicularizado pelo narrador: mas o que nos importa inicialmente é que o professor age depois dessa frustração. $\mathrm{O}$ mesmo se dá com Frédéric, o jovem que viveu uma aventura com o mestre Organte e com a mulher deste, Cosima, mas que fracassou em ambos os projetos e se frustrou por isso: o conto termina com a indicação de que o jovem sofreu mas voltaria a conhecer a vitória. Embora aqui a ação após a frustração não seja narrada, ela é indicada pelo final e também pelos títulos dos capítulos que viriam a seguir (e que não foram escritos), nos quais mostra-se que Frédéric viria a escrever um livro.

Os personagens de Sartre fazem a aventura e sempre se frustram na vitória e na derrota, mas não importa: diante dessa frustração é preciso agir, é preciso fazer algo, nem que seja renunciar ao desejo anterior e adotar uma vida burguesa comum, ou então esperar um tempo e lançar-se novamente no desejo de escrever.

E é isso que não vemos em Malraux: seus personagens sempre vencem e se frustram com a vitória, e mesmo que recomecem a aventura (no caso de Pompier), o fim do conto será sempre a frustração e a apatia, o choro. Seus contos terminam sempre de modo pessimista, de modo a enfatizar a frustração; enquanto nos contos de Sartre há um certo otimismo, derivado não da esperança de vencer, mas da posssibilidade e mesmo necessidade de agir, malgrado a frustração, ou justamente por causa dela. O modo como cada escritor descreve o fracasso de suas aventuras se relaciona diretamente com a maneira com que descrevem os valores em seus contos.

Em todos os contos de Malraux há a constatação de que Deus morreu ou foi substituído sem nem mesmo perceber - o Pecado Orgulho, o Charlatão e mesmo o Diabo fazem esse diagnóstico de que Deus perdeu seu lugar e que desde então, todos os atos extravagantes são possíveis e todas as ações se equivalem. Em um mundo em que Deus está morto, ou pior, caducou, a moral deixa de ter sentido: os homens perdem todos os seus valores e vivem no caos absoluto da falta de uma moral e da noção do que é ser homem - após ter matado Deus para conhecer sua imagem, o homem ocidental se horroriza e percebe que não é possível conviver com ela. Temos então um homem que se busca, mata Deus, relativiza totalmente as noções e valores, mas não consegue viver desse modo. Vivemos em um mundo caótico, no qual não é 
mais possível encontrar apoio nem referência, e esse mundo foi provocado pelo próprio homem. E se é esse o diagnóstico apresentado por Malraux, como a vitória poderia ser considerada com alegria e como significativa? A vitória e a derrota nesse mundo em que tudo perde seu valor só podem encontrar-se de modo indiferenciado. Não se pode atribuir valor à vitória nem à derrota. Ou melhor: não há valor na vitória nem na derrota, mesmo porque vivemos no mundo da falta de valores. É por isso que os personagens de Malraux dormem indiferentes quando perdem e choram paralisados quando vencem: no mundo sem valores não se pode dar valor à vitória ou à perda.

E se o mundo no qual Malraux e Sartre vivem é o mesmo (França no começo do século $\mathrm{XX}$ ), eles não o vêem, porém, do mesmo modo. Para Sartre não há a questão metafísica da perda dos valores e da insignificância total dos atos humanos. Nos contos de Sartre temos acontecimentos mais cotidianos nos quais não cabem esse diagnóstico geral do "homem ocidental europeu". Temos um professor, alguns jovens lançando revistas, outro que deseja lançar um livro - e em todos esses a vitória ou derrota da aventura não o levam a uma apatia total, a uma insignificância de seus atos - esses são válidos ao menos pela experiência. E no único conto em que a questão dos valores e da moral é tratada diretamente, em Er, l'arménien, é para mostrar que a moral está presente na vida do homem como uma tábua de valores que deve ser quebrada (isso parece ser positivo nos contos de Sartre, mesmo que leve ao abandono e ao desespero, enquanto em Malraux há sempre a ênfase no aspecto negativo dessa questão). E se é certo que quebrar essa moral constituída leva à angústia, é só ela que possibilitará ao homem ver que, no fundo, toda moral é inventada, criada tal como uma obra de arte. Cada ato deve estabelecer o processo criador dos valores, o qual não deve, no entanto, ser finalizado, concluído. E se é assim, o homem não deve se tornar apático nem deixar de agir perante a constatação de que não há valores definidos - ao contrário, essa constatação deve ser vista como um estímulo à ação humana, já que é só ela que justifica e dá sentido à existência de cada homem. É por isso que os personagens sartrianos não ficam paralisados pela vitória vã ou pela derrota - em todos os contos aqui vistos, há pelo menos uma indicação de que eles voltam a agir, seja para negar a busca anterior, seja para continuá-la.

Assim, se a constatação é a mesma - há no mundo uma falta de valores, o abandono de uma moral constituída - Malraux vê nela a explicação do desespero e insignificância dos atos humanos, os quais devem ser seriamente combatidos por meio de uma busca pela nova noção de homem; e Sartre vê nessa descrição também a 
explicação de um desespero, mas de um desespero libertador, que mostra ao homem que é ele - e apenas ele - que deve criar sua moral (não como regras de valores, mas como exercício ético que não deve findar-se, acomodar-se). E é diante dessa constatação atual do mundo caótico e desordenado que ambos pensam o papel da arte.

Esse mundo sem valores é preciso enfrentar. Para Malraux é necessário sair desse caos e encontrar uma nova noção de homem. Como porém encontrar essa noção se estamos inseridos nesse mundo caótico? Apenas enfrentando esse real, negando a desordem, é que se pode pensar na construção de um novo mundo no qual uma nova moral e uma nova noção de homem possam ser encontradas. E quem tem o poder de se contrapor ao real dessa forma é, para Malraux e seus personagens, a arte e a aventura. E a função dessa arte é justamente a de enfrentar o mundo real, de lutar contra ele e indicar, através do fantástico ordenado, a nova noção de homem. Só fugindo do real por meio de um imaginário que nos traz ordem e regra é que podemos sair do caos institucionalizado e buscar uma nova noção de homem.

E se Malraux vê na arte a resposta para sua descrição do mundo sem valores, Sartre também dota-a de uma grande importância, embora de modo distinto. O filósofo não chega a colocar a obra de arte como salvação, como adversária do real ${ }^{90}$, mas dá a ela o poder de desvelar e criticar a sociedade na qual vive. Por meio do realismo um tanto grosseiro de seus contos iniciais, a arte reflete (não como espelho fiel, mas como espelho que distorce, que critica) o mundo real e os desejos burgueses de orgulho, satisfação e plenitude, de modo não só a possibilitar que os leitores se vejam nesse reflexo mas também que possam (e devam) refletir sobre isso. Mesmo para o jovem Sartre a arte não se encontra no mundo totalmente irreal, abstrato e fantástico. Como o conto Er, l'arménien nos mostra, a arte é vista como uma mistura de rosas e merda, luxúria e dor, não se restringe ao real por ser rosa e luxúria, mas está mergulhada no real, em sua merda e dor. Desse modo, e como o jovem Sartre pensa junto com seu amigo Nizan, a arte deve mostrar o homem atormentado pelo Mal, mergulhado na lama - e essa revelação é feita não porque a arte e o artista estão totalmente fora dessa lama, mas porque estão ao mesmo tempo fora e mergulhados nela (é a luxúria, mas também a dor).

\footnotetext{
${ }^{90}$ Nesse momento sua teoria do imaginário ainda não foi escrita, mas já aqui a arte é negação do real que se faz a partir do real e se volta para ele - e portanto, se a ilusão é buscada por aqueles que escrevem, ela só é alcançada na má-fé. A arte não possibilita autenticamente essa "salvação".
} 
Como não há aqui aquele diagnóstico geral de Malraux sobre a perda dos valores do homem ocidental europeu, a arte também não é vista como confronto e como uma possível resposta, mas para Sartre ela também exerce um papel fundamental de desvelamento e crítica, mostrando ao homem que é ele quem cria, seja a arte seja a moral seja ele mesmo, e não a partir de noções abstratas mas da própria lama, das próprias ações que faz - e que por isso não se pode deixar de agir, de construir-se.

De todo modo, a arte, tanto para Malraux quanto para Sartre, é essencialmente crítica. A obra de arte, para ambos, tem o papel de criticar o real ou de possibilitar sua crítica. Seja por meio de um fantástico exagerado, seja por meio de um realismo também ingênuo, tanto Sartre como Malraux pensam que a arte é fundamental para que uma crítica seja possível e efetiva. Assim, arte e crítica parecem ser indissociáveis.

Mas a maneira como cada autor pensa e exerce essa crítica por meio da arte nos leva diretamente a uma atitude ética. Pensar a arte como crítica é não desvinculála totalmente de uma ética. Não estamos falando aqui de uma ética panfletária, de uma arte que estaria a serviço de algum partido ou concepção político-religiosa, mas de uma atitude frente às questões de seu tempo. Pensar na arte como desvelamento e/ou confronto em relação ao real é exigir um posicionamento, uma atitude em relação ao mundo e aos acontecimentos. E é por isso que pensamos que a teoria estética revelada por Malraux e Sartre por meio de uma análise compreensiva de suas obras literárias e de seus textos sobre a arte não só deixa ver como exige uma atitude ética, a qual estará de acordo com o modo como cada um enxerga e exerce sua literatura (não pretendemos aqui determinar se a estética determina a ética ou se é o contrário. Longe de uma análise determinista e psicológica da relação entre elas, desejamos apenas atentar para o fato de que há pontos em comum entre o modo como cada um exerce e concebe sua arte e o modo como pensam a ação do homem no mundo).

E se a concepção da arte como crítica é comum a ambos, o que nos possibilitou fazer a relação entre o imperativo estético e o imperativo ético, não é verdade, porém, que Malraux e Sartre vêem essa crítica do mesmo modo, e é essa divergência entre os autores que os levará a manter também uma distinção fundamental no plano das atitudes em relação aos fatos de suas épocas.

Para Malraux, a crítica pela arte é essencial mas deve ser feita de modo indireto, mais abstrato (ao menos nessa primeira fase dos contos), por meio do farfelu, 
do reino do fantástico, e tem como objetivo enfrentar o caos do mundo contemporâneo e assim possibilitar a busca de uma nova noção de homem, de novos valores que possam guiar e confortar o homem. A arte é crítica ao real, mas uma crítica que tem um objetivo sério, um fim além dela mesma, que é a construção de uma nova moral. Mesmo que a vitória da arte seja efêmera ou vã, ela deve ser um instrumento nessa busca que reflete a necessidade que o homem tem de encontrar um ponto sólido e seguro. Malraux descreve os problemas do mundo atual de forma séria e pensa que é necessário buscar seriamente uma saída ao caos da modernidade, e a arte seria essa instrumento que possibilitaria fugir da desordem por meio do fantástico ordenado. A arte visa, portanto, a um fim, a uma reconstrução de uma moral, da ordem - e nas aventuras dos personagens de Malraux podemos ver bem a busca da ordem esquecida, de uma nova noção de homem que possibilite reconstruir a civilização.

Nada mais distante das pretensões de Sartre. Embora este também conceba a arte como essencialmente crítica, e portanto ética, sua concepção de crítica se distingue radicalmente da de Malraux. A crítica para o filósofo francês não tem por objetivo a construção de algo ou a busca de novas noções e conceitos. A crítica que sua arte exerce é muito mais direta e ácida que a de Malraux e não poupa nem mesmo a si, seus personagens alter-egos. É de forma bruta que o narrador descreve seus personagens e o meio no qual eles vivem. $\mathrm{E}$ ao menos nesses contos não há nenhuma finalidade abstrata buscada por meio dessa crítica: Sartre pensa na crítica como aquilo que permite ao criticado se ver "atormentado pelo Mal" e a partir disso, ter de lidar conscientemente com a situação, sem desculpas. A arte é crítica porque desvela as ações humanas aos próprios homens, que a partir de então não podem fingir que ignoram seus atos; e é por esse desvelamento que a crítica deve ser exercida. A preocupação de Sartre é mais concreta e existencial que a de Malraux, já que não pretende buscar uma nova concepção metafísica do que seria o homem, mas justamente o contrário, mostrar o homem como aquele que inventa a cada ato e sem nunca cessar, uma arte, uma moral e a si próprio.

A ordem, uma nova noção de homem não são buscadas por Sartre. A crítica exercida por Malraux, na medida em que visa encontrar uma nova moral, seria também criticada por Sartre. A arte, para este, é crítica porque desvela o homem ao próprio homem e sua função deve se restringir a esse desvelamento, sem pretensões conceituais ou metafísicas, o que só diminuiria seu caráter crítico. 
Se por um lado Malraux e Sartre permitem e exigem que façamos a relação intrínseca entre estética e ética, já que a arte é crítica do mundo, a concepção distinta que têm de crítica nos permite entender como as atitudes que ambos exercem em seu tempo parecem às vezes tão semelhantes (quando envolvem questões mais gerais de crítica) e outras vezes tão opostas (quando estão em jogo questões de reconstrução positiva da ordem e dos conceitos).

Mas para compreender essa semelhança que às vezes se mostra como oposição é preciso ver agora suas obras de maturidade, nas quais ambos se voltam para importantes questões históricas. 


\title{
CAPÍTULO 2
}

\section{OS ROMANCES DE MALRAUX}

\author{
a) Os Conquistadores \\ b) A Via Real \\ c) A Condição Humana
}




\section{OS ROMANCES DE MALRAUX}

Após a análise dos contos de juventude de Malraux e Sartre, sempre com a perspectiva de mostrarmos a relação entre a estética e a ética, a maneira como cada autor revela uma concepção de arte que implica uma determinada concepção de ética, tentaremos agora compreender como se dá essa mesma relação em algumas das obras principais de ambos: Les Conquérants, La Voie Royale e La Condition humaine, no caso de Malraux, e Les Chemins de la liberté, no caso de Sartre.

Trata-se agora de analisar romances e não mais contos, o que dificulta e muito nossa pretensão. Temos agora narrativas maiores, o que nos impossibilita uma análise tão minuciosa dos textos, como a que tentamos fazer no capítulo anterior.

Antes, porém, uma questão se nos coloca: o que nos levou a escolher esses três livros de Malraux? Os livros de Sartre se justificam por serem uma trilogia, mas os de Malraux não apresentam nenhuma legitimação interna e desejada por ele. A escolha desses três livros se baseou em dois fatos: no cronológico e temático.

Os três livros de Malraux foram escritos um logo após o outro, e logo depois de sua viagem à Indochina: Les Conquérants em 1928, La Voie royale em 1930 e La Condition humaine em 1933. Temos então livros que são próximos uns aos outros, mas que principalmente se passam em um cenário parecido: O Oriente, a Indochina; e é esse o motivo principal pelo qual escolhemos analisá-los em conjunto, separando-os de outros textos que, embora também muito próximos cronologicamente, não o são em relação ao lugar em que a narrativa ocorre (caso, por exemplo, de Le Temps $d u$ Mépris, escrito em 1935 mas que se passa na Europa).

Esses três livros aqui escolhidos se passam no Oriente, na região ao redor da Indochina, o que já nos leva a fazer uma primeira distinção em relação aos contos de juventude vistos anteriormente: enquanto estes se passavam em regiões imaginárias e imprecisas (mesmo que bastante descritas), Les Conquérants, La Voie Royale e La Condition humaine se localizam em regiões precisas, exaustivamente descritas, e o mais importante: em regiões que são semelhantes às que realmente existem.

Malraux, após a viagem à Indochina, ao conhecimento da arte e pensamento oriental, volta à Europa e muda sua maneira de escrever. Se primeiro tínhamos contos farfelus, agora temos romances quase que jornalísticos. E nisso está a segunda grande 
diferença em relação aos contos anteriores: não só o lugar faz referência direta a um lugar real como os fatos narrados também o fazem. Não pretendemos dizer aqui que os livros de Malraux não são fictícios, mas que se os elementos dos contos de juventude eram declaradamente fantásticos, o mesmo não ocorre com esses romances $^{91}$.

Tanto Les Conquérants quanto La Condition humaine narram temas relacionados aos acontecimentos na China em 1925 e em 1927, e La Voie royale, embora não trate do mesmo assunto e tenha um ambiente um pouco mais fantástico e exótico que os outros, fala, em parte, de uma aventura vivida pelo autor: a busca de estátuas e baixo-relevos na selva cambojana.

Em relação ao cenário muda-se totalmente entre os contos de juventude e os romances, mas há também uma outra modificação bastante aguda: na maneira como os acontecimentos são narrados. Se nos contos os personagens não são humanos e o narrador é sempre objetivo, nos romances tudo é concreto, humano e o objetivo dá lugar ao subjetivo, aos pontos de vista, aos modos diferentes de se ver e agir. Nos contos a narração é direta, objetiva, sem lugar para as incertezas (que não as próprias do relato) e subjetividades; enquanto nos romances dominam as descrições fragmentadas sobre os personagens feitas sempre por vários outros personagens (ajudando a montar um quebra-cabeça que nunca se completa).

Não obstante todas essas diferenças entre os contos e os romances, há semelhanças grandes em relação a alguns temas essenciais. De modo ainda muito geral, podemos dizer que, embora de forma distinta, os temas que aparecem com grande importância nos contos - como o da aventura, do herói, da luta contra os valores, o destino e a morte, o papel da arte e da ação - reaparecem em Les Conquérants, La Voie Royale e La Condition Humaine e, acrescidos a novos temas (o da solidão x comunhão, indivíduo e comunidade, metafísica e história, ocidente e oriente) serão o cerne de todos os romances.

E se o modo como analisaremos os romances deve ser o mesmo como analisamos os contos - por meio de uma análise interna -, as diferenças acima apontadas entre eles nos trazem uma questão que antes estava ausente: a da relação, na própria narrativa, entre a ficção e a realidade. Antes, nos contos, partíamos de uma

\footnotetext{
${ }^{91}$ E não queremos dizer também que Malraux abandona de vez o farfelu (já que publica após Les Conquérants um conto farfelu, Royaume farfelu), mas apenas que sua forma predominante de narrar muda.
} 
análise interna do conteúdo e do modo narrativo para então compararmos com a concepção estética de Malraux, a qual revelava um certo papel das obras, uma certa ética. Mas agora esse método se torna mais complexo, pois os acontecimentos da vida de Malraux e da Revolução Chinesa penetram no fictício, misturam-se a ele, fazendo com que a relação entre a estética e a ética, por um lado, se torne mais clara e urgente, e por outro, mais complexa por colocar questões antes inexistentes, como a do papel do real na ficção (se inicialmente isso torna mais fácil a análise, pois o próprio conteúdo fictício é real, mostra atitudes humanas que implicam necessariamente uma maneira de ver a ética, logo percebe-se que, por se tratar de uma obra fíctícia, não se deve fazer essa relação direta entre o real narrado e o real vivido - o que nos levará a problematizar essa ligação).

Devemos ter sempre em mente duas questões que esses três romances (e também os de Sartre, que serão vistos no próximo capítulo), por narrarem acontecimentos reais, trazem:

a) Por um lado, o real imerso no imaginário mostra a nova preocupação de Malraux por tratar de problemas vividos por ele, e de forma mais direta, ao contrário da forma totalmente alegórica adotada por ele nos contos. E se agora a preocupação principal é com os fatos e não mais com um imaginário fantástico e farfelu, podemos então dizer que a ética deixa de ser um cenário decorativo aos fundos (e que para alcançá-lo seria necessário passar pelo tema central) para ser a própria encenação da peça, o tema do quadro.

E se "como escreve Lukács, o romance é o único gênero literário em que a ética do romancista converte-se em problema estético da obra"92 por ser o romance uma história de uma investigação degradada, a busca do indivíduo por valores autênticos em um mundo que também está degradado, trazendo sempre consigo a problematização dos valores, da moral; podemos especificar essa definição dizendo que ela é ainda mais válida quando o romance é narração fictícia do real, o que, principalmente no século XX, é muito frequënte $e^{93}$.

Se todo romance pode ser visto como a conversão de uma ética em problema estético, o romance histórico o é ainda mais. A questão ética do romancista é colocada aqui sob holofote: o que se visa no romance é justamente a problematização dos

\footnotetext{
92 GOLDMANN. Sociologia do Romance - p. 14.

${ }^{93}$ Só para citar alguns nomes: Sartre, Malraux, Primo Levi, Naipaul.
} 
valores sociais e morais, as atitudes frente a acontecimentos tão complexos que torna desaconselhável uma simplificação ética da disputa entre o bem e o mal.

A ética é então a própria questão dos romances que serão analisados; ela deixa os bastidores para se tornar personagem principal. E se com isso nosso objetivo de mostrar a relação entre estética e ética se torna muito mais fácil à primeira vista, já que a ética fica muito mais visível, esse mesmo fato nos traz uma problemática que deve ser considerada.

b) Embora a ética esteja sempre presente em Les Conquérants, La Voie Royale e La Condition humaine, ela o é justamente de uma forma fictícia, imaginária. Mesmo que o real prepondere sobre o imaginário, não se trata propriamente do real vivido: temos aqui obras de fícção, e o real, por mais verificável que seja com o que realmente aconteceu, é fictício, imaginado.

É preciso distinguir o real vivido do real narrado de uma certa maneira, com intenções próprias, ordenado de modo a indicar (mas nunca determinar) um certo significado. Mesmo que Malraux tratasse da Revolução Chinesa do exato modo como ela foi feita, não teríamos um relato exclusivamente jornalístico, "verdadeiro": trata-se de romances sobre aventuras na China e arredores, e como romances, não pretendem ser representações da "Verdade". O romance pertence ao domínio da arte, do imaginário, mesmo quando o imaginário é ordenado com dados dos acontecimentos reais.

E se é assim, não podemos passar diretamente da ética narrada para a ética vivida: entre a Revolução Chinesa descrita nos livros e a Revolução Chinesa feita a partir de 1925 há vários intermediários que não podem ser considerados simples espelhos. Entre o mesmo acontecimento vivido e o narrado de forma fictícia existe a obra e o autor (e o leitor, que embora seja essencial, não será analisado aqui). É o autor quem transforma o vivido em narrado por meio de sua obra, e nessa escrita temos necessariamente uma transformação, que se dá não malgrado o próprio autor mas por seu expresso desejo ${ }^{94}$.

Como diz Antônio Cândido, a crítica literária deve "ter consciência da relação arbitrária e deformante que o trabalho artístico estabelece com a realidade"155. E é justamente o aspecto deformante que o autor e a obra estabelecem com o real que

\footnotetext{
${ }^{94}$ Penso que poucos escritores escrevem romances com a pretensão de ser totalmente fiel ao real - e mesmo esses sabem que só é possível alcançar a fidelidade graças à traição.

${ }^{95}$ CÂNDIDO, A. Literatura e Sociedade - p. 12.
} 
torna simplista a ligação direta entre a ética narrada e a ética vivida. Entre uma e outra há uma intenção estética do artista que se concretiza na forma de uma obra (no caso, o romance), a qual deve ser levada em consideração. A estética do autor deforma o real e sua ética para criar um outro real e uma outra ética, e é na deformação realizada pelo autor e na comunicação estabelecida pela obra que devemos procurar como se dá a relação entre a concepção estética (revelada justamente por meio da deformação) e a concepção ética (entrevista pela comunicação) do autor, no caso, de Malraux.

A questão sobre o estatuto do real no imaginário, de como considerar o fato em sua relação com o fictício, principalmente quando este narra acontecimentos próximos aos reais, é por demais complexa e delicada para ser por nós discutida aqui. É um problema com o qual, no entanto, teremos de nos deparar ao analisar os romances - e se a teoria e prática de Antônio Cândido (a de que o externo "importa, não como causa, nem como significado, mas como elemento que desempenha um certo papel na constituição da estrutura, tornando-se, portanto, interno") ${ }^{96}$ nos parece ideal e por isso mesmo impossível de ser por mim realizada, ao menos tentaremos não cair no erro e simplificação descritos acima: no de que o narrado é representação fiel ao vivido e de que portanto é possível correlacioná-los diretamente, dizer que as atitudes descritas nos romances são as atitudes aprovadas e prescritas pelo autor, constituindo, sem intermediários, um código de ética a partir de um conteúdo moral fictício.

E será precisamente com essas constatações de que a ética é personagem principal dos romances de Malraux e de que isso, ao invés de facilitar nosso trabalho, o tornará mais complexo (já que devemos evitar o erro de deduzir um código de ética prescrito diretamente a partir de uma ética narrada de modo fictício), que faremos nossa análise.

\section{A) Les Conquérants}

Livro escrito logo após a segunda viagem de Malraux para a Indochina, mostra-se à primeira vista bem distinto dos contos. Embora pouco tempo separe esse romance de Écrit pour une idole à trompe, as diferenças são notáveis: enquanto no

\footnotetext{
${ }^{96}$ IBIDEM - p. 4.
} 
conto ainda predomina o farfelu, em Les Conquérants há uma "queda" brusca no real e em seus problemas.

Após alguns meses na Indochina dirigindo jornal contra os abusos da colonização francesa e propondo uma cooperação franco-anamita, Malraux decide voltar à França (os motivos reais de sua volta, assim como os da ida, são muito discutidos) e lá, já célebre pela aventura que realizara, publica Les Conquérants em 1928 .

E se é certo que os acontecimentos reais ganham importância nesse livro de Malraux, é certo também que, diferente do que Sartre fará na década de 40, mostrando na ficção os próprios franceses na França nas vésperas da Segunda Guerra Mundial, Malraux escolhe falar do Oriente, de Cantão e da revolta que os comunistas, junto com Tchang Kaï-chek, preparam para vencer os colonizadores e senhores do norte.

Quanto aos temas históricos, o romance traz uma questão que foi a mais discutida pelos intelectuais franceses da época: a do comunismo e o papel da III Internacional. Toda a Revolução é guiada e liderada por dois homens: Garine (o "conquistador" solitário europeu) e Borodine (o russo e sua "fábrica de comunismo"), sendo impossível não suscitar reações e questões a respeito da relação da França com a URSS, ainda mais na década da fundação e fortalecimento do Partido Comunista Francês (PCF).

Podemos dizer então que boa parte da crítica a Les Conquérants voltou-se para a maneira como o autor narrou a relação do comunismo (URSS) com a Revolução Chinesa, fazendo com que viesse à tona uma discussão histórica com a qual a França se deparava na época. Estaríamos então diante de um romance que, além de ser histórico no sentido de relatar um acontecimento que faz referência direta a um acontecimento real, é também histórico porque não se poderia lê-lo sem problematizar uma questão urgente para os intelectuais e a esquerda francesa (a relação do PCF com a URSS)?

Mas é o próprio Malraux quem diz, em uma carta a Trotsky, que comentara o romance, que "Ce livre n'est pas une 'cronique romancée' de la révolution chinoise, parce que l'accent principal est mis sur le rapport entre des individus et une action collective, non sur l'action collective seule" ${ }^{97}$. O próprio autor diz que o tema principal

\footnotetext{
${ }^{97}$ MALRAUX. Oeuvres Complètes - p. 309.
} 
de seu livro não é a ação coletiva considerada sozinha, mas a relação entre os indivíduos e a ação coletiva, no caso, a Revolução Chinesa.

E a maneira como Malraux constrói, ao longo do romance, a relação de Garine com a Revolução Chinesa (que reflete a relação do indivíduo com a história) nos leva a minimizar a importância desta para dar prioridade à questão do indivíduo, da solidão que ele enfrenta diante da morte, o destino certo.

Garine, conforme nos é apresentado pelo narrador e outros personagens do romance, é um aventureiro solitário, um europeu que deseja desafiar os valores burgueses e tentar, na luta contra o destino, dar um sentido à vida. E embora seja um dos dois principais líderes da insurreição em Cantão, não se sente ligado de modo nenhum à Revolução que defende ${ }^{98}$. A revolta de Garine é mais metafísica que histórica, e a História, nessa circunstância, perde sua importância, não se difere muito de um cenário no qual se desenrola sempre a mesma (essa sim importante) luta contra a morte e o destino.

Assim, se a presença da história, do real, é a primeira principal característica do romance frente aos contos de juventude, trata-se de uma história que se torna cenário e não tema, enfraquecendo, desse modo, sua principal questão. Podemos dizer que Les Conquérants é um romance histórico que enfraquece a História em prol da Metafísica.

O romance é composto por três partes e a primeira, "Les Approches", já nos indica que não teremos o relato da ação principal, mas sim uma aproximação aos personagens e às suas ações. Os personagens principais não aparecem em cena mas são constantemente citados e desse modo preenchem com suas ausências a primeira parte. Embora não "compareçam", essa primeira parte só existe para que eles se tornem para nós, leitores, familiares - e para que suas primeiras aparições já sejam carregadas de significados por nós construídos ao longo da primeira parte (à diferença de La Condition humaine, na qual os personagens aparecem sem que nada saibamos deles).

\footnotetext{
${ }^{98}$ Malraux não concorda com essa visão individualista de seu herói, dizendo em um debate em $1929 \mathrm{em}$ Paris que Garine coloca sua vida em jogo pela causa, o que só é possível para alguém que se sente ligado, de alguma forma, à Revolução - mas tentaremos tratar essa questão com detalhe depois.
} 
Essa apresentação não é feita, porém, por um narrador onisciente, que já soubesse tudo dos personagens que irá narrar. Mesmo que haja uma "preparação" para a entrada dos personagens principais, ela não é feita de modo convencional: é por meio de um narrador "misterioso" (do qual nada sabemos no início e que passamos a saber muito pouco no final) e de vários relatos feitos por vários personagens secundários que os personagens principais começam a aparecer. $\mathrm{O}$ narrador em primeira pessoa "recolhe" em sua viagem informações sobre os acontecimentos do lugar ao qual está indo e sobre os personagens com quem irá se encontrar, e é só aos poucos que conhecemos os personagens principais, Garine, Borodine, Hong e Tcheng-daï.

Mas em nenhum momento estamos diante de uma descrição objetiva e absoluta dos acontecimentos e dos personagens: o narrador parece saber tanto quanto o leitor sobre o que encontrará na "página seguinte" e ficam claras a subjetividade e parcialidade dos relatos feitos pelos personagens secundários. Fugindo da objetividade ilusória, Malraux escolhe narrar pela técnica do ponto de vista: "La meilleure manière de fuir cette illusoire objectivité, le romancier l'a trouvée dans la technique du point de vue, qui lui fournit la limitation idéale. Ce que nous lisons, nous ne le tenons pas d'un narrateur omniscient, invisible et toujours présent, mais des yeux, de la conscience de tel ou tel personnage impliqué dans l'action"99.

Ao mesmo tempo, porém, em que os personagens principais aparecem e são construídos por meio dos relatos subjetivos e sempre incompletos do narrador e de outros personagens, temos o recurso a uma outra técnica, que é a de precisar, por meio de datas e frases curtas, o decorrer dos acontecimentos.

A primeira parte pode ser divididas em "capítulos" cujos nomes são datas (25/06, 01/07 e assim por diante) e o lugar em que o que será narrado acontece. Como ainda estamos na primeira parte do livro, na viagem que o narrador (sem nome) faz de navio até Cantão, temos várias paradas em cidades diferentes (Saigon e Hongkong) e as datas se referem ao que acontece nelas e qual a situação geral do acontecimento maior que está sendo arquitetado - a Revolução Chinesa. Temos, portanto, uma determinação temporal e espacial precisa, o que nos faz aproximar Malraux da técnica jornalística, sem, no entanto, identificá-lo com ela.

\footnotetext{
${ }^{99}$ MALRAUX. Oeuvres Complètes - p. 987.
} 
Se é certo que Malraux trata de acontecimentos reais em seu romance e até mesmo de alguns personagens reais (como Tchang Kaï-chek), e o faz por meio de datas e lugares verificáveis, de documentos reais, utilizando às vezes notas de rodapé para explicar os termos - tudo o que o aproximaria de um jornalista e/ou historiador na busca da verdade (e o que faz Maria Teresa de Freitas, de modo preciso e rigoroso, chamar esses elementos de "procedimentos de autentificação da narrativa"); é certo também que se trata de ficção, e como tal, traz personagens imaginados, cenários e episódios imaginários. Mesmo que haja procedimentos para tornar a narrativa histórica e verificável, ambos (narrativa e procedimento) são tornados fíctícios (a ficção contamina a História, como diz ainda Maria Teresa de Freitas).

O discurso utilizado por Malraux na primeira parte de Les Conquérants é portanto híbrido: engloba as informações objetivas das datas e lugares e ao mesmo tempo multiplica as visões e relatos sobre os personagens principais (todos eles imaginários), dando lugar, assim, às dúvidas e à subjetividade.

É assim que vemos o início do romance: em primeiro lugar, a data (25/06) e a informação de que a greve geral foi decretada em Cantão. Em um navio indo para não se sabe onde, o narrador descreve seus companheiros de viagem mas nada conversa com eles; é um solitário que também se mostra interessado nos acontecimentos da China e que se sente angustiado, conforme podemos ver por suas descrições e palavras: "Le ciel plein de nuages fait peser sur nous une atmosphère de cabine de bains, nous entoure d'air saturé" ${ }^{100}$.

Uma greve geral em Cantão e em Hong Kong ameaça os comércios internacionais e com isso, o poder dos europeus na China (e é para essa ameaça econômica que o narrador chama a atenção, dizendo que é isso que mais preocupa os passageiros do navio). E ao descrever a situação que ele vê em relação aos outros personagens (sem nunca falar de si) e aos acontecimentos, o pesado silêncio é rompido por "un grand mouvement sur le pont" ${ }^{101}$ : novas notícias chegam e todos se amontoam para vê-las, e o que descobrem sobre Cantão é que os cadetes da escola militar de Whampoa (comandada por oficias russos e por Tchang Kaï-chek) atacam a

\footnotetext{
${ }^{100}$ MALRAUX. "Les Conquérants" In Oeuvres Complètes - p. 117, grifos nossos.

${ }^{101}$ IBIDEM - p. 118.
} 
concessão européia de Cantão (Chamien), mostrando assim que a China do Sul não era mais segura para os europeus ${ }^{102}$.

Dias depois, o narrador encontra-se em Saigon e no caminho à casa do presidente do Kuomintang da Conchinchina, descreve a cidade como desolada e deserta. Se os comentários que o narrador fazia no navio eram referentes a burgueses e/ou comerciantes com medo de perderem seus negócios em HongKong, agora começamos a adivinhar que ele faz parte do lado oposto, dos que fecham o comércio e fazem a greve: nosso narrador fala em cantonês (o que já mostra um conhecimento anterior do país) com o presidente do Kuomintang, partido fundado por Sun Yat-sen e aliado ao PC chinês.

E enquanto espera o presidente do Kuomintang da Conchinchina, o narrador assim observa a sala na qual está: "une armoire européenne, une table Louis-Philippe à dessus de marbre, un canapé chinois en bois noir et de magnifiques fauteuils américains, tout hérissés de manettes et de vis. Dans la glace, au-dessus de moi, un grand portrait de Sun Yat-sen, et une photographie, plus petite, du maître de céans" ${ }^{103}$, tudo isso sob o som de um "marchand de soupe" e o odor das "graisses chinoises qui cuisent...".

Estamos portanto diante de um ambiente chinês no qual quase nada é chinês: com móveis europeus e americanos misturados a móveis e retratos, odores e sons chineses. E será justamente essa relação entre europeus e chineses, mostrando uma Revolução Chinesa feita e dirigida por europeus, que o narrador enfatizará em quase todo o livro através dos sentimentos europeus que devem ser introduzidos para que os chineses possam pensar em uma revolução.

Essa impressão também é confirmada pelas palavras do francês Gérard, o presidente do Kuomintang da Conchinchina, que chega e informa inicialmente ao narrador sobre a situação da greve, da interdição dos navios aportarem em HongKong - e da grande quantia que os trabalhadores deram ao Partido (6 mil dólares, que serão dados ao narrador para o restante da viagem), o que demonstra o entusiasmo dos chineses por terem conseguido imobilizar a Inglaterra. Mas toda essa descrição

\footnotetext{
${ }^{102} \mathrm{O}$ tempo todo passamos das informações pretensamente objetivas dos fatos (dadas pelas notícias, data, local) para o olhar assumidamente subjetivo do narrador (e deste para aquela) - esse movimento permanecerá constante em todo o livro.

${ }^{103}$ MALRAUX, op. cit. - p. 120.
} 
otimista sobre a greve finda com essa frase: "Mais c'est bien peu chinois tout cela..." ${ }^{104}$.

Mas o narrador se mostra menos interessado no espírito europeu da Revolução que na aparição do nome de Garine, nosso personagem principal que aparecerá apenas na segunda parte do livro. Gérard, no entanto, descreve Garine sob as mesmas perspectivas: o modo como ele e Borodine tentam entranhar sentimentos estranhos aos chineses. A Revolução Chinesa é pouco chinesa não apenas porque tem como presidente do Kuomintang da Conchinchina um francês, não apenas porque as salas são mobiliadas por móveis europeus e americanos, mas também e principalmente porque ela só se mostra possível com sentimentos tipicamente não chineses - e segundo Gérard, tanto Borodine quanto Garine tentam introduzir, com diferenças marcantes, sentimentos como a ação.

E a diferença no modo como os dois líderes, Borodine e Garine, dirigem a propaganda é fundamental para já delinear a função que ambos exercerão no decorrer da ação e do livro. Enquanto o primeiro, para Gérard, enfatiza o fato deles serem trabalhadores e pertencerem a uma grande força do Estado (o que, segundo Gérard, não dá certo); o segundo (Garine) faz uma propaganda nacionalista e violenta, "en leur donnant la possibilité de croire à leur propre dignité, à leur importance si vous

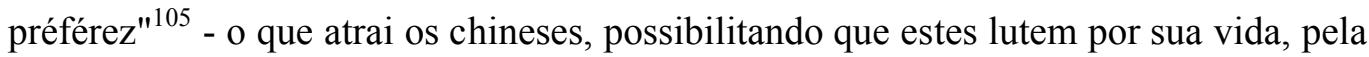
dignidade, pela individualidade que Garine fez nascer neles.

E diante de perguntas feitas pelo narrador, Gérard continua o retrato dos dois grandes líderes da Revolução, sempre comparando-os e contrastando-os. Se Borodine é um homem de ação, Garine é um homem capaz de ação. E se Borodine é um revolucionário profissional, corajoso, bolchevique, para quem a China é uma matériaprima, Garine é um aventureiro que chegou em Cantão ainda na época de Sun Yat-sen (em torno de 1921, 22) para "jouer leur vie"106, que está mais ou menos ligado à China e faz parte das pessoas que "n'ont jamais pu accepter la vie sociale, qui ont beaucoup demandé à l'existence, qui auraient voulu donner un sens à leur vie, et qui maintenant, revenus de tout cela, servent" ${ }^{107}$.

\footnotetext{
${ }^{104}$ IBIDEM - p. 121.

${ }^{105}$ IBIDEM - p. 123.

${ }^{106}$ IBIDEM - p. 124.

${ }^{107}$ IBIDEM - p. 124.
} 
Temos então, a primeira aparição de dois dos principais personagens. $\mathrm{O}$ narrador, mostrando não conhecer nenhum dos dois (ao menos não conhecê-los bem, já que pelo nome sabe quem são), pergunta ao francês Gérard quem são eles, o que fazem, como fazem e qual a relação entre os dois. E Gérard traça um retrato bastante interessante de ambos: Borodine é um bolchevique profissional que vem à China para trabalhar na Revolução, enquanto Garine é um aventureiro que serve à Revolução para tentar encontrar um sentido em sua vida.

No jantar no restaurante do presidente da seção de Cho Lon, lugar no qual nada mais é francês, os chineses dão a impressão de que "la seule force de ce gens est un sentiment trouble, que les maux qu'ils ont subis sont la seule chose dont ils aient vraiment conscience" ${ }^{108}$, e só falam das notícias positivas da guerra (o envio de armamentos pela Rússia, atentados terroristas etc); mas Gérard sai do mesmo jantar preocupado, pois seu vizinho de mesa lhe comunicara que Tcheng-daï, sem nenhuma dúvida, se oporá abertamente a eles. E diante do narrador que não entende a importância dessa notícia, Gérard explica a ele que Tcheng-daï é o homem mais influente de Cantão e o chefe espiritual de toda a direita do partido do Kuomintang, que o chama de o Gandhi chinês.

$\mathrm{E}$ ao contar das ameaças constantes à greve, dos complôs militares, o terrorista Hong aparece no diálogo. Gérard inicia sua descrição de Hong, em quem Garine tem muita confiança (a ponto de fazer dele seu secretário) e que tem a febre da juventude, dizendo que ele não é um chinês comum. O francês o define como "uma criança", como um homem que saiu da miséria e que foi criado por um homem que vende curiós e souvenires em uma loja - e propõe então ao narrador ir à casa desse senhor no dia seguinte para conhecer um homem que formou terroristas e para beber um pernod verdadeiro.

Mais dois importantes personagens aparecem nesse dia em Saigon por meio do diálogo com Gérard: ser por um lado, Garine e Borodine aparecem juntos como dois líderes estrangeiros da Revolução, ambos agindo ou capazes de ação, por outro lado, Tcheng-daï e Hong (ambos chineses) aparecem como semelhantes no extremo que apresentam: se Tcheng-daï é descrito como líder da direita do Kuomintang e como

${ }^{108}$ IBIDEM - p. 126. 
veremos depois, extremista em seu pacifismo, Hong se apresenta extremista na ação, no terrorismo ${ }^{109}$.

Junto com Gérard, o narrador visita Rebecci, genovês que tem loja em Saigon e contava histórias para jovens, dentre os quais Hong (o terrorista), por quem Rebecci nutriu uma grande simpatia. É Gérard quem conta essa história ao narrador antes da visita; é por ele que ficamos sabemos que Rebecci foi tocado por Hong adolescente em quem ele via uma certa ingenuidade, mas também uma rara coragem acrescentada por um fanatismo.

Rebecci, antigo anarquista militar que preferia esquecer essa parte de sua vida, assim ensinava Hong: "Quand on a ouné vie seulement, on ne cherche pas à changer l'état social... Cé qué difficile, c'est dé savoir cé qué l'on veut. Voilà: qué si tu fous une bombe dessus le magistrat, comprends-tu, il en crève, et c'est biein. Mais qué si tu fais un journal pour qué la doctrine elle soit connue, tout le monde il s'en fout..."110.

O ensinamento de Rebecci a Hong é a completa submissão da letra à ação: mais eficaz é explodir uma bomba que escrever as justificativas. É a ação que importa (ao menos aos outros) e não as questões teóricas que estão por trás dela - e é desse modo que Hong agirá no decorrer do livro, enfrentando Garine e Borodine por estes apresentarem razões e justificações quando era o ato que importava e se mostrava urgente. Hong em nenhum momento fará concessões às estratégias adotadas pelos dois líderes, mostrando assim que aprendeu bem a lição de Rebecci de que ninguém se importa com a doutrina e sim com a bomba (e que se há apenas uma vida, é preciso vivê-la bem, agir). Mesmo que Rebecci fale isso com rancor, lamentado o fato de ser assim, é essa a lição que passa a Hong.

Já na casa de Rebecci, Gérard pede que este fale diretamente de seu relacionamento com Hong. O pedido, no entanto, não é bem aceito: se Rebecci se mostra silencioso e solícito no início da conversa, assim que Gérard pede a ele que fale de Hong, ele se transforma, e entre nervoso, irritado e preocupado, diz que naquele dia ele não falaria, já que soubera de manhã que Hong fora preso pelos ingleses (e pede que Gérard se informe sobre isso).

\footnotetext{
${ }^{109}$ É interessante notar que se Garine e Borodine, estrangeiros, surgem durante o dia, com a descrição da cidade como ensolarada e desolada, com muito calor e em ruas vazias, Tchen-daï e Hong, chineses, surgem à noite, durante as andanças após o jantar, com luzes, barulhos, gritos, com chineses pobres andando pelas ruas em meio aos carros. Malraux mostra, assim, por meio de seu narrador, uma caracterização da Europa como sendo claridade e a China como escuridão e confusão...

${ }^{110}$ MALRAUX. "Les Conquérants" In Oeuvres Complètes - p. 133.
} 
É com sua negação que o dia 01/07 acaba e com ele, a estadia do narrador em Saigon. No dia 02/07 ele se encontra novamente no navio em direção a Hongkong, e descreve o sentimento de todos como se fosse o mesmo: um estado confuso no qual se mistura o torpor e a regularidade do navio, e a consciência de que Hongkong se torna cada vez menos um nome e cada vez mais real: "Heure par heure (...) HongKong devient plus réelle, cesse d'être un nom, un lieu quelque part en mer, un décor de pierre; chacun sent la vie la pénétrer"111.

No barco indo a Hongkong é a inquietude que domina, a sensação de estar cada vez mais próximo e menos livre (a realidade impede a liberdade, essa só é possível abstratamente?) - "un état trouble, dans lequel se mêlent l'énervante régularité de la marche du navire et la conscience, pour chacun, d'éprouver ses derniers instants de liberté: les corps ne sont pas encore engagés, l'inquiétude n'a qu'un objet abstrait (...). Ne pas voir encore, connaître seulement les nouvelles, n'être pas encore envahi"112. Estar engajado é, para o narrador, não ser livre - a liberdade parece ser apenas um atributo abstrato, um nome, do lado da teoria e não da ação.

E é na Hongkong real, com a greve geral já decretada, assim como o estado de sítio, que o navio embarca no dia 05/07 às 9 horas da noite. E ainda no navio o narrador descreve as luzes serradas, o ar morno e tão calmo da cidade, na qual eles só poderão entrar na manhã seguinte (sem que ninguém no entanto, consiga dormir).

Devido à greve, nenhum coolie (mão-de-obra barata, normalmente fazendo trabalhos pesados nos portos) aparece para carregar as malas e os passageiros são obrigados a carregar suas malas nessa cidade que se antes abrigava toda a atividade da ilha, hoje encontrava-se deserta e silenciosa - sem automóveis, sem mulheres brancas. Em meio ao desértico calor da cidade, o narrador fala com o sub-delegado do Kuomintang, o também francês Meunier (que deve entregar documentos para o narrador prosseguir sua viagem até Cantão) e com o organizador europeu da greve, o alemão Klein.

O diálogo entre Meunier e o narrador se dá nos mesmos termos do de Gérard: o francês explica os acontecimentos e informa ao narrador sobre alguns líderes, como Hong, Borodine e Garine. Mas agora as definições são bem mais objetivas e curtas: Hong não fora preso, estava seguro em Cantão (era a propaganda inglesa que espalhou a notícia errada), Borodine tem muita experiência mas ama demais os russos. Garine

\footnotetext{
${ }^{111}$ IBIDEM - p. 136.

${ }^{112}$ IBIDEM - pp. 136 - 137.
} 
conseguiu transformar os grevistas de Cantão em agentes ativos de propaganda mas começa a ter doenças tropicias.

Novamente temos a idéia já dita explicitamente por Gérard de que a greve é pouco chinesa: tanto Borodine quanto Garine (este com mais eficiência, segundo os franceses), na propaganda e nas armas, entranham sentimentos "não-chineses" como a dignidade, a individuação, a coragem e principalmente a ação (embora o que se veja são greves - que o narrador chama de passividade hostil). E se os líderes europeus e russos buscam a ação e a vitória, o líder chinês, Tcheng-daï, começa a se mostrar contrário à ação, ao ataque, o que é muito perigoso, já que é bastante influente, é um mito, assim como Gandhi (e para Meunier "il ne faut pas chercher de gens comme ça en Europe...") ${ }^{113}$.

Se os líderes não chineses buscam a ação, são heróis, o líder chinês busca a paz, é um mito. E é entre esses dois pólos que o governo de Cantão tenta se manter, oscilando entre um e outro sem se decidir, no entanto, por nenhum dos lados - o que não será mais possível se Garine conseguir o que deseja: promulgar um decreto no qual os navios não poderiam mais fazer escala em Hongkong (fazendo com que o porto deixe de funcionar).

É então que Klein chega, e cansado, relata todos os maiores problemas da greve: justamente por seu sucesso em Cantão (onde a greve já dura há 15 dias) e pelo início em Hongkong, é necessário muito dinheiro para pagar os grevistas (Garine e Borodine fizeram um fundo de greve através do aumento dos impostos, mas isso já não se mostrava mais suficiente). $\mathrm{E}$ as medidas que precisavam tomar para a continuação da greve e da Revolução são recusadas pelo Comitê soberano, e isso devido à influência de Tcheng-daï. E enquanto a esquerda e a direita do Kuomintang começam a divergirem entre si, um general começa a criar uma tropa (com a ajuda da Inglaterra) para conquistar Cantão.

Se de um mesmo lado temos 3 divisões: Garine e Borodine (ainda juntos) e a tentativa de estratégias, Hong e a violência extremada, Tcheng-daï e o pacifismo extremo; do outro lado todos se unem (generais, senhores do norte e ingleses) para acabar com o poder principalmente dos dois primeiros grupos, já que Tcheng-daï, pacífico, não oferecia problemas, e influente, melhor era não atacá-lo.

${ }^{113}$ IBIDEM - p. 143. 
A Revolução Chinesa, assim como Hongkong aparecia no navio para o narrador, vai tornando-se a cada dia mais concreta e complexa. Pelas descrições dos franceses Gérard e Meunier e do alemão Klein, vamos formando os enredos e personagens aos quais teremos acesso diretamente apenas na segunda parte.

É com toda essa nova carga de informações que o narrador parte novamente (e definitivamente) para seu destino final, Cantão, junto com Klein. À noite, decide arrumar e ler os papéis que se encontravam em seus bolsos, entre eles antigas cartas de Garine. Sua atenção volta-se para um documento que Meunier lhe dera: fichas da Segurança de Hongkong sobre Garine - e por um instante todos os outros documentos saídos de seu bolso perdem a importância; mas é só por um breve momento: logo a seguir ele revela, falando consigo mesmo, que fora amigo por muitos anos de Pierre Garine e que não o via há 5 anos, desde a despedida em Marselha.

O narrador se mostra, aqui, de modo muito diverso de como o víamos no início do livro. Se ele parecia saber tanto quanto o leitor e durante sua viagem, através das conversas com Gérard, Meunier e Klein, formava uma melhor idéia de quem era Garine e outros personagens, vemos agora que ele conhece muito bem Garine e talvez melhor que os outros três personagens que falaram sobre ele. Mais que coletar dados, sua posição foi a de um juiz silencioso, que ouve pessoas falarem de um antigo amigo e que nada revela sobre ele.

E agora, a cada informação que lê no relatório da Segurança de Hongkong, o narrador emite um parecer, corrigindo as informações incorretas, como o ano de seu nascimento e principalmente suas ações anteriores.

Enquanto o relatório afirma que Garine era anarquista militante, o narrador desmente, revelando que

en 1914 - à vingt-ans - encore sous l'influence des études de lettres qu'il venait de terminer et dont il ne restait en lui que la révélation de grandes existences opposées ('Quels livres valent d'être écrits, hors les Mémoires?') il était indifférent aux systèmes, décidé à choisir celui que les circonstances lui imposerait. Ce qu'il cherchait parmi les anarchistes et les socialistes extrémistes, malgré le grand nombre d'indicateurs de police qu'il savait rencontrer chez les premiers, c'était l'espoir d'un temps de troubles ${ }^{114}$.

${ }^{114}$ IBIDEM - p. 150. 
Agora é o próprio narrador que descreve Garine e sua figura se transforma: o grande líder da greve em Cantão, capaz de transformar chineses em soldados, de dar a eles o sentido e a necessidade de serem vistos como indivíduos, de terem dignidade e coragem, não parece ser realmente ligado às idéias que baseiam sua ação: estudante que concluira que apenas as Memórias valem ser escritas (revelando assim, o gosto pelas grandes ações e pelos heróis), é indiferente aos sistemas e conviveu com os anarquistas e socialistas extremados apenas porque esperava, junto deles, alcançar tempos problemáticos, agitados.

Em sua juventude ligada aos socialistas, não buscava uma Revolução, a solução de problemas, mas justamente o contrário, a confusão. Ambicioso, Garine pensava que a conquista é que mantém a alma do chefe (novamente, a alma é sustentada, mantida pela conquista - é a ação, e não o pensamento, que faz do chefe um chefe); e como desejava ser um chefe, age, mais por vanidade e indiferença que por conviç̧ão: rico, doa dinheiro para que mulheres abortem "pela causa anarquista" e por isso é julgado.

E se no início era também indiferente ao julgamento, a possibilidade de ser condenado levou Garine a se defender, já que, segundo o narrador, "jouer sa vie sur cette carte sale, ridicule, qu'il n'avait pas choisie, lui était intolérable" ${ }^{115}$. Como Garine diz em um telegrama ao narrador nessa época, a sociedade não era má (e portanto não era suscetível de ser melhorada), mas sim absurda, e comenta de sua impossibilidade de dar a qualquer forma social sua adesão.

Homem que se envolve na luta anarquista dando dinheiro para mulheres abortarem sem se ligar, no entanto, ao movimento; homem que é condenado a seis meses de prisão mas com sursis; homem que se engaja em 1914 na legião estrangeira esperando combates mas sem se interessar pela origem dos conflitos e que deserta em 1915 por ver que no lugar do combate encontrou a imobilidade... Garine se mostra desde a juventude com sede de ação, mas como ele mesmo reconhece, sem nunca aderir a nenhuma forma social. Teria mudado esse homem que hoje comanda a Propaganda em Saigon? Ele teria aderido à Revolução Chinesa ou continuaria indiferente à causa que justifica suas ações?

Após a fuga da guerra (que se passou como desaparecimento), Garine se instala na Suiça e conhece jovens bolcheviques, de quem fica amigo mas a quem

${ }^{115}$ IBIDEM - p. 152. 
reprovava o dogmatismo: "si la technique et le goût de l'insurrection chez les bolcheviks le séduisaient, le vocabulaire doctrinal, et, surtout, le dogmatisme qui les chargeaient l'exaspéraient"116 ${ }^{116}$ E novamente nos fica uma questão que só poderá ser respondida nas próximas partes: qual será a relação de Garine com Borodine, bolchevique vindo da Rússia para organizar a Revolução? O jovem Pierre teria mudado, reconhecido o valor de um certo dogmatismo ou continuaria indiferente a isso, desprezando e não aderindo a nenhuma forma social?

E mais uma mentira aparece no relatório da Segurança de Hongkong: a de que Garine fora enviado a Cantão, em 1918, pela Internacional. O narrador nos conta que um amigo de infância (Lambert, nascido também em Haiphong - e como era costume na cidade, criado por uma babá de Cantão - assim como o narrador, o que explicava porque este sabia o dialeto cantonês) partiu para a China em 1914 e, colaborador de Sun Yat-sen, enviou carta a Garine, propondo que ele fosse para lá para ganhar US\$ 800 por mês.

Garine vai a Cantão para sair da Europa e para ganhar dinheiro - suas causas são práticas e concretas, nunca teóricas e ideológicas. Aceitando o convite de Lambert, vai com o narrador até Marselha, de onde pegaria o navio até Cantão. $\mathrm{O}$ narrador nos conta que a impaciência dominava Pierre em Marselha, e que na despedida este confessara ao narrador que não amava os homens, nem mesmo os pobres, o povo por quem ia combater em Cantão; que só os preferia porque eram vencidos. "Oui, ils ont, dans l'ensemble, plus de coeur, plus d'humanité que les autres; vertus de vaincus... Ce qui est bien certain, c'est que je n'ai qu'un dégoût haineux pour la bourgeoisie dont je sors. Mais quant aux autres, je sais si bien qu'ils deviendraient abjects, dès que nous aurions triomphé ensemble..." ${ }^{117}$.

Portanto não, Garine não mudara. Mesmo líder da greve em Cantão, ele não aderia à Revolução Chinesa: só estava ali porque tinha ódio dos burgueses e enquanto os vencidos continuassem vencidos. O que desejava era combater a burguesia da qual saíra e a qual detestava. E é apenas esse momento de combate que lhe interessava: a vitória não lhe importava, ou melhor, não era nem mesmo desejada, já que os vencidos, tornando-se vencedores, seriam tão abjetos quanto os burgueses.

Já em Cantão, assume a direção da Propaganda (obtendo, através da "proteção" a certos importadores de ópio, muito mais dinheiro que os US\$ 800

\footnotetext{
${ }^{116}$ IBIDEM - p. 155.

${ }^{117}$ IBIDEM - p. 158.
} 
inicialmente prometidos, e conseguindo, do mesmo modo, financiar a Propaganda) e se mostra no começo bastante animado com seu trabalho, ainda mais quando Borodine chegou, o que mostrava a preparação de um ato poderoso. Mas o narrador mostra que "puis les lettres devinrent plus rares, et c'est avec surprise que j'appris que 'le ridicule petit gouvernement de Canton' entrait en lutte contre l'Angleterre et rêvait de reconstituier l'unité de la Chine"118. Garine agora já mostra seu desinteresse e desprezo pelo que ocorria em Cantão - e se o narrador vai a seu encontro, é também apenas por motivos econômicos (estando arruinado, Garine também lhe oferece um serviço e dinheiro).

Agora temos a caracterização direta de Garine pelo narrador. Se até aqui ele apenas ouvia o que os outros personagens diziam, agora é ele que emite juízos e nos revela o passado de Garine e suas relações com Cantão e os revolucionários. Aqui conhecemos melhor esse personagem tão importante para a Revolução mas para quem ela é indiferente e até mesmo indesejada (já que a vitória significaria que os vencidos se tornaram abjetos).

E a última informação que temos do relatório da Segurança é que Garine encontra-se gravemente doente e que será obrigado a deixar logo os Trópicos, informação essa que já tinha sido dita por Meunier, mas na qual o narrador diz não acreditar.

É com essa informação que a primeira parte termina. Após as aproximações fragmentadas que temos sobre Garine, Borodine, Hong e Tcheng-daï - e principalmente sobre o primeiro, de quem o narrador muito fala no final, revelandonos sua juventude, sua vontade de poder aliada à indiferença da causa (só uma coisa lhe interessava: ser contra a burguesia) - podemos ter acesso às "Puissances", segunda parte do livro.

O narrador e Klein chegam em Cantão e a partir de então o tempo é mais distendido: ao invés das datas que corriam devagar diante da ansiedade do narrador em chegar a Cantão (e que eram registradas com curtos períodos vazios), agora temos ações que decorrem durante todo o mês de julho, sem que datas sejam determinadas.

No caminho de Chamien a Cantão, o narrador descreve a velha China, a China sem europeus, no meio de uma água amarelada, intensa, com odores de gordura, animais (gato, macaco) e com uma luz sempre ofuscante e densa... é assim que o

${ }^{118}$ IBIDEM - p. 160. 
narrador vê a China - como um mistério no qual ele adentra, algo forte, ofuscante e confuso (lugar em que os sentidos são muito exigidos e explorados). Quando chega em Cantão e é levado por um motorista das forças armadas (junto com Klein), as mesmas sensações se repetem: multidão, barulho das buzinas dos carros, lojas com grandes caracteres negros, comerciantes ambulantes. Parece-nos que sempre estamos diante de uma excitação dos sentidos que não existe na "ordenada Europa", ou da Europa que organiza seu caos, como diz o personagem chinês de La tentation de l'Occident.

Essa distinção torna-se ainda mais explícita quando eles saem do bairro comerciante e entram em um boulevard tropical com casas com jardim e sem pessoas na rua. Saindo do que é costumeiramente chinês, chegamos ao lado onde os estrangeiros moram - em um lugar vazio e ordenado, cuidado.

É nesse espaço que Borodine e Garine moram, e enquanto Klein vai até Borodine, o narrador desce na casa de Garine, onde um soldado, após examinar seus papéis, o deixa entrar. O narrador sobe uma escada e se encontra em uma sala grande, ao lado de uma outra na qual homens conversavam em voz alta, e de qual só se encontrava separado por uma cortina.

Ouvimos Garine, ainda misterioso, mas já tão próximo, insistindo no decreto que os permitirá demolir Hongkong e sendo contrário à idéia que os chineses com quem conversa propõem, a de executar os trabalhadores que furaram a greve. Ouvimos tudo isso do lugar em que o narrador se encontra, da outra sala ao lado; mas logo este decide entrar e é apresentado por Garine aos outros. No entanto, nada conhecemos dessa apresentação - o narrador só relata que houve uma apresentação, mas não a mostra, o que faz com ele permaneça, para os leitores, sem nome.

Garine pergunta ao narrador sobre os papéis que Meunier lhe confiara, do dinheiro mandado pela Indochina francesa, e lhe comunica que irão à casa de Borodine, que ficava ao lado. No caminho pelo boulevard silencioso, o narrador observa seu velho amigo e nota nele os traços físicos da doença ("chaque trait porte l'empreite de la maladie") ${ }^{119}$.

Mas antes de Borodine, quem nos aparece (saindo da casa deste) é Tcheng-daï com toda sua expressão de calma (voz fraca, lenta) mas com fala direta, precisa, que diz procurar por Garine para propor-lhe uma conversa e que passará às 17 horas para

${ }^{119}$ IBIDEM - p. 166. 
falar com ele. Ambos entram na casa de Borodine e Garine com este conversa, mas em russo (língua essa que o narrador não entende).

Ficamos então diante dos grandes personagens do livro, mas fora as descrições físicas de cada um e a impressão do narrador de que ambos conversam com certa animosidade, nada sabemos de ambos. Não temos ainda acesso ao que realmente importa - ao modo como cada um age - mas apenas a suas falas, caracterizadas como confusa (a de Garine), cortês e baixa (a de Tcheng-daï) e ininteligível (a de Borodine, que fala russo).

É só no jantar com Garine que o narrador conhece os problemas da greve: não há como garanti-la por muito tempo e os ingleses sabem disso. Por isso, para vencer a Inglaterra, seria necessário promulgar o decreto que proibiria os navios de fazerem escala em Hongkong (arruinando assim os comerciantes estrangeiros) - mas para isso Tcheng-daï precisaria estar do lado deles, o que não ocorria. Este homem é o grande líder (respeitado até mesmo por Tang - o general que vai atacar os revoltosos), a quem Garine chama ironicamente de "l'honnête Tcheng-dai" ${ }^{120}$, que deseja substituir a ação por apelos .

Nessa descrição de Tcheng-daï, Garine se volta contra sua inação, sua passividade - e estende essa característica a todos os chineses ("toutes ces villes chinoises sont molles comme des méduses. Le squelette, ici, c'est nous") ${ }^{121}$. Os chineses são vistos por Garine como passivos, moles e são os europeus que estruturam a Revolução que se prepara, dando-lhe força, sustentação e direção. Na primeira fala de Garine ao narrador, percebemos ao mesmo tempo a grande importância que este dá aos acontecimentos na China e um grande desprezo pelos chineses, medusas que se tornam fortes apenas porque são dirigidos por europeus, esses sim representando a sustentação e a ação.

Garine, líder da greve de Cantão, vê tudo da posição superior em que se encontra - e se vê como superior por ocupar essa posição. Se por um lado deseja a derrota dos comerciantes burgueses estrangeiros, por outro parece desprezar o povo que torna sua ação possível, os chineses que fazem a greve. Embora sua raiva e desprezo se dirijam a um único homem - Tcheng-daï - vemos que em vários momentos ele estende sua descrição às cidades chinesas e aos chineses, misturando um pouco as características de Tcheng-daï com as dos chineses em geral.

\footnotetext{
${ }^{120}$ IBIDEM - p. 170.

${ }^{121}$ IBIDEM - p. 170.
} 
E é sobre a vida de Tcheng-daï que Garine e o narrador conversam durante todo o jantar: ao construir hospital para os membros do partido, perde todo seu dinheiro (faz empréstimo e membros do partido se voltam contra ele - e é obrigado a vender o que tem para pagar a dívida), e pobre, mostra-se orgulhoso (sua pobreza mostra a todos sua generosidade). Autoridade moral, pretende vencer pela justiça, mas ao longo de sua vida preferiu se firmar nessa idéia que realmente vencer. E para confirmar que as descrições chinesas e Tcheng-daï se confundem no relato, Garine diz que "il lui convient d'être l'âme et l'expression d'un peuple opprimé"122. E é esse homem que se vê como a expressão do povo chinês que é preciso conquistar: intocável, um mito, perder seu apoio seria perder força na Revolução.

No dia seguinte, às 14 horas, o narrador se encontra na Propaganda, no escritório que lhe foi destinado e o qual é descrito semelhante à sala de Gérard, numa mistura de estilos e povos: retrato de Sun Yat-sen e de Lénin, figura de um pequeno chinês com uma baioneta junto a um russo e uma outra figura de um soldado europeu com metralhadoras disparando nos chineses (que representa o passado). O narrador fica ao lado da sala de Garine e em ambos os escritórios a luz amarela e densa penetra (sempre essa sensação de muita luz, muito calor, mas uma luz que ofusca, que cega, que torna tudo confuso).

Na sala ao lado Nicolaïeff (comissário da Polícia geral) conversa com Garine e diante da certeza do ataque do general Tang a Cantão, o herói pede ao comissário da Polícia que mande agentes espalhar a notícia na cidade e nos sindicatos. Garine passa a tarde toda a receber visitas e relatórios, a dar ordens; enfim, a dirigir a Revolução, a se preparar para o ataque de Tang.

Mas a descrição de todos os diálogos não faz senão preparar para a chegada prometida e aguardada de Tcheng-daï, às 17 horas, a qual se revela mais monólogo que diálogo: enquanto Tcheng-daï inicia a conversa falando dos atentados, Garine tenta falar do ataque próximo de Tang, a quem Tcheng-daï chama de homem justo e leal. Este diz que se ajudou a destruir velhos costumes chineses não deseja, no entanto, abandonar a noção de justiça e pensa que não devem atacar. Todas as "habilidades" de Garine e Borodine são reconhecidas por Tcheng-daï com ironia e desprezo e por fim, este diz que "je ne puis voir sans regret mes compatriotes

${ }^{122}$ IBIDEM - p. 171. 
transformés... en cobayes..." ${ }^{123}$ e que se é necessário enfrentar o perigo, é necessário também não procurá-lo.

O tempo todo Tcheng-daï insiste na boa característica chinesa da busca da Justiça, da espera por ela e não pela ação (que ele julga precipitada). E se até agora eram os europeus que sempre enfatizavam a distinção deles com os chineses, de modo sempre a fazerem-se superiores a estes, agora é um chinês que, com o mesmo sentimento de orgulho, afirma sua diferença dizendo que "La Chine est la Chine, et le reste du monde est le reste du monde..." ${ }^{124}$ e que a não preocupação com a justiça fará a Inglaterra perder (a longo prazo, é verdade) a luta.

Apesar da simetria de falas orgulhosas, é com uma expressão de Garine que o narrador escolhe finalizar esse assunto, e cuja intenção é desmoralizar Tcheng-daï em sua ausência, é enquadrá-lo na função dos que se acham santos e só atrapalham a ação. Assim que Tcheng-daï sai do escritório de Garine, deixando claro que não ajudará no ataque, na violência (na promulgação do decreto), este exclama ao narrador: "Bon Dieu, Seigneur! délivrez-nous des saints!"125.

É ainda sobre a oposição Ocidente x Oriente, de como este se transforma, adquirindo valores ocidentais, que Garine e o narrador falam durante o jantar, com o primeiro narrando o surgimento do sentimento da vida individual e a descoberta da morte, o que torna o chinês um bom revolucionário: a partir do momento em que esses se separam da vida chinesa da indiferenciação coletiva eles se rebelam, afirmam-se em sua individualidade revoltando-se contra o estado anterior. E é essa revolta que pessoas como Garine e Borodine precisam estimular para alcançarem a vitória, e só é possível alcançá-la por meio de pequenos atos que exaltem a importância de cada chinês e ao mesmo tempo que não os assustem com imagens repugnantes de guerra (do que a greve em Hongkong é um bom exemplo).

E após uma visita a Borodine, que estava doente, Garine confessa ao narrador que é mais hostil aos princípios estúpidos que aos detentores de poder e terra. Como a primeira parte já nos revelada, é seu ódio às idéias burguesas que o leva a agir e não qualquer ligação com as idéias dos revolucionários - o que o liga ao Kuomintang é o hábito e a necessidade de uma vitória comum. Mas se não lhe interessam as idéias revolucionárias, é certo que essa vitória não pode ter o mesmo significado para

\footnotetext{
${ }^{123}$ IBIDEM - p. 185.

124 IBIDEM - p. 186.

${ }^{125}$ IBIDEM - p. 186.
} 
ambos: Garine se une ao Kuomintang pelo enfrentamento comum, pelo desejo comum de destruir os detentores de poder, terra, dinheiro; ou melhor, nem mesmo isso é igual - se Garine deseja destruir os burgueses mais por causa de seus ideais estúpidos que pelos seus atos, aos Revolucionários importa a ação dos burgueses, e é contra ela que esses $\operatorname{lutam}^{126}$.

Os diálogos e reflexões sobre as distinções entre Oriente e Ocidente e o objetivo da luta começam a dar lugar para o relato das ações em Cantão: os terroristas (tendo Hong como um dos líderes) intensificam suas ações (a ponto de Tcheng-daï pedir sua prisão) e as tropas de Tang já estão próximas de Cantão, do outro lado do rio. Garine agora está imerso na organização de suas tropas, do ataque e defesa da cidade - o dia todo ordena ações a Nicolaïeff e a Hong (que aparece pela primeira vez mas que ainda nada fala, apenas obedece ao que Garine ordena na luta contra Tang).

Aos poucos, desempregados, grevistas, coolies, enfim, chineses se dirigem à Propaganda e pegam fuzis para ajudar a derrotar Tang (Garine desce à rua para ordenar a distribuição de armas, a qual estava sendo feita de modo desorganizado e barulhento). Do alto da Propaganda (assim como do alto do comando), Garine e o narrador olham para a rua, onde a multidão chinesa se concentra para se armar e defender as pontes, a cidade. E é lá que eles esperam - Garine continua na Propaganda enquanto os confrontos se desenvolvem; durante os ataques de Tang e as sucessivas defesas dos chineses, Garine e o narrador esperam, saindo da Propaganda apenas para conversarem com um coronel, que os avisa que Tchang Kaï-chek e suas tropas começam a se movimentar para também atacar Tang.

Duas horas depois, a espera continua mas se transforma. Tang ameaça passar uma ponte, mas logo é obrigado a retornar. O confronto começa a se mostrar monótono e a ansiedade diminui, ainda mais quando Tchang Kaï-chek chega e as tropas de Tang começam a se retirar, a fugir pelos campos. À noite, o confronto já quase não existe e não mais ameaça; no entanto, essa vitória nada significa, já que outros poderão atacar e é necessário encontrar um modo de vencer a resistência de Tcheng-daï e promulgar o decreto que proíbe os navios de aportarem em Hongkong.

No dia seguinte ao da batalha, a urgência desse decreto torna-se ainda mais patente com o número de relatórios mostrando a dificuldade financeira de se manter a

\footnotetext{
${ }^{126}$ A vitória comum a qual Garine alude deixará de ser comum no instante mesmo em que se tornar vitória - e Garine sabe disso. Como então não se sentir apartado desde já? Embora critique as atitudes passivas de Tcheng-daï, embora lute para obter a vitória, seu interesse é menos implantar uma Revolução do que destruir os princípios estúpidos da burguesia.
} 
greve. Diante disso, Garine anuncia ao narrador que vai até a casa de Tcheng-daï e na volta, após escrever todo o diálogo, lê para o narrador, como se fosse um teatro, imitando a voz de Tcheng-daï, que conta como ajudou Garine a formar e a convocar chineses para a Escola de Cadetes de Whampoa para defender mas que muitos morreram em vão (já que morreram no ataque e não na defesa). Nesse diálogo, Tcheng-daï deixa claro que não defenderá o projeto de Garine, que o combaterá porque ele não é bom pastor para o povo, já que não ama o chinês.

Mas dessa conversa pessimista, na qual Tcheng-daï diz claramente que é contra a promulgação do decreto, Garine sai otimista: se é certo que não vão obter o apoio daquele, é certo também que seu comportamento, seu pedido de prisão aos terroristas, se voltará contra ele: Hong o odeia e só é preciso esperar...

Mas Hong não odeia apenas Tcheng-daï e começa a matar burgueses e banqueiros que ajudam financeiramente a greve e o Kuomintang (e a quem Borodine e Garine já tinham pedido que não torturasse nem matasse). Ele aparece no escritório da Propaganda no dia seguinte para justificar assim seus atos: "La torture - moi je pense est, là, une chose juste. Parce que la vie d'un homme de la misère est une torture longue. Et ceux qui enseignent aux hommes de la misère à supporter cela doivent être punis, prêtres chrétiens ou autres hommes"127.

E Garine, diante da posição de Tcheng-daï de não promulgar o decreto e diante dos vários pedidos de dinheiro para a manutenção da greve geral em Cantão e Hongkong, decide abandonar esta e manter a greve apenas no porto de Hongkong ("Hongkong sans bras vaut Hongkong désert") ${ }^{128}$. E se Tcheng-daï sempre preocupou Garine, agora Hong (que tanto admira) também começa a preocupá-lo, pois percebe que foi a necessidade de ação que unia Hong à Internacional, mas que ele acha que essa age devagar demais. Garine sabe que a ruptura está próxima e ele a lamenta: "il est peu d'ennemis que je comprenne mieux..." ${ }^{129}$; a ligação de Garine com Hong é maior do que com Borodine (que até agora pouco apareceu, ainda doente), já que em Hong também se vê o desprezo pelas idéias burguesas e aristocráticas e o gosto da ação.

Borodine é um revolucionário profissional e Tcheng-daï é um pacifista profissional; nenhum parece ter paixão pelo que faz - é Garine e Hong que agem com

\footnotetext{
${ }^{127}$ IBIDEM - p. 208.

${ }^{128}$ IBIDEM - p. 209.

${ }^{129}$ IBIDEM - p. 212.
} 
raiva e desprezo, mais com sentimentos negativos que pensando na construção de algo; e é nesse desejo violento de destruição que ambos se compreendem (mesmo que Garine seja um dos líderes da greve, ele não pensa nela de forma arquitetada e otimista como Borodine pensa).

E é essa distinção que se percebe no dia seguinte, na discussão de Garine e Borodine com Hong. Se a conversa de Hong com Garine é hostil, com este tentando fazer aquele compreender que o dinheiro é importante para a Revolução e que a ação terrorista depende da polícia que ela encontra em sua frente (o que Hong logo compreende), ela não chega a ser tensa e cheia de raiva contida como é o diálogo entre Hong e Borodine, com um acusando o outro, com o primeiro dizendo que Borodine não tem medo de se fazer matar mas do resto sim, e com este dizendo que cada um tem seu papel.

Hong novamente fala e vai embora correndo. Garine pensa que logo ele matará Tcheng-daï (pois entendera que ele só conseguia matar porque a polícia ainda estava de seu lado) e decide esperar por isso. E é após essa discussão que pela primeira vez Garine fala de sua doença (antes o narrador tentara duas ou três vezes falar sobre isso mas Garine sempre fugia do assunto), de que "on croit que c'est une chose contre laquelle on lutte, une chose étrangère. Mais non: la maladie, c'est soi, soi-même..." ${ }^{130}$. Garine se define como doença, esta faz parte dele, não é algo estranho. Garine espera a questão de HongKong ser resolvida para se cuidar, mas sua doença (ou melhor, ele mesmo) não espera: antes que qualquer coisa seja resolvida, passa mal e é levado ao hospital.

E enquanto Hong agora se pronuncia publicamente contra a liderança estrangeira na Revolução, Garine permanece no hospital, onde o narrador vai visitá-lo. O doente delira, fala de seus impulsos, do processo que sofrera ainda jovem e revela que "après mon procès, j'éprouvais - mais très fortement - le sentiment de la vanité de toute vie, d'une humanité menée par des forces absurdes. Maintenant ça revient...C'est idiot, la maladie... Et pourtant, il me semble que je lutte contre l'absurde humain, en faisant ce que je fais ici... L'absurde retrouve ses droits..." ${ }^{131}$.

É contra o absurdo que Garine luta; mais que contra os burgueses ou seus princípios idiotas. Desde sua juventude, sente que a vida é vã, que tudo é controlado por forças absurdas, contra as quais é necessário lutar, mesmo sabendo que elas

\footnotetext{
${ }^{130}$ IBIDEM - p. 215.

${ }^{131}$ IBIDEM - p. 221.
} 
sempre vencerão. Na doença que é o próprio homem, o absurdo encontra seus direitos, mostra que é o vencedor. Mesmo que tenha dado esperança a homens que não a tinham (o que deve ser valorizado), é contra o absurdo que luta na China.

A ação de Garine é toda ela dirigida contra as forças que dominam a vida - por meio da ação, ele pretende se tornar dono de seus atos, fugir do controle das forças absurdas; mas a doença, que não é um corpo estranho, que é o próprio homem, aparece para simbolizar a vitória certa do Absurdo. É o próprio homem que é e anuncia a inevitabilidade de sua derrota: por mais que lute, o Absurdo vence.

E se é assim, se Garine confessa lutar contra o Absurdo, começamos a compreender melhor por que sua ligação com os revolucionários é quase nula: se eles agem juntos, nada os une além dessa ação. Enquanto esses últimos, por meio da ação, tentam realizar uma transformação social, Garine deseja vencer o Absurdo, que não pode ser vencido. Se para os revolucionários como Borodine a Revolução é uma luta social efetiva, para Garine ela não passa de um cenário no qual se desenrola a luta metafísica contra o inevitável destino humano.

Se o livro narra a Revolução Chinesa de 1925, os acontecimentos que aí ocorrem, para seu personagem principal ela não é importante. Para Garine, a luta que interessa não é contra o domínio estrangeiro na China e nem mesmo contra os princípios estúpidos que os burgueses ostentam (como ele afirmara ao narrador), mas contra o destino humano (diante do qual o cenário no qual essa luta se desenrola perde sua importância, torna-se indiferente).

Em um romance histórico que narra as greves na China em 1925 a história se nos revela indiferente: "Os Conquistadores" não é o relato da conquista efetiva do poder em Cantão mas a tentativa de se conquistar seu destino, de se fazer dono e criador dele - assim, se o livro ganha importância por tratar de acontecimentos reais, ele os relega a segundo plano, colocando, com relevo, a questão metafísica da luta contra o absurdo e a vanidade da vida humana.

Não podemos dizer nem mesmo que Garine, em sua ação histórica, realiza essa luta contra seu destino. A metafísica não parece imbricada na história, essa parece ser indiferente - em todas as ações que empreendeu (desde a juventude até agora) Garine se mostra indiferente. Suas ações, ao invés de serem o confronto contra o absurdo, parecem apenas simbolizar essa luta - e é por isso que Garine pode se mostrar tão indiferente em relação às causas e efeitos de sua ação. 
E após essa confissão, o título da terceira parte, "L'homme", adquire todo um significado metafísico que não seria possível apreender de um relato de uma revolução. A última parte do livro se refere ao "homem" e inicia-se com a morte de um: cartazes anunciam que Tcheng-daï se matara para conservar a idéia da Paz e Garine (que já saira do hospital) com Borodine, após confirmarem a notícia de que Tcheng-daï encontrava-se morto, resolvem trabalhar para colocá-la do lado dos revolucionários.

E embora a morte de Tcheng-daï tenha sido confirmada, o suicídio ainda restava em dúvida. Mesmo sem saber como morrera (e isso não parecia importar), Garine pede para que o narrador traduza para o cantonês frases que indicam o assassinato de Tcheng-daï pelos ingleses para que elas sejam impressas e coladas nos muros, a fim de ao menos neutralizarem a notícia anterior do suicídio. Como comenta bem objetivamente Garine, os dois lados tentam se aproveitar da morte de Tcheng-daï e restava a eles combater o outro grupo. Com esses cartazes (e tirando os cartazes anteriores), a morte de Tcheng-daï poderia servir para uma intenção contrária ao que este queria: a promulgação do decreto - e é para isso que Garine ia trabalhar.

Após o narrador cuidar da tradução e impressão dos cartazes, vai ao prédio da Segurança, onde Garine e Gallen combinam de encontrar um homem corajoso (Lin, chefe de um sindicato) para ser preso e acusado da morte de Tcheng-daï. Com a morte deste, fica muito mais fácil conservar sua influência para a conseqüência que não desejava - e para isso serve o trabalho da Propaganda, ainda mais quando outro general, Tcheng Tioung-ming, avança com suas tropas para Cantão. A influência de Tcheng-daï é propositalmente mantida por Garine e Borodine: esses dizem que manterão o desejo do líder chinês de prender os terroristas e com isso o Comitê dos Sete (o órgão que comanda o governo do Kuomintang) afirma que em até três dias assinarão o decreto tão exigido por Garine. Ling é então preso e interrogado, acusado de matar Tcheng-daï (era necessário que alguém fosse preso).

Hong também é preso e Garine começa a se mostrar novamente doente, cansado. Mas ainda há ameaças: Tcheng Tioung-ming avança, os ingleses de Hongkong começam a encontrar japoneses e anamitas para trabalharem no porto, e quatro homens (reféns) são assassinados, entre eles o alemão Klein.

Garine e o narrador vão até a casa ao lado do rio onde os corpos estavam. Colocados contra o muro, em pé, os corpos apresentam algo de surreal na luz que passa pelos vidros azuis. Todos torturados, apresentam feridas abertas que fazem o 
narrador se contrair. Uma mulher chega e sem ver Garine e o narrador vai direto ao corpo de Klein (era sua mulher), ajoelha em sua frente sem gritar, chorar nem rezar. "On dirait qu'elle s'est agenouillée devant les tortures que représentent toutes ces plaies et cette bouche qu'elle regarde, ouverte jusqu'au menton par un sabre ou un rasoir... Je suis certain qu'elle ne prie pas. Tout son corps tremble..." ${ }^{132}$. E diante desse espetáculo de força e de sofrimento, desse silêncio tão cheio de vozes e significados, Garine e o narrador vão embora, sem nada dizerem à mulher nem mesmo a si mesmos.

O silêncio domina e é só quando chegam na casa de Garine que este, cada vez mais enfraquecido e doente, com febre, fala da morte de seu amigo: ("J'ai eu pour lui une amitié d'homme.... $)^{133}$ e do sentido de suas ações e de todas as ações perante a morte: "ce que j'ai fait ici, qui l'aurait fait? Et après? Klein, son corps crevé partout, sa bouche engrandie au rasoir, sa lèvre pendante... Rien pour moi, rien pour les outres. Sans parler des femmes comme celle que nous avons vue tout à l'heure, qui ne peuvent rien faire de plus que flotter leur tête désespérée contre les plaies..."134.

O que é a ação diante desse corpo estraçalhado? Mesmo que a ação seja importante como a de Garine, ela se anula diante desse espetáculo paralisante que é a tortura e a morte. Teria sentido toda a luta empreendida por Garine contra o Destino Absurdo? Mesmo que o que importe seja não ser vencido, isso seria possível? E qual seria o valor dessa vitória se ela traz consigo essa forte imagem de podridão e morte?

Três dias após esses diálogos que começam a deixar ver uma certa desesperança nesse homem que ainda diz confiar no que faz, Garine é baleado quando andava de carro - e ao invés de maldizer seu opositor, elogia sua coragem (porque ele não tentara fugir) e pensa em partir e confessa ao narrador:

Mon action me rend aboulique à l'égard de tout ce qui n'est pas elle, à commencer par ses résultats. Si je me suis lié si facilement à la révolution, c'est que ses résultats sont lointains et toujours en changement. Au fond, je suis un joeur. Comme tous les jouers, je ne pense qu'à mon jeu, avec entêtement et force. Je joue aujourd'hui une partie plus grande qu'autrefois, et j'ai appris à jouer: mais c'est toujours le même jeu. Et je le connais bien; il y a dans ma vie un certain rythme, une fatalité personnelle, si tu veux, à quoi je n'échappe pas. Je m'attache à tout ce qui lui donne de la force... (J'ai appris

\footnotetext{
132 IBIDEM - p. 243.

133 IBIDEM - p. 244.

${ }^{134}$ IBIDEM - p. 246.
} 
aussi qu'une vie ne vaut rien, mais que rien vaut une vie...). Depuis quelques jours, j'ai l'impression que j'oublie peut-être ce qui est capital, qu'autre chose se prépare... Je prévoyais aussi procès et ruine, mais comme ça, dans le vague... $^{135}$.

Aqui Garine se mostra ainda mais claramente desligado de suas ações: embora a ação importe mais que a teoria, é apartada de suas concretudes - a ação importa como símbolo da luta contra as Forças Absurdas que governam a vida humana, como indício de assunção do destino e não porque terá tal ou tal efeito. Os resultados da ação não interessam a Garine, assim como seus princípios. Se inicialmente o desprezo às causas e teorias poderia revelar uma preocupação social e realista, agora vemos que a ênfase na ação desvela uma preocupação metafísica da luta humana contra seu irreversível destino. A ação parece ser, para esse personagem, o instante em que o homem se mostra dono de si, agente, jogador e não as cartas com que as Forças brincam. E nesse jogo que se mostra sempre o mesmo (o homem contra o absurdo de seu destino, o homem contra a morte), Garine vê um ritmo, uma fatalidade pessoal a qual ele não escapa. Mesmo na ação, mesmo no jogo em que se tenta vencer o destino, há uma inevitabilidade. Parece-nos que se Garine consegue tornar-se jogador é porque assim lhe é permitido: se a fatalidade é pessoal, o que diminui um pouco sua força, ela continua a ser fatalidade.

Mas mesmo nesse momento em que Garine parece compreender que o absurdo domina toda a ação, em que ele apreende que a vida não vale nada, há, por outro lado, a afirmação de que nada vale uma vida. Mesmo se a vida é governada por forças externas e absurdas, mesmo se não é possível tomá-la em nossas mãos, nada vale essa vida. Ela vale a pena ser vivida apesar (ou justamente por causa) de sua não-valia. Nesse instante no qual a doença e o ferimento parecem dominar Garine, nesse instante em que a ação parece se submeter totalmente à fatalidade, a vida aparece como um valor ao qual nada se compara. Mesmo na ruína, ela surge e parece até indicar uma certa vitória, já que o decreto é enfim promulgado.

$\mathrm{O}$ decreto que determina a proibição dos navios fazerem escala e aportarem em Hongkong é promulgado e pouco falta para que o Kuomintang chegue ao poder: basta derrotar as tropas de Tcheng Tioung-ming, o que não parece ser difícil. A doença de Garine, seus problemas pessoais dão momentaneamente lugar às vitórias da

${ }^{135}$ IBIDEM - p. 250. 
Revolução: Hongkong começa a se arruinar, parte das tropas inimigas é batida e na cidade de Cantão, vê-se em todo lugar o entusiasmo e a alegria.

Mas o narrador, já há dois meses em Cantão (estamos agora em 17/08), sentese cada vez mais isolado de tudo que vê: "jamais je n'ai eprouvé aussi fortement qu'aujourd'hui l'isolement dont me parlait Garine, la solitude dans laquelle nous sommes, la distance qui sépare ce qu'il y a en nous de profond des mouvements de cette foule, et même de son enthousiasme..." ${ }^{136}$. O narrador, assim como Garine, não compartilha da Revolução que ajudou a construir; os dois meses em Cantão mostraram mais as distâncias que as semelhanças. A vitória já apontada como certa parece ser indiferente a Garine e também ao narrador, mas não a Borodine, que usara a morte de Klein para fazer propaganda (assim como a morte de Tcheng-daï fora usada antes).

Garine se enfurece com Borodine e diz que não saiu da Europa para ir a Cantão aprender o que é "obediência" e desabafa ao narrador dizendo que "il veut fabriquer des révolutionnaires comme Ford fabrique des autos!" ${ }^{137}$. E se é verdade que cada um encara a Revolução de modo diverso, que Borodine é mais técnico e tem um interesse real na vitória dos revolucionários (implantar o comunismo na China), enquanto Garine não se liga ao destino desses; é verdade também que, segundo o narrador, o real motivo da ruptura entre ambos não é esse de quem falará no funeral de Klein (Borodine ordenou que fosse Garine, que por sua vez se recusa a ir) mas um outro mais concreto: a execução de Hong, determinada por Borodine.

Embora não pudesse ser acusado de matar Tcheng-daï nem de ter torturado Klein e outros chineses (e era possível que Hong não tenha feito esses atos), Hong fora preso e Borodine mandara executá-lo, já que mais prejudicava do que auxiliava a Revolução, matando homens que financiavam-na. Mas Garine desejava salvá-lo porque o admirava e também porque pensava que, em caso de ruptura entre ele e Borodine, com certeza Hong ficaria do seu lado (o que leva o narrador a comentar que um dos motivos de Borodine matar Hong é porque sabia disso).

Se a morte de Tcheng-daï uniu os dois líderes europeus, já que o chinês ainda defendia velhos valores chineses como "justiça", passividade e a espera, a morte do outro chinês, Hong, separa Garine de Borodine. Hong se encontrava no outro extremo de Tcheng-daï, no da ação sempre violenta e urgente, e se identificava com Garine.

\footnotetext{
${ }^{136}$ IBIDEM - p. 254.

${ }^{137}$ IBIDEM - p. 254.
} 
Dos três inimigos (nenhum realmente pensava e agia igual), Hong era quem Garine melhor compreendia e a quem admirava ${ }^{138}$.

Parece que Garine dessa vez realmente partirá. É Nicolaïeff quem o diz ao narrador, explicando que além das doenças tropicais que tem, "son temps est fini. Ces hommes-là ont été nécessaires, oui; mais maintenant, l'armée rouge est prête, Hongkong sera définitivement abbatue dans quelques jours; il faut des gens qui sachent s'oublier mieux que lui"139. E é o próprio narrador que, desejando defender seu amigo, o chama de revolucionário do tipo "conquérant", que prega o individualismo (o que era essencial para a Revolução chinesa triunfar). Mas a defesa que o narrador faz, ao insistir em seus sentimentos negativos (no ódio à burguesia), confirma ainda mais uma questão que Nicolaïeff coloca: "il y a des moments où je me demande s'il ne finirait pas comme un mussoliniste..." ${ }^{140}$.

O tempo de Garine terminou e ele sabe disso. Decide partir no dia seguinte e já começa a preparar a mala. E ao conversar com o narrador, diz que "je pensais encore à la phrase de mon père: 'il ne faut jamais lâcher la terre'. Vivre dans un monde absurde ou vivre dans un autre... Pas de force, même pas de vraie vie sans la certitude, sans la hantise de la vanité du monde..." ${ }^{141}$. É preciso viver aceitando o absurdo (e é dessa certeza que Garine tira toda sua força e sentido de sua vida), mas não se pode viver no absurdo: se por um lado é preciso aceitar o absurdo como constituinte de toda vida e ação, se é preciso aceitar que é ele quem dá sentido a tudo, é preciso, no entanto, lutar contra ele, não viver $n$ ele. É a própria absurdidade da vida que dá forças a Garine para lutar contra o absurdo. E o único modo de se defender desse absurdo, de aceitá-lo mas não viver nele é por meio da criação - "on ne se défend pas qu'en créant" ${ }^{142}$.

Mas novamente essas considerações são cortadas pela realidade, pelos acontecimentos da Revolução. E se antes, quando já estava doente, Garine de bom grado interrompia seus pensamentos e delírios para ler relatórios e agir, agora, com a viagem marcada para o dia seguinte, recebe com indiferença e mesmo com desprezo as informações de que a batalha decisiva entre Tcheng Tioung-ming e as forças

\footnotetext{
${ }^{138}$ Se Tcheng-daï e Hong têm bastante importância, se eles representam os chineses, ambos morrem. Restam somente os estrangeiros.

${ }^{139}$ IBIDEM - p. 256.

${ }^{140}$ IBIDEM - pp. $257-258$.

${ }^{141}$ IBIDEM - p. 259.

${ }^{142}$ IBIDEM - p. 260. Não se pode dizer que Garine fala da criação artística, já que em nenhum momento se refere à arte, mas é interessante notar que de todo modo, ele vê seus atos como uma criação - e é isso que permite se defender do absurdo.
} 
armadas vermelhas começava. Mas logo depois de dizer que tudo agora the era indiferente, reage com fúria, dirige seu carro com o braço esquerdo quase imobilizado por causa dos tiros que tomara, e vai ao prédio da Segurança para fazer, ele mesmo, um interrogatório a dois agentes duplos.

No momento em que vai embora, em que tudo the parece indiferente, Garine ainda encontra um instante de fúria, de ódio, e age com tamanha violência (no interrogatório, mata um dos agentes e ameaça o outro, gritando para Nicolaïeff "fousmoi la paix!") ${ }^{143}$ como se nessa ação estivesse concentrada toda sua "salvação", como se, já próximo da morte, ainda pudesse lutar contra seu destino absurdo. Nessa ação desesperada, violenta, Garine coloca tudo que resta de sua força para criar, para se defender do absurdo, para afirmar sua autoridade não só em relação à Revolução mas também e principalmente em relação à sua vida, para enfim, negar a morte que se aproximava.

Essa negatividade é visível no último diálogo com o narrador, no preparo das malas (apenas duas, que dariam para uns 3 meses, o tempo para ele "se curar" e voltar), no que encontrará em sua volta a Cantão, na desconfiança em relação a Borodine e no desejo um tanto inusitado de ir à Inglaterra, ao Império da constante violência, onde sua vontade de dirigir, determinar e constranger seriam de acordo com o país... Mas todas essas falas parecem ao narrador um esforço de Garine para se convencer de que não morrerá, de que voltará a Cantão e continuará a agir.

Durante esse triste diálogo em que um tenta se convencer de que viverá e em que o outro se esforça para não dizer que Garine vai morrer, notícias da Revolução chegam junto com um som longínquo de passos: Tcheng perde a batalha e as forças armadas vermelhas se aproximam. A vitória da Revolução Chinesa é anunciada mas parece não ter mais valor para Garine nem para o narrador. Mesmo o entusiasmo de Garine ao prever que em menos de um ano conquistariam Xangai é falso.

No cenário de despedida e de morte, a vitória social não tem sentido algum, serve, aliás, para tornar ainda mais triste e trágico o destino de um de seus líderes:

Lentement, mordant sa lèvre inférieure, il sort de l'écharpe son bras blessé, et le lève. Nous nous étreignons. Une tristesse inconnue naît en moi, profonde, désespérée, appelée par tout ce qu'il y a là de vain, par la mort présente... Lorsque la lumière, de nouveau, frappe nos visages, il me regarde.

${ }^{143}$ IBIDEM - p. 263. 
Je cherche dans ses yeux la joie que j'ai cru voir; mais il n'y a rien de semblable, rien qu'une dure et pourtant fraternelle gravité ${ }^{144}$.

Não é sobre os acontecimentos na China que o livro de Malraux trata - mesmo que tudo ali se passe é sobre Garine, personagem tão solitário e "conquistador", que a última cena se centra. Ao invés da vitória social, a derrota pessoal; ao invés da vida, a morte: a fraternidade triste que se vê entre o narrador e Garine mostra a presença forte e opressora da morte, e em nada nos remete à China, à greve ou à revolução.

O livro termina na questão pessoal e dramática do homem que lutou a vida toda contra o absurdo e agora vê tudo se integrar a ele. A morte e o destino aparecem e predominam, não deixando mais lugar para a história, para a realidade.

A fraternidade viril presente nesse abraço não é suficiente para eliminar o sentimento sempre presente de solidão; ao contrário, ela o estimula: "Parallèle à cette idée de la fraternité et souvent accentué par celle-ci surgit le problème de la solitude, de l'individu et de la conscience individuelle" ${ }^{145}$. O abraço e o momento de despedida não diminuem a extrema solidão à qual Garine se entrega nesse momento final de sua vida. E diante dessa Morte que se mostra tão certa e próxima, nem o olhar amigo e fraterno do narrador nem mesmo a vitória da Revolução conseguiriam desviar de seu último confronto.

É essa luta perpétua que interessa a Garine e não o destino da Revolução, à qual se ligou indiferentemente, como fizera durante toda sua vida. O que lhe interessa é a ação, pensada como um modo de afirmar sua marca, sua determinação contra o absurdo que domina toda vida. E nessa luta não há como encontrar companheiros: é preciso enfrentar sozinho as forças absurdas, sem amigos e sem apoio da história. A Revolução Chinesa não é vista por Garine como o lugar no qual pode se desenvolver esse confronto mas sim como apenas um símbolo dele, e é só assim que podemos compreender sua total indiferença em relação às conseqüências dela.

Embora Malraux, um ano após a publicação do livro, afirme, contra os críticos -que vêem em Garine um personagem de um individualismo extremamente violento e elitista - que seu personagem tem um caráter anti-individualista, com vontade de criar uma coletividade consciente dela mesmo, e chega a dizer que "le sentiment essentiel

\footnotetext{
${ }^{144}$ IBIDEM - p. 269.

${ }^{145}$ HARRIS, G. André Malraux: l'éthique comme fonction de l'esthétique - p. 26.
} 
de Garine est la fraternité d'armes. Il n'est pas possible qu'un homme qui mène pendant quatre ans, avec d'autres hommes, un combat qu'il a choisi, soit indifferént à leur sort"146; concordamos com o que boa parte dos críticos diz de Garine: é um aventureiro solitário (cf. Albérès In La révolte des écrivains d'aujourd'hui), um revolucionário romântico, um conquistador (cf. Ayher - "Les premiers romans" In Malraux: être et dire), individualista (cf. Mauriac, C. In Malraux ou le mal du héros), conquistador doente e provisório (cf. Goldmann In Sociologia do romance).

O modo como Garine fala dos chineses e da China (sempre a desprezá-los, a criticá-los, a moldá-los de acordo com sentimentos europeus de morte, individualismo, coragem e ação), da própria Revolução (sempre vendo-a do alto de sua posição de líder, não participando dos confrontos diretos, desprezando as conseqüências dela e os motivos pelos quais a maioria luta, desprezando até mesmo aqueles que defende) e dos comunistas (também é contra suas ortodoxias e não se liga a suas vontades) nos leva a pensar, junto com os críticos e contra Malraux, que esse personagem não se encontra ligado à Revolução e à sorte dela. Podemos perceber, no modo como se relaciona com a China, os chineses e a revolução, um elitismo solipsista desse personagem que diz lutar a luta mais vã: contra o destino certo e absurdo, a morte.

Nada no romance - nem os conteúdos da fala nem o modo de relacionar-se com os outros - nos leva a concordar com a afirmação de Malraux de que Garine se importa com a sorte da Revolução ${ }^{147}$. Les Conquérants, se fala da Revolução Chinesa, se tem o grande mérito de trazer a história como tema da ficção, acaba, em sua forma narrativa, por condenar a história a um segundo plano diante das questões metafísicas perante o destino inevitável e absurdo de todo homem.

O livro só pertence superficialmente à história, esta se revela pano de fundo das questões que o personagem Garine põe e enfrenta na mais extrema solidão. A história se mostra como um caos ao qual o personagem principal não adere: se age, se luta contra os burgueses, se suas ações têm conseqüências concretas, elas the são, no entanto, indiferentes. Garine não deseja e parece não se envolver nesse caos e desordem que toda vivência traz e é.

\footnotetext{
${ }^{146}$ MALRAUX. Oeuvres Complètes - p. 292.

${ }^{147}$ É o próprio Malraux quem diz, vinte anos depois, em um posfácio ao livro, que "ce livre n'appartient que bien superficiellement à l'histoire. S'il a surnagé, ce n'est pas pour avoir peint tels épisodes de la révolution chinoise, c'est pour avoir montré un type de héros en qui s'unissent l'aptitude à l'action, la culture et la lucidité", dando, desse modo, mais razão aos comentadores que a ele mesmo. (MALRAUX. Oeuvres Complètes - p. 271).
} 
E qual seria o papel que a arte poderia exercer nesse mundo caótico?

Ao contrário dos contos de juventude, nos quais a arte sempre aparecia como uma tentativa abstrata de fugir desse mundo e de criar um outro no qual a ordem prevalecesse, em Les Conquérants ela nunca aparece diretamente. Apenas em dois momentos podemos verificar uma referência indireta às artes, e sempre através de Garine - ainda na primeira parte, na qual o narrador se lembrava da juventude de Garine, temos o relato que esse jovem estudante dissera que apenas as Memórias eram livros que valiam a pena ser escritos, revelando, assim, um culto de Garine às grandes ações de um grande chefe. O jovem Garine não mostra ter apreço pelas ficções - o que o atrai é a ação, que não é, no entanto, uma inserção inevitável na concretude histórica mas um meio de se mostrar como dono de si mesmo, como jogador e não como as cartas do jogo que a absurda morte joga.

É só próximo da morte que Garine diz ao narrador que a única maneira de se defender do absurdo é criando. Embora não esteja se referindo propriamente à arte e esteja falando de suas ações, podemos dizer que toda arte, por também ser criação, teria também essa função de possibilitar uma defesa em relação ao absurdo. Do mesmo modo que as ações serviriam para impor uma marca pessoal de ordem nesse mundo que nos parece tão caótico nas mãos de não se sabe o que (com a morte de Deus decretada, o mundo não mais lhe pertence. Mas também não nos sentimos, nós, seres humanos, donos e responsáveis pelo mundo), a arte também exerceria essa função.

E nem poderia ter outra. Na medida em que a história é menosprezada, na medida em que ela se mostra apenas como o cenário indiferente no qual a ação contra o poder do destino se desenrola, a arte só poderia ter o mesmo papel. Tanto a conquista quanto a arte seriam modos que o homem encontraria para se defender do absurdo e do destino, um modo de garantir uma certa perpetuação.

E embora a edição final quase não se refira à arte, nos manuscritos abandonados Garine fala diretamente de Michelângelo, de como este deseja fugir e o faz por meio das cores e do mármore; e que ele o consegue. "Et malgré sa vie désespérée il est pour moi un triomphateur" ${ }^{148}$. Nesse trecho em que o jovem Garine fala diretamente da arte, podemos ver que ela significa fuga, defesa - e que ao menos Michelângelo conseguiu triunfar.

${ }^{148}$ IBIDEM - p. 1056. 
A arte e ação parecem ser, ao menos na perspectiva dominante do romance (que é a de Garine), meios de defesa e de fuga desse mundo tão caótico em que a Europa e também o Oriente se encontravam no entre-guerras. Parece-nos que Malraux continua com a mesma concepção que vimos nos contos de juventude: a arte, como criação, identifica-se com a ação, mas com uma ação desligada da concretude histórica, indiferente, transcendente.

Diante do caos, apenas uma negação abstrata (a ponto de tornar todo o real indiferente) poderia restituir uma certa ordem e sentido às coisas e ao homen. Ao menos nesse ponto concordamos com Denis, B. em seu livro Literatura $e$ engajamento de Pascal a Sartre, no qual ele diz que "a literatura engajada, tal como Malraux a pratica, transcende os fatos e a experiência para dotá-los de uma significação universal - a revolução não é nada mais do que o avatar contemporâneo do eterno enfretamento trágico do homem com o destino e a história" ${ }^{149}$.

A citação parece-nos claramente mostrar qual o sentido que a arte e a ação têm para o ainda jovem Malraux que acabara de voltar da Indochina: é a transcendência que permite doar significação aos fatos, mas o modo como escreve seu primeiro romance nos faz pensar que nesse ato de transcendência (por meio da criação), o homem se esquece que fizera isso para significar os fatos e a experiência, e então torna insignificante esse ato de significar, fazendo com que o real se torne apenas o símbolo do eterno enfrentamento trágico com o destino. Se a busca inicial da transcendência é buscar o sentido e a ordem do real que a caótica realidade não dá nem permite, nesse movimento o real deixa de interessar e dá lugar ao enfrentamento inevitável e vão contra o mais absurdo de todos os fatos: a Morte.

E no romance seguinte, La Voie royale, justamente por não relatar fatos próximos aos reais (ao menos em sua segunda parte), essa questão metafísica se torna muito mais explícita e visível.

\footnotetext{
${ }^{149}$ DENIS, B. Literatura e engajamento de Pascal a Sartre - p. 260.

Mas se concordamos com essa descrição, não pensamos, porém, que Malraux foi quem "melhor" conciliou engajamento político e literatura (como o autor diz depois), mesmo porque, como já mostramos na dissertação de mestrado, sua noção de engajamento não pode se aplicar a muitos autores aos quais ele a aplica, como é o caso de Sartre.
} 


\section{B) La Voie Royale}

Antes de publicar La Voie Royale, em 1928, Malraux publica um pequeno conto, no mesmo estilo dos contos de juventude: Royaume-farfelu, e assim como os contos vistos por nós, trata-se de uma aventura cheia de derrotas ${ }^{150}$.

E se tanto Les Conquérants quanto Royaume-farfelu foram publicados em 1928, La Voie Royale é de 1930 (também publicado por Bernard Grasset, embora o autor já estivesse ligado à Gallimard). Talvez justamente por causa de sua viagem, pela imagem de homem corajoso que ajudou na Revolução Chinesa publicando jornais que incentivavam-na (o que, como mostra Harris, não é verdade), Malraux seja tão solicitado após a volta para a França.

Avant son départ pour l'Indochine, l'homme était connu dans les salons littéraires de Paris pour sa conversation brillante; sa réputation d'écrivain était celle d'un poète d'avant-garde, quelque peu lié aux cubistes littéraires. Son ami Marcel Arland le décrit comme un homme qui préférait cacher son intelligence et son profond malaise métaphysique sous 'un masque un peu froid'. Quand il revient d'Indochine, en 1926, ce n'est plus le même homme. Son séjour de deux ans en Asie l'a profondément marqué, aussi bien sur le plan intellectuel qu'artistique. Son activité de journaliste à Saigon ne l'a pas seulement éveillé à certaines réalités politiques et sociales, elle l'a encouragé à 'essayer' une écriture qui était bien loin de l'imaginaire un peu ésotérique de la poésie d'avant-gard ${ }^{151}$.

Mas se Les Conquérants tratava dos acontecimentos da greve em Cantão, da relação entre o Kuomintang e o Partido Comunista Chinês, La Voie Royale fala de uma aventura mais individual e menos política. Se no primeiro livro vimos que o que importava a Garine era a luta metafísica contra o destino e a morte (o que o faz parecido com os personagens de La Voie Royale), o cenário era urbano, político, relatava lutas pela obtenção do poder. E todo esse cenário desaparece nesse segundo livro; e com ele também a questão que tanto atraiu os leitores do outro livro: a do partido comunista e a implantação do comunismo em outros países (e é por isso também que muitos consideram La Voie Royale um livro menor).

\footnotetext{
${ }^{150}$ A forma e o conteúdo desse conto se assemelham muito com os contos de juventude, o que mostra que, se Malraux escolheu o romance e não mais o conto após a viagem à Indochina, essa escolha não implica a condenação da escolha anterior. Malraux reconhece que o fantástico fora uma escolha errada, mas nem por isso o elimina.

${ }^{151}$ MALRAUX. Oeuvres Complètes, p. 1163.
} 
A aventura de Claude Vannec (um dos personagens principais) não tem implicação histórica nenhuma (roubar ou não estátuas e baixo-relevos na selva cambojana em nada alteraria a colonização ou o modo de vida dos colonizados) e a de Perken (o outro personagem principal), embora esteja ligada à sorte dos indígenas e selvagens, também mostra não mais influenciar tanto na colonização (embora tenha sido importante, o livro nos mostra o declínio de seu poder) ${ }^{152}$.

O livro narra a aventura de Claude em busca de estátuas no meio da selva, a mesma viagem que Malraux empreendera em 1923. Estreitamente ligado à biografia do autor, o romance narra as aventuras em busca de estátuas e baixo-relevos e os desafios que uma selva desconhecida oferece a seus desbravadores. Nesse sentido, uma influência literária salta aos olhos: há muitas semelhanças nessa selvageria, na escuridão, medo e loucura em busca do poder, com o livro $O$ coração das trevas de Conrad. Como diz Langlois em Notice de Oeuvres Complètes, o gênero literário a que Malraux recorre é antigo (o romance de aventuras exóticas), mas o conduz à metafísica: "En réalité, Malraux va créer un nouveau roman où l'aventure 'exotique' conduira à la métaphysique"153. É por esses motivos que normalmente La Voie Royale é desprezado. A maioria dos comentadores consideram-no um livro menor e dão mais ênfase para Les Conquérants e La Condition Humaine. Por falar de uma aventura na selva mas conduzi-la para questões metafísicas, por "esquecer" a grande questão política e social presente no livro anterior, principalmente a questão do comunismo, La Voie Royale é considerado um livro menor. Mas pensamos que, mesmo em um cenário diferente e com um "gênero" diferente, esse livro se assemelha e muito ao livro anterior e mesmo com o posterior.

A primeira parte do livro, dividida em quatro capítulos (dessa vez não há nomes nem datas, apenas os números para distinguir os capítulos), relata, através de um narrador em terceira pessoa (não se trata mais de um narrador-personagem como é o caso de Les Conquérants), as impressões de Claude ainda no navio e seu encontro com Perken e a proposta de procurarem juntos as estátuas e baixo-relevos. Se a partir da segunda parte os personagens já se encontram no meio da selva, nessa primeira parte eles aparecem no navio e na cidade. Antes de mostrá-los inseridos no ambiente

\footnotetext{
${ }^{152}$ Embora em Oeuvres Complètes se diga que o aspecto político do livro, a colonização, não é negligenciado, pensamos que aqui ele importa ainda menos que em Les Conquérants.

${ }^{153}$ IBIDEM - p. 1132.
} 
selvagem, que excita o medo e a loucura, o narrador os mostra em ambientes mais "normais", nos quais, porém, a obsessão já se mostra presente.

É, aliás, uma das primeiras informações que o narrador nos dá de Claude: "cette fois, l'obsession de Claude entrait en lutte" ${ }^{154}$, descrevendo como esse, no meio da noite escura, olhava e tentava vislumbrar um outro homem, que falava sobre o erotismo e o sexo, e principalmente sobre o papel que a imaginação tem no masoquismo. Perken (esse é o nome do homem que fala e mal se deixa ver) diz "L'imagination, quelle chose extraordinaire! En soi-même, étrangère à soi-même... L'imagination... Elle compense toujours..." ${ }^{155}$.

A imaginação, para Perken, sempre compensa, e é nesse barco parado no cais que escolhe uma jovem que não parece estar feliz. Uma mulher lhe oferece uma jovem que sorria, mas ele a descarta, prefere uma que não sorri, que parece não se divertir. E diante dessa preferência pela tristeza, pelo não-sorriso, Claude fica a pensar, segundo o narrador, se Perken não seria sádico, ainda mais com todas as histórias que se diziam da lenda Perken, do homem que realizava missões em tribos insubmissas, que controlava tribos, que mantinha relações cordiais e ao mesmo tempo ameaçadoras com o governo de BangKok... esse homem tão poderoso (embora já estivesse em declínio) e corajoso seria sádico? Mas Claude pensa que não, que não é o sadismo que o domina, mas outra coisa.

E é o próprio Perken que começa a falar de masoquismo, que o essencial é não conhecer a parceira, já que eles só lutam contra eles mesmo - e dá o exemplo de um homem que conhecera, que se fizera amarrar, nu, por uma mulher, em um quarto escuro, por uma hora... e nada mais. Esse é para Perken o exemplo de uma perversão pura, de um masoquista que sabe ser seu próprio inimigo e que usa sua imaginação para lutar consigo mesmo (e depois Claude saberá que esse homem é Grabot, o homem que eles irão procurar no meio da selva). Basta ser amarrado nu que toda a luta se faz; a mulher não é senão o "outro sexo", aquela que não deve ter vida particular: ela é apenas o meio para que essa luta poderosa do homem contra ele mesmo se desenrole.

\footnotetext{
${ }^{154}$ MALRAUX. La Voie Royale - p. 371.

${ }^{155}$ IBIDEM - p. 372.
} 
Perken, após esse comentário, dorme e deixa Claude sozinho com seus pensamentos e obsessões ${ }^{156}$. O narrador nos mostra que elas têm relação com questões arqueológicas do Sião e de Camboja, da estrada real abandonada, e mostra as inseguranças de Claude: quantas noites, extenuado, deverá vigiar em meio à selva cheia de mosquitos, ou dormir tendo de confiar em guias? Claude sabia que Perken poderia ajudá-lo, já que conhecia o país. E sua admiração por esse homem que tanto fez mas que não desejava de maneira alguma vangloriar-se de seus feitos crescia a cada dia - e isso porque Claude se via em Perken, identificava-se com muitas angústias que o outro mostrava sentir: "il [Claude] y devinait que cet homme aux cheveux presque gris [Perken] aimait bien des choses qu'il aimait aussi"157 e "chaque jour la ressemblance que Claude avait pressentie était devenue plus évidente, accentuée par les inflexions de la voix de Perken, par sa façon de dire 'ils' en parlant des passagers - et peut-être des hommes - comme s'il êut été séparé d'eux, par son indifférence à se définir socialement" ${ }^{158}$.

Claude não só se identifica com Perken por amar as mesmas coisas, por ver nele o "homem decomposto por sua esperança", mas também pela solidão e isolamento que o outro mostrava sentir. Claude via em Perken uma indiferença em se definir socialmente, e talvez, por isso mesmo, se sentisse diferente dos outros passageiros e até mesmo dos outros "homens".

Unidos pela comum solidão, Claude via em Perken o seu próprio destino, "vers la lutte de celui qui n'a pas voulu vivre dans la communauté des hommes, lorsque l'âge commence à l'atteindre et qu'il est seul"159. Perken, mais velho que Claude, aparece, aos olhos deste, como seu futuro - e seu passado (a ida da Europa até o Oriente, as conquistas e domínios sobre tribos insubmissas na selva de Camboja e Laos) revela o presente de Claude e sua ânsia de não viver na "comunidade dos homens".

Sem que Perken saiba, Claude começa a ver nele seu guia ${ }^{160}$. E pelo capitão do barco, Claude descobre que o dinamarquês Perken estava lá (a serviço do governo de

\footnotetext{
${ }^{156}$ Embora sempre apareçam os pensamentos dos personagens, os comentadores dizem que o papel da vida psíquica é reduzido ao mínimo, que os pensamentos se limitam a constatar a ação à qual estão ligados.

${ }^{157}$ MALRAUX. "La Voie royale" In Oeuvres Complètes, p. 375.

158 IBIDEM - p. 376.

${ }^{159}$ IBIDEM - p. 377.

${ }^{160} \mathrm{E}$ essa imagem do homem mais velho que orienta um personagem mais novo começa a ser freqüente na obra de Malraux: se em Les Conquérants o comerciante Rebecci cria o terrorista Hong, em La Voie Royale é Perken quem aparecerá, de forma menos doutrinária, como "guia espiritual" de Claude. E depois
} 
Sião, mas de uma forma um tanto obscura, como sempre) para procurar um homem que sumiu na floresta em algum país insubmisso... E um comentário um tanto desconexo, que deixa ver ainda mais a estranheza e particularidade desse indivíduo (a de que agora ele se interessava por dinheiro, coisa que não lhe interessava antes), faz com que Claude pense ainda mais na sua identificação e união com o solitário e "excêntrico" dinamarquês. Para aquele, "Perken était de la famille des seuls hommes auxquels son grand-père - qui l'avait élevé - se sentît lié. Lointaine parenté: même hostilité à l'égard des valeurs établies, même goût des actions des hommes lié à la conscience de leur vanité: même refus, surtout" ${ }^{161}$.

Cada vez mais Claude vê em Perken um certo parentesco, uma grande semelhança não só com ele mas também com seu avô, que o criara após a morte de seu pai e sua mãe, um homem que viveu indiferente a quase tudo, que acolhia a todos não por compreendê-los e amá-los, mas porque tudo era desprezível e todos se identificavam nessa indulgência odiosa; um homem, enfim, que viveu mais com os mortos e as lembranças que com os vivos... É, pois, nesse avô já morto e em Perken presente que Claude vê seu futuro - e é apenas à vida de seu avô que pode recorrer para opor uma experiência à vivida por Perken. "Comme si tous deux se fussent exprimés par paraboles, il s'approchaient de plus en plus l'un de l'autre, cachés sous les souvenirs"162. Lembranças, solidão e deslocamento unem Claude e Perken nesse barco no qual ambos viajam sem saber o que cada um fará.

O barco atraca em um porto e Claude pergunta a um homem sobre os transportes que pode utilizar na floresta (carroça, que parece não conseguir carregar as pedras que ele deseja, e elefante), e informa até onde deseja ir: à região extremo-norte de Angkor, informação diante da qual o homem se espanta e diz: "Un Blanc qui tente ça sans camarade est foutu" ${ }^{163}$.

Claude decide então procurar o dinamarquês para lhe fazer uma proposta, mas antes é este quem pergunta a Claude o que significava chegar, o qual responde: "agir au lieu de rêver"164. Para Claude chegar a seu destino é enfim agir, é deixar de lado todos os livros, a teoria, para agir, realizar algo.

veremos que em La Condition humaine essa imagem também aparecerá - Gisors, em sua sabedoria e velhice, será o guia e iluminador de quase todos os personagens do livro. Essa figura do líder e guia espiritual parece ser fundamental para Malraux.

${ }^{161}$ IBIDEM - pp. $378-379$.

${ }^{162}$ IBIDEM - p. 382.

${ }^{163}$ IBIDEM - p. 385.

${ }^{164}$ IBIDEM - p. 386. 
Perken, porém, logo descarta essa visão romântica e diz que chegar é perda de tempo, mostrando, assim, sua indiferença em relação a quase tudo. Mas em seguida Claude fala diretamente da possibilidade de encontrar dinheiro em meio aos insubmissos, em templos abandonados - e se no início Perken mostra não acreditar nessa história, aos poucos, com as informações detalhadas que Claude lhe dá, passa a ficar interessado.

Claude mostra o mapa arqueológico que guardava em sua cabine, os vários pontos ao redor da Estrada Real (La Voie Royale) que ligava Angkor aos lados da bacia de Ménam, que eram templos abandonados e mal explorados, como diziam os vários documentos do Instituto Francês e os relatos dos antigos aventureiros (aos quais ele teve acesso por saber o sânscrito, que aprendera nas Línguas Orientais). Perken percebe que a aventura era bem traçada e que o projeto não era fantástico, e que além disso tinha permissão do Ministério francês para fazer a procura arqueológica. E mesmo sabendo que a administração francesa no Oriente criará problemas, Perken diz que o maior problema será conseguir continuar na floresta, devido às febres, doenças, insetos e aos moïs (povo selvagem). E se Perken concorda em participar da aventura, é porque também tem uma missão por aqueles lados: "Pourtant, comprenez bien que si j'accepte, c'est avant tout parce que je dois aller chez les Moïs"165 e "je ne saurai exactement où je vais qu'à Bangkok: je vais chercher rechercher - un homme pour qui j'avais une grande sympathie et une grande méfiance..." ${ }^{166}$.

E do motivo preciso dessa aventura uma outra questão é colocada por Perken, questão mais profunda, saber o que Claude espera de sua vida, e este diz saber principalmente o que não espera dela e que "ce n'est pas moi qui opte: c'est ce qui résiste (...) à la conscience de la mort" ${ }^{167}$.

Claude revela assim que sabe o que não espera da vida e que se não é agente de sua vida, se não escolhe seus atos, ao menos resiste à consciência da morte: o que resiste a essa consciência é o que resta, é o que ele vive. No fundo, é a consciência da morte quem escolhe, quem opta - apenas o que resiste a ela é capaz de impor-se à vida de Claude, de determiná-la. Mais que lutar contra as idéias burguesas de revolta, de

\footnotetext{
${ }^{165}$ IBIDEM - p. 392.

166 IBIDEM - p. 392.

${ }^{167}$ IBIDEM - p. 392.
} 
honra, sua inimiga é sua dona: a consciência da morte, morte essa que se revela para Claude como decadência.

E se Perken entende tão bem essa luta vã contra a morte, ele a significa, porém, de outro modo: "Vieillir, c'est tellement plus grave! - Accepter son destin, sa fonction, la niche à chien élevée sur sa vie unique... On ne sait pas ce qu'est la mort quand on est jeune..." ${ }^{168}$.

Como decadência ou velhice, ambos se revelam obcecados pela morte, fugindo dela e a procurando. E se desde o início Claude sentia-se ligado a Perken, é só agora que ele descobre o que realmente os unia: "Et tout à coup, Claude découvrit ce qui le liait à ce homme qui l'avait accepté sans qu'il comprît bien pourqoui: l'obsession de la mort" 169 .

O narrador continua a nos relatar os pensamentos angustiados de Claude, suas lembranças de como tanto pensara nessa questão da morte e o quanto odiava a "saída" encontrada por seus amigos:

Pourquoi travaillaient-ils, eux? Pour gagner en considération. Il haïssait cette considération qu'ils recherchaient. La soumisson à l'ordre de l'homme sans enfants et sans dieu est la plus profonde des soumissions à la mort; donc, chercher ses armes où ne les cherchent pas les autres: ce que doit exiger d'abord de lui-même celui qui se sait séparé, c'est le courage. Que faire du cadavre des idées qui dominaient la conduite des hommes lorsqu'ils croyaient leur existence utile à quelque salut, que faire des paroles de ceux qui veulent soumettre leur vie à un modèle, ces autres cadavres? L'absence de finalité donnée à la vie était devenue une condition de l'action ${ }^{170}$.

Claude pensa que se submeter à ordem, desejar a consideração, é se submeter à morte - e como ele deseja o contrário disso, decide procurar suas armas onde os outros não a procuram, ou ao menos onde poucos a procuram. Se o que a sociedade faz é se submeter à morte, é necessário separar-se dela, isolar-se, fazer o que ela não faz, ir em busca de outras questões e lugares. E para esse deslocamento total é preciso ter coragem, coragem para assumir que não há uma finalidade já dada à vida. É preciso separar-se dessa sociedade que impõe ordens, é preciso agir sozinho e no meio de uma selva no Oriente.

\footnotetext{
${ }^{168}$ IBIDEM - pp. $393-394$.

${ }^{169}$ IBIDEM - p. 394.

${ }^{170}$ IBIDEM - p. 394.
} 
Claude tenta fugir das normas impostas por sua sociedade ocidental européia, e para isso volta-se para o Oriente, lugar no qual ainda seria possível fugir ao modelo que reinava na Europa. Sua vontade é de possuir mais que a si mesmo (é, assim como deseja Garine em Les Conquérants, deixar uma cicatriz, uma marca): "Posséder plus que lui-même, échapper à la vie de poussière des hommes qu'il voyait chaque jour..."171.

Mas o pensamento de Claude é interrompido e o narrador passa então a relatar as ações dos dias seguintes e a chegada ao destino inicial, Saigon. A chegada é vista por Claude com alívio, como o real início da ação. Do mesmo modo que o narrador em Les Conquérants via a aproximação a Hongkong como a chegada ao real e à ação, ao que realmente lhe interessava, Claude angustiava-se com a viagem, com a espera pela ação sem ainda poder agir, tendo apenas que esperar passivamente.

Claude vai ao Instituto Francês de Saigon e conversa com o diretor Ramèges sobre sua viagem e teoria sobre a arte: Claude expõe que os museus são lugares nos quais as obras do passado, tornadas mitos, dormem esperando que os artistas lhes dêem uma existência real. E se essa obra feita em outra era e por outra civilização é capaz de tocar alguém, é porque o artista tem esse poder de ressurreição. Mesmo que uma civilização seja impenetrável a uma outra, os objetos persistem e podem ser compreendidos a partir do instante que nosso mito se identificar com o dessa outra civilização.

E se Ramèges sorria ao ouvir essa teoria, o narrador nos conta o que Claude pensava: "Il me prend pour un amateur de théories, pensa Claude (...) Il me comprendrait tellement mieux s'il sentait que ce qui m'attache lá c'est l'acharnement des hommes à se défendre contra leur mort par cette éternité cahotée" ${ }^{172}$.

As obras de arte mostram o desespero com que os homens tentam se defender contra sua morte: através da obra (pelo que Claude chama de eternidade caótica) tornada mito e dormindo nos museus, o homem consegue, de certo modo, garantir sua eternidade, a realidade de sua civilização já morta. Por meio da obra de arte, das estátuas nos templos abandonados, o homem tenta desesperadamente se defender contra a morte - e é isso que interessava a Claude, o homem que, por meio de sua ação, também deseja o mesmo.

${ }^{171}$ IBIDEM - p. 395.
${ }^{172}$ IBIDEM - p. 398. 
Essas questões teóricas logo dão lugar às questões práticas, de como o Instituto pretende ajudar Claude (meios para requisitar condutores de carroças) e dos perigos que esse vai enfrentar. Um comentário de Ramèges surpreende e enfurece Claude: o Instituto permite que Claude leve charretes necessárias ao transporte da bagagem e dos condutores, mas que as pedras não podem mais serem transportadas. Os objetos que desejava descobrir não podem ser tirados do lugar, deverão permanecer "in locu". Ele apenas deverá fazer um relatório do que encontrou e enviálo ao Instituto.

E essa ordem é repetida depois que Claude e Perken se encontram e começam a viagem. Em Angkor um delegado fornece a Claude os documentos de que vai precisar, incluindo uma carta na qual se dizia que todo monumento, descoberto e a descobrir, situados sobre os territórios das províncias de Siem Reap, Battambang e Sisophon, são monumentos históricos; e também o alerta da presença de Perken, deixando claro que o dinamarquês esconde algo e pode a todo momento trair qualquer um (afinal, por que um funcionário siamês pediria metralhadoras para a França?), mas nosso personagem não considera as duas advertências dadas pelo delegado e decide continuar a viagem em busca de estátuas e de baixo-relevos dos templos abandonados para vendê-los na Europa (mesmo sabendo agora ser proibido, não iria desistir).

Parados à noite em um bangalô para descansar, Claude conta a Perken a conversa que teve com o delegado e afirma que "nous jouons ensemble notre vie; je suis ici pour vous aider, non pour vous demander des comptes. Si vous avez besoin de mitrailleuses, je regretterai seulement que vous ne m'en parliez pas, parce que j'aimerais à en trouver pour vous (...). Comprenez-moi. Si j'accepte un homme, je l'accepte totalment, je l'accepte comme moi-même" ${ }^{173}$. Claude confia em Perken e o aceita totalmente, e diante dessa expressão de amizade e confiança, Perken diz que deseja que Claude morra jovem e nunca descubra o que é ser prisioneiro de sua própria vida, e conta sua relação com Sarah e com a selva: "être roi est idiot; ce qui compte, c'est de faire un royaume" e

je voulais... une force militaire, d'abord. Grossière mais rapidement transformable. Et attendre le conflit inévitable par ici (...). Alors, le jeu pourrait être joué. Exister dans un grand nombre d'hommes, et peut-être pour longtemps. Je veux laisser une cicatrice sur cette carte. Puisque je dois jouer

${ }^{173}$ IBIDEM - p. 410. 
contre ma mort, j'aime mieux jouer avec vingt tribus qu'avec un enfant... Je voulais cela comme mon père voulait la propriété de son voisin, comme je veux des femmes ${ }^{174}$.

Perken mostra o desejo de deixar uma cicatriz, uma marca (tal como Garine já tinha mostrado em Les Conquérants) e que na luta contra a morte pensa ser melhor "jogar" com vinte tribos que com um filho. Se os homens que têm filhos podem "transmitir" a esperança da vitória para seus filhos, Perken não deseja essa "saída": prefere jogar sua esperança nos armamentos e defesa das tribos contra os colonizadores, ou melhor, preferia, já que as linhas das estradas de ferro em breve estarão prontas e não haverá mais lugar para as tribos insubmissas.

Mas o narrador diz que Claude não acredita muito nessa apatia e resignação de Perken, em seu abandono. Claude pensa que Perken deseja se convencer disso, de que deseja a paz. E Perken continua a falar, agora de sua missão: a de encontrar Grabot, um homem que também conhece bem o país e que tem contas a acertar consigo mesmo (um homem que chega a se destruir por raiva de outrem, como quando se cegou de um olho para se "vingar" de um médico major que não o tinha "reconhecido"). É esse homem que se "perdera" na selva que Perken e Claude vão procurar depois de acharem os templos, mesmo porque ele fora perto de Dang Rek, a mais ou menos $50 \mathrm{~km}$ do itinerário que eles farão.

Essa primeira parte de La Voie Royale termina com Claude e Perken amigos, unidos nessa fraternidade no combate à morte e na aventura em busca de estátuas e de Grabot. Com a amizade firmada e estabelecida, ambos entram na floresta - cenário da segunda parte do livro, que relata a busca pelos templos.

O narrador descreve a floresta sempre pelos olhos virgens de Claude, pelo olhar daquele que nunca entrara antes na selva escura, úmida, cheia de mosquitos, formigas e outros animais, e o modo como este se insere à vida da floresta a ponto do humano quase desaparecer diante das forças animais e obscuras da selva:

L'unité de la forêt, maintenant, s'imposait; depuis six jours Claude avait renoncé à séparer les êtres des formes, la vie que bouge de la vie qui suinte; une puissante inconnue liait aux arbres les fongosités, faisait grouiller toutes ces choses provisoires sur un sol semblable à l'écume des marais, dans ces bois fumants de commencement du monde. Quel acte humain, ici, avait

${ }^{174}$ IBIDEM - pp. $412-413$. 
un sens? Quelle volonté conservait sa force? Tout se ramifiait, s'ammollisait, s'efforçait de s'accorder à ce monde ignoble et attirant à la foi ${ }^{175}$.

Nessa "inclusão" e imersão no mundo selvagem, Claude vai junto com Perken, Xa (o rapaz contratado para ajudá-los) e Svay (um cambojano contratado pelo delegado francês para requisitar os condutores e também para vigiar Claude e Perken). Logo encontram um templo e Claude começa a caminhar sobre os muros, enfrentando formigas negras, o perigo da queda e de uma gangrena, para verificar se havia estátuas ali, mas nada encontra.

Depois de vários dias, só encontravam ruínas sem importância e a Estrada Real, que tanto prometia, só mostrava vestígios, restos. Mas em uma pequena vila procuradores de madeira falam que entre caminhos cambojanos e uma parte inexplorada do Sião (em uma região moï) ficava o edifício de Ta Mean, com vários baixo-relevos. Quase sem esperança e com medo de nada encontrar, Claude e o grupo continuam e no caminham se deparam com o "espetáculo" de selvagens nômades queimando seus mortos.

O narrador nos mostra os sentimentos que a selva causa em Claude, o pavor e atração que esta provoca nesse homem ainda jovem e mal saído da Europa. Todo o ambiente é sombrio, povoado por animais e ruínas sem importância, por folhas e terras úmidas e podres, por cheiros e sons desconhecidos. Essa floresta tão assustadora a ponto de enlouquecer e anular os homens, despertando neles o corpo, os nervos, se mostra, ao mesmo tempo, atraente e fascinante.

Chegam novamente em um templo e no início Claude nada vê. Mas ao ver o sorriso do guia e de Perken (e após um instante de raiva por vê-los sorrir com o fracasso dele), Claude finalmente percebe o que não vira antes: figuras esculpidas nas pedras e "la joie l'envahit, une reconnaissance sans objet, une allégresse aussitôt suivie d'un attendrissement stupide" ${ }^{176}$.

Seu olhar acompanha as pedras e os desenhos, enquanto Perken vai buscar os instrumentos necessários para arrancar as pedras (Svay, o cambojano contratado pelo instituto francês, ficara no vilarejo, como pedira Perken, para que ele não controlasse as ações deles). No reconhecimento do templo, dos ângulos e pedras, eles acabaram por descobrir duas dançarinas completas esculpidas.

\footnotetext{
${ }^{175}$ IBIDEM - p. 417.

${ }^{176}$ IBIDEM - p. 424.
} 
E então o narrador, pela primeira vez, deixa de acompanhar e narrar tudo pelo olhar de Claude, seus sentimentos e pensamentos, para "adentrar" em um domínio no qual este personagem não teria acesso: no pensamento de Perken. Se até agora este era visto sempre através da perspectiva de Claude e por meio de suas falas, aqui o narrador nos mostra seu pensamento. Mas é só por alguns instantes: após dizer que este pensava nas metralhadoras que fora buscar na Europa e que se encontravam ali, naquela floresta que tão bem conhecia, o narrador volta a descrever os esforços sobrehumanos que Claude e Perken fazem para soltar as pedras do templo. Com a enorme resistência passiva que as pedras ofereciam, ambos se irritam e mostram a raiva na violência com que tentam quebrá-las e separá-las, até que, com as forças físicas e o corpo quase vencidos, conseguem.

Ao carregar as imensas e pesadas pedras para as charretes, ouvem barulho de galhos quebrando, sendo pisados e logo pensam que pode ser Svay que os segue e vigia, mas não encontram ninguém. Voltam a caminhar com as charretes agora cheias até um abrigo - e lá quase todos cedem ao cansaço. Ao acordar, Claude "trouve (...) une des joies les plus complètes qu'il eût connues. L'acharnement qui depuis des mois le poussait furieusement vers une action si incertaine était justifié" ${ }^{177}$. Alegria e justificação de suas ações: as pedras ali ao seu lado simbolizavam a vitória de Claude, um modo de agir diferente, sem buscar o idiota sentimento de "reconhecimento" que a sociedade européia tanto pregava, sem se submeter a normas e modelos, desrespeitando-os mesmo.

Mas basta acordar para saber que Svay e os condutores tinham fugido e levado consigo algumas carroças. Com Claude e Perken só restava Xa e suas 3 carroças carregadas com as pedras. Sem condutores, Perken e Xa vão até um vilarejo vizinho para encontrar ao menos um guia, mas ao voltarem, dizem a Claude que Svay já tinha passado por lá e levado consigo os guias que conheciam o caminho de volta, para o sul. E sem guia e com o Instituto Francês logo sabendo do roubo das pedras, o melhor era ir o mais rápido possível em país dissidente, em meio aos vilarejos dos moïs assim, sairiam do controle do Instituto e ao mesmo tempo iriam em busca de Grabot, sobre quem Claude pergunta e Perken diz sobre sua coragem e isolamento ("il est beaucoup plus séparé du monde que vous et moi parce qu'il n'a pas d'espoir") ${ }^{178}$, de como arrisca sua vida, como mostra um orgulho primitivo em tudo que faz.

${ }^{177}$ IBIDEM - p. 435.
${ }^{178}$ IBIDEM - p. 440. 
Parece-nos que Grabot é Perken e Claude ao extremo: corajosos, mas não a ponto de se picarem voluntariamente por um escorpião porque demonstrara anteriormente repulsão por ele, de se cegarem para se "vingar" de outra pessoa, como Grabot fizera; isolados, deslocados, mas não sem esperança - como era Grabot. Este homem simboliza o extremo da coragem e isolamento que Perken e Claude procuram, e se vão ao seu encontro, não é apenas porque o governo de Sião mandara Perken, mas também para encontrarem o homem que manifesta a perfeição e exacerbação dos sentimentos tão almejados por nossos dois personagens.

O que importa é sua figura do homem lúcido em sua loucura, frio em suas imensas paixões, a do homem que soube negar e fugir dos valores morais e modelos, que soube imprimir, com coragem e raiva, uma cicatriz não só na terra como nele mesmo (como bem mostra sua cegueira e a picada de escorpião que decidira tomar). Homem que enfrenta o mundo, a morte e a si mesmo, Grabot é o deus de Perken e Claude, que passam então a peregrinar em sua busca.

E se até essa segunda parte do livro a narração se assemelha e muito à biografia de Malraux, à sua viagem em busca de templos abandonados e suas riquezas, centrando-se no personagem de Claude, a partir de agora o narrador se afasta dos acontecimentos vividos pelo autor do romance e passa a relatar a procura por Grabot em meio às tribos e países insubmissos, centrando-se mais em Perken e em suas relações com os indígenas e a doença.

Os dois avançam ainda mais na selva, na "sauvagerie avec son odeur de viande" $^{179}$, e em troca de garrafas de álcool, os moïs permitem suas passagens. Mesmo assim obstáculos se põem: lanças de guerra feitas de bambu estão espalhadas por todo lado e, pelo modo como estavam sendo tratados, pela vigilância e desconfiança, Perken pensa que Grabot não poderia ser o único chefe dali - um europeu não agiria dessa maneira típica dos selvagens, a não ser que tenha se transformado totalmente e se tornado um desconhecido aos olhos de Perken.

Nessa noite escura e silenciosa, perigosamente silenciosa, Perken confessa a Claude: "vous savez aussi bien que moi que la vie n'a aucun sens: à vivre seul on n'échappe guère à la préoccupation de son destin... La mort est là, comprenez-vous, comme... comme l'irréfutable preuve de l'absurdité de la vie..." ${ }^{180}$. A morte se mostra

\footnotetext{
${ }^{179}$ IBIDEM - p. 443.

${ }^{180}$ IBIDEM - p. 447.
} 
o tempo todo: na impotência simbólica e real, na velhice, na submissão, na própria condição de homem.

E é contra isso tudo que Perken deseja lutar, contra essa morte que não é só o morrer mas sim o viver submisso - e é por isso que diz que "ce n'est pas pour mourir que je pense à ma mort, c'est pour vivre" ${ }^{181}$. Sua obsessão pela morte não é obsessão por se matar, pela morte física, mas uma obsessão pela própria vida: se a morte é a submissão, é necessário pensar nela o tempo todo para poder negá-la por meio da ação absurda, da potência e da coragem, no desbravamento viril das selvas e no erotismo exagerado. Perken precisa negar essa morte. E para negá-la, é preciso viver, agir negando o tempo e a própria condição humana (que é envelhecer e sentir os efeitos trágicos do tempo).

No dia seguinte, eles retomam a caminhada e chegam na vila stieng, na qual a desconfiança e vigilância continuam. Perken e Claude vêem um moï com um fuzil (o que indica haver um branco ali), que os leva até o chefe da tribo para fazerem um juramento - os brancos oferecem uma jarra de álcool de arroz e com ela o chefe faz o juramento de lealdade, aceitando ambos ali. Além do fuzil, eles vêem um moï com uma roupa branca de europeu, mais um indício de que Grabot devia estar ali.

Mas se por um lado tudo parecia indicar que Grabot ali estava, sua ausência preocupava Perken: "L'absence de Grabot m'embête terriblement. Nous nous engageons, et il ne s'engage pas, à l'égard des Moïs"182. E mesmo com os Moïs aceitando a jarra de álcool de arroz (e sabendo que eles não costumam trair seus juramentos), pensar que Grabot era um dos chefes e que ele não aparecera para o juramento fazia com que Perken temesse a não-validade do juramento, ainda mais quando o chefe responde a ele que na vila não havia nenhum branco.

Um guia os leva até um casebre vazio, na qual ficarão até seguir a viagem em busca de Grabot; mas no caminho Perken pede para Xa perguntar a um escravo qual era a casa do branco. Pergunta de guia para escravo, o escravo acaba por responder que é a palhoça perto das bananeiras. Perken e Claude decidem caminhar até lá, como se estivessem apenas passeando, passando por acaso ao lado do casebre.

Eles entram nessa palhoça sem janelas e fechada por uma porta rudimentar - e nesse ambiente escuro no qual só alguns raios penetravam, algo se movia e chamava a atenção.

${ }^{181}$ IBIDEM - p. 450.

${ }^{182}$ IBIDEM - p. 452. 
Perken avait reculé pour mieux voir en gagnant l'ombre, et Claude le suivait de côté, en crabe, incapable à la fois de rester où il était et de détourner son regard, pour marcher, de la lumière qui pénétrait dans la case comme un bloc de pierre. Mais Perken reculait toujours. Recul terrifié: Claude devinait la crispation de ses doigts qui cherchaient à s'accrocher, la stupeur d'un homme qui chavirait: il ne disait rien, ne bougeait pas. Attaché à la meule, il y avait un esclave. De la barbe sur le visage. Un Blanc? ${ }^{183}$.

Terror e repulsão: eis o que esse escravo branco preso e cego provoca em Perken e Claude. Seria esse escravo Grabot, o homem que mais conseguia se isolar e ter coragem de lutar contra a submissão, a resignação? Teria o ideal de Perken e Claude se reduzido a essa condição tão deplorável de escravo cego e preso, à submissão das submissões? "Aussitôt, les deux Blancs sentirent que ce qu'ils redoutaient le plus était l'approche de cet être. Ni répulsion, ni crainte: une terreur sacrée, l'horreur de l'inhumain que Claude avait connue devant le bûcher"184.

Grabot ali, preso, cego dos dois olhos (e agora não mais por sua vontade, mas por sua submissão), simbolizava o inumano, o espetáculo de tudo que ele negava e de tudo contra o que Perken e Claude lutavam - preso a correntes, mal podia se mover, cego dos dois olhos, de nada adiantaria poder se mover: Grabot mostrava a impotência total, a submissão total - e diante desse espetáculo do inumano, o horror, a raiva e o sagrado se misturam (do mesmo modo que o corpo torturado e morto do alemão Klein, colocado de pé contra uma parede, provocava em Garine em Les Conquérants).

A porta é fechada e Claude percebe que os Moïs estavam em torno da palhoça. Ele reabre a porta e Perken solta as correntes que prendiam Grabot. Os três saem e quase todos os Moïs os seguem, mas recuam, não atacam, esperando pelo chefe, que não estava. Claude pensa que é melhor partir logo, antes que o chefe volte, mas Perken o lembra que sem guia (e eles não o teriam se fugissem) a floresta seria pior que enfrentar os Moïs. Os brancos e Xa ficam em sua palhoça com armas e esperam, observando que os Moïs começam a se armar com lanças, e provavelmente (segundo Grabot), colocariam fogo na palhoça em que estavam.

Enquanto eles esperam, os Moïs plantam lanças de guerra no chão, preparam armadilhas e esperam o chefe, que enfim chega, para saber qual a melhor ação a

${ }^{183}$ IBIDEM - p. 455.
${ }^{184}$ IBIDEM - p. 456. 
realizar. No ambiente de tensão e hostilidade, Perken parece petrificado. Levanta-se, coloca-se na abertura da palhoça, e segurando o revólver, começa a caminhar em direção aos Moïs. "Toute pensée précise était anéantie par ces têtes aux aguets: l'irréductible humiliation de l'homme traqué par sa destinée éclatait. La lutte contre la déchéance se déchaînait en lui ainsi qu'une fureur sexuelle, exaspérée par ce Grabot qui continuait à tourner dans la case comme autour du cadavre de son courage" ${ }^{185}$.

A presença de Grabot, antes tão desejada, agora simboliza tudo o que Perken e Claude não desejam para si - e se este absurdamente pensa em atirar em Grabot para suprimir sua impotência e derrota, Perken reage de uma maneira tão desesperada quanto, tentando, assim, evitar o mesmo destino que Grabot. Sem pensar, sem ver, lança-se em direção aos Moïs, caminha pesada e lentamente, cai, levanta, sente picada das plantas... o chefe Moï pede para ele abandonar o revólver, e ele o deixa cair. Tal como a caminhada de Cristo ao calvário, Perken sente toda a tensão e resistência em seu corpo, cai: "une fois de plus il se trouva planté dans le sol, vaincu par la chair, par les viscères, par tout ce qui peut se révolter contre l'homme" ${ }^{186}$. Diante desses Moïs que não apenas cegam mas também castram os escravos, Perken não sente medo, continua a caminhar e novamente cai, mas agora sobre uma flecha, que machuca seu joelho e o faz sangrar.

Os Moïs o cercam cada vez mais, mas não o agridem. Deixam-no chegar perto do chefe e por meio do guia tradutor, diz a ele que o homem branco cego vale mais de cem jarras (objeto valioso). Enquanto o chefe e guerreiros conversam sobre a proposta, Claude se aproxima de Perken e este oferece mais jarras (uma para cada guerreiro). Os Moïs concordam com a proposta de Perken e permitem que ele, Claude e Xa partam para pegarem as jarras e as entregarem em troca de Grabot.

Um guia os acompanha para mostrar e marcar o lugar onde será feita a troca. Os três vão com as charretes e o ferimento de Perken o domina cada vez mais. Param em um bangalô e descobrem que lá havia dois médicos: um indígena e um médico inglês, que vai vê-lo.

Ao examinar seu joelho, Perken diz que os povos selvagens nunca envenenam as pontas de suas flechas, mas o médico diz que "un homme s'empoisonne très bien tout seul" ${ }^{187}$. Há cinco dias com a ferida aberta, com febre, o médico dá a condenação

\footnotetext{
${ }^{185}$ IBIDEM - p. 466.

${ }^{186}$ IBIDEM - p. 467.

${ }^{187}$ IBIDEM - p. 480.
} 
a Perken: a única solução seria amputar a perna mas não dará tempo de chegar a uma cidade. Só resta fumar ópio e diminuir a dor. E embora Perken diga que há um velho contato entre ele e a morte, não aceita o diagnóstico do médico, tenta achar outras soluções (corte de bisturi, por exemplo) e discute com o médico, dizendo já ter sido picado antes.

O chefe do posto chega e anota o que acontecera, pensando que o governo de Sião dará as jarras, pegará Grabot e depois da troca aproveitará para reprimir os Moïs e ocupar essa região dissidente, permitindo que as linhas de ferro sejam construídas mais facilmente e provocando o pânico na região (o que realmente ocorre).

E se o médico indígena era esperado para mostrar que o médico inglês errara, isso não ocorre. Ele repete as mesmas palavras do inglês e Perken o manda embora: a condenação está feita, Perken irá morrer.

Il était si étranger à cette mort aux aguets en lui qu'il se sentait de nouveau en face d'un combat: mais le regard de Claude le rejeta dans son corps. Il y avait en ce regard une complicité intense où se heurtait la poignante fraternité du courage et la compassion, l'union animale des êtres devant la chair condamnée; Perken, bien qu'il s'attachât à lui plus qu'il ne s'était attaché à aucun être, sentait sa mort comme si elle fût venue de lui. L'affirmation impérieuse était moins dans les paroles des médecins que dans les paupières que Claude venait instinctivement d'abaisser ${ }^{188}$.

Essa amizade e fraternidade viril que ligava Perken a Claude (assim como ligava Garine ao narrador em Les Conquérants) é também quem mais simboliza a morte: o olhar cúmplice de Claude devolve a Perken a carne, o corpo que ele tanto desejava esquecer. E mais que as palavras, é o olhar, o olhar do homem a quem tanto se sentia ligado, que melhor e mais dolorosamente revelava a condição humana de Perken.

O narrador descreve agora Perken em seu ato sexual, no erotismo sempre desejado com violência, como símbolo contra a impotência metafórica e como ato contra a impotência real - mas que agora, próximo da morte, revela-se diferente, como representação máxima da solidão, da separação: "il ferma lui aussi les yeux, se rejeta sur lui-même comme sur un poison, ivre d'anéantir, à force de violence, ce visage

${ }^{188}$ IBIDEM - p. 484. 
anonyme qui le chassait vers la mort" ${ }^{189}$. Agora, ferido e condenado, Perken vê até mesmo no erotismo e no sexo sua condenação: jamais ele conhecerá as sensações dessa mulher, do outro - simbolizando nesse ato a solidão à qual está condenado, à morte.

Perken, mesmo doente, queria ajudar sua região contra os Moïs, que agora atacavam outras tribos. Mas até mesmo o governo do Sião já desrespeitava o acordo que fizera com Perken e começava a avançar sobre sua região, fazendo com que este dissesse: "Pour ceux-là aussi, je suis déjà mort..."190 e o narrador afirma que "malgré la douleur, il se sentait furieusement vivant contre cette affirmation de sa déchéance. De nouveau combattre. Et pourtant, tout ce qu'il avait fait était devant lui comme son propre cadavre. Avant une semaine la colonne pouvait être chez lui, et sa vie n'aurait été qu'une attente vaine"191.

Perken oscila entre os momentos de abandono e de raiva, sente-se morto em um segundo e no outro reúne forças e ódio para continuar a combater, a lutar não só contra os Moïs que fugindo atacam outras tribos mas também e agora sobretudo contra o governo siamês e a construção da estrada de ferro - e desse modo, tentar fazer com que sua vida toda não se resuma na dura e lamentável descrição de uma "espera vã". Se parte de sua vida fora dedicada a dar poder a algumas tribos do Laos, ele não poderia ver, já no fim de sua vida, tudo se arruinar.

Ele decide então partir e ir a sua região. Logo vêem a montanha atrás da qual o território de Perken se encontrava ${ }^{192}$, e este ainda tem esperança de ajudá-los: "Il faudrait que ma mort au moins les oblige à être libres"193. Oscilando entre o reconhecimento de sua morte e a raiva e vontade de agir, Perken ainda pensa ser capaz de fazer de sua morte uma utilidade, de ainda ajudar a sua região a não se submeter ao governo siamês.

Se sua vida já estava condenada e se ele não tinha filhos para "doar sua esperança", era à sua tribo que a doava (como falara a Claude ainda no início do romance). Para que sua vida não caísse na total decadência e submissão, como a de Grabot, era necessário que sua tribo se salvasse da subordinação, permanecesse livre. Só assim Perken não veria em toda sua vida uma "espera vã".

\footnotetext{
${ }^{189}$ IBIDEM - p. 487.

${ }^{190}$ IBIDEM - p. 491.

${ }^{191}$ IBIDEM - pp. $491-492$.

192 e nesse momento, Claude já pensava na estrada de ferro que passava ali perto, e que, quando Perken moresse, ele iria até ela e estaria a salvo dos Moïs.

${ }^{193}$ IBIDEM - p. 502.
} 
Mas nesses momentos de absurda lucidez, em que, quase imobilizado por sua dor e infecção ainda deseja, com calma e ira, vencer, resistir, Claude não mais the aparece do mesmo modo. Agora Claude não era mais visto como o amigo, como aquele que o compreendia e o aceitava sem nada questionar - com a morte cada vez mais física e perto, com seu corpo cada vez mais pesado e menos seu, Claude agora se tornava o outro, aquele que ia viver e não mais podia se identificar com Perken: "à côté de lui, Claude qui allait vivre, qui croyait à la vie comme d'autres croient que les bourreaux qui vous torturent sont des hommes: haïssable. Seul. Seul avec la fièvre qui le parcourait de la tête au genou, et cette chose fidèle posée sur sa cuisse: sa main"194.

Claude vê que Perken sofre e que o sangue começa a escorrer entre seus dentes - e o sofrimento, ao invés de levar Perken à morte, o defendia dela: enquanto sofresse, se protegeria da morte. Mas o amigo já lhe aparecia com um rosto que não era humano, com um rosto que se encontrava face a face com a vanidade de ser homem, e que ainda disse: "il n'y a pas...de mort... Il y a seulement... moi...moi...qui vais mourir..."195.

Diante dessa agonia, desse decreto de morte - ou melhor, de Perken afirmando que não há morte mas sim ele que vai morrer, Claude se angustia, deseja mostrar e exprimir por gestos, olhares e palavras "cette fraternité désespérée qui le jetait hors de lui-même! Il l'étreignit aux épaules. Perken regardait ce témoin, étranger comme un être d'un autre monde" 196.

A fraternidade viril aparece no final de La Voie Royale, assim como em Les Conquérants, e é justamente nesse instante de máxima solidão e presença da morte que a amizade se torna mais intensa.

Em Les Conquérants, Garine abraça o narrador e neste gesto de fraternidade e força torna-se ainda mais forte a morte e o silêncio de Garine - e aqui, em La Voie Royale, o narrador nos mostra as tentativas desesperadas e vãs de Claude para expressar sua ligação com esse homem que tanto amava, enquanto este olhava esse testemunho já como um ser de outro mundo.

As manifestações de afeto e amizade, tão fortes no final desses dois primeiros livros, vêm junto com a sensação de vanidade e solidão - a morte de Garine e de

\footnotetext{
${ }^{194}$ IBIDEM - p. 503.

195 IBIDEM - p. 506.

${ }^{196}$ IBIDEM - p. 506.
} 
Perken (a deste mais presente e próxima que a do outro) transformam a amizade em um sentimento nobre e ao mesmo tempo vão, bonito e desesperado, comunhão e separação.

$\mathrm{Na}$ tentativa de vencerem o absurdo de toda vida e marcarem uma cicatriz na terra, Garine e Perken se isolam da sociedade. A amizade, a união com o outro se torna, porém, mais forte: à medida que convivem com o narrador e Claude, unem-se a eles e chegam a ter momentos de profunda fraternidade. Mas com os desejos fracassados, com a impossibilidade de vencer essa luta contra o destino e a morte, com esta invadindo o corpo e ser de ambos, a solidão se torna mais pungente - se a amizade se torna cada vez mais forte, ela não se mostra capaz, porém, de romper esse último instante de confronto do homem que vai morrer com o seu destino. Nem Claude nem o narrador de Les Conquérants conseguem tirar Perken e Garine da mais absoluta, extrema e absurda solidão em face da morte próxima.

La Voie Royale mostra, de um modo muito mais claro e direto (e talvez por isso, de modo menos literário), o confronto eterno do homem contra seu destino, contra as forças absurdas que nos governam; confronto esse que só é possível enfrentar na extrema solidão. Claude e Perken, da mesma maneira que o narrador e Garine em Les Conquérants, exprimem, em um momento de solidão, uma fraternidade imensa, a qual não é, porém, suficiente para tirá-los desse solipsismo.

Claude, Perken e Grabot realizam a mesma luta contra os valores burgueses de "reconhecimento" e "passividade" e em seus atos desejam se mostrar donos de si, vencer o que é invencível - a Morte. É sobre a condição inumana da realidade humana que o livro trata, do mesmo modo que ocorria em Les Conquérants, mas agora sem que a concretude histórica apareça com muito peso. "La Voie Royale sera la mise en scène, dans un décor de jungle tropicale, de la grande tragédie de l'être humain: créature mortelle soumise au Destin, c'est en affrontant sa propre mort que l'homme se reconnaît" 197 .

E se Perken luta contra o governo de Sião, se quer dar armas para os selvagens enfrentarem o governo, não é porque se preocupa com eles e deseja acabar com a colonização. É porque vê nesse luta um modo de enfrentar o destino, e nem mesmo sua morte é capaz de dar um sentido político e concreto a essa luta - ao contrário;

${ }^{197}$ LANGLOIS. Notice In MALRAUX. Oeuvres Complètes - p. 1127. 
assim como vimos em Les Conquérants, ela torna tudo indiferente. Perken é um jogador, e joga não o destino dos moïs, mas sua vida contra a morte.

Do mesmo modo que Garine se diz um jogador, Perken também o diz, e ainda revela a Claude que preferiu jogar com vinte tribos do que com uma criança. Nesse jogo de baralho contra a Morte, Perken escolhe suas cartas (as vinte tribos), pensando ter mais chances de ganhar com elas. Mas por que vinte tribos possibilitam mais a vitória que um filho? Isso nos leva a pensar que Malraux talvez tenha razão ao afirmar que se Garine escolheu ficar ao lado dos revolucionários e até arriscou sua vida é porque, de alguma maneira, se importava com eles, estava ligado à sorte da Revolução. Aqui poderíamos dizer o mesmo de Perken: se ele escolheu defender as tribos e não ter um filho é porque ele se interessa pela submissão à qual as tribos estavam lançadas.

Mas se essa concepção faz sentido, não encontramos, porém, em nenhum dos dois romances, tanto no conteúdo quanto na forma, elementos que revelem o sentido dessa escolha. Ao contrário: tudo que encontramos (tanto na fala desses personagens quanto na forma de narrar a relação entre o indivíduo e a história) nos revela uma indiferença de Perken e Garine às causas e conseqüências de suas ações. Os revolucionários e as tribos parecem ser apenas as cartas com que o jogo é jogado, e nem podemos dizer que elas importam pelo valor escrito nelas (se forem altas, possibilitam ganhar o jogo), já que esse jogo é, de antemão, impossível de se ganhar.

Mesmo que eles escolham a Revolução e as tribos, e não valores burgueses e filhos, não se pode dizer que essa escolha tem, para os personagens, mais sentido que outras escolhas, já que o jogo está perdido desde o início. A morte infalivelmente chega (não só a morte biológica mas também a morte do não sentir-se dono de seus atos), é uma realidade virtual que, ao se atualizar, necessariamente retira retroativamente todo o valor a uma ação que só no indivíduo encontrava seus alicerces $^{198}$.

E é o enfrentamento com e contra a Morte que interessa a Perken, Claude e Grabot. Os três desejam, de algum modo, fugir da submissão e garantir uma eternidade - se não há como fugir da morte biológica, é preciso ao menos fugir da morte de todos os feitos, da morte da vida de cada um. Grabot, por meio de sua lúcida loucura, espalha "cicatrizes" por onde passa (seja em si mesmo, seja na memória dos

${ }^{198}$ Cf. GOLDMANN - Sociologia do romance. 
que o viram e nas terras em que passou); Perken invade a selva e conquista tribos insubmissas, e Claude também entra na floresta para descobrir baixo-relevos de antigos templos.

Os três penetram em uma floresta no Oriente, no desconhecido, para mostrar coragem e isolamento em relação aos valores ocidentais, para ali, na exigência mais extrema de suas forças, conseguirem enfrentar de modo mais intenso o absurdo, humano e certo destino, a morte.

E se o livro nos revela momentos de vitória (afinal, Grabot vai até os moïs, Perken consegue encontrar Grabot e Claude encontra seus baixo-relevos), não é essa a sensação que o leitor tem, nem mesmo durante esses breves momentos. No instante em que encontram as bailarinas esculpidas, há tanto esforço físico que a exaustão não permite sentir a alegria; e logo depois, quando o êxito poderia ser comemorado, é a notícia da fuga de Svay e dos condutores que chega.

O mesmo se dá quando Perken e Claude finalmente encontram Grabot: esse momento de "vitória" é acompanhado de tanto terror e perigo que não nos lembramos que esse ato era uma conquista. As aventuras, mesmo quando conquistadas, parecem perdas. É por isso que Langlois diz que

un certain nombre de victoires sont remportées, car Claude Vannec découvre les statues qu'il espérait et Perken retrouve Grabot. Mais ce sont là des victoires éphémères. Très vraisemblablement, Vannec ne rejoindra pas la civilisation avec son butin et Grabot retrouvé n'est plus qu'une épave humaine pour qui Perken doit sacrifier jusqu'à sa vie. Si Claude réussit à vaincre son aversion profonde pour les myriades d'insectes de la forêt tropicale et si Perken ose envisager sa vieilesse et l'une de ses marques qu'il redoute le plus - l'impuissance sexuelle-, ces victoires de la volonté sont de courte durée: Perken meurt sans défense contre le Destin et Claude est replongé dans la solitude avec ses cauchemars ${ }^{199}$.

Assim como em Les Conquérants, há ao mesmo tempo vitória e fracasso: Garine conseguira aprovar o decreto, a Revolução ganha mas ele vai morrer; Perken encontra Grabot, acha meios de conseguir dinheiro para comprar as metralhadoras e armar suas tribos, mas morre; e por fim, Claude consegue achar os templos abandonados e bailarinas esculpidas, o que lhe daria muito dinheiro, mas vê aquele

${ }^{199}$ MALRAUX. Oeuvres Complètes - p. 1134. 
homem que era seu próprio futuro (Perken) morrer em sua frente sem nem ao menos conseguir expressar o quanto estava ligado a ele, sem nem mesmo saber se conseguirá levar os baixo-relevos até a Europa.

De todo modo, é Claude quem menos perde: se viu a submissão do homem que soube levar aos extremos seus desejos (Grabot, encontrado cego, escravo, castrado, sem forças) e se viu Perken em sua dor diante do joelho infeccionado e diante da morte, que logo ocorre; ele se diferencia dos dois justamente porque não morreu e não tem doença alguma ${ }^{200}$. Claude é, junto com o narrador do primeiro livro, um personagem que não adoece nem morre. É o único que, de certo modo, vence, e talvez porque "si, finalement, il 'perd' ses statues, du moins leur découverte lui permettre de confirmer certaines de ses théories sur l'art, et tout particulièrement celleci qui annonce un autre Malraux: seuls l'art et l'artiste peuvent échapper à la mort que le Destin impose à tout, et même aux civilisations" ${ }^{201}$.

Talvez seja excessivo dizer isso, mas ao menos Claude é o único que sobrevive e o único que se interessa pela arte. A arte, assim como a ação, revela-se para Claude como meios do homem enfrentar e negar sua morte, eternizando-se nessas criações.

E não é só o discurso sobre a arte que Claude faz mas também seus atos (e também os de Perken e de Grabot) revelam que só há uma maneira de enfrentar a Morte: fugindo dessa imagem desvelada no mundo, negando-os (o mundo e a desordem) abstratamente não no mundo, na desordem mas em um outro mundo criado, imaginado, no qual seríamos totalmente donos de nossas ações, já que a ordem e a lógica prevaleceriam - e ao negar o real em direção à transcendência, a Morte também seria, de certa forma, negada, substituída pela Eternidade (que os museus e as memórias não cessariam de revelar por meio da metamorfose).

Aos personagens de Malraux parece não haver outra saída senão o próprio sair, fugir, abandonar. Diante da falta de sentido no mundo que a morte de Deus provocou, não podemos mais tentar encontrar um sentido nele e/ou viver nele sem sentido algum - os personagens de Malraux substituem Deus pelo Eterno, e suas ações e artes desvelam não a existência concreta nesse chão cheio de sangue e lama mas sim a luta vã, incessante e perdida de início contra o absurdo da morte e as aspirações ao novo Deus - à eternidade por meio da metamorfose.

\footnotetext{
${ }^{200}$ Até agora, muitos dos heróis deMalraux são doentes.

${ }^{201}$ LANGLOIS, Notice In MALRAUX. Oeuvres Complètes - p. 1139.
} 
No próximo livro ( $\mathrm{La}$ Condition Humaine) no entanto, a questão da fraternidade se torna muito mais forte, a ponto de muitos verem aqui a superação do solipsismo e das questões metafísicas. Vejamos se isso realmente ocorre.

\section{C) La Condition Humaine}

O romance La Condition Humaine, pelo cenário urbano (Xangai) e pelo próprio enredo (as disputas entre o Kuomintang e o PC chinês), remete-nos sempre a Les Conquérants e quase nunca a La Voie Royale. Pelo conteúdo nitidamente histórico do primeiro e do terceiro livro, La voie Royale acaba por se mostrar separado, isolado, livro menor - quando, na verdade, ele mostra os mesmos sintomas e angústias do homem contemporâneo, com as mesmas questões metafísicas diante do não-sentido da vida; sem, no entanto, situá-las em meio a eventos revolucionários.

La Condition Humaine, publicado em 1933, relata uma revolta real que deixa de ter tanto valor diante das questões perante o fracasso e a morte. Pretendemos mostrar que, se a história retorna com força nesse livro, ela é retomada às vezes da mesma maneira como no primeiro e segundo livro - como símbolo de uma luta maior e mais importante, e às vezes de um modo muito diverso, com os personagens realmente inseridos nela e lutando por modificações concretas.

E enquanto Les Conquérants mostrava a greve geral decretada em Cantão no ano de 1925, agora são os acontecimentos de 1927, centrados em Xangai mas realizados pelos mesmos autores (o Kuomintang, o Partido Comunista Chinês), que são narrados em La Condition Humaine. E se no primeiro livro Tchang Kaï-cheg estava do lado do PC, agora, dois anos depois, ele domina as tropas nacionais e entra em conflito com o PC chinês, fazendo assim, com que a ala direita do Kuomintang assuma o poder e tenha o controle das revoltas feitas pelo PC.

Se os acontecimentos em La Condition Humaine são a continuação dos já vistos em Les Conquérants, o modo como Malraux narra esses acontecimentos nos remete a La Voie Royale - enquanto Les Conquérants era narrado em primeira pessoa, com o narrador-personagem sempre relatando o que percebia, sempre com uma perspectiva adotada, e sempra a mesma perspectiva (desse francês que vai a Cantão para ajudar a fazer trabalhos burocráticos e ganhar dinheiro), em La Condition Humaine esse relato em primeira pessoa é abandonado; o narrador relata os 
acontecimentos, nos conta a vida dos personagens e seus pensamentos, tornando a narração mais complexa e fragmentada: se em Les Conquérants o narrador em primeira pessoa nos permitia acompanhar os acontecimentos apenas com seu olhar (cúmplice dos revoltosos), agora há a multiplicação dos olhares, das perspectivas vemos o militante pelo olhar do francês e o francês pelo olhar do militante.

O livro inicia em 21/03/1927 à meia-noite e meia, com o personagem Tchen em meio a uma ação. Não temos, como nos livros anteriores, uma "apresentação" dos personagens e acontecimentos - se tanto em Les Conquérants quanto em La Voie Royale iniciávamos o romance em meio a um navio que ia em direção aos acontecimentos, em uma viagem na qual éramos apresentados aos principais personagens e às questões do livro, em La Condition Humaine somos "jogados" diretamente em meio a uma noite em que Tchen, de quem nada sabemos, mata um homem que também não conhecemos.

O narrador acompanha Tchen em sua angústia carnal diante de um corpo que dormia por trás de um véu, que deixava ver apenas seu pé vivo na escuridão quase que total do quarto, iluminado por luzes que vêm de outra construção. Dentro do quarto parece não haver movimento, vida nem tempo: todos os sinais de vida parecem vir de fora, da rua. Ali é o silêncio do corpo que dorme e que logo estará morto que domina, e também o corpo de Tchen em náusea, mostrando a seu dono que ele não era o combatente mas sim um sacrificador. Segura o punhal com o braço direito e espera: "Il éleva légèrement le bras droit, stupéfait du silence qui continuait à l'entourer, comme si son geste eût dû déclencher quelque chute. Mais non, il ne se passait rien: c'était toujours à lui d'agir"202.

Não adiantava esperar, era preciso agir. Era preciso ver a carne, sua resistência, e para isso, sem pensar, enfia o punhal em seu próprio braço esquerdo e a dor que sente sem nem mesmo lembrar que se trata de um braço seu o faz sair dessa atmosfera de loucura e espera: "un seul geste, et l'homme serait mort. Le tuer n'était rien: c'était le toucher qui était impossible"203.

O que angustia e nauseia Tchen não é o assassinato, a morte, mas tocar esse corpo imóvel, como que anunciando o que logo seria: um cadáver. É a carne que exaspera nosso personagem, é atravessá-la com o punhal no lugar e ângulo corretos

\footnotetext{
${ }^{202}$ MALRAUX. "La Condition Humaine" In Oeuvres Romanèsques - p. 512.

${ }^{203}$ IBIDEM - p. 512.
} 
que o obceca. E diante de um movimento do corpo, que mostra assim sua vida e vulnerabilidade, Tchen age rápido e mata esse homem, restando, depois, imóvel, ainda contemplando esse corpo agora tão pesado: "à travers l'arme, son bras raidi, son épaule douloureuse, un courant d'angoisse s'établissait entre le corps et lui jusqu'au fond de sa poitrine, jusqu'à son coeur convulsif, seule chose qui bougeât dans la pièce. Il était absolument immobile; le sang qui continuait à couler de son bras gauche lui semblait celui de l'homme couché; sans que rien de nouveau fût survenu, il eut soudain la certitude que cet homme était mort" ${ }^{204}$.

E no silêncio e embriaguez que tomam conta de Tchen, seu corpo treme, não por medo, mas por solidão: "il était seul avec la mort, seul dans un lieu sans homme, mollement écrasé à la fois par l'horreur et par le goût du sang"205. Seu gesto, atravessar a carne do outro com um punhal, nesse quarto agora ainda mais silencioso e sem vida, jogava Tchen na mais absoluta solidão, na solidão diante da morte, do sangue que o horrorizava e o atraía. A partir desse momento em que a morte se mostrava ali, por vontade e ato de Tchen, este tremia de solidão e se sentia incapaz de voltar ao mundo dos homens.

Mas eis que uma sombra surge e assusta Tchen - o gato que ali aparecera o faz sair das meditações e se encontrar em face da cidade de Xangai, em face à vida, ao barulho da sirene, em meio aos homens que não matam. Todas essas vidas e seus símbolos pareciam rejeitar a vida de Tchen, condenando-o. Não é, porém, a condenação dos outros homens (dos que não matam) que o oprime, mas essa morte que se retirava mas permanecia colada à superfície de seu corpo. É essa angústia perante a morte que adere ao corpo daquele que a viu em face de si, a provocou e a causou, que o impede de voltar à vida de antes.

A sirene que ecoa acordando os funcionários das fábricas de arma acorda também Tchen e o faz pensar no quanto seu ato ajudará as tropas revolucionárias a se insurgirem e tomarem Xangai. Esse homem morto acabara de negociar armas com o governo, e com sua morte e com o papel que indicava a venda das armas, as tropas poderiam ficar com as armas. Tchen procura então o documento e quando o acha sai correndo do quarto, compra uma garrafa de água, como que para se purificar do sangue derramado, e chama um táxi.

\footnotetext{
${ }^{204}$ IBIDEM - p. 513.

${ }^{205}$ IBIDEM - p. 514.
} 
À uma da manhã, entra na cidade chinesa (havia a concessão francesa, na qual só com autorização se podia andar após um horário, e para a qual Tchen tinha um passaporte falso de eletricista) e "il fallait revenir parmi les hommes..." ${ }^{206}$, era preciso entrar naquela loja na qual quatro camaradas se encontravam e o esperavam, era preciso voltar ao mundo da vida e da insurreição, da tomada de Xangai pela tropa revolucionária, à qual ele pertencia.

Lou You-shuen, Hemmelrich, Katow e Kyo Gisors vêem Tchen entrar na loja de discos e o olham com ansiedade. Tchen pensa primeiro na distância que agora o separa deles: "Il pouvait renseigner ces hommes, mais il ne pourrait jamais s'expliquer. La résistance du corps au couteau l'obsédait" ${ }^{207}$. É uma distância marcada pela incompreensão e também pela superioridade. Mas ele nada fala a seus companheiros, apenas diz um "aqui está" e entrega o documento a Kyo, que ao lê-lo vê que há um problema a mais: embora as armas já tivessem sido negociadas, elas seriam pagas no momento da transação - o que complicaria a retirada das armas.

Tchen continuava a se sentir solitário, e nem com Katow, que lhe perguntara se tudo correra bem e que também sabia o que era a morte, se identificava. Em silêncio, observava o movimento da luz para não pensar e se fala, é só para dizer a Kyo que desejava ver o pai deste naquela noite, mesmo sabendo que as tropas revolucionárias de Tchang Kaï-chek chegariam no dia seguinte nas últimas estações da estrada de ferro, determinando, assim, o início da insurreição em Xangai.

Tchen desejava ser compreendido, e para isso sempre se voltava a Gisors, ao pai de Kyo, e este, embora fosse um dos organizadores da Insurreição, não mataria jamais, exceto em combate. Dentre os quatro, só Katow estava mais perto de Tchen, pois já matara na Rússia e fora preso. Mas nem ele era capaz de compreendê-lo, apenas Gisors, com sua velhice e sabedoria, era.

Sem poder dividir seus sentimentos com ninguém, Tchen sai. E o narrador continua na loja de discos com Kyo, Katow, Hemmelrich e Lou You-shen. Mas antes de narrarmos os outros acontecimentos, demoremo-nos um pouco mais no modo como Tchen nos foi apresentado - o que faz com que Roberto Schwarz analise, em um breve e ótimo artigo, algumas questões que já havíamos indicado acerca de Les Conquérants (a respeito do romance histórico no qual a história é submetida à metafísica) e que continua em La condition Humaine.

\footnotetext{
${ }^{206}$ IBIDEM - p. 517.

${ }^{207}$ IBIDEM - p. 517.
} 
Em primeiro lugar, Schwarz assemelha o modo de narrar com o modo do jornalismo, de uma reportagem, mas se neste caso esse modo se dá pela precariedade e fragmentação do ocorrido, no romance trata-se de uma escolha do autor. Em La condition Humaine, "reconhecemos neste mundo incompleto os aspectos informais da visão do repórter. A precariedade do jornalista está transformada, entretanto, na escolha do romancista" ${ }^{208}$.

Não há, no romance, mesmo quando ele trata de acontecimentos que realmente ocorreram, uma realidade externa que faça contrapeso ao cunho inacabado da reportagem (as siglas, recorrência a acontecimentos anteriores sem explicá-los, datas e horários que pressupõem conhecimento do leitor), e isso faz com que a falta provisória de sentido (que não é dado pelo repórter mas é depois construída pelo leitor da reportagem) torne-se uma falta eterna de sentido: há monotonia do destino e fracasso por condição metafísica.

E é isso que se pode ver nessa primeira cena relatada por nós de La Condition Humaine, na cena em que Tchen encontra-se diante do corpo que vai matar, do alto do quarto escuro e quieto, e na cena em que ele volta às ruas, ao chão da história, no momento em que sai de seus pensamentos diante da Morte e se joga em direção aos carros, aos homens, à vida.

Schwarz considera ótima a cena de Tchen diante do corpo e da morte: há descrição lenta e tensa, obsessão e fascinação pelos objetos, que se mostram na forma de vertigem, tudo com técnicas semelhantes à do cinema. Mas ele detecta um problema no momento em que Tchen sai à rua:

Quando volta e desce de encontro ao mundo histórico, impõe-se ao livro a opção entre os dois pontos de vista, dos quais um deverá julgar o outro. Escolhesse mergulhar Tchen na História, e sua aventura apareceria como um caso limite, expressão extrema de uma situação peculiar (...) A experiência de Tchen, no alto da torre, seria um momento histórico. O romance, entretanto, escolhe a solução oposta: a experiência subjetiva de Tchen é tomada por absoluta, e proposta como critério da História. $\mathrm{O}$ barulho do mundo torna-se movimento vão quando visto pelo único prisma válido: a consciência é fraca e seu destino é a morte. Esta posição destrói a multiplicidade e reduz a História a uma ilusão ${ }^{209}$,

\footnotetext{
${ }^{208}$ SCHWARZ. "Existencialismo e romance histórico" In A sereia e o desconfiado - p. 100.

${ }^{209}$ IBIDEM - p. 104.
} 
fazendo com que o romance se torne esquemático, sem variedade: "estabelecido o esquematismo, o romance perde a qualidade extraordinariamente inventiva e reveladora que a sua primeira cena anunciava. Torna-se meramente confirmativa" $^{210}$.

Se a História parece surgir com força, o modo como Malraux a narra a relega a um segundo plano, faz dela cenário de questões mais urgentes e importantes - a questão metafísica perante a falta de sentido da vida e perante a morte. A ação histórica dos personagens parece não inseri-los historicamente, pelo contrário, isola-os ainda mais nessa luta vã e solitária contra o absurdo absoluto.

Tchen, ao voltar para a rua e ao encontrar seus companheiros na loja de discos, não consegue inserir sua ação nos acontecimentos da insurreição - sente-se solitário e não se identifica com mais ninguém, nem mesmo com aquele que também já matara. A experiência solitária de Tchen não é compartilhada: ela continua ainda mais solitária e com isso, torna-se absoluta.

E como a história poderia se mostrar múltipla e forte se a ação se dá "no alto da torre", num quarto silencioso e escuro em que nada parece viver, e se ao descer para as ruas ela não consegue se integrar aos acontecimentos? Assim como a morte parece se retirar mas fica grudada ao corpo de Tchen, a ação solitária e absoluta não desaparece quando esse se encontra com os companheiros; ao contrário, torna-se mais forte e visível na incompreensão e solidão nas quais Tchen mergulha.

Como bem diz Schwarz, a história tão presente em La Condition Humaine (e podemos dizer também em Les Conquérants) é uma ilusão, é vã diante da consciência da morte. Assim, se a história infesta os romances, não é para se fazer presente, mas para se mostrar como ilusão, para se colocar à mercê indiferente das questões metafísicas. A história não aparece em si mesma, nem se mostra como o único lugar no qual as questões metafísicas podem se desenrolar (o que faria com que ela se tornasse essencial); ela parece ser apenas o símbolo da condição humana, da luta dos homens contra o destino absurdo de todos (e é por isso que os personagens sempre agem mas conseguem se manter indiferentes em relação à ação e a suas conseqüências históricas - sempre ligados a questões históricas, sempre se mostram, porém, indiferentes a elas).

${ }^{210}$ IBIDEM - p. 105. 
É por tudo isso que podemos dizer, junto com Schwarz, que "o romance de Malraux oscila, pois, entre o relato histórico interessante, mas jornalístico, e a descrição de experiências de impotência humana, que tendem, no limite, a tornar-se mera exemplificação metafísica; as duas fraquezas são complementares"211 - o que é válido tanto para La Condition Humaine quanto para Les Conquérants (e se é certo que La Voie Royale não apresenta teor histórico igual a esses outros dois livros, é certo que esse romance também revela o que é mais fundamental nos outros livros: a descrição de experiências da impotência humana).

Mas, como bem diz Schwarz em relação à La Condition Humaine, há cenas (como a de Tchen no quarto ao matar o homem) que conseguem fugir ao mesmo tempo do mero jornalismo e da descrição monótona e metafísica da impotência humana (e essas cenas justificam, por si só, a beleza e interesse do livro): "De entremeio aparece a luta pelo sentido, a experiência concreta que não se desfaz em esquemas nem sofre do linguajar cansado da reportagem, no qual não se retém a marca do acontecimento, logo perdido na generalidade do vocábulo convencional" ${ }^{212}$.

Mas voltemos agora à loja de discos onde tínhamos deixado Kyo, Katow, Hemmelrich e Lou.

Depois da saída de Tchen, o narrador nos fala um pouco de Katow (russo, refugiado na Suíça) e nos faz ouvir falsos discos de idiomas para dar instruções da insurreição por meio de um código. Kyo acha que o disco foi bem gravado mas não mais reconhece sua voz nele, ao que Lou (o único realmente chinês entre eles) explica que é raro alguém reconhecer sua própria voz, já que não temos o costume de nos ouvirmos. Enquanto conversam e ouvem os discos, uma criança grita no andar de cima - e quando Kyo diz ser necessário alguns europeus para tratar da questão das armas, Hemmelrich, o dono da loja, fala com raiva que a criança já respondera por ele. Kyo e Katow começam então a discutir sobre as armas e saem da casa de Hemmelrich, que se divide entre o sentimento de estar preso por causa da criança e a vontade de ajudar.

Katow e Kyo andam pela vila chinesa e o segundo pensava nos comitês que preparava para a insurreição, encarregado pelo Partido Comunista Chinês, e no quanto essas ruas desertas escondiam grupos de combate prontos para atacar. Ambos param e

\footnotetext{
${ }^{211}$ IBIDEM - p. 101.

${ }^{212}$ IBIDEM - p. 101.
} 
entram em uma boutique para obter informações sobre as tropas revolucionárias comandadas por Tchang Kaï-chek, e um homem lhes diz que elas devem chegar naquela noite ou no dia seguinte na última estação antes de Xangai. Os dois saem e vão em busca de homens (Katow) e de um intermediário (Kyo) para pegarem as armas no navio antes das 8 da manhã.

Kyo entra na área da concessão francesa e vai até o Black Cat, um bar, onde encontra o homem que estava a procurar: o barão de Clappique, um homem que tinha contato com toda a cidade de Xangai, e que conversava com uma russa e uma mestiça filipina conversas engraçadas, burlescas, dizendo que o ruim é que não há mais fantasia no mundo e que ele era um homem que sabia cultivá-la: "Vous voyez ma tête? Voilà où mènent vingt ans de fantasie héréditaire. Ça ressemble à la syphilis. Pas un mot!"213. Esse francês falava de suas fantasias a essas duas mulheres enquanto Kyo o aguardava em outra mesa, e quando ele sai, Kyo o encontra no corredor.

Kyo conta a Clappique sobre o navio carregado de armas e inventa a história de que tem um comprador a 35 dólares, enquanto o governo queria pagar 30, e que ainda dará 5 dólares de comissão a Clappique, desde que ele consiga arrumar com amigos a certeza de que não serão pegos pela polícia. Clappique pega o contrato e promete arrumar tudo para Kyo, que lhe dá dinheiro para o táxi até o porto, e diz esperar em sua casa pela resposta.

E enquanto Kyo conversava com Clappique, Katow visita uma organização de combate comunista para reunir 12 homens para a transação das armas no navio, e onde fica a conversar sobre as armas que têm (que são ainda poucas - um a cada dois não tem arma) e sobre o medo dos combatentes. O chinês líder dessa organização diz que todos usarão bem as armas, a menos que eles usem tanques contra os insurgentes, ao que Katow tenta animá-lo ("basta usar granadas, nós viremos com força especial para ajudá-los") sem sucesso, mesmo com os chineses confiando nele.

Katow reencontra Kyo e ambos combinam o ataque ao navio (tendo sabido antes, numa central do Kuomitang, que as tropas já estavam em Tcheng-tcheou última estação de trem antes de Xangai) e que uma greve geral tinha sido decretada para o meio dia. Ambos combinam que Katow fará o ataque e Kyo cuidará da distribuição das armas por um caminhão.

${ }^{213}$ MALRAUX. "La Condition Humaine" In Ouvres Complètes - p. 528. 
Kyo entra em sua casa e conversa com seu pai (ex-professor de sociologia da Universidade de Pequim, que, cassado por um outro governo, não mais agia) sobre Clappique, e Gisors diz que "sa mythomanie est un moyen de nier la vie, n'est-ce pas, de nier, et non pas d'oublier" ${ }^{214}$. Paciente, Gisors o era não devido ao budismo, mas às drogas, ao ópio. E quando seu filho conta da sensação estranha de não reconhecer sua voz gravada no disco, o pai diz que é porque escutamos nossa voz pela garganta e a dos outros com os ouvidos, e a sensação é a de não nos reconhecermos diante de um espelho no qual nos vemos de imprevisto.

Kyo se dirige a seu quarto inquieto com a insurreição que logo aconteceria e que poderia dar dignidade aos seus (embora ninguém o visse como chinês). Sua mulher, May, alemã nascida em Xangai, médica que trabalha em um hospital clandestino, chega e fala de seu dia, das mulheres que atendeu e que tanto sofrem, do próprio sentido do sofrimento ("la souffrance ne peut avoir de sens que quand elle ne mène pas à la mort, et elle y mène presque toujours") ${ }^{215}$; e ao longo do diálogo, confessa que deitara com um outro homem.

Diante dessa confissão, Kyo finge indiferença, diz que ela era livre, mas seus gestos mostram amargura e sofrimento, solidão frente a essa mulher que tanto amava e que podia lhe fazer sofrer. "Kyo souffrait de la douleur la plus humiliante: celle qu'on se méprise d'éprouver. Réellement elle était libre de coucher avec qui elle voulait. D'où venait donc cette souffrance sur laquelle il ne se reconnaissait aucun droit, et qui se reconnaissait tant de droits sur lui?"216.

Enquanto Kyo pensa em sua mulher, na solidão e incompreensão, Clappique chega a sua casa e lhe informa que tudo dera certo. Kyo parte com Katow, mas na rua não consegue parar de pensar em sua mulher: "'Mais moi, pour moi, pour la gorge, que suis-je? Une espèce d'affirmation absolue, d'affirmation de fou: une intensité plus grande que celle de tout le reste. Pour les autres, je suis ce que j'ai fait"'217. Só para May ele era cumplicidade e um semelhante, enquanto os outros homens eram seu juiz, aqueles que o olham.

Enquanto Kyo e Katow andam pelas ruas e vão em busca das armas no navio, Gisors pai lembra de seu antigo aluno Tchen, que chega e logo diz que foi ele quem

\footnotetext{
214 IBIDEM - p. 539.

${ }^{215}$ IBIDEM - pp. $542-543$.

${ }^{216}$ IBIDEM - p. 545.

${ }^{217}$ IBIDEM - p. 548.
} 
matou Tang Yen-ta, aquele homem da primeira cena e que "Je suis extraordinairement seul" 218 .

Diante da fala de Tchen, de seu horror e atração pelo sangue, da morte que deseja possui-lo, Gisors percebe cada vez mais o isolamento de seu antigo aluno, da sua obsessão pela morte, que o levará ao terrorismo e à constatação de que "il n'aspire à aucune gloire, à aucune bonheur. Capable de vaincre, mais non de vivre dans sa victoire, que peut-il appeler, sinon la mort?" ${ }^{219}$. Gisors via em Tchen o homem que preferia o sangue ao combate, que não sentia essa destinação à morte como uma angústia mas como uma fatalidade. E quando Tchen vai embora, sem a compreensão que esperava encontrar de seu mestre, Gisors começa a se lembrar desse seu ex-aluno da Universidade de Pequim, que órfão, fora criado por um tio e educado por um pastor mas que adquirira pavor da contemplação, e largado em uma China destruída, formado mas sem emprego, volta-se, com raiva, para a ação e contra o cristianismo. Se em Kyo, seu filho, a educação japonesa o deixava indiferente ao cristianismo e com a certeza de que havia um sentido em sua vida (o de dar dignidade aos homens), para Tchen isso não ocorria: sua vida e educação o precipitavam à ação política de modo que essa representasse, não só uma questão social mas também pessoal.

Do mesmo modo que Tchen e Kyo, Gisors também sente a extrema solidão diante da morte, diante de si mesmo. Nossos três personagens, de certo modo unidos nessa insurreição e ligados a outras pessoas por laços familiares e/ou de amizade, mantém-se separados, solitários. Parece sempre haver algo impossível de transmitir, de comunicar e compartilhar: como fazer com que alguém nos ouça por nossa garganta e não por seu ouvido? Kyo pensa que May consegue isso, mas não a ponto de juntar-se a ele, de fazê-lo sair da solidão perante a morte. O amor e o ópio seriam meios de tentar fugir dessa solidão que os angustia e atormenta?

É à ação que o narrador se volta. Deixando Gisors e seu ópio, vamos ao encontro de Katow em sua aventura no navio para pegar as armas (se o negócio foi simples, a atmosfera de luta o fez lembrar-se da batalha na qual fora preso na Lituânia por um dia, até a cidade ser tomada novamente pelo exército comunista) e de Kyo no caminhão, distribuindo essas armas na madrugada (como se fosse um leiteiro), já preparando as centrais e os postos para a greve geral do meio-dia e para a insurreição, que deveria acontecer uma hora depois.

\footnotetext{
${ }^{218}$ IBIDEM - p. 550.

${ }^{219}$ IBIDEM - p. 553.
} 
Às 4 h30 da manhã o dia 21/03 termina e às 11 da manhã do dia 22 a segunda parte do romance começa. O personagem que agora aparece não é nenhum dos que já tinham aparecido na primeira parte (Tchen, Kyo, Katow, Hemmelrich, Gisors, May, Clappique), mas sim Ferral, o presidente da Câmara de Comércio Francês, que ia em seu carro (e em meio à multidão de chineses na rua) até a polícia francesa.

Se toda a primeira parte é dedicada aos chineses (que nunca são totalmente chineses - Kyo teve educação japonesa, Tchen fora educado por um pastor em um colégio luterano e May, embora nascida na China, vivera quase toda sua vida na Europa; só Gisors parece ser chinês, e ele não age) ou aos que estão ligados ao Partido Comunista Chinês (caso do russo Katow e do belga Hemmelrich), a segunda parte inicia com um personagem francês que era contra a insurreição que estava sendo preparada em Xangai, e que fora à polícia francesa justamente para saber do diretor Martial como estava o andamento da insurreição, se havia o perigo dos comunistas tomarem a cidade sozinhos ou se teriam que esperar por Tchang Kaï-chek e as decisões do Kuomitang.

Ferral pensa que os revolucionários e o Kuomitang terão que decidir se Xangai será uma democracia ou o comunismo, e nesse caso, o Consórcio franco-asiático e todo o comércio francês de Xangai iriam desabar. É por isso que a relação de Tchang Kaï-chek com os comunistas interessava muito a esse francês que soubera ter prestígio em Xangai - ainda mais quando esse general mostrava, em seu último discurso, discordar das ações do Partido Comunista, que deveria se submeter às determinações do Kuomitang. O poder de Ferral estava nas mãos de Tchang: se esse general impedisse os comunistas de assumirem a cidade, seus negócios poderiam continuar.

Sem mais notícias, volta ao carro e se defrontra novamente com a multidão, com a qual o choffer tentava disputar espaço na rua, enquanto Ferral pensava em suas estratégias para ganhar mais dinheiro, voltar à França e reconquistar o poder que perdera nesse país. Mas de repente "l'auto s'arrêta. Le silence - la foule chinoise est d'ordinaire une des plus bruyantes - annonçait une fin du monde"220. Todas as lojas fecham as portas, o choffer sai do carro e Ferral se encontra só em meio à multidão que agora pesadamente retornava para casa: era a greve geral que começava e nada restava ao francês senão também ir rapidamente para sua casa.

${ }^{220}$ IBIDEM - p. 572. 
Mas se o início da greve geral foi anunciado e visto por meio de um personagem que estava alheio às ações da insurreição; é à Tchen que o narrador retorna logo após o meio-dia, à 1 hora, em sua "permanência" com homens que também esperavam, armados. Mas nem mesmo em meio a seu grupo, esperando pelo combate e conquista de Xangai, Tchen conseguia sair de sua solidão: "Il n'était pas des leurs. Malgré le meurtre, malgré sa présence. S'il mourait aujourd'hui, il mourrait seul. Pour eux, tout était simple: ils allaient à la conquête de leur pain et de leur dignité. Pour lui... sauf de leur douleur et de leur combat commun, il ne savait pas même leur parler. Du moins savait-il que le plus fort de liens est le combat. Et le combat était là"221. Mas nem a mais forte ligação é capaz de tirá-lo da solidão na qual mergulhara: se para Kyo o amor era essa cumplicidade, para Tchen o combate o é, mas nenhum desses atos tão difíceis e profundos livra o homem de seu destino solitário e angustiante perante a morte.

O combate começa e Tchen e seu grupo atacam postos de polícia, mas os policiais entregam rapidamente suas armas e alguns até se juntam aos insurgentes (enquanto outros jogam cartas e dizem não ser responsáveis pelo que ocorre). Mas era preciso ocupar o posto central (um antigo hotel), que estava bem preparado para o combate. E se os sentinelas e alguns policiais se renderam fácil, um dos oficiais vê os insurgentes e do primeiro andar comanda a defesa do posto e começa a atacá-los com granadas jogadas na rua e destruindo parte do térreo, machucando e matando vários homens. Mas de fora do prédio aparecem outros insurgentes que tentam combater os policiais no primeiro andar (não sem antes atacar os próprios companheiros). E logo o fogo começa a dominar o posto e Tchen tem de fugir: encostado no muro, consegue chegar às tropas que estavam reunidas no prédio da frente, embora tenha se ferido outra vez no braço esquerdo.

Logo um caminhão blindado chega com jovens burgueses (os quais Tchen despreza - ao menos o proletário era a forma de sua esperança) e o chefe da equipe de socorro informa que quase todos os portos já tinham sido tomados e que era preciso subir ao telhado e lançar granadas nas janelas do primeiro andar (assim como os policiais do primeiro andar faziam com o térreo). E desse modo conseguem matar e ferir os oficiais, e se encaminham agora até a Estação de trem do sul.

${ }^{221}$ IBIDEM - p. 574. 
A tomada da estação será contada de novo por meio de Ferral, que em seu estúdio recebia Martial e um enviado de Tchang Kaï-chek, o qual desejava saber qual seria a posição da polícia francesa em caso de ruptura entre o Kuomitang e os comunistas, o que com certeza aconteceria, já que estes eram traidores e tinham mais interesse no comunismo que na China unificada.

Enquanto conversam e Ferral tenta convencer o chefe da associação de banqueiros de Xangai a financiar Tchang Kaï-chek contra os comunistas em troca de algumas promessas, o telefone toca várias vezes para informá-los que os comunistas estão tomando a cidade chinesa, mas ainda não tomaram a Estação do Norte.

E se Ferral só tinha aparecido em meio a seus negócios, agora o narrador nos faz vê-lo em um quarto ao lado de Valérie, mulher com quem ele já dormira algumas vezes mas com quem pensava nunca se ligar ("la nature de Ferral, et son combat présent, l'enfermaient dans l'érotisme, non dans l'amour") ${ }^{222}$. Homem que busca obter novamente o poder na França, que tem orgulho e não se liga a ninguém, Ferral, ao contrário de Valérie, pensa que "se donner, pour une femme, posséder, pour un homme, sont les deux seuls moyens que les êtres aient de comprendre quoi que ce soi..." 223 .

Valérie se mostra uma mulher inteligente e feminista, com liberdade de espírito (o que irritava Ferral), e diz a ele que tudo é, na verdade, um jogo, e que as mulheres não se dão jamais (ou quase jamais) e os homens não possuem nada. Assim como May, médica que ama o marido Kyo e que não se importa em trai-lo com outro quando a morte está tão próxima e torna tudo indiferente, Valérie tem personalidade forte e contraria seu amante Ferral, mostrando a ele o jogo de ilusões que é possuir e ser possuída.

Essas são as duas mulheres dos romances de Malraux e serão quase que as únicas. Se nos contos de juventude os personagens que agiam, mesmo não sendo humanos, eram sempre com artigo masculino (o pecado Orgulho, o músico), nos dois primeiros romances aqui analisados (Les Conquérants e La Voie Royale) as mulheres só apareciam como objeto sexual dos principais personagens - elas nada são além de prostitutas que aparecem para satisfazer a vontade de dominação dos homens (apenas uma mulher não tem esse papel, mas é uma mulher morta: Sarah). Já aqui elas têm voz e falam, e falam contra os homens; mesmo amando-os, elas mostram um outro

\footnotetext{
${ }^{222}$ IBIDEM - p. 594.

${ }^{223}$ IBIDEM - p. 596.
} 
modo de se relacionar com a vida e com os outros, embora ainda seja quase sempre a voz masculina que domine.

Por mais que May e Valérie falem e se mostrem emancipadas em sua voz, elas nunca são o sujeito da ação, o narrador nunca as acompanha, lhes dando uma vida que seja independente da dos homens. A presença do homem é mais forte - e o que o narrador diz é o que elas sentem diante da presença de um olhar masculino e não em relação a seus atos (e é significativo que, na hora do sexo, seja Ferral a vencer e a impor que a lâmpada ficará acesa. Mesmo que Valérie brigue e apague a luz várias vezes, é ele quem domina e a faz sentir-se desprezada, a ponto de resolver não perdoálo por isso e se vingar). É com o olhar de Ferral à Valérie dormindo (objetivando-a, portanto, dizendo que "elle n'était rien que l'autre pôle de son propre plaisir") ${ }^{224}$ que o narrador os abandona para então relatar o ataque a um trem blindado, às 4 da manhã.

Isolado, o trem do governo tentava resistir ao ataque das tropas comunistas, que são informadas que o Comitê executivo que iria organizar o governo municipal de Xangai após a tomada da cidade não era, em sua maioria, comunista, e logo a seguir são informadas que o novo prefeito é de direita, o que faz Kyo pensar: "La ligne de l'Internationale semble être de laisser ici le pouvoir à la bourgeoisie. Provisoirement... Nous serons volés. J'ai vu des courriers du front: tout mouvement ouvrier est interdit à l'arrière. Tchang Kaï-chek a fait tirer sur les grévistes, en prenant quelques précautions" 225 .

Logo chega Katow com mais confirmações dessa estratégia de Tchang Kaïchek, como a de que pediria aos comunistas para entregar as armas a suas tropas, assumindo ainda mais o poder da cidade. Enquanto discutem o que farão (com Tchen já pensando em matar Tchang), um oficial do Kuomitang chega e pede para os comunistas darem suas armas para ajudar Tchang, o que era uma ordem de Han-k'eou (sede da Internacional na China). Kyo responde que não sabe se conseguirá, no momento, recuperar muitas armas.

Ao ficarem sozinhos, Kyo decide ir até Han-K'eou (cidade que estava em greve e com grande tropa comunista) ver qual era a decisão da Internacional e o motivo dela, já que lhes parecia óbvio que Tchang Kaï-chek era mantido pelos burgueses e dar armas a ele era renunciar à China comunista. Barulhos surgem

\footnotetext{
${ }^{224}$ IBIDEM - p. 598.

${ }^{225}$ IBIDEM - p. 600.
} 
estrondosos: as forças revolucionárias chegam e atacam o trem blindado, fazendo os soldados do governo morrerem.

Com todos os postos e edifícios públicos tomados e com o trem derrotado, o governo de Xangai nada mais significava. Os comunistas tinham tomado o poder da cidade e agora as tropas de Tchang Kaï-chek chegavam para dar o último tiro da vitória. A questão, agora, não era mais como conquistar a cidade mas decidir quem iria governá-la.

E diante do pedido do Kuomitang para que os comunistas dêem suas armas a Tchang Kaï-chek, uma rendição para os comunistas, Kyo viaja para Han-K'eou e ali chega no dia 29/03, seis dias depois de deixar Xangai, e já no porto começa a perceber que a cidade na qual todos os comunistas se inspiravam para fazerem sua insurreição não era, na verdade, o que a propaganda dizia. Ao invés do sucesso da insurreição, Kyo vê um porto quase parado, sem comércio algum. A concessão fora abandonada pelos ingleses mas nem os bancos tinham sido ocupados, a cidade não tinha adquirido vida. Ao andar até a delegação da Internacional, Kyo via que tudo era uma ilusão e que "si Han-K'eou n'était pas ce que chacun croyait qu'elle était, tous les siens, à Shangai, étaient condamnés à mort" 226 . Ao falar com o secretário Vologuine isso fica ainda mais patente. Este diz que sair do Kuomitang e organizar um partido comunista independente seria, agora, impossível e vão; fazer isso era colocar Tchang Kaï-chek contra eles, o que significaria uma derrota certa para os comunistas. A única coisa que lhes restava era demolir Tchang mas se servindo dele (do mesmo modo que combatiam generais do norte se unindo a Tchang, logo o destruiriam também): "La révolution ne peut pas se maintenir, enfin, sous sa forme socialiste. Il faut la laisser faire. Il s'agit de l'accoucher. Et pas de la faire avorter" ${ }^{\prime 22}$.

Vologuine é, assim, um representante ortodoxo da política stalinista, dos comunistas neomarxistas que acreditavam na inevitablidade da Revolução comunista e na fatalidade da história: a revolução vai ocorrer de qualquer maneira e para isso acontecer, o melhor é esperar, é deixar com que quase tudo ocorra como tem de acontecer - e se aquele não era o momento certo, a pior coisa a fazer seria atropelar os acontecimentos e se separar de Tchang Kaï-chek. Era necessário deixar a revolução dormir para então acordar mais forte. Confrontar-se com Tchang e suas tropas seria abortar o "filho" que certamente nasceria ao fim dos nove meses.

\footnotetext{
${ }^{226}$ IBIDEM - p. 608.

${ }^{227}$ IBIDEM - p. 611.
} 
Mas a resposta de Kyo mostra o quanto ele não concorda com a ortodoxia da Internacional (do mesmo jeito que Garine era contra Borodine por isso): "Mais il y a dans le marxisme le sens d'une fatalité, et l'exaltation d'une volonté. Chaque fois que la fatalité passe avant la volonté, je me méfie"228. Para Kyo, que luta para transformar Xangai numa cidade comunista e assim dar dignidade aos seus, o sentido da fatalidade, de ortodoxia o irrita - a exaltação da vontade deve ser, para ele, sempre superior às ordens que levam ao fatalismo e condenam a vontade, a ação, o desejo de mudar.

No entanto, Vologuine continua a afirmar que a Internacional, Borodine e até mesmo Moscou ordenaram aos comunistas a entrega das armas a Tchang Kaï-chek ainda não era a hora de romper com ele.

Kyo insiste e começa a pensar que, desse modo, o projeto de Tchen de matar Tchang começa a ter mais valor, e por isso avisa Vologuine da intenção do amigo, e é quando este revela que Tchen também estava em Han-K'eou e queria falar com ele, mas que decidira deixá-lo esperando. Agora, no entanto, pede para Tchen entrar e logo lhe diz que a Internacional é contra os seus projetos e que Tchang Kaï-chek tem seu filho em Moscou e por isso não iria assassinar os comunistas. Enquanto Vologuine fala isso a Tchen, Kyo pensa que o secretário fora muito mais duro ao ordenar a entrega das armas que agora, quando dizia a Tchen que não era hora de matar Tchang.

Os dois - Kyo e Tchen - continuam a discutir, dizendo que a base do partido não entenderá a entrega das armas, que isso soará como traição, ao que Vologuine, com uma voz apaixonada, diz "Même coolie du port de Shangai, je penserais que l'obéissance au parti est la seule attitude logique, enfin, d'une militant communiste. Et que toutes les armes doivent être rendues" ${ }^{\prime 22}$. Assim como falava da fatalidade da história, da ortodoxia das regras e ordens, agora é à obediência que Vologuine apela; e se Kyo opôs à fatalidade a vontade, agora é a vez de Tchen contrariar essa ordem da Internacional: "Ce n'est pas par obéissance qu'on se fait tuer. Ni qu'on tue. Sauf les lâches"230.

\footnotetext{
${ }^{228}$ IBIDEM - p. 611.

${ }^{229}$ IBIDEM - p. 616.

${ }^{230}$ IBIDEM - p. 616.
} 
Ambos saem da delegação da Internacional e caminham na noite escura e vazia de Han-K'eou, com Kyo sentindo-se extremamente ligado a esse homem que ele sabe que logo se matará.

Tchen afirma que irá embora para Xangai e que conseguirá isso mesmo sem ter permissão, o visto. Kyo decide visitar Possoz, o único homem da Internacional que ele conhecia e em quem confiava. Mas mesmo ele afirma que é preciso ter confiança no Komitern, e ao mostrar a lista de homens que tentam embarcar clandestinamente e que serão presos por isso, Kyo vê que Vologuine não comunicara o nome de Tchen, o que o faz entender o porquê o secretário tinha reprovado Tchen mas sem a mesma firmeza e hostilidade com que tinha repreendido a não entrega das armas: "Le Komitern ne veut pas prendre la responsabilité de faire tuer Tchang Kaï-chek, pensa Kyo: mais peut-être accepterait-il sans désespoir que ce malheur arrivât..."231 ${ }^{2}$ E ao ver que a Internacional iria perseverar nesse comando, Kyo volta para Xangai desiludido.

É com Clappique (já no dia 11/04) que a quarta parte de La Condition Humaine inicia. No bar de um pequeno hotel, ele conversa com Chpilewsli, polonês da Polícia, que pede para que ele deixe a cidade de Xangai no dia seguinte, já que a polícia conhecia a história do roubo das armas e da participação do barão nelas, e que tanto Clappique quanto Kyo (o "pequeno Gisors") eram visados pela polícia. E se no início Clappique continua a fazer brincadeiras e não levar nada a sério, logo depois ele "se découvrait tout à coup homme de sérieux et de pois. Comme il ne se jugeait jamais responsable de lui-même, il en fut surpris" ${ }^{232}$.

Enquanto Clappique pensa em avisar do risco que Kyo corria, Tchen vai ao encontro de dois companheiros, Souen e Peï (esse ainda adolescente). Os três vão até a avenida das Duas Repúblicas esperar pelo carro de Tchang Kaï-chek, que passaria ali entre uma hora e uma hora e quinze. Tchen fica em uma loja esperando o carro e dali soltaria a primeira bomba e avisaria os outros dois, que ficariam logo depois.

Tchen entra na loja de antiquários, finge ver alguns objetos, mas o dono da loja não para de lhe fazer perguntas, e para disfarçar, ele começa a comprar pequenos e baratos objetos. Mas logo ele ouve o barulho de um carro vindo e começa a sair. No entanto, o dono da loja o segue com um objeto, insistindo para que ele compre e o

\footnotetext{
${ }^{231}$ IBIDEM - pp. $625-626$.

${ }^{232}$ IBIDEM - p. 630.
} 
segura pela bolsa: "Tchen ne voyait plus rien, mou comme s'il allait s'évanouir: l'auto passait" ${ }^{233}$. Sai correndo mas vê que também Peï e Souen não tinham atirado a bomba. Os três se reúnem e vão em direção à casa de Hemmelrich, que nega ajuda a Tchen. Mesmo querendo ajudar, seu filho grita e chora de dor e Hemmelrich tem medo que a polícia mate a mulher e a criança. E quando Tchen sai, ele ainda se justifica: "Tu ne peux pas savoir, Tchen, tu ne peux pas savoir le bonheur que tu as d'être libre!..."234. Ao mesmo tempo em que não deseja ajudar para preservar a vida doente e sofrida de seu filho, ele se sente preso por essa decisão. Gostaria de ser livre, de poder sair com Tchen com uma bomba para acabar com todo sofrimento e miséria, mas esse belga saído de uma guerra na Europa foi para a Indochina e lá acolheu uma mulher (comprada por 12 dólares e logo abandonada por seu comprador) que aos poucos começa a cuidar dele e acabam por dormirem juntos e fazem um filho - e assim sentese preso a eles, sem poder nem agir nem cuidar bem deles.

Tchen ainda acredita que há uma maneira de não fracassar: "Et je crois qu'il n'y en a qu'un: il ne faut pas lancer la bombe; il faut se jeter sous l'auto avec elle"235. O que Tchen propõe não é mais jogar bombas em um carro e correr o grande risco de ser morto pela guarda de Tchang Kaï-chek, mas sim se jogar com a bomba e certamente morrer. Diante dessa proposta que o atrai cada vez mais, Souen recusa e diz preferir tentar várias vezes e errar do que tentar uma só e saber que não poderá mais tentar nenhuma, mas o adolescente Peï, chorando em silêncio, mostra-se disposto a seguir Tchen nesse atentado. No entanto, Tchen pede a ele que explique aos outros por meio da escrita a importância e significado do gesto que irá fazer (ao invés de agir, Peï deve testemunhar e explicar o que se passa. Se é necessário que alguém aja, é necessário também que alguém testemunhe e escreva, transmita a outros o ato e o perpetue).

E se Peï fica a observar Tchen, que vai sozinho matar Tchang Kaï-chek, Clappique chega à casa de Gisors para avisar Kyo que ele está sendo procurado pela polícia, mas como este não estava, fica a conversar com o pai e Kama (pintor japonês), que explica a diferença entre a pintura para os europeus e para os orientais (enquanto os primeiros falam deles mesmos, os segundos se interessam pelo mundo) e que "aller du signe à la chose signifiée, c'est approfondir le monde, c'est aller vers

\footnotetext{
${ }^{233}$ IBIDEM - p. 638.

${ }^{234}$ IBIDEM - p. 640.

${ }^{235}$ IBIDEM - p. 644.
} 
Dieu"236 $^{23}$. Mas logo Kyo chega e Clappique o avisa que era preciso fugir em menos de 48 horas para não ser morto, ao que Kyo responde que não tem a intenção de fugir mas que passaria entre 23 e $23 \mathrm{~h} 30$ no Black Cat para dar a Clappique parte do dinheiro que este necessitava para fugir.

Kyo então comunica a Gisors e a May que a polícia vai procurá-lo e que as tropas da Primeira Divisão (que era em sua maioria comunista) já deixaram a cidade, o que anunciava uma repressão iminente por parte de Tchang Kaï-chek - tornada mais fácil pela decisão da Internacional de entregar as armas dos comunistas ao general. Quando May diz que irá junto com ele ao Comitê Central, Kyo discute e diz que agora era a vez dela reconhecer a liberdade dele, mesmo que sofresse com isso. Nesse momento, Kyo sente que algo mudara entre eles e que se antes via nessa mulher a cumplicidade, a única pessoa capaz de ouvi-lo pela garganta e não pelo ouvido, agora ela era um "outro", tão ou quase tão estranha quanto os outros, tão inacessível quanto eles. Ela deixa escorrer uma lágrima, mas não chora. Insiste em ir junto com ele e diz que nunca viveu como uma mulher que é preciso proteger. Triste, Kyo a abraça e vai embora, sozinho.

Katow logo encontra Kyo e pergunta sobre Tchen, pois o procurara a tarde toda para avisá-lo que a polícia tinha colocado vários carros iguais ao de Tchang Kaïchek na rua para confundirem os terroristas, e decide ir até a casa de Hemmelrich.

Kyo fica novamente sozinho e a imagem de May se torna ainda mais forte na ausência, fazendo-o voltar correndo à casa para levá-la consigo. "Il comprenait maintenant qu'accepter d'entraîner l'être qu'on aime dans la mort est peut-être la forme totale de l'amour, celle qui ne peut pas être dépassée" ${ }^{237}$. Sem nada dizer, May o segue.

3h30, Katow está na casa de Hemmelrich e pergunta sobre Tchen, conversam sobre a criança e Katow diz compreender um pouco o que aquele sente por não ter ido com Tchen e por não tê-lo escondido. Hemmelrich contina a se culpar por não ter ajudado Tchen mas também sabia que não podia fazê-lo. Katow pensa em uma mulher que amara e que só a morte o livraria dessa angústia, mas nada fala, pois não há palavras que podem expressar essa "afeição viril". Deixa Hemmelrich sozinho e sai à procura de Tchen.

\footnotetext{
${ }^{236}$ IBIDEM - pp. $649-650$.

${ }^{237}$ IBIDEM - p. 660.
} 
E se os comunistas, que agora tentarão se defender de Tchang Kaï-chek, estão quase todos em momentos decisivos (Tchen no ataque terrorista, Kyo sendo perseguido pela polícia, Hemmelrich na angústia de querer agir e não poder), e mesmo Clappique se encontra em situação complicada por ter ajudado os comunistas; o narrador abandona todos esses para voltar-se para Ferral, o único personagem que deseja a vitória de Tchang Kaï-chek, colocando o destino dos comunistas em suspenso, esperando por algo que não depende deles.

Ferral conversa com um general, que o informa do comando de Tchang para fuzilar os líderes comunistas, e depois disso, decide visitar Valérie, indo antes comprar um presente que ela pedira. Quando chega ao hotel em que Valérie estava, descobre, pelo porteiro, que ela avisara que não viria e que era pra Ferral conversar com um homem que estava no hall, o jovem diretor de um banco inglês que também cortejava Valérie, e que estava ali também com um presente pedido por ela (ele com um melro macho e Ferral com um melro fêmea). Ambos se olham e logo entendem o que acontecera. O inglês vai embora mas Ferral continua no hotel. "Ferral s'éfforçait de réfléchir, de se défendre. Elle l'avait atteint à son point le plus sensible, comme si elle lui êut crevé le yeux pendant son sommeil: elle le niait" ${ }^{238}$, e por isso era necessário se vingar, continuar ali mas não se deitar com ela. A raiva cresce ainda mais quando o porteiro lhe entrega uma carta de Valérie na qual ela diz "je ne suis pas une femme qu'on a, un corps imbécile auprès duquel vous trouvez votre plaisir en mentant comme aux enfants et aux malades. Vou savez beaucoup de choses, cher, mais peut-être mourrez-vous sans vous être aperçu qu'une femme est aussi un être humain" 239 .

Valérie recusa ser o que Ferral quer (só um corpo que ele possui), assim como May recusa o desejo de Kyo (o de ser uma mulher que é necessário proteger). Mas se o amor de Kyo o faz, não sem discussões, reconhecer a cumplicidade de sua mulher, a afirmação de Valérie apenas incita ainda mais o desejo de possessão de Ferral. O orgulho sexual crescia em Ferral, e com ele o desejo de se vingar. Rapidamente vai a uma loja de animais e compra vários pássaros. De volta ao hotel, vai ao quarto de Valérie (que não estava) para lhe fazer uma surpresa: solta todos os animais que comprara no quarto, por cima da cama, para deixar a imagem de sua cólera.

\footnotetext{
${ }^{238}$ IBIDEM - p. 669.

${ }^{239}$ IBIDEM - p. 670.
} 
Vai então ao Círculo Francês, a um bar e lá encontra Gisors (que fora ouvir os rumores do dia), com quem conversa e logo pergunta se é possível conhecer outra pessoa, ao que o velho responde: "la connaissance d'un être est un sentiment négatif: le sentiment positif, la réalité, c'est l'angoisse d'être toujours étranger à ce qu'on aime" 240 . Apenas o tempo dá, não o conhecimento, mas a cessão do sentimento de ignorância, o que elimina a angústia. Conhecer alguém é possui-lo, é destrui-lo - e se o tempo nem sempre ajuda a eliminar de vez a angústia, é preciso se intoxicar, seja no haxixe ou na mulher (escape dos "ocidentais"), no assassinato (para Tchen), na loucura (para Clappique), na revolução (para Katow), no amor (para May) ou no ópio (para Gisors) $^{241}$.

Mas Ferral não consegue deixar de pensar em fazer sexo com uma mulher para vingar o desprezo de Valérie por ele. Busca uma cortesã chinesa e a leva a sua casa, não para procurar o prazer, mas para se encontrar no prazer: "il ne couchait jamais qu'avec lui-même, mais il ne pouvait y parvenir qu'à la condition de n'être pas seul" ${ }^{242}$.

Depois de acompanhar Ferral por toda a tarde e noite o narrador o deixa para voltar a Tchen. O clímax é interrompido por muitas páginas e ele volta no momento mesmo em que o sexo de Ferral se inicia. De um clímax o narrador nos leva a outro: ao instante no qual Tchen aguarda, sozinho e à noite, a passagem do carro de Tchang Kaï-chek, que logo se mostra ao longe e Tchen "courut vers elle [l'auto] avec une joie d'extatique, se jeta dessus, les yeux fermés" ${ }^{243}$.

Tchen se joga com a bomba sobre o carro de Tchang Kaï-chek ${ }^{244}$ e logo sente a dor, o sofrimento. A alegria, o êxtase dão lugar ao sofrimento, visível ainda mais na imagem que o narrador pinta: a do homem ensangüentado jogado no chão procurando um revólver em sua calça e descobrindo que não há mais bolso, nem calça, nem perna: só há carne. Mas a força de Tchen é ainda maior que seu sofrimento: pega outro revólver que estava na camisa e abre os olhos. Ao ver um policial ao lado dele, pensa em perguntar se Tchang Kaï-chek estava morto, "mais il voulait cela dans un autre monde; dans ce monde-ci, cette mort même lui était indifférente" 245.

\footnotetext{
${ }^{240}$ IBIDEM - p. 677.

${ }^{241}$ Só Kyo, para seu pai Gisors, consegue resistir à intoxicação.

242 IBIDEM - p. 682.

${ }^{243}$ IBIDEM - p. 684.

${ }^{244}$ Será que é o carro dele? Se Tchen não tem dúvidas, o leitor, com a informação dada anteriormente por Katow, tem.

${ }^{245}$ IBIDEM - p. 684.
} 
A vitória de Tchen perde seu sentido no momento mesmo em que ela ocorre. Tchen se torna indiferente ao seu ato, à sua morte e à provável morte de Tchang Kaïchek. Todas as vitórias dos livros de Malraux vêm acompanhadas de dor, doença, morte e indiferença (se o decreto é assinado em Les Conquérants, é a imagem da despedida e morte próxima de Garine que fecha o livro e nos impressiona; se os baixo-relevos são encontrados em La Voie Royale, é a figura de Perken morrendo no meio da floresta que nos fica, e aqui, se Tchen realmente conseguiu matar Tchang Kaï-chek, é ainda a dor e indiferença em relação a essa morte que o narrador nos relata).

Parece-nos que a vitória, ao mostrar que não era nela que seria possível encontrar o sentido da vida e das ações, deixa de interessar aos heróis. Há uma certa desistência da resistência - o personagem se entrega à morte e torna, com isso, indiferente seus atos (ao invés de valorizá-los diante dessa atitude extrema, eles o tornam indiferentes, tão absurdos quanto a luta que desejaram empreender).

Tchen se joga sobre o carro de Tchang Kaï-chek e alcança seu objetivo, mas isso já perdeu toda sua importância e significado. Só o que não é indiferente é seu sofrimento, a dor na perna estilhaçada e contra tudo isso, só resta entregar-se: nosso personagem põe o revólver em sua boca e sem perceber (ao recebr um chute de um policial), atira em si mesmo.

Se a morte de Tchang Kaï-chek pode mudar a história e o rumo da Revolução, ela não muda o destino de Tchen, que se mata sem nem mesmo perceber. Diante desse destino certo, absurdo e doloroso, que poderia significar o êxito ou o fracasso, a morte ou a vida de um general? Tchen, em sua extrema dor e solidão, vê tudo tornar-se nulo, tudo tornar-se igual em sua indiferença - só a Morte sobrevive.

E se Tchen morre sem saber se matou Tchang Kaï-chek, o narrador continua com o suspense e não revela ao leitor se o general morreu. É com Clappique que ele inicia a quinta parte do livro. Às $11 \mathrm{~h} 15$, no horário em que Kyo combinara de se encontrar com ele para entregar o dinheiro para a viagem, Clappique decide passar antes em uma casa de jogo para conseguir mais dinheiro. $\mathrm{O}$ barão entra no salão de jogos para arriscar seus 117 dólares sempre no número par. E perdendo uma vez, ganhando outra, o tempo passava e já não haveria como encontrar Kyo. Mas Clappique não se importa mais com isso: o jogo o obceca, o azar e a sorte, o destino o domina: "il découvrait que le jeu est un suicide sans mort: il lui suffisait de poser là 
son argent, de regarder cette boule et d'attendre, comme s'il eût attendu après avoir avalé un poison; poison sans cesse renouvelé, avec l'orgueil de le prendre"246. Fascinação, encantamento, necessidade - tudo isso ligava Clappique ao jogo, do qual ele só sai à 1 hora, após o salão ter fechado, e com apenas 24 dólares.

Sai da casa de jogos, perambula pela rua e acaba por entrar em um pequeno bordel. Uma prostituta senta ao seu lado e começam a beber e a falar do ópio. E antes de subirem ao quarto, Clappique pede para ela ser gentil, pois seria a última noite que ele se deitaria com uma mulher. E como ela acreditou nessa história criada por ele, ele também passa a acreditar: "Quand il disait qu'il se tuerait, il ne se croyait pas; mais, puisqu'elle le voyait, il entrait dans un monde où la vérité n'existait pas. Ce n'était ni vrai, ni faux, mais vécu. Et puisque n'existaient ni son passé qu'il venait d'inventer, ni le geste élémentaire et supposé si proche sur quoi se fondait son rapport avec cette femme, rien n'existait. Le monde avait cessé de peser sur lui" ${ }^{247}$.

Clappique deseja, como Gisors já tinha dito a seu filho, negar o mundo e seu peso. O vivido ao qual recorre não é o vivido real mas sim o imaginado. Ele quer se refugiar no mundo imaginário, na fantasia, no farfelu - a imaginação é seu modo de viver, um modo que o encanta e o embriaga, fazendo-o se esquecer da angústia e ter coragem de sonhar com atitudes que ele nunca teria (como quando jogava e pensava em ganhar dinheiro não para fugir mas para ficar).

E enquanto Clappique ainda jogava no salão, Kyo e May o esperam no bar Black Cat. Kyo conseguira juntar quase 200 dólares, mas Clappique não aparecia. Lá descobrem que alguém tentara matar Tchang Kaï-chek, mas que ele não estava no carro (só aqui ficamos sabendo que Tchen não conseguira matar o general). Kyo deseja que Tchen tenha escapado com vida e decide não mais esperar por Clappique. Junto com May, anda até o Comitê Central e pensa na resistência impossível, mas homens aparecem no meio da noite e os surpreendem, batem em May, que desmaia, e levam Kyo em seu carro.

À meia-noite, sem saber ainda da retenção de Kyo, Hemmelrich vai à rua informar-se sobre o atentado de Tchang (e na calçada vê o corpo de Tchen morto), passa em um posto e descobre que todos os comunistas estão sendo fuzilados, e que é preciso então salvar a mulher e o menino. Volta para casa e logo vê a porta da loja de discos aberta e discos e sangue esparramados no chão, sangue de sua mulher e de seu

\footnotetext{
${ }^{246}$ IBIDEM - p. 689.

${ }^{247}$ IBIDEM - p. 693.
} 
filho, que ao menos agora não sofria mais. Mais que a morte, o que o aterrorizava era o sofrimento que esses corpos podiam ter sentido antes de morrer. E "malgré son effondrement, cette sensation de coup de bâton à la base du cou, ses épaules sans force, il ne pouvait chasser de son attention la joie atroce, pesante, profonde, de la libération" ${ }^{248}$. Como Katow pensara ao falar de Hemmelrich, a morte do filho que sofria o liberta. Agora este pode lutar, pode pegar granadas e explodi-las contra Tchang Kaï-chek; nada mais o retém. Eufórico, parte pensando que agora tudo ia começar e que ele podia se entregar à resistência. Vai até a permanência mais próxima e lá pede a Katow granadas e fuzil.

Novamente o narrador abandona essa cena de tensão (os comunistas em combate) para acompanhar longamente Clappique. Ele volta ao hotel (e sugestivamente o narrador nos faz saber que ele joga seu casaco por cima do livro de contos de Hoffmann) e bebendo um uísque diante de um espelho, representa para si mesmo caretas amendrontadoras e ri, numa espécie de delírio. Mas Gisors aparece e o obriga a voltar ao real, pede para que Clappique vá falar com König, o chefe de segurança de Tchang Kaï-chek, para ao menos não fuzilar Kyo. Clappique tenta falar com König, mas este logo o avisa que fora ele que dera dois dias de sobrevida a Clappique e que esperava vê-lo fugir logo. A cada réplica, o barão percebia que o chefe de segurança nada iria fazer por Kyo. Ao contrário, quando seu nome foi citado, a raiva surge na fala de König, ainda mais quando Clappique tenta justificar a vontade de dignidade que movia Kyo em sua revolução. König pergunta então se Clappique sabia o que os vermelhos faziam aos oficiais prisioneiros como a ele, alemão preso e levado à Sibéria: "mon petit, il vaudrait mieux ne pas trop me parler de dignité... Ma dignité à moi, c'est de les tuer" ${ }^{249}$. Sem sucesso algum e com a certeza que König não iria poupar Kyo, Clappique vai embora e nem precisa avisar Gisors, que já percebia pelo olhar do outro que tudo dera errado.

Sem poder salvar Kyo das mãos de König, o narrador volta para Katow e Hemmelrich (com Tchen morto e Kyo preso, só restam os dois comunistas), que esperam o inimigo combater. Logo as metralhadoras inimigas surgem e atiram sem parar. Katow é atingido e desmaia, e após uma detonação "surda", é Hemmelrich e os outros que desmaiam. Mas Hemmelrich logo acorda e percebe que tudo estava destruído e ninguém mais atirava. Rodeado por corpos mortos e/ou desmaiados, ele

\footnotetext{
${ }^{248}$ IBIDEM - p. 698.

${ }^{249}$ IBIDEM - p. 707.
} 
sai da casa e tenta ao menos matar um homem antes de se fazer prisioneiro: vê um oficial de Tchang Kaï-chek e o estrangula com raiva e dor. Veste então a roupa desse oficial e vê que é possível não morrer.

A sexta parte do livro inicia com Kyo na prisão provisória, em uma cela na qual estava um homem idoso, que costumava ficar ali (ele vendia mulheres e pagava à polícia para não ser preso. Mas às vezes faltava dinheiro e ele era preso). Ao receber comida uma voz diz que não vale a pena, pois é para amanhã, frase essa que o velho mandarim explica a Kyo: é a execução deste que era para amanhã. A todo momento uma voz grita "Comment, comment, comment allez-vous?" e um guarda começa a espancar esse homem louco. Kyo chama o guarda sob os olhares sádicos dos outros prisioneiros, que esperavam ao menos ouvir gritos "diferentes" de dor (e não apenas o do louco), e antes que pudesse falar, também é alvo do chicote. Sem sentir suas mãos, Kyo ainda tem coragem de propor ao guarda 50 dólares para parar de torturar o louco, o que ele rapidamente aceita.

Kyo estranha a atitude dos presos, quase todos desejando o sofrimento do outro, criando grupos (os presos políticos eram quase sempre odiados), e ao sair de lá e ir à Polícia especial "il lui semblait qu'il laissait là une part immonde de luimême" ${ }^{250}$. Ele é levado por um guarda (que via nele um japonês ou um europeu, mas nunca um chinês, e por isso o tratava bem) até König, que lhe dá um pão e pergunta se é verdade que Kyo é comunista por dignidade, ao que este responde que "le communisme rendra la dignité possible pour ceux avec qui je combats" ${ }^{251}$. Mas König, com raiva, não ouve a resposta e lhe propõe a vida em troca de dizer onde estavam as armas que eles esconderam de Tchang Kaï-chek, e Kyo diz não aceitar de maneira alguma essa proposta e prefere a tortura. König o manda então para o pátio.

Já Clappique, para não ser preso, tenta fugir. Vai até o cais sem passaporte e sem dinheiro para comprar passagem, e pensa em um modo de conseguir entrar em um navio. Ao fazer a barba em um lugar perto do cais, observa que um marinheiro entra no navio francês sem nada apresentar aos outros. Então Clappique, rei do fantástico, decide se vestir como um marujo: compra fantasia de marinheiro, volta ao cais e percebe no olhar dos outros o reconhecimento de um marinheiro, o êxito de seu disfarce, o que o leva a exacerbar sua negação da vida sempre desejada: "Non, les

\footnotetext{
${ }^{250}$ IBIDEM - p. 721.

${ }^{251}$ IBIDEM - p. 723.
} 
hommes n'existaient pas, puisqu'il suffit d'un costume pour échapper à soi-même, pour trouver une autre vie dans les yeux des autres" ${ }^{252}$. Confiante nesse novo homem que é, entra no navio e já conversa com um russo sobre a "vida a bordo", as aventuras que viveu, ao que o russo diz já ter viajado por mais de 7 anos e nunca ter visto essas coisas, e Clappique replica: "il faut introduire les moyens de l'art dans la vie, mon b'bon, non pour en faire de l'art, ah! bon Dieu non! mais pour en faire davantage de la vie" $^{253}$.

Mas é principalmente o antigo pátio que o capítulo narra. É ali que todos os comunistas capturados por Tchang Kaï-chek são levados, inclusive Katow. Esse olhava todos os homens estendidos sob o sol, quase todos machucados, deitados perto da estação de trem de Chapei, amontoados no chão, o que era incompreensível para Katow, já que logo ao lado havia um espaço grande e vazio. Ele então se levanta e começa a andar, machucado, até lá, mas todos o olham estupefado, dizem que ele é louco, até que um decide contar que "on met là ceux qui vont être torturé" ${ }^{254}$. Mas um dos homens, ao ser chutado, grita uma outra verdade, ainda mais cruel: a de que os comunistas não estão sendo torturados, mas queimados vivos em uma locomotiva.

Um oficial chega e leva Katow até aquele espaço vazio. Kyo também é para lá levado junto com três chineses, entre eles Lou You-shuen (o sócio de Hemmelrich na loja de discos), mas para aumentar ainda mais a tortura, eles teriam que escolher qual iria primeiro. E se em um primeiro momento os três restam estáticos, logo um se apresenta; e quando o guarda, menos de 5 minutos depois, pede para outro se apresentar, a briga é diferente: nenhum deseja ficar ali, esperando na extrema solidão, pela morte, e por isso os dois avançam juntos. Mas Lou é escolhido e cabe ao outro, sozinho, esperar, o que aumenta o desespero e faz sumir a coragem que a companhia dos outros lhe dava.

Kyo fecha os olhos e se deita, já na posição de um morto, pensando em May, no sacrifício desses homens, de como essas mortes poderiam permitir a sobrevida da Revolução. "Il mourrait parmi ceux avec qui il aurait voulu vivre; il mourrait, comme chacun de ces hommes couchés, pour avoir donné un sens à sa vie" 255 . Morrer naquele meio era mais fácil que morrer sozinho: a fraternidade viril sobressaia e tornava a

${ }^{252}$ IBIDEM - p. 727.

${ }^{253}$ IBIDEM - p. 728. A arte se mostra cada vez mais presenta na vida de Clappique. Naquele navio, fingindo ser o que não é, ele se nos revela um dos personagens mais farfelus de Malraux. O navio parte e Clappique consegue fugir, mesmo quando vê Ferral chegar ao cais e partir também para a França.

${ }^{254}$ IBIDEM - p. 730.

${ }^{255}$ IBIDEM - p. 735. 
morte menos dolorosa e/ou mais significativa. Diante da ameaça de ser logo morto, queimado (e portanto sofrer a morte, ser passivo), matar-se fica mais fácil e dá ainda mais força para a Revolução, que sobreviverá. Kyo engole o comprimido de cianureto que trazia consigo e logo morre.

"Katow, depuis la mort de Kyo - qui avait hatelé une minute au moins - se sentait rejeté à une solitude d'autant plus forte et plus douloureuse qu'il était entouré des siens" ${ }^{256}$. Se morrer, para Kyo, fora fácil por se sentir ligado aos que estavam ao seu lado, sua morte, para Katow, o jogou na extrema solidão, que se mostrava ainda mais forte porque ele não estava sozinho mas sim junto de vários homens que haviam lutado pelo mesmo ideal. No meio de pessoas iguais, sua solidão tornava-se mais angustiante.

Ao seu lado aparece Souen, que fora preso por esperar o carro de Tchang Kaïchek para jogar a bomba. Esse jovem chorava e com um camarada mostravam o terror de se verem queimados, de perceberem seus olhos serem queimados e então de nada mais perceberem. "Malgré la rumeur, malgré tous ces hommes qui avaient combattu comme lui, Kyo était seul, seul entre le corps de son ami mort et de ses deux compagnons épouvantés, seul entre ce mur et ce sifflet perdu dans la nuit. Mais un homme pouvait être plus fort que cette solitude et même, peut-être, que ce sifflet atroce" $^{257}$.

Katow pega seu cianureto e ao invés de tomá-lo e se entregar a essa solidão (se para Kyo morrer assim significava ainda agir, e deixar, desse modo, a Revolução ainda com esperança, para Katow ela significava desistir de tudo, entregar-se à solidão que era contrária a toda sua luta e vida), entrega-o a Souen. Ele corta a cápsula de cianureto em dois e passa, ne extrema escuridão, a um de ses camaradas. Mas logo ouve uma voz: "C'est perdu. Tombé"258.

Assim como a cena inicial do romance, na qual Tchen estava em um quarto para matar um homem, essa cena também é marcada pelo suspense e tempo cinematográfico (a tensão da perda do cianureto, a angústia dos dois homens que iriam tomá-lo e o perderam, e o desespero de Katow ao ver seu gesto desperdiçado são imagens bastante fortes e dramáticas). Os três começam a procurar, nervosos, o cianureto, e nessa confusão de corpos, escuridão e mãos, uma mão aperta a de Katow

\footnotetext{
${ }^{256}$ IBIDEM - p. 736.

${ }^{257}$ IBIDEM - p. 737.

${ }^{258}$ IBIDEM - p. 738.
} 
e lhe agradece, mesmo se nada encontrarem. Essa "pobre fraternidade sem rosto" emociona Katow, ainda mais quando eles encontram o cianureto, encontro esse que é simbolicamente denominado de "ressureição".

Os dois camaradas tomam o cianureto e Katow se sente abandonado. Oficiais chegam no meio da noite e procuram Kyo e Souen. Quando os encontram mortos, Katow confessa que deu cianureto a eles, o que faz com que eles levem-no ao trem. Katow caminha pesadamente, levado pelos guardas e logo a porta se fecha.

No dia seguinte ao da morte de Katow, Gisors fuma seu ópio na sala ao lado da qual o corpo de Kyo estava sendo vestido por May. E se Gisors vê nesse corpo o fim de sua esperanças, a não existência do mundo ("il était désormais rejeté à luimême. Le monde n'avait plus de sens, n'existait plus: l'immobilité sans retour, là, à côté de ce corps qui l'avait relié à l'univers, était comme un suicide de Dieu. Il n'avait attendu de Kyo ni réussite, ni même bonheur: mais que le monde fût sans Kyo..."259), May vê nele uma pergunta, um pedido que exige resposta, "une réponse au-délà de l'angoisse" 260 .

Se todo o livro se passou na China, nas cidades de Xangai e de Han-k'eou, na última parte somos levados para longe. Nada mais parece haver em Xangai. Tchang Kaï-chek chega na cidade e massacra os comunistas, matando Kyo e Katow - e com Tchen se matando e Clappique fugindo. Não há mais, ao menos no momento, como voltar a armar e entusiasmar os comunistas para uma nova insurreição. E sem isso, parece que o narrador não mais se interessa pelo destino da cidade. É em Paris, no mês de julho, que o narrador inicia a sétima e última parte do livro, e com Ferral em uma reunião com representantes do Banco da França e do consórcio para convencêlos a continuar investindo na China.

Ferral tenta convencê-los que se o consórcio ia mal, logo a revolução ia acabar, Tchang Kaï-chek se estabeleceria no poder e então o consórcio voltaria a lucrar muito (mesmo porque ele dera ajuda financeira ao general), mas a maioria discorda, acha que é incerto o destino do general, ou que o negócio era incerto ou ainda que fosse certo, seria algo a longo prazo que exigiria muito investimento. Ferral vê seu fracasso - ninguém se interessa pela manutenção do Consórcio e a reunião acaba sem que seus interesses predominem.

\footnotetext{
${ }^{259}$ IBIDEM - p. 742.

${ }^{260}$ IBIDEM - p. 741.
} 
E do fim da reunião em Paris o narrador vai até o Japão, até Kobe, onde May fora buscar Gisors (que estava na casa de Kama) para levá-lo até Moscou, onde seria professor no Instituto Sun Yat-sen. No caminho do porto até a casa de Kama, May lê uma carta de Peï, na qual ele fala também de Hemmelrich, que trabalhavam e esperavam pelo momento em que poderiam voltar a lutar.

Ao chegar na casa de Kama, encontra Gisors de kimono e sem mala, e logo descobre que ele não vai para Moscou. Aquela diferença, entrevista no modo como ambos viam a morte de Kyo, fica agora mais patente: enquanto May deseja vingar a morte de seu marido, sabendo que muitos não esqueceriam o quanto ele e outros sofreram, Gisors diz que "on ne se venge plus à mon âge..."261 e que era seu filho que o ligava ao mundo e ao comunismo, e que agora não há nem mesmo angústia nele: "depuis que Kyo est mort, il m'est indifférent de mourir. Je suis à la fois délivré (délivré!...) de la mort et de la vie"262.

Gisors dava aula de história da arte em Kobe (aula arrumada por Kama) e ali iria continuar. Esse homem se ligava ao comunismo porque era a vontade de seu filho; agora que ele morrera, não havia mais vontade para nada, nem mesmo para viver ou morrer. Lembrando do filho, olha May e pensa que nunca gostou da "mulher meio viril" que ela era e que só a considerava pelo amor (que ele achava intelectual demais) que Kyo tinha por ela. $\mathrm{O}$ que ele sempre procurou no amor foi a ternura, a contemplação - e não o conflito. Tanto no amor quanto na vida, Gisors tinha interesse no efeito do ópio que tanto fumava - a contemplação. E do mesmo modo como Clappique, Gisors fala à May que não há real, que há apenas mundos de contemplação no qual tudo é vão. O ópio é aquilo que melhor lhe permite justificar seu desejo de contemplação passiva e da repulsa da ação.

May fala da importância de agir, mas para Gisors nada mais tem sentido nem lhe interessa. O abraço que este dá ao se despedir dela não é o de compreensão (ele que sempre compreendera todos não é capaz de entender a mulher que não seja terna, passiva, como a sua era), mas uma tentativa de reavivar seu filho - ele a abraça do modo como Kyo a abraçava, mas isso não os une. Pelo contrário: nesse abraço a solidão de cada um fica mais forte e extrema, do mesmo modo como o abraço no fim de Les Conquérants e o olhar dos dois amigos em La Voie Royale.

\footnotetext{
${ }^{261}$ IBIDEM - p. 756.

${ }^{262}$ IBIDEM - p. 757.
} 
Os três livros terminam com momentos de uma fraternidade que explicita a solidão de cada um. E a morte é quem impera em todos: no destino próximo de Garine, no fato presente de Perken e no suicídio passado de Kyo.

Mas em La Condition Humaine há uma questão que não é colocada nos outros dois livros: o que os vivos devem fazer com a morte dos outros? O narrador de Les Conquérants não faz nada além de registrar a despedida e a certeza da morte de Garine; Claude, em La Voie Royale, até pensa em seus baixo-relevos, mas não ficamos sabendo o que ele fez e se obteve êxito. É só May quem diz que é preciso vingar a morte de Kyo e continuar a lutar pelo que ele queria. E é significativo que ela seja mulher, e que ela mesma tenha explicado o por quê: para uma mulher, o sofrimento lembra mais a vida que a morte, talvez por causa do parto, que é dor e vida ao mesmo tempo.

No entanto, se May despreza a passividade e contemplação de Gisors (enquanto ele contempla, outras pessoas como Katow continuam a ser queimadas vivas), se ela despreza a atitude de Gisors, esse despreza May pelo fato mesmo dela ser mulher, e pior: de ser uma mulher que é viril. Mulher, só podia ser admirada no pedestal de ternura e passividade, mas ela é uma mulher que nega sua "condição de mulher", e por isso não é compreendida nem mesmo por Gisors.

De todo modo, o livro novamente finda com um abraço, com um momento de fraternidade (agora não totalmente viril) que torna mais intenso não a união mas o isolamento. Gisors não compreende May nem ela a ele.

E esse isolamento e solidão são mostrados não apenas nessa cena: todos os personagens principais revelam momentos de extrema solidão, e de uma solidão quase sempre voltada para a morte (Tchen desde a primeira cena, na qual pela primeira vez mata um homem; Gisors com seu ópio, contemplação e negação da vida; Kyo no momento em que May diz que o traiu; Katow no momento final do livro, no qual entrega o cianureto aos companheiros e vê a morte de Kyo; Hemmelrich enquanto seu filho vivia e o prendia a tudo o que queria fazer pela Revolução - e mesmo os não revolucionários, Clappique e Ferral, sempre estão sozinhos e em busca de uma companhia que não é suficiente para ocultar a solidão).

Mesmo aqui, quando as questões revolucionárias estão tão presentes, quando os personagens se interessam mais por suas ações, a solidão impera e os joga silenciosamente na luta metafísica contra a morte. Mesmo Kyo, lutando pela 
dignidade dos seus, achando que apenas o comunismo é capaz de fornecer essa dignidade, sente-se muitas vezes só, sente os outros homens como juízes que o olham e o escutam pelos ouvidos, nunca conhecendo o som de sua garganta - e até May, no momento da traição, se torna um "outro".

No entanto, como já começamos a dizer da última cena do livro, há aqui uma questão que não é posta nos outros livros: a da continuidade da ação, da importância da concretude histórica. Se nos outros livros o fim era determinado pela morte próxima ou pela morte presente, em La Condition Humaine as ações continuam após a morte.

Não apenas os vivos pensam nessa continuidade - os que vão morrer também querem fazer de sua morte motivo para os outros prosseguirem. Tchen pede para Peï escrever sobre seu gesto para que outros o entendam e o sigam (a vida de Peï e a escrita são necessárias para garantir o prosseguimento de seus ideais), Kyo se mata pensando que isso ainda é uma ação e não uma submissão, fazendo, assim, com que os outros consigam ver mesmo na morte um ato de coragem; e Katow entrega os cianuretos aos companheiros para mostrar que a fraternidade pode ser maior que a solidão, que a morte.

Mesmo diante da morte certa, não há a determinação do fracasso, da derrota total. A morte física, aqui, não implica a morte das esperanças. E os que vivem compreendem esse "exemplo" que os mortos quiseram dar. À exceção de Gisors, que se entregara de vez à contemplação após a morte de seu filho, Hemmelrich, Peï e May continuam a trabalhar e a preparar uma nova revolução. Eles desejam dar continuidade à ação dos mortos, desejam continuar o que foi momentaneamente interrompido pela morte.

E se as críticas de Brasillach (de que o livro mostra um orgulho desesperado) e a de Ilya Ehrenbourg de que o livro mostra heróis como românticos exaltados, sendo a revolução uma história de um grupo de conquistadores ${ }^{263}$, são corretas - se $L a$ Condition Humaine mostra, como os outros livros, uma relação elitista e estrangeira dos líderes com a revolução, e uma relação que revela o orgulho desesperado dos heróis, não podemos dizer, no entanto, que a concretude história se anula totalmente, tal como em Les Conquérants e La Voie Royale. De um certo modo, a sorte da

${ }^{263}$ Cf. MALRAUX. Oeuvres Complètes - Notice. 
Revolução importa mais que nos outros livros, já que os personagens que morreram desejam sua continuação e os que sobreviveram pretendem continuá-la.

A questão da história, da sorte das ações, ganha um peso maior nesse livro, e consegue, assim, impor-se, não se anular perante a questão metafísica, a qual continua. A dignidade e fraternidade não chegam a anular a solidão e o confronto com a morte, mas quebram a mediocridade ${ }^{264}$, convivem junto com as questões metafísicas.

Se nos romances anteriores a historicidade era anulada pela metafísica, se esta relegava àquela a uma indiferença total, agora ambas convivem num convívio tenso, no qual às vezes uma se sobressai e às vezes outra. Há uma oscilação no modo como os personagens lidam com a história: se todos os revolucionários se sentem muitas vezes extremamente solitários no confronto com a morte, eles também se mostram, principalmente quando o duelo final diante do destino absurdo está próximo, preocupados com a continuação da Revolução: mesmo Tchen, o que se revela mais distante de todos os revolucionários em relação às questões concretas, diz em alguns momentos que "ao menos o proletário era a forma de sua esperança", "ao menos o combate era a ligação mais forte" (o que, se é compensação, é também preocupação com os motivos e justificativas de suas ações) e antes de se jogar com uma bomba em um carro, pede que outro testemunhe e escreva sobre seu ato (se seu interesse fosse apenas sua luta solitária contra a morte, por que comunicar aos outros seu ato?).

Mesmo o mais solitário dos revolucionários mostra momentos em que deseja se unir ao proletariado e comunicar sua ação, esperando que outros a repitam e a entendam. Há, portanto, uma oscilação no modo como os personagens vêem a história: ora como símbolo desimportante da luta contra o destino, ora como importância real e concreta para a vida de todos.

Assim, não podemos mais dizer que a história se anula diante das questões metafísicas, como acontecia nos livros anteriores: em La Condition humaine ambas convivem sem harmonia, num instável equilíbrio. Talvez apenas May esboce a continuidade entre uma e outra concepção de história ao dizer que o sofrimento (para as mulheres) lembra mais a vida que a morte, que é do e no sofrimento (no parto) que a vida nasce, mostrando, desse modo, que há um imbricamento entre dor e alegria, morte e vida, sofrimento solitário e ação coletiva - mas essa personagem não é

${ }^{264}$ Cf. MOUNIER, E. A esperança dos desesperados. 
compreendida por ninguém (nem mesmo por Gisors, que compreende todos os personagens do romance).

Suas aparições no romance são menores do que a de Clappique, um personagem praticamente saído dos contos de juventude de Malraux: ele é o personagem bufão, que vive a criar histórias. A imaginação para ele é fundamental, mais até do que a própria vida. Seu desejo é o de negar o mundo e a si mesmo, e para isso recorre ao farfelu tão usado nos contos anteriores. E é justamente ele que mais fala da arte: o imaginário, para Clappique, é não apenas um modo de fazer arte mas principalmente de fazer a vida, e fazer a vida é fugir dela, é negá-la.

Novamente a arte aparece nos livros de Malraux de modo a representar uma fuga em relação ao caos e tirania do real, dos acontecimentos. Clappique se refugia no farfelu, finge a todo momento ser outro e os personagens que inventa tornam-se ele mesmo à medida que outros olham e acreditam neles, sendo essa artimanha não um meio de fazer arte mas principalmente um meio de viver.

A vida aparece indissociável da arte, não porque esta revela de uma maneira mais profunda aquela, mas sim porque a nega, a transcende não para se voltar a ela mas para permitir a construção de um novo mundo no qual o sentido voltaria a habitálo e no qual uma nova noção de homem seria reinventada, combatendo, assim, o caos desse mundo que não governamos mas que não é mais governado por Deus.

Mas se há Clappique para mostrar que a arte, frente a uma relação alheia e indiferente com a história, continua a ser fuga, há também uma frase de Tchen que revela que a escrita pode ter outra função: a de fazer os outros compreenderem sua ação e de estimular sua continuação. É certo que talvez essa escrita seja mais jornalística que imaginária, mas ela é escrita e visa também uma certa perpetuação, não mais em relação ao conflito com a morte, mas em relação às ações necessárias para continuar a Revolução ou qualquer outra modificação real.

E são esses papéis que a arte poderia exercer nesse mundo no qual a história ainda se encontra dissociada da metafísica: ou ela se volta inteiramente para a concretude do real ou ela se abstrai totalmente no mundo imaginário e metafísico. $\mathrm{Na}$ medida em que os personagens principais do romance ainda conservam um paralelismo entre história e metafísica, na medida em que ambas existem (e não mais da forma como vimos nos outros livros, com a metafísica anulando a história e tornando-a indiferente) mas sem relacionar-se diretamente, a arte não poderia 
apresentar-se como sendo ao mesmo tempo metafísica e história. Ela aparece ora como um meio de alcançar a eternidade, ora como voltada exclusivamente para o real e seus problemas.

Nos três livros de Malraux que analisamos até aqui, Les Conquérants, La Voie Royale e La Condition Humaine, a arte aparece (embora nesse último livro não mais de forma exclusiva: a arte adquire também uma outra função) como fuga e abstração da história, como um modo de negá-la para tentar encontrar um sentido no mundo desordenado - mas nesse movimento de negação, o ato mesmo de significar o mundo torna-se sem sentido, e a abstração passa a imperar.

A única ética que essa arte possibilitaria é uma ética da renúncia, da abstração e fuga: se não há mais Deus que nos tranqüilize e garanta as justificativas de nossos atos, se para os personagens mergulhar nesse mundo imundo é impossível (apenas os personagens de La Condition Humaine fazem isso, todos os outros agem com extrema indiferença), só resta tentar encontrar uma nova ordem por meio de uma ação e de uma arte que neguem o caos e tentem construir uma nova noção de homem. O que todos os personagens buscam é uma garantia metafísica que lhes foi arrancada com a morte de Deus, mas não é no concreto que eles a procuram, é na abstração do irreal, no imaginário.

Mesmo a ação, que aparece em todos os livros, está quase sempre desvinculada das questões históricas, aparece como semelhante à criação artística, com um caráter imaginário, irreal, isolado dos motivos e conseqüências reais. Apenas em La Condition Humaine ela aparece como uma maneira de garantir a continuidade histórica, que passa a ser importante para todos os personagens.

Enquanto a história está totalmente submetida à metafísica (caso de Les Conquérants e La Voie Royale), só se pode pensar em uma ação que vise a metafísica, que se importe com a luta incessante e sempre vã do homem contra seu destino absurdo, tornando indiferente qualquer problema histórico. Mas quando a história passa a ter sua importância, quando as questões de continuidade deixam de ser privilégio da metafísica para alcançar a história (caso de La Condition Humaine), a ação e a arte passam a ter uma outra função: a de deixar cicatrizes reais no mundo e de buscar a continuidade do humano, de tentar fazer com que as questões concretas não findem com a morte biológica. A arte e a ação continuam a buscar uma perpetuação, mas agora isso se dá no próprio real, e não mais por meio da fuga dele. 


\section{Conclusão}

Nesses três livros de Malraux por nós analisados vimos que muitos dos temas já presentes nos contos de juventude tornam-se mais presentes: os heróis dos três romances são caracterizados como aqueles que souberam se desvencilhar da moral burguesa, que se revoltam contra ela e buscam, de outro modo e em outro lugar (sempre no Oriente), afirmar seu modo de viver e enfrentar a morte e a submissão. E nessa luta contra o destino, eles se ligam, de forma mais ou menos forte, às questões históricas: Garine na revolta de Cantão em 1925, Perken nas tribos que tentam resistir à colonização (embora isso apareça de modo fraco) e Kyo e outros na revolta em Xangai em 1927.

Esses heróis se encontram, diferentemente dos personagens dos contos de juventude, imersos na historicidade - e não porque foram nelas jogados, mas porque a procuram. Garine, Claude e Perken e muitos dos revolucionários de La Condition humaine são europeus que viajam para o Oriente sabendo das revoltas que ali ocorriam, e que se inserem nessa luta ao menos para confrontar o espírito ocidental burguês de onde saíram e que não suportam.

Nossos personagens procuram, portanto, a história, fogem desse mundo tão limpo e organizado que é a Europa para entrarem em florestas fechadas e desconhecidas, em guerrilhas urbanas nas cidades divididas geográfica e ideologicamente. Da Europa mostrada sempre como clareza, luz, sol, esses personagens entram em uma Indochina que impõe aos sentidos excessivos e sufocantes barulhos, cheiros e luzes.

Todos vão ao encontro dos conflitos desconhecidos e desejados, todos querem agir, mostrar sua revolta. E se antes Malraux mostrava essas mesmas questões de modo farfelu, apelando para o uso excessivo do imaginário, com personagens e cenários emprestados de um cubismo literário, agora, a partir de Les Conquérants, ele o faz de modo mais realista. Há uma queda brusca na historicidade, no chão dos acontecimentos - seus personagens não mais se envolvem em questões fantasiosas como a serpente Clave de Sol que pedia virgens à cidade em troca de paz, mas em questões reais e urgentes: as revoltas preparadas e realizadas na China, o colonialismo, a interferência da URSS nas revoltas e nos PC de outros países. 
Um dos grandes méritos de Malraux, e talvez foi o que o fez tão importante para o cenário da literatura francesa do final de 20 e em toda a década de 30 , foi justamente colocar a história na ficção. Narrar as revoltas comunistas chinesas pouco tempo depois delas terem acontecido e fazer referência (mesmo que de forma não enfática) aos problemas da colonização francesa antes mesmo que eles estourassem, rendeu a Malraux reconhecimento literário e fama de aventureiro revolucionário (imagem essa que, segundo os comentadores, ele quis alimentar).

É essa visão importante da história que Sartre reconhece como sendo um grande mérito de Malraux. Enquanto nessa década de 20, década de medo de um novo assalto da história, os europeus evitavam pensar em novas guerras e elegiam uma paz atemporal como tema preferido, Malraux preferia retratar as guerras que persistiam e que eram ignoradas.

Em Que é a literatura? (escrito em 1946), Sartre diz que Malraux, numa época anterior à descoberta da historicidade pela maioria dos franceses, já escrevia seus romances imersos na concretude histórica. Em uma época na qual o clima literário tendia ao platonismo, Malraux revelou a história. "Enquanto a nós foi necessário, para nos descobrirmos, a urgência e a realidade física de um conflito, Malraux teve o imenso mérito de reconhecer, desde a sua primeira obra, que estávamos em guerra e era preciso fazer uma literatura de guerra, num momento em que os surrealistas e mesmo Drieu la Rochelle se consagravam a uma literatura de paz"265.

É esse peso que Malraux soube dar à história no momento em que muitos a queriam ausente que Maria Teresa de Freitas também ressalta como mérito do autor: no entre-guerras, a literatura não é engajada politicamente, fala quase sempre de paz e de coisas pitorescas. Malraux foi uma das grandes exceções dessa época. Em seus romances, há, para a autora, atualidade (não fala do passado, mas dos acontecimentos presentes), cosmopolitismo (contra o nacionalismo francês, vai procurar seus temas onde os problemas históricos se colocam) e a história torna-se o tema mesmo dos romances.

E por ter ousado dizer o nome da história e da guerra e de forma também ousada (com fragmentação dos pontos de vista), Malraux passa a ser bastante reconhecido desde a publicação de Les Conquérants em 1928. Depois das aventuras

${ }^{265}$ SARTRE. Que é a literatura?, p. 227, nota 9. 
vividas na Indochina e da escrita do primeiro romance, Malraux passa a ser bastante respeitado, tanto literária quanto politicamente.

E na medida em que escolheu narrar questões atuais, seus romances provocaram discussões e debates, principalmente relacionados ao comunismo na URSS e ao papel desse país em relação aos Partidos Comunistas de outros países. Até mesmo Trotsky escreveu carta a Malraux para comentar sobre Borodine e o papel do revolucionário bolchevique profissional, e o autor dos romances a ele respondeu, replicando que seu tema não era só a revolução chinesa mas a relação do indivíduo com a revolução.

Houve, na França e nos meios comunistas, leituras e discussões em volta principalmente de Les Conquérants e La Condition Humaine, e que, por isso, mostravam-se históricos em um duplo sentido: tanto por narrarem temas históricos e confrontos quando a literatura francesa só falava de paz quanto por suscitarem questões e discussões sobre o comunismo e o papel do PC.

Mas, se por um lado, a história passa a ser o tema e o cenário dos três romances, ela não é propriamente vivida pelos personagens. Parece haver uma ambigüidade no modo como Malraux vê e narra a história: se se torna o palco de suas narrações, aqueles que nela atuam parecem não dar nenhuma importância a ela.

Garine, em Les Conquérants, vai até Cantão para participar da revolução apenas para ser contra a burguesia da qual saíra. É o próprio Garine quem confessa se ligar aos comunistas apenas porque esses são derrotados, e que, a partir do momento em que os pobres tomarem o poder, vencerem, eles se tornarão tão abjetos quanto os burgueses.

Ele é indiferente aos resultados concretos de suas ações. Se essas importam, não é porque trarão determinada mudança mas porque elas simbolizam a luta contra a força externa e absurda que é o destino. "Mon action me rend aboulique à l'égard de tout ce qui n'est pas elle, à commencer par ses résultats" ${ }^{266}$. Garine vai em busca da história mas faz dela não a luta concreta contra a opressão e a busca da liberdade mas o símbolo de sua luta solitária, vã e perdida por princípio contra a morte.

E se o livro termina com a vitória social, com as tropas de Tchang Kaï-chek derrotando os generais do norte e com o decreto (tão desejado por Garine) que

${ }^{266}$ MALRAUX. "Les Conquérants" In Oeuvres Complètes - p. 250. 
determina o fechamento do porto de Hongkong aprovado, não é a sensação de vitória que fica no leitor e nem mesmo para Garine: o que sobressai, ainda mais se contrastado com a alegria dos outros, é a doença do personagem principal e sua morte próxima, o que acentua ainda mais seu isolamento, sua incapacidade de se comunicar. No cenário de despedida e morte, a vitória social não tem sentido algum, serve, ao contrário, para tornar ainda mais triste e trágico o destino de um de seus líderes.

Les Conquérants mostra, assim, uma concepção de vida que se caracteriza pelo confronto constante e vão contra o destino humano no palco indiferente da história. E o mesmo pode ser dito, em linhas gerais, de La voie Royale, publicado dois anos depois de Les Conquérants, em 1930. Aqui Perken, também europeu, entra na selva cambojana para roubar estátuas de templos abandonados e para procurar um homem que desaparecera. Ele se mostra indiferente, hostil em relação aos valores burgueses estabelecidos, e principalmente obcecado pela morte.

Perken se revolta com a vida burguesa, que prega a submissão e o respeito à ordem, e passa a viver na selva cambojana, ajudando (sempre de modo superior, como um líder, papel esse que é muito importante nas obras de Malraux) as tribos a se defenderem contra os colonizadores. Mas, assim como Garine, Perken não se sente ligado ao que defende, o problema da colonização não é escolhido por ser a luta contra a opressão mas sim porque ela é o símbolo de uma luta mais importante, a luta contra os valores burgueses e o destino inevitável.

Desse modo, La voie Royale nos revela as mesmas questões já vistas em Les Conquérants: a do herói solitário que busca em conflitos históricos ganhar ao menos temporária e simbolicamente a luta necessária e vã contra o destino humano, a morte, que novamente aparece como certa ao final do livro.

Porém, e é o próprio Malraux quem o diz, Garine parece não ser tão indiferente à sorte da revolução chinesa, já que arriscou sua vida por ela. E o mesmo podemos dizer de Perken: ambos escolheram as lutas que queriam empreender, e elas estavam sempre ligadas, de certa forma, à luta contra a dominação burguesa e européia.

Mas se nos parece certo que há algum motivo para escolher esses conflitos e não outros, em nenhum momento, nem na fala dos personagens, nem em suas ações, nem no modo como se relacionam com os companheiros, Garine e Perken se mostram ligados aos motivos e conseqüências de suas ações. Não é possível encontrar, em Les Conquérants e em La voie Royale, nenhuma ligação dos personagens principais com a 
concretude histórica. Embora eles ajam, eles o fazem com indiferença: só a forma da ação lhes interessa e não seu conteúdo.

Mas não podemos dizer que em La Condition Humaine, publicado em 1933, ocorra o mesmo.

Embora todos os personagens principais sejam europeus (Tchen e Kyo são chineses, mas suas criações são protestante e japonesa), embora todos se mostrem solitários em vários momentos (Tchen já na primeira cena, Kyo ao saber que sua mulher o traíra, Katow diante da morte de Kyo, Hemmelrich com seu filho doente que o impede de agir, Clappique em seu mundo farfelu, Gisors com seu ópio, Ferral diante da vingança de uma mulher), há uma maior ligação desses personagens com os acontecimentos revolucionários de Xangai em 1927.

Com exceção talvez de Clappique (indiferente a tudo que não seja seu mundo fantasticamente imaginado), todos se importam com as conseqüências da Revolução e de seus atos: seja Gisors que deseja a vitória de seu filho Kyo, seja esse, que quer dar vida digna e justa aos seus, seja Ferral que torce pela vitória de Tchang Kaï-chek para que seus negócios continuem a dar lucro; esses personagens principais têm uma causa e um desejo. Eles não se encontram indiferentes, alheios: eles agem e esperam modificar algo.

Não estamos mais falando de uma crítica e revolta em relação aos valores burgueses que se dá de forma apenas negativa, destrutiva, sem que a construção de outra coisa seja pensada. Em La Condition Humaine a ação adquire um peso significativo e não mais somente simbólico. E mesmo Tchen, o personagem que mais mostra sua solidão e indiferença em relação aos outros, pensa na continuidade de seu ato, na necessidade dos outros entenderem o que ele fez.

As questões do enfrentamento necessário e vão contra o inevitável destino humano, a morte, e da solidão à qual os heróis estão destinados continuam fortemente presentes em La Condition Humaine, mas nesse terceiro romance os personagens principais realmente se inserem na concretude histórica e se ainda desejam enfrentar o absurdo da morte, aprenderam que só é possível fazê-lo na história e lutando por motivos e modificações concretas.

É por isso que, se a questão do confronto com a morte permanece, a ela se acrescenta a preocupação com a conseqüência e continuação da ação. Se a morte é inevitável, aqui ela não torna a ação indiferente; ao contrário, a ação passa a ser o 
instrumento que permite a continuidade, a permanência. A história concreta não mais se anula diante da questão metafísica do homem contra a morte, a qual permanece.

E se quase todos os personagens principais morrem, como acontecia nos dois livros anteriores, todos têm a preocupação de fazer de sua morte motivo e exemplo para que outros ajam, o que não vimos nos outros livros.

E não só os que morrem se colocam essa questão como também alguns personagens que sobrevivem a fazem: se ainda temos personagens como Gisors para quem a ação, depois da morte do filho, perde todo o sentido, surgem personagens como May e Hemmelrich, que continuam a agir e se perguntar o que devem fazer com a morte dos outros.

Assim, vemos que enquanto em Les Conquérants e La Voie Royale a história é importante mas não é realmente vivenciada por seus personagens principais (na medida em que agem mas não se ligam às conseqüências de suas ações nem às causas que defendem, sendo indiferentes a tudo que não o próprio ato de agir), em $L a$ Condition Humaine podemos dizer que a história passa a fazer parte não só do cenário como também das preocupações dos personagens, deixando, assim, de ser colocada em segundo plano.

Se desde a publicação de Les Conquérants em 1928 Malraux é celebrado por ter evocado os temas da guerra e da história num momento em que os europeus só pensavam em uma paz ahistórica, pensamos que apenas com La Condition Humaine o autor faz a história não ser apenas cenário indiferente no qual ocorrem os acontecimentos mas também e principalmente dizer respeito às modificações necessárias e concretas.

Mas se a história é importante nesses três livros (mesmo que nãõ vivida do mesmo modo pelos personagens), ressaltando, assim, as questões éticas que já apareciam nos contos de juventude de maneira implícita, oculta pelo excesso de fantasia, a arte, que era tão presente nesses contos, perde e muito sua importância nos romances. Enquanto nos contos a arte sempre aparecia, não apenas nos discursos dos personagens mas também e principalmente como instrumento de luta, nos romances, realistas na descrição de homens imersos em guerras, ela quase desaparece.

Em Les Conquérants há poucas e indiretas referências à arte. Se no início o narrador nos revela que Garine gostava apenas das "Memórias", mostrando assim que 
os grandes atos estão acima da ficção, no fim do livro é o próprio Garine que fala sobre a criação, dando-lhe uma grande importância: segundo ele, o único modo de se defender do absurdo é criando. Embora ele não esteja falando explicitamente da criação artística (já que se refere depois a edificar homens), podemos estender esse papel de defesa também à arte, já que ela também se encontra no plano da criação.

E se for assim, a arte seria então um dos meios de se defender da morte, um meio de garantir, de certa forma, a permanência mesmo depois do fim. E é exatamente a isso que Garine faz menção ao comentar sobre Michelângelo em um trecho que foi retirado por Malraux ao publicar o livro, que apesar de tudo, o pintor venceu, conseguiu garantir o sucesso apesar da derrota que parece ter sido sua vida.

E é essa mesma concepção da arte como defesa, como fuga e possibilidade de constituir uma perpetuação frente à morte que vemos também em La Voie Royale. Nesse segundo romance a arte aparece muito pouco (e trechos que se referem a ela também foram eliminados pelo autor) e novamente apenas como discurso. Claude, no momento em que vai ao Instituto Francês para retirar os documentos para sua viagem, conversa com o diretor sobre o papel dos museus e da arte, pensando que "ce qui m'attache lá c'est l'acharnement des hommes à se défendre contre leur mort par cette éternité cahotée" ${ }^{267}$.

A arte aparece como defesa do homem contra sua morte, é uma espécie de eternidade caótica que permite simbolizar a permanência humana através do tempo. $\mathrm{O}$ homem, por meio da arte, permite que povos futuros compreendam o seu presente, garantindo, assim, a permanência, uma certa imortalidade.

Nesses dois livros a arte, nos poucos momentos em que aparece, tem o valor de uma defesa simbólica contra a Morte. Na medida em que os personagens não mergulham efetivamente na história, em que o importante é vencer o absurdo destino humano, tanto a ação quanto a arte se constituem para os personagens como defesa simbólica e não efetiva.

Mas em La Condition Humaine essa relação entre arte e história, estética e ética, modifica-se. A história, como já vimos, é realmente inserida no romance e não apenas como preocupação metafísica mas também como problema real e concreto.

${ }^{267}$ MALRAUX. "La Voie Royale" In Oeuvres Complètes - p. 398. 
Temos, nesse romance, a convivência das duas lutas, a metafísica, do homem contra seu destino (que dominou nos livros anteriores), e a concreta, do homem contra a opressão real (que surge efetivamente apenas nesse livro); e a arte oscila agora entre uma e outra luta. Em ambas as concepções, na metafísica e na concreta, a arte continua a ser defesa, mas o modo como essa defesa é pensada é diferente.

Para o personagem Clappique, o homem farfelu do romance, parecido com os personagens dos contos de juventude, a imaginação é aquilo que permite se refugiar do mundo concreto cruel, inventar um outro mundo fantástico no qual é possível vencer, revelando assim, uma concepção idealista e abstrata da arte, presente também em Les Conquérants e em La Voie Royale. Nesse caso, a arte é defesa porque simboliza, abstratamente, a vitória humana contra a morte. Por meio da fuga, do excesso de fantasias e imaginação, a arte indica uma eternidade que não pode ser buscada concretamente.

Mas outra concepção de defesa, agora mais efetiva e concreta, de acordo com as questões históricas que surgem, aparece em La Condition Humaine.

Tchen, o personagem que se torna terrorista a partir da primeira cena, quando mata pela primeira vez, que mais e melhor mostra sua solidão em meio à luta comum que é a Revolução, revela uma preocupação com a continuidade de sua ação, o que poderia ser garantida por meio da escrita. Antes de se jogar com uma bomba no carro de Tchang Kaï-chek, pede para que Peï testemunhe o atentado e escreva sobre ele, transmitindo o sentido de sua ação e possibilitando que outros a repitam, perpetuando, assim, seu ato.

Para que a ação seja efetivamente perpetuada é necessário não só agir mas transmitir a ação por meio da escrita. Se a arte pode ser farfelu (revelando uma defesa simbólica contra a morte), ela pode também ser realista, referir-se a fatos e personagens concretos (constituindo-se, assim, como uma defesa concreta e efetiva contra a morte).

A arte parece se mostrar, nesses três livros por nós analisados, como meio de se defender do destino absurdo, da morte, como meio de perpetuar a ação e a criação do homem, de eternizar seus feitos.

Mas se essa defesa se dá, nos dois primeiros livros, de maneira exclusivamente formal e simbólica, sem relação com a concretude histórica (e nem poderia ter, já que a história é aqui desprezada e anulada perante a luta contra o destino), em La 
Condition Humaine aparece uma nova maneira de se pensar a defesa realizada pela arte, relacionada com o novo sentido que a história adquire.

Nesse terceiro romance, a arte ora aparece como defesa abstrata e simbólica, semelhante aos outros romances e aos contos de juventude (e essa concepção permanece porque a questão do confronto solitário e metafísico contra a morte continua essencial), ora como defesa concreta e efetiva, que permitiria que as ações realizadas em prol da revolução se perpetuassem.

Aqui parte dos personagens se importa com as questões nas quais se envolve, luta e tem interesse em ganhar também a luta concreta contra a opressão - a história deixa de ser só o símbolo da luta metafísica contra a morte para se tornar também tema e conteúdo para os personagens, para se tornar efetivamente importante. E para esses personagens, a arte não poderia ser apenas defesa simbólica: ela passa a ser também defesa concreta e efetiva, meio de perpetuar a ação humana contra a opressão real em busca da liberdade concreta.

De todo modo, seja defesa simbólica ou concreta, a arte sempre aparece nos romances de Malraux relacionada direta e estreitamente à concepção de história. Há uma relação intrínseca entre o modo como narra o papel da arte e da ação, o modo como concebe a estética e a ética: o modo como se deve pensar o papel da arte está, nos romances de Malraux, sempre vinculado à concepção histórica apresentada. E se podemos dizer que a arte é sempre vista como defesa, como meio de garantir a eternidade dos atos humanos, esse papel adquire diferentes sentidos de acordo como a história é vista: é alienante enquanto a história é anulada em prol do conflito metafísico do homem contra a morte e é crítico quando a história passa a ser considerada e vivenciada pelos personagens, servindo, assim, para condenar e explicitar a dominação e a opressão.

Assim, se a arte é sempre defesa - concepção essa que aparece em todos os contos e romances de Malraux e que coincidem com seus escritos sobre a arte, essa defesa pode ser alienante ou crítica, conforme a maneira pela qual a história aparece e é vivida pelos personagens, revelando, desse modo, que há, para Malraux, uma vinculação estreita entre ética e estética, devendo uma ser pensada junto com a outra e nunca de modo separado, isolado. 


\section{CAPÍTULO TRÊS}

\section{OS ROMANCES DE SARTRE}

a) A Idade da Razão

b) Sursis

c) Com a Morte na Alma 


\section{OS CAMINHOS DA LIBERDADE DE SARTRE}

Os Caminhos da Liberdade foram escritos durantes a década de 40, bem depois da publicação dos romances de Malraux que analisamos anteriormente (final da década de 20 e começo de 30). Embora ambos começassem a escrever contos mais ou menos no mesmo período, Malraux escreveu romances e foi reconhecido no mundo literário bem antes de Sartre, que só passou a ser reconhecido no meio da década de 30, com a publicação de $A$ Náusea e $O$ Muro.

E se escolhemos os três romances iniciais de Malraux, não vamos analisar o romance de estréia de Sartre, mas sim sua trilogia, que se assim se tornou, não foi porque estava previsto: inicialmente seriam apenas dois livros, que se transformaram em três e quase em quatro, cinco e até mesmo seis (o tempo todo Sartre dizia pensar em continuações e chegou a escrever trechos do quarto volume e a criar histórias para o quinto e sexto volumes). Se os romances foram pensados como continuação (ao contrário dos romances de Malraux, que são histórias diversas de diferentes personagens, mas que agrupamos por ter a mesma temática e principalmente a mesma localização), eles não foram pensados como trilogia.

Já em 1938 Sartre escrevia seu romance, quando a guerra o pegou de surpresa e tanto a escrita quanto o conteúdo do livro sofreram bastante modificação. Mobilizado numa "drôle de guerre", Sartre continua a escrever o primeiro tomo, mas só o publica após o fim da guerra, em 1945, juntamente com o segundo volume, Sursis, escrito de 1941 a 1944. O terceiro volume, Com a Morte na Alma, será publicado alguns anos depois, em 1949.

A Idade da Razão, Sursis e Com a Morte na Alma contam a história de alguns personagens entre 1938 e 1940, quando os franceses passam das preocupações cotidianas à espera e vivência de uma guerra. Se muitos personagens aparecem, principalmente em Sursis, livro totalmente desfragmentado, apenas alguns surgem nos três romances, e desses sem dúvida alguma Mathieu, professor de filosofia que não aparece em sua profissão, é o principal... é a maneira encontrada por Sartre para criar um personagem que seja ao mesmo tempo burguês e intelectual e que esteja à margem da sociedade. 
São suas preocupações e problemas que acompanhamos nos três romances: desde a questão mais pessoal de ter a amante grávida e querer o aborto até a questão mais ampla de estar como soldado em meio a uma guerra mundial, é Mathieu que acompanhamos nos "caminhos da liberdade" (e não é por acaso que seu sobrenome seja Delarue, "da rua", aquele que é comum, igual aos outros e que caminha). E se a guerra aparece como ameaça em Sursis e como realidade em Com a morte na alma, não é porque os heróis procuram por algo excepcional, grandioso (como são os heróis de Malraux que viajam em busca de aventuras e guerras), mas porque "simplesmente" a guerra aparece na França e quase não se pode fugir dela. Não há em Sartre o gosto pelo heróico, pelas lutas e guerras; ao contrário: seu gosto é pelas aventuras cotidianas, simples, com preocupações banais mas tão reais como a falta de dinheiro.

Se compararmos com os contos de juventude analisados no primeiro capítulo, podemos dizer que não há uma mudança tão radical como vimos em relação à trajetória de Malraux, que começara escrevendo contos bastante imaginários, cubistas e depois escreve romances muito próximos aos acontecimentos reais, com personagens humanos em guerras como a da Indochina. Em Sartre não existe uma grande distinção entre os contos de juventude e os romances de maturidade: nos dois casos estamos diante de narrações que falam do dia-a-dia de personagens.

Embora o estilo seja diferente (não se trata mais de contos mas de romances), embora Sartre mostre mais preocupação com as palavras e modo de narração, com a técnica do romance (a ponto de ler e analisar nessa época Faulkner, Dos Passos, Hemingway, Virgínia Woolf); há uma certa continuidade em relação aos contos de juventude: não há rompimentos bruscos e radicais, continuamos a ver personagens mergulhados na história do dia-a-dia.

O que mais se modifica é a presença da guerra a partir de Sursis, o que faz as questões individuais não perderem o valor mas terem a importância diminuída, serem em parte causadas, paralisadas ou resolvidas por causa dessa guerra, questão comum a todos os europeus dessa época. Se em junho de 1938 (época em que $A$ idade da razão se passa) ainda se pode viver tranqüilamente em Paris e pensar apenas nos problemas pessoais (mesmo já tendo a Guerra da Espanha e refugiados judeus, não é algo que atinja diretamente alguns franceses, como Mathieu) ${ }^{268}$, em setembro do mesmo ano já

\footnotetext{
${ }^{268}$ Se Malraux já mostrava a presença da história em 1933, ano em que Hitler sobe ao poder, Sartre demora mais cinco anos para mostrar essa mesma presença.
} 
se torna impossível ignorar a guerra que ameaçava estourar - se a guerra aparece nesses romances é por isso, é porque se tornara o cotidiano para esses homens e não porque é algo grandioso e excepcional.

A história surge portanto em Sursis, e faz desse romance não propriamente um romance sobre Mathieu, mas sobre muitos personagens que vivem todos, mesmo que de forma bastante distinta, uma mesma guerra. Se Mathieu ainda continua com importância, não é unicamente sua história que é narrada: é a história que surge em ato pelos romances de Sartre. Antes mesmo dela surgir como tema explícito em sua teoria, a história que engloba todos os europeus, fazendo-os não mais ignorá-la, já surge em Sursis. O surgimento da guerra como horizonte impede que a narração continue centrada apenas em Mathieu - outros personagens surgem com importância e é a relação de todos com a história que passa a interessar ao autor.

É o cotidiano com seus problemas, silêncios e conflitos que interessa a Sartre e é nele que as questões tão essenciais para sua compreensão da realidade humana são colocadas, como a da liberdade, do olhar, do engajamento e da história. De certa forma já presentes nos contos de juventude, esses temas aparecem com força na trilogia - e a guerra, se torna algumas questões um tanto esquecidas, torna outras mais urgentes.

Mas se as semelhanças são grandes tanto em relação à forma quanto em relação aos temas, não podemos esquecer que existem distinções e que se a guerra aparece por se tornar cotidiana, ela é um cotidiano que destrói qualquer outro cotidiano, que submete qualquer questão pessoal a essa questão maior. E é por meio dessas modificações (que podem ser vistas até mesmo dentro da trilogia, comparando o modo de agir de alguns personagens no primeiro e terceiro volume) que pretendemos compreender se a relação que Sartre estabelece entre a estética e a ética permanece semelhante aos contos de juventude.

Tomando o cuidado de não passarmos diretamente do conteúdo moral fictício para um código de ética real (como já dissemos ao analisar os romances de Malraux, colocar o real na ficção traz o problema de existir uma ética no romance, mas não se pode ignorar que essa ética está ali justamente como romance e não como realidade), tentaremos analisar os três romances de Sartre para então compreendermos o papel que a arte teria nesse mundo e como essa teoria da arte leva a uma certa ética. Sem podermos realizar análises tão detalhadas como fizemos com os contos (o tamanho de 
um romance torna isso impossível), vejamos então quais são as questões principais de cada romance e como os personagens lidam com elas; para então compará-las com as noções de arte para Sartre, e relacioná-la com uma ética.

\section{A) A Idade da Razãa}

O primeiro livro da trilogia foi publicado em 1945, juntamente com o segundo livro, após o fim da segunda guerra mundial. Boa parte do livro foi escrita durante a guerra, embora muitas idéias já constassem de antes da guerra: Sartre começou a escrever desde 38 e continou a escrever o livro mesmo quando estava mobilizado e preso. Já autor de A Náusea e $O$ Muro e de alguns ensaios filosóficos, Sartre tinha agora um grande projeto: escrever um longo romance que tratasse exatamente de sua época, dos acontecimentos que ele presenciava.

Como o próprio título mostra, A Idade da Razão, o livro diz respeito a algo que é colocado em xeque, que se modifica. Estamos "na idade da razão" e se inicialmente podemos não saber o que é isso, se essa expressão só aparece na boca de Jacques, irmão de Mathieu, no capítulo VIII, já nas primeiras páginas o próprio Mathieu começa a nos indicar o que significaria esse título: caminhando após falar com um bêbado, ele pensa estar velho, o que logo depois é confirmado por Marcelle.

Trata-se, portanto, de uma certa razão que aparece ou deveria aparecer em determinada idade; mas o significado que muitos personagens dão a essa expressão só será conhecido aos poucos, ao longo dos capítulos, e talvez a questão mesma do livro seja a do confronto de significados, dos pontos de vistas, a maneira como Mathieu vê sua idade e seus problemas e como os outros o vêem - e não é à toa que a visão seja tão essencial nesse livro (Ivich e sua dor nos olhos, Daniel bêbado não conseguindo ver por causa do sol, odiando e ao mesmo tempo desejando ser visto e fixado no olhar de outros, Mathieu tentando se ver por meio desses olhares, quase todos os personagens "vendo" e julgando Mathieu).

E embora Mathieu não apareça em alguns capítulos, sem nomes e intitulados apenas por números, é sempre ele que é visado durante o livro todo. Mesmo que os outros personagens sejam mostrados em suas vidas independentes de Mathieu, é este o personagem principal, que olha e interessa ser olhado pelos outros personagens.

E assim como o personagem principal de Os Conquistadores de Malraux vai aos poucos sendo descrito e apresentado pelos personagens com quem o narrador se 
encontra; Mathieu também é "construído" aos poucos, de acordo com o que os outros personagens falam sobre e para ele. E não poderia ser de outro modo, já que tanto Malraux quanto Sartre fazem parte de uma literatura que abandonou o narrador onisciente e onipresente - e sem esse narrador, as características dos personagens não têm como ser colocadas desde o início de modo absoluto, já formado.

Mas diferente do personagem de Malraux, que só surge depois de uma longa série de descrições, aparecendo, portanto, com uma imagem já determinada (mesmo que não seja dada de forma definitiva, que seja formada por inúmeras descrições e comentários, ele só surge em cena depois desse quebra-cabeça montado), Mathieu aparece no primeiro capítulo de $A$ Idade da Razão, sem que nada saibamos sobre ele e no início continuamos a quase nada saber, já que ele não é mostrado em sua casa ou profissão, mas sim em um lugar freqüentado por qualquer pessoa: uma rua. Os romances de Sartre penetram imediatamente na vida dos personagens, em seus cotidianos.

Mathieu surge, na rua, sendo segurado por um homem que lhe pede dinheiro para comer e o primeiro comentário que aquele faz pode nos passar uma idéia de um homem moralista, julgando os outros: o que Mathieu pergunta é se o dinheiro não seria para a bebida e não para a comida. Mas logo em seguida essa impressão é desfeita, já que Mathieu diz que na verdade pouco se importa se é para comer ou para beber.

No entanto, se essa impressão inicial é logo desfeita, ainda persiste a de que ele é um homem preocupado com o que os outros pensam: ao ver um guarda ali perto, tenta se despedir apressadamente do homem para que o policial não o visse. Nessa cena, na qual o guarda é que iria repreender e o homem seria repreendido, o único preocupado é aquele que não tem relação alguma com a história. Mathieu fica inquieto e preocupado, enquanto o homem nem percebe o guarda e este recrimina o outro sem qualquer seriedade.

Mathieu dá uma desculpa ao guarda e o homem continua a falar, desejando retribuir a moeda que o outro lhe dera - e após decidir que desejar felicidade era muito pouco, decide dar-lhe um cartão-postal com um selo de Madri. Mathieu agradece quase que indiferentemente, mas não deixa de perceber que essa cidade tinha um significado especial para o bêbado, que dizia querer ir para lá e toca com sentimentalismo o cartão. 
Nessas primeiras páginas de um romance que será sempre centrado em um só personagem e em suas preocupações pessoais, a guerra não deixa de aparecer. Mesmo que não apareça de forma presente e importante, ela não está ausente: a guerra da Espanha surge logo no início e para o bêbado ela é importante. Mas se é certo que a guerra aparece logo, é certo também que ela não aparece do mesmo modo como nos romances de Malraux: nesses, a guerra é sempre desejada - os personagens participam dela, e não porque estão infelizmente no lugar em que ela ocorre, mas porque vão ao encontro dela. Em A Idade da Razão não vemos isso: a guerra é citada, aparece por meio de um selo mas é um homem bêbado que fala de sua tristeza por não estar na Espanha. Não temos aqui personagens em busca de aventuras e glórias. Pelo contrário: temos homens que parecem ser comuns em uma rua. É com um bêbado e um homem de quem nada sabemos que o livro se inicia - do modo mais cotidiano e comum possível, em uma rua - e não a caminho de guerras. Como diz Albérès, "son oeuvre est la continuation de celle d'un Malraux. Un Malraux qui n'utilise ni l'exotisme ni la révolution, qui n'a pas été en contact avec la mort, le courage, l'humiliation et le combat, mais qui a plutôt connu la laideur de la vie quotidienne et banale"269.

$\mathrm{O}$ bêbado fala e Mathieu recusa o convite para beber em um bar. $\mathrm{O}$ homem preocupado com o olhar e a reação do guarda parece ser também um homem apressado, cheio de compromissos. E logo descobrimos o motivo de sua pressa: ao deixar o bêbado, Mathieu continua a caminhar na rua e pensa no que acontecera, na recusa em beber com o desconhecido e vê que sua vida muito mudara: se antes aceitava esses descaminhos, se conversava com todos e ia aos bares, agora não fazia mais isso, achava mesmo que não valia a pena conversar e beber com o desconhecido, mesmo porque não teriam nada a dizer um para outro. Mas isso é mais tentativa de convencimento do que real convicção: é por remorso e por sentir-se velho que Mathieu pensa nada ter a dizer para o desconhecido.

Esses pensamentos são, no entanto, logo interrompidos pela chegada adiantada de Mathieu ao lugar em que ia. Às $22 \mathrm{~h} 25$ passa na frente de uma casa e vê que Marcelle ainda devia cuidar de sua mãe e que era preciso esperar a luz de seu quarto acender para ele entrar. Ele caminha mais um pouco, pensa no pouco dinheiro que tinha para passar até o final do mês - e volta a casa de Marcelle.

${ }^{269}$ ALBÉRÈS. La révolte des écrivains d'aujourd'hui - p. 204. 
O relacionamento que Mathieu mantém com Marcelle parece ser um relacionamento escondido, não permitido... afinal, se fosse permitido, o que impediria Mathieu de bater na casa de Marcelle enquanto a mãe dela estivesse acordada? E qual seria o motivo dessa visita escondida?

Aparentemente não há nenhum motivo, e é o próprio Mathieu quem pensa isso. Sem fazer barulho, entra na casa de Marcelle e maldiz o som que a porta faz. Se por um lado há toda essa preocupação por fazer tudo escondido de Mme. Duffet (entrar depois que ela dorme, tomar cuidado com o barulho da porta, tirar os sapatos para não fazer o degrau ranger), percebemos que não há nada de aventura nessa história e nem motivo para se esconder. Mathieu, ao pensar que na próxima vez traria óleo para colocar na porta, nos faz ver que ele já tem bastante intimidade com Marcelle e essas visitas às escuras e escondidas.

E quando Mathieu chega ao quarto de Marcelle, qualquer impressão que ainda persistisse de suspense e aventura desaparece: o que vemos são apenas fórmulas repetidas de velhos amantes - rituais, sapatos colocados no armário, diálogos que se mostram mais monólogos constrangidos (sem que nenhum tenha vontade de falar) que conversa entre duas pessoas, e um sexo que seria totalmente corriqueiro e mecânico caso algo não fosse revelado antes.

Assim que finaliza o ritual de deixar os sapatos no armário, Mathieu olha para Marcelle, a cumprimenta e percebe que algo não ia bem, mas nada fala além do "como vai" tão sem sentido e mecânico. Ele reclama da falta de dinheiro, e continua seu ritual. Tirando a roupa, percebe outro indício de que algo estava diferente (Marcelle colocara uma foto sua de 10 anos atrás em cima de uma cômoda)... e quando ela descreve o dia da foto, dia em que era magra e se sentia bem, vemos o contraste com as observações de Mathieu: enquanto ela relembra esse dia, ele observa sua voz tão masculina, seus gestos tão bruscos e seu corpo tão cheio de carne, de gordura; enquanto ela diz que não sente falta daquele tempo mas sim da vida que poderia ter tido, Mathieu pensa que a doença a impedira de continuar os estudos e que a vida não tinha sido fácil para ela, que mesmo ele dava muito pouco a ela: 4 noites por semana, contando o que fizera durante o dia e ouvindo os conselhos dela (como se fosse ela quem vivesse no lugar dele, por procuração, como ela dizia).

Enquanto Marcelle tenta se mostrar alguém interessante, que fora jovem, que já quis algo de sua vida, Mathieu só consegue ver a Marcelle atual, gorda, doente, vivendo por procuração, só ouvindo o que ele vive. E à medida em que conversam 
(com o narrador deixando claro que nem Mathieu nem Marcelle gostam de se falarem - se ele fala com um gesto cansado, ela o faz sem nenhuma vontade), outros personagens aparecem (tal como Ivich, que Mathieu tinha visto naquele dia) e informações são dadas (como o fato de Mathieu ser professor e ter iniciado o período de férias); e a desconfiança inicial de Mathieu de que algo não ia bem aumenta cada vez mais, ainda mais quando ela comenta que tinha saído pela manhã, ela que quase nunca saía de seu quarto por causa da doença.

Mas se percebe isso desde o início, se vê que ela estava nervosa, ele nada comenta; sabe que o melhor é esperar que ela "naturalmente" fale. A comunicação parece se dar mais no silêncio e na espera do que na própria fala ${ }^{270}$. Enquanto ela não se decide a falar, Mathieu comenta do desconhecido bêbado que encontrara na rua e com quem não fora beber. Diante desse comentário, Marcelle começa a falar com mais energia, criticando Mathieu. Ela diz que a vida dele era cheia de oportunidades perdidas, que agora ele tinha medo do patético, coisa que não tinha antes. E enquanto ele tenta em vão se defender (o narrador nos diz que Mathieu sabia que ela estava certa), Marcelle continua o ataque: "seulement, sais-tu ce que je crois? Que tu es en train de te stériliser un peu. J'ai pensé ça aujourd'hui. Oh! tout est net et propre, chez toi; ça sent le blanchissage; c'est comme si tu t'étais passé à l'étuve. Seulement, ça manque d'ombre. Il 'y a plus rien d'inutile, plus rien d'hésitant ni de louche. C'est torride"271..."au fond, c'est ça ton idéal: n'être rien"272.

Marcelle ataca Mathieu de forma dura, criticando as principais convicções de seu amante, até mesmo sua grande lucidez - que não permitia qualquer espécie de sombra, de inútil, de patético (enfim, de humano) - e seu vício e obsessão: o gosto pela liberdade. Para Marcelle, Mathieu nada mais fazia porque queria preservar sua liberdade, mas essa liberdade se mostrava justamente para isso: para nada. Ele continua a se defender, diz que isso não é um vício, mas Marcelle mal ouve, ri nervosamente, e confessa não desejar para si essa liberdade que Mathieu tanto preza. E se ele ainda tenta completar o ritual, dar início ao sexo, sentindo o prazer aumentar, não consegue: pára diante dos olhos abertos e fixos de Marcelle - e enfim ela responde o que lhe acontecia; e o que acontecia com ela era exatamente que "acontecera", ela estava grávida de dois meses.

\footnotetext{
${ }^{270}$ Cf. SAWADA. Ecriture et morale - question éthique chez Sartre.

${ }^{271}$ SARTRE. "L'âge de raison" In Oeuvres Romanesques - p. 402.

${ }^{272}$ IBIDEM - p. 403.
} 
Se inicialmente ele não acredita, logo pergunta (mais afirmando que perguntando) se o tirariam. Marcelle diz que conhece o nome de uma mulher que fazia abortos e cobrava pouco, mas Mathieu diz que não a deixaria ir em um lugar ruim. Ele se compromete a visitar a mulher para ver as condições nas quais ela opera, e caso ela não fosse confiável, falaria com uma amiga. Estamos, portanto, diante da grande questão: abortar ou não? Ainda não se coloca nem se pensa na possibilidade de não ter o aborto, mas agora a pacata vida de Mathieu terá que ser transformada em uma corrida por dinheiro e por um aborto que seja sem riscos para a saúde já precária de Marcelle. O professor de filosofia se despede e diz que em dois dias tudo estaria resolvido.

Já nesse primeiro capítulo, o personagem principal é colocado diante de uma questão fundamental, que é o aborto. Embora pouco saibamos ainda de Mathieu e de sua relação com Marcelle, já sabemos que essa relação com um aspecto tão aventureiro e novo é já uma relação antiga e duradora, e que agora "dava fruto", um fruto aparentemente não desejado por nenhum dos dois.

Depois que ambos se despedem, é Mathieu quem voltamos a acompanhar. O capítulo se inicia com Mathieu caminhando na rua e termina do mesmo modo: com ele saindo da casa de Marcelle e caminhando, tentando esquecer que ela carregava um filho e sabendo que ela não tinha como esquecer isso - e se sente alívio no início por estar "fora", por não estar mais naquele quarto sufocante e diante do olhar de Marcelle, logo percebe que esse olhar não o abandonara. Mesmo na rua, a consciência de Marcelle (essa consciência pesada que o chamara de velho, de perder todas as oportunidades e de ser livre para nada) o persegue e o julga. Para fugir da força dessa consciência, Mathieu entra em um bar, faz-se visto por outros e diante dessa presença de vários olhos, acalma-se e faz Marcelle menos presente ${ }^{273}$.

Nesse primeiro capítulo, portanto, Sartre já nos coloca em presença do personagem principal, Mathieu, e de algumas questões que ele e Marcelle se colocam: o que é envelhecer? como lidar com o aborto a ser feito? Mas ao invés de continuar com Mathieu e seu problema, no capítulo seguinte somos apresentados a outros personagens: Boris e Lola.

\footnotetext{
${ }^{273}$ Para terminar seu périplo pelas ruas, Mathieu vai até a casa da mulher que faz aborto e vê que as condições ali são deploráveis. Pensa que é necessário encontrar, no dia seguinte, uma outra pessoa para isso.
} 
Deixamos Marcelle em seu quarto e Mathieu na rua, após a visita à mulher que fazia aborto, e continuamos a noite com Boris e Lola, em provavelmente alguma boate - e nos mesmos esquemas do primeiro capítulo, estamos diante de um casal e o personagem que narra os acontecimentos é Boris, o homem, e não Lola, a mulher. Mesmo que ela julgue, critique, olhe, é sempre a impressão de Boris sobre o olhar dela que vemos (assim como acontecia com Mathieu e Marcelle).

Mas se os personagens mudam, não resta dúvida que Mathieu continua presente. É nele que Boris pensa, em seu professor de filosofia chamado Mathieu Delarue (só agora descobrimos que ele é professor de filosofia, e com o sobrenome Delarue - de la rue, da rua, como muito já se comentou: o homem que é "da rua", igual a todos, homem cotidiano, bem diferente dos heróis solitários e superiores de Malraux), e também em Lola, que certamente o olhava com um olhar apaixonado, mas com quem não desejava falar.

O diálogo aparece aqui também de modo forçado, assim como entre Mathieu e Marcelle: Boris deixa Lola olhá-lo, mostra seu perfil a ela e em troca deseja o silêncio, mesmo sabendo que inevitavelmente ela logo perguntaria no que ele estava pensando.

Parece haver um inevitável nos diálogos, ao menos no modo como eles são pensados por Mathieu e Boris: este sabe que Lola logo o questionaria sobre seu silêncio, e aquele também sabia que Marcelle não ia bem e que seria necessário esperar até que ela decidisse falar o que era. Os diálogos são cheios de não-ditos e de rituais - talvez porque seja o silêncio que melhor diz a impossibilidade de se dizer o indizível da existência ${ }^{274}$.

Nesses diálogos supérfluos ou fracassados, vemos bem como a existência é justamente o incomunicável, como a solidão e a incomunicabilidade imperam na realidade humana e como o Outro é, mais que uma companhia, um problema: "un dialogue qui, loin de simplifier les rapports entre deux sujets, redouble leur complexité, renforcera cette impression d'isolement et fera ressortir les problèmes crées par la présence d'autrui dans le monde" ${ }^{275}$.

Em um diálogo tão comum e cheio de dúvidas (e não de modo grandiloqüente, como no teatro, ou lúcido como em Malraux), há lugar também para a previsibilidade: Lola logo pergunta em que Boris pensa e esse se recusa a dizer, diz que não pensa em nada. Mas Lola diz que não pensar em nada é impossível e que gostaria de saber tudo

${ }^{274}$ Cf. LOUETTE. Sartre: la littérature, herméneutique du silence.

${ }^{275}$ LOUETTE. Sartre: la littérature,- herméneutique du silence - p. 23. 
que se passa pela cabeça dele, mostrando o quão apaixonada e controladora é - Boris, no entanto, recusa o controle e diz pensar em coisas tolas que não mereciam ser ditas; e mostra saber que na verdade ela tem medo de perdê-lo, de deixá-lo entediado por ser mais velha que ele.

E se Boris pensa que o que acontece é o contrário, gostar de Lola justamente por ela ser mais velha, ele nada diz. Pensa de novo em Mathieu, também mais velho, e de quem gosta tanto. Mas novamente seus pensamentos são interrompidos pela possessiva Lola. Então Boris resolve revelar em quem pensava, já sabendo que isso iria provocar brigas (assim como Mathieu falou com reservas sobre Ivich, irmã de Boris, para Marcelle, por ela não gostar da outra mulher; Boris não gosta de falar de Mathieu para Lola, que nunca o compreende). Boris diz, a contragosto, que pensava em Mathieu e Lola fica magoada por ele sempre pensar em outra pessoa e nunca nela.

Enquanto Boris elogia a seriedade e o desprendimento de Mathieu ( o fato dele não se prender a nada, ser livre), Lola desconsidera a importância disso e chega mesmo a debochar dele: para um funcionário público, professor de liceu, amante que não sai do quarto, com um apartamento só para si e com uma aposentadoria garantida era muito fácil não se prender a nada. Lola se diz mais livre que Mathieu, já que não tinha vínculo concreto com nada: seu trabalho era incerto, vivia em hotéis e só se prendia a Boris porque o amava.

Se as mulheres criticam Mathieu, Boris, seu aluno, o defende: diz que embora Mathieu tenha todas essas garantias, ele não liga para elas - e que se a liberdade de Lola é dada sem ela querer, a de Mathieu é desejada: mesmo que ele use suas garantias, ele o faz de modo indiferente - ao que Lola retruca dizendo que Mathieu não era de modo algum indiferente em relação à irmã de Boris, Ivich; magoando-o e encerrando assim a discussão.

Esse capítulo, além de mostrar outros dois personagens, mostra-os em relação a Mathieu. Não temos como pensar que poderia se tratar de vários personagens principais, relacionados ou não, mas que têm importância semelhante. Desde o início desse segundo capítulo, é em Mathieu que Boris pensa e a discussão com Lola gira em torno dos princípios daquele professor, assim como já acontecera no primeiro capítulo.

O que começamos a ter são vários olhares, pontos de vistas sobre Mathieu: ele mesmo se olhando e se achando velho; Marcelle confirmando a velhice e criticando o vício da liberdade que para nada serve; Boris defendendo essa liberdade tão querida e 
Lola criticando esse desejo fácil e abstrato demais. Aos poucos, começamos a conhecer Mathieu: um homem de uma certa idade, professor de filosofia em um liceu, que se encontra diante de um momento crítico de sua vida: além de se mostrar melancólico pelo homem que já fora e no que se transformou, achando-se velho; descobre que sua amante estava grávida. E essas questões, para um homem que, apesar de todas as seguranças que tem (o emprego, o apartamento, a amante de tantos anos), deseja ser livre, são cruciais.

Mathieu é um homem que deseja não se prender a nada e ao mesmo tempo encontra-se preso a tudo (nem mesmo para conversar com um bêbado acha-se mais disposto). $\mathrm{O}$ homem que preza sua liberdade acima de tudo encontra-se, já no primeiro capítulo, diante de dois acontecimentos que poderiam ameaçar completamente sua liberdade: a idade e um filho. E mesmo reconhecendo, para si (ao discutir com Marcelle), que sua liberdade pode não ser tão livre como pensava, o que Mathieu tentará fazer é justamente se livrar desses "obstáculos", tentando efetuar o aborto e flertando com a tão jovem Ivich.

No próximo capítulo vemos novamente Mathieu, após a noite em que descobre a gravidez de Marcelle, de novo na rua e na caminhada em busca de um aborto que preservasse a saúde de sua amante. Vai à casa de Sarah (mulher de Gomez, extremamente bondosa e que já fizera um aborto há muito tempo atrás) para obter o endereço da pessoa que fizera o aborto nela - e pensa em ir depois à casa de Daniel ou na de seu irmão Jacques, advogado, para arrumar o dinheiro.

Chega na casa de Sarah e a encontra conversando com Brunet, velho amigo de Mathieu; e embora se mostre contente em rever o velho amigo, sente-se desconfortável em falar sobre o aborto na frente dele. Mas não é sobre esse assunto que falam: quando Mathieu chega, Sarah e Brunet discutem sobre um homem que ela admitira na casa dela, um alemão - e nessa discussão ficamos conhecendo um pouco mais da vida deles. Brunet é um homem do Partido Comunista que usava a casa de Sarah para alguns encontros e informações, inclusive sobre Gomez, o marido de Sarah, que a abandonara com filho pequeno para lutar na Guerra da Espanha.

E embora Sarah fosse uma mulher bondosa e continuasse a amar Gomez, não perdoava essa procura pela guerra, pela defesa do PC... para ela, a vida do alemão era muito mais importante e concreta que a sobrevivência de um partido, algo extremamente abstrato; e por isso defendia o homem enquanto Brunet o acusava de ser espião. E se Sarah tentava trazer Mathieu para a discussão, ele se recusava a 
participar e só observava o quanto Brunet nunca parecia estar sozinho (o PC lhe dava multidões e consistência). Esse homem tão "forte" diz admirar Mathieu como professor de filosofia, mas que não era disso que se tratava ali - eram questões práticas e a opinião de Mathieu não valia nada sobre esse assunto. Brunet se despede, não sem antes notar que seu antigo amigo não tinha uma cara boa e que por isso passaria na casa dele às 14 horas para conversarem um pouco.

Sarah volta, depois de fechar a porta, e Mathieu é então direto: Marcelle estava grávida, nenhum dos dois queria o filho e ele desejava saber o nome da pessoa que já tinha feito aborto nela. E embora Sarah diga que se arrependera de ter feito (fizera apenas porque Gomez pedira), ela não julga Mathieu e se compromete a falar com um médico judeu que estava refugiado em Paris e era muito confiável (mais que o que fizera aborto nela).

Mais uma vez a guerra da Espanha e problemas sociais aparecem nesse romance. Mesmo que de forma apenas alusiva e sem importância para Mathieu, já nos confrontamos com o bêbado que queria ir à Espanha, com Gomez que fora à guerra, com Brunet e os problemas do PC, com um possível espião alemão e agora com um médico judeu que estava refugiado. Mas todos esses problemas ainda não são suficientes para fazer Mathieu pensar em outra coisa além dele mesmo. Se os acontecimentos já se mostram graves o suficiente para Gomez, Brunet e o médico austríaco refugiado, para Mathieu eles ainda estão distantes demais para prejudicar sua rotina e esquecer seus problemas pessoais.

E é sua rotina que continuamos a seguir: ele agradece Sarah, pede para ela ligar para ele em um bar e caminha até o Jardim de Luxemburgo, onde pensa em sua vida e em Marcelle grávida, no modo como seus amigos e próximos o viam. E junto com a melancolia da constatação da idade ("trente-quatre ans que je me déguste et je suis vieux. J'ai travaillé, j'ai attendu, j'ai eu ce que je louvais: Marcelle, Paris, l'indépendance; c'est fini. Je n'attends plus rien") ${ }^{276}$, vem a descrição de como os outros o vêem, qual o julgamento que eles fazem de Mathieu - e essa descrição é exatamente o que Marcelle lhe tinha dito na noite anterior: "C'est comme ça qu'ils me voient, eux, Daniel, Marcelle, Brunet, Jacques: l'homme qui veut être libre. Il mange, il boit, comme tout le monde, il est fonctionnaire du gouvernement, il ne fait pas de

${ }^{276}$ SARTRE. "L'âge de raison" In Oeuvres Romanesques - p. 443 
politique, il lit L'oeuvre et Le populaire, il a des ennuis d'argent. Seulement il veut être libre, comme d'autres veulent une collection de timbres" 277.

E ao lembrar de algumas cenas de sua infância e adolescência, vê que sempre quis ser livre, ser causa de si - e que tudo isso eram palavras vazias e pomposas: o ato livre e refletido pelo qual sempre esperou não existia, ele não se engajou quando era necessário, como Brunet fizera, e agora nada mais havia a esperar. Mesmo com essa constatação, Mathieu continua seu ritual de não se engajar, de tentar eliminar qualquer obstáculo a essa liberdade que ele já começa a ver que de nada serve - e assim como o aborto não é posto em questão, agora é a tentativa de negar sua "velhice" que veremos.

Mathieu vai a um bar e espera por Ivich, irmã de Boris. Pouco à vontade, ele conversa com ela e lhe pede um drinque, do qual ela diz não gostar mas gostar de beber o que não gosta. Ele a vê como uma jovem cheia de caprichos, e parecer ser o contrário de Marcelle: enquanto esta é totalmente previsível, Ivich sempre surpreende. No entanto, mesmo assim, Mathieu sabe como é preciso falar com ela (com um tom de bronca carinhosa).

Apavorada com seus olhos, que doíam nesse sol de verão forte em Paris, Ivich se mostra totalmente trágica, dizendo que com certeza algo lhe aconteceria, que ela não tinha futuro algum - e Mathieu, mesmo que concorde (que só consiga enxergá-la do modo como é agora, sem passado nem futuro), não fala.

E logo que uma mulher passa na rua, atraindo o olhar de Ivich, avisam Mathieu que Sarah estava no telefone. Ela diz que o judeu concordara em fazer o aborto mas precisava ser em no máximo dois dias, já que depois ele fugiria para os EUA, e cobraria 4000 francos, o que é um valor muito alto para o pouquíssimo dinheiro de Mathieu. Preocupado, ele volta à mesa e Ivich o avisa, mudando totalmente de idéia, que gostaria de ver a exposição de Gauguin. Sem ficar surpreso com a mudança, Mathieu chama um táxi, e os dois ficam incomodados: eram um homem e uma mulher dentro de um táxi, e é desse modo que Mathieu resolve agir. Enquanto Ivich fala mal de Lola, Mathieu se livra ao menos momentaneamente do peso das questões que o atormentavam desde a noite anterior e puxa Ivich para perto de si, abraçando-a e beijando-a. Ela se deixa ir mas não corresponde.

Em silêncio, chegam ao museu e o autor decide abandoná-los e passar a Marcelle. Depois de Mathieu ter tentado resolver o problema do filho procurando um

${ }^{277}$ IBIDEM - p. 443. 
médico para realizar o aborto (no terceiro capítulo) e o problema da idade ao flertar com uma jovem (nesse quarto capítulo), ele é abandonado junto a Ivich e é Marcelle que surge. Após a traição, que ajudara Mathieu a não pensar em seus problemas, é a traída que aparece, em seu quarto, acordando e sentindo náusea por causa da gravidez, que para ela era impossível esquecer.

Marcelle aparece pensando em Daniel, um amigo de Mathieu, com quem se encontrava em segredo. Não eram amantes, mas mantinham os encontros em segredo, coisa que agradava a ambos: essa amizade inofensiva, essa visita de que Mathieu nem desconfiava, dava a ela a sensação de que tinha uma vida que o amante não conhecia. E Daniel, a quem ela chamava de Arcanjo, ao contrário de Mathieu, mostrava-se bastante interessado nela. Ela relembra como Daniel lhe fazia perguntas e desejava saber como ela estava, enquanto Mathieu, por conta de algo que combinaram há muito tempo (cada um diria tudo ao outro), calava comodamente: se Marcelle quisesse dizer algo, ela o diria, não era necessário nada perguntar. Já que eles tinham combinado tudo se dizerem, era óbvio que ela lhe diria tudo... mas como já pudemos perceber no primeiro capítulo, o diálogo de ambos mostrou o tempo todo que nenhum dos dois dizia tudo que queria ou precisava dizer.

No banheiro, sentindo todo o peso de sua gravidez, o vômito que vinha e que felizmente era pouco perto do que muitas mulheres sentiam, Marcelle relembra a conversa que tivera com Mathieu na noite anterior e como ele conservara sua consciência tranqüila, sem nenhuma dúvida, sem nenhum instante de paralisação: logo ao saber que ela estava grávida, Mathieu não hesitara em falar do aborto, só porque isso já fora comentado por ambos há dois anos. E Marcelle, ali, esperando por um segundo de hesitação para poder manifestar sua dúvida, seu desejo de ter o filho e não abortá-lo, para poder dizer que agora que sentia a vida nascendo nela, não sabia mais se queria abortar... mas ele não teve esse segundo de hesitação; e ela se calou.

Para não odiá-lo, para não detestá-lo diante de tanta falta de consideração, Marcelle tenta pensar que o melhor mesmo é o aborto, que isso nem devia ser tão ruim assim, mas não conseguia se impedir de passar docemente a mão em seu ventre ${ }^{278}$.

Mas é para Mathieu e Ivich no museu que logo voltamos. Ao entrar ali, Mathieu pensa nas formalidades que é necessáio seguir (falar baixo mas firme), nas regras da "República Francesa" e respeitando-as, apresenta Gauguin a Ivich, que nada

\footnotetext{
${ }^{278}$ É uma Marcelle bem mais feminina que vemos nesse capítulo, bastante diferente de como Mathieu a via.
} 
fala. E se era a primeira vez que Ivich via os quadros, Mathieu já estivera nessa exposição, mas o que sentia agora era totalmente distinto do que sentira: se antes ele via os quadros, se antes esses tinham algum sentido, agora, na presença de Ivich e de seu ato, ele percebia que o quadro depende da pessoa para existir ou não: "il se sentait sec. D'ailleurs, il ne voyait pas le tableau: Mathieu était sursaturé de réalité, de vérité, transi par l'esprit de la Troisième République; tout ce qui était réel, il le voyait (...) Mais pas les tableaux; les tableaux s'étaient éteints" 279.

E se Ivich permanecia calada, tudo muda quando um casal entra na sala em que estavam e, sentindo-se naturais naquele lugar, sem o desconforto que nosso personagem revelava sentir, comenta em voz alta sobre os quadros. Ivich começa a rir do casal e Mathieu a leva para sentar, temendo uma crise de riso... mas ela, desanimada por ter mais gente ali, e cansada, pede para ir embora, sem ver toda a exposição.

Já na rua, sob o sol que fere os olhos de Ivich, ambos conversam sobre Gauguin, de sua loucura e beleza, de já jovem se mostrar capaz de tudo. Mathieu, sentindo ciúme da beleza de Gauguin, diz que antes de fugir para o Taiti ele era um "pintor de domingo", tentando assim se comparar ao pintor, já que ele era um escritor de domingo. Mas Ivich não o poupa: de modo cruel, critica Mathieu, diz que ele nunca será capaz de mudar seu modo, que até estende as mãos para alcançar o que está próximo, mas que nunca iria atrás do que está longe, e o culpa por ser extremamente metódico com seus jornais e programas culturais semanais que preparava para ela, dos quais, embora gostasse, detestava ser obrigada a ir.

Ele começa a se desculpar por tudo que fazia e diz que tentaria mudar (é a primeira vez que Mathieu se descontrola, nem mesmo diante de Marcelle grávida o vemos desse modo, tentando agradar outra pessoa, prometendo mudar). Mas ela mal ouve. Mathieu chama então um táxi para Ivich e assim que fecha a porta do carro, é Marcelle quem reaparece. Ele se encaminha então para a casa de Daniel, um velho amigo, para quem pediria dinheiro emprestado para o aborto.

É justamente Daniel quem aparece no sétimo capítulo, não no mesmo horário em que deixamos Mathieu (mais ou menos ao meio-dia). Voltamos à manhã, horário em que Daniel acorda e se prepara para sair. E se já sabemos um pouco sobre ele, se tanto Mathieu quanto Marcelle já pensaram nele, é só agora que ele se apresenta.

\footnotetext{
${ }^{279}$ IBIDEM - p. 468. Essa idéia está de acordo com o que Sartre escreve em $O$ imaginário, de que a arte não é o real, e exige um olhar imaginário para ser apreendida e compreendida.
} 
Daniel aparece em seu apartamento, que é descrito como sendo impessoal, quase vazio, e pensa no projeto para o dia, em algo que sabe que fará até o meio-dia mas que os leitores ainda não sabem o que é. O que acompanhamos são seus cuidados consigo próprio, e de modo detalhado. Nós o vemos fazendo a barba, todo preocupado em não se cortar, para não estragar seu rosto bonito, que tanto atrai as mulheres (a filha da zeladora, Marcelle). Já pronto, sai às $10 \mathrm{~h} 25$ com seus 3 gatos em uma cesta coberta (e o gato que mais ama é justamente o mais arisco, e o que menos ama é o mais dócil e passivo, a quem ele comparará mais tarde com Marcelle) e sente-se mal ao sair na rua, por causa do sol e da bebedeira da noite anterior ${ }^{280}$.

E se Daniel diz à zeladora que levará os gatos, doentes, até a casa de sua irmã, logo vemos que isso não é verdade: mesmo que ainda não saibamos o que exatamente fará, o vemos pensar no rio Sena. Mas antes de cumprir seu compromisso, para em um bar para beber e se irrita quando o garçom decide o que lhe trará ("o de sempre", um uísque). Ele é o primeiro personagem que se mostra irritado com o olhar definidor dos outros. Enquanto Mathieu reflete sobre o modo como os outros o vêem e se pergunta se realmente seria assim, Daniel se mostra indignado com essa mania que os outros têm de catalogar as pessoas, de defini-las como a um coisa, e ao garçom que o cataloga, ele se desmente, pede outra bebida que não uísque.

Volta à rua e novamente fica cego diante da absurda claridade. E quando começa a ver claro de novo, pensa no que seria o inferno: uma visão que tudo percebe; definição não por acaso relacionada ao olhar do garçom e tentativa de definir Daniel. O inferno, para este, é justamente o olhar que tudo vê (e embora essa questão só seja colocada em Sursis, já podemos deduzir aqui que aquele que tudo vê, que é onisciente, é justamente Deus). E ao pensar no ato que fará, tenta se convencer de que é um ato gratuito, que só através do mal que se faz a outro é que é possível tornar-se merda, que só é possível atingir-se indiretamente. Se por um lado Daniel detesta ser olhado e fixado, po outro ele deseja participar desse inferno, fazer-se mal.

Quando desce do ônibus começamos a conhecer os projetos de Daniel: sem pensar nos gatos que já tinham machucado um ao outro na cesta, tentando não pensar no que fará com eles, lembra-se da quantidade de dinheiro que ganhara esses dias na Bolsa e se lembra de Marcelle, no desprezo que tem por ela. Enquanto Marcelle pensa

\footnotetext{
${ }^{280}$ Só para Mathieu esse sol parece não incomodar.
} 
nele com carinho, com a certeza de que ele se importa com ela, vemos agora que Daniel despreza a amante de Mathieu, em quem pensa logo a seguir.

Durante os preparativos de seu ato (e agora já sabemos o que é: ao lado do rio, pega uma pedra, começa a embrulhá-la em um pano e pensa na melhor maneira de jogá-la com o cesto na água), pensa em Mathieu e no quanto sua tão querida liberdade era uma farsa, que ele próprio era muito mais livre que Mathieu, e que isso ele mostraria agora, ao matar seus amados gatos.

No entanto, se Daniel deseja se fazer mal, conseguir por meio de si próprio alcançar o inferno (que, se é execrável quando levado pelos outros, é desejável quando ele mesmo consegue isso), não é agora, com a morte dos gatos, que realizará esse desejo. Com tudo já pronto, Daniel desiste: vê-se como um homem que ama seus gatos e que não quer matá-los. Ele procura o desprezo, o fazer-se mal, mas sabe que infelizmente isso só é possível pelo Outro, pelo olhar do garçom, pela morte dos gatos, pelo que detesta. É por meio do que tem horror que Daniel alcançará o que deseja (seu mal), mas não é agora que conseguirá isso. Será preciso esperar pelo final do romance para que ele realize seu desejo de se colocar no inferno que não suporta.

Daniel desiste de matar seus gatos e volta para sua casa, onde encontra Mathieu (que como já vimos no capítulo anterior, saira do museu e ia à casa de Daniel para pedir dinheiro emprestado), que lhe deixava um bilhete. Ambos entram na casa e Mathieu comenta algo que a zeladora dissera (que Daniel tinha ido à casa da irmã, mas este diz que era apenas uma inocente mentira - e sente prazer em dizer isso, em confirmar a imagem negativa que Mathieu, sempre parecendo tão seguro e superior, tinha dele). Quando Daniel termina de cuidar dos gatos que tinham se machucado, Mathieu logo diz que Marcelle estava grávida e que ele estava em uma situação ruim, precisando de dinheiro para abortar a criança. Daniel segura o riso, sente-se contente ao ver seu amigo nessa situação complicada.

Mas nem mesmo nessa circunstância Mathieu parece se alterar: ele continua a dizer que não ama Marcelle, que não quer o filho, mas que continuará a vê-la, a cuidar dela. Parece que a gravidez e o aborto em nada transformariam a vida dele nem seu relacionamento já morto com Marcelle. E crente que sua vida continuaria a mesma, pede dinheiro para Daniel, que surpreendentemente nega, dizendo que perdera na Bolsa, o que o leitor sabe ser mentira. E essa mentira não é dita para convencer nem mesmo Mathieu. Daniel tenta colocar uma entonação que revelasse a mentira, que revelasse que na verdade ele não queria dar o dinheiro (para que, se uma imagem é 
sempre formada pelos outros, ao menos é uma imagem que ele deseja que tenham dele). E mesmo assim, Mathieu não insiste e pensa em sua outra opção de empréstimo: o irmão advogado e moralista.

Quando saía da casa de Daniel, este diz que no fundo está feliz por não ter dinheiro, pois essa era uma ótima oportunidade para Mathieu mostrar que era livre, casando-se com Marcelle. Para Daniel, esse ato mudaria toda a vida de Mathieu, e estar diante de um ato tão radical era muito raro - e o que seria a liberdade senão estar apto para transformar-se totalmente? Mas Mathieu diz que o casamento não o tenta de maneira alguma, e que ele não seria igual aos milhares de pais que vê todo dia no liceu.

Mathieu, assim como os personagens de Malraux, parece não se prender a nada. E se não mostra nenhum desejo por guerras, aventuras em países distantes nem mesmo por ser chefe de nada, é certo que também espera por algo maior e mais importante, por algo que o faça superior. Mesmo que os temas sejam mais cotidianos, que Sartre fale do dia-a-dia de um professor em Paris, seu personagem principal revela os mesmos gestos de superioridade, solidão e arrogância que os personagens de Malraux: a diferença mais marcante talvez seja que, se os personagens deste escritor vão ao encontro do ato que os fariam heróis, Mathieu apenas espera por esse ato que ele nem mesmo sabe qual é.

E talvez seja justamente esse desejo de grandeza e superioridade aliado à passividade que torne Mathieu tão criticado pelos próprios amigos e amante. Enquanto ao redor dos personagens principais de Malraux sempre havia respeito e uma amizade forte, nem a amante e os velhos amigos de Mathieu o respeitam totalmente: Marcelle tenta não se sentir decepcionada, mas vê que Mathieu não se interessa por ela e em nenhum momento se abalou com sua gravidez; e Daniel se irrita com esse homem tão vazio e ao mesmo tempo tão cheio de si.

Depois de Daniel ter-lhe negado dinheiro, Mathieu volta à rua e caminha em direção a casa de seu irmão Jacques, que também se recusará a dar o dinheiro. Ele chega na casa e escritório de Jacques e antes de falar com ele conversa um pouco com a esposa Odette, com uma beleza e inteligência sutis, tão diferente das mulheres com quem convivia. E quando sobe para falar com seu irmão, logo se arrepende, sabendo de antemão (novamente o diálogo já dito, já determinado) que não receberia o dinheiro e sim um sermão. Jacques o recebe bem, e logo Mathieu diz precisar de 4 mil 
francos para o dia seguinte, o que faz seu irmão ficar espantado (se era normal o irmão pedir dinheiro emprestado, o valor e a urgência eram maiores que o normal).

E ao invés de dizer que não emprestaria, o advogado Jacques começa a fazer considerações e julgamentos sobre o pedido. Se tudo que Mathieu desejava era ouvir logo um não e ir embora, ele terá que antes ouvir as críticas que seu irmão faz - e essas críticas são, assim como as de Marcelle, bastante duras.

Primeiramente Jacques diz que, no lugar de Mathieu, não teria coragem de pedir dinheiro para um burguês e de usar os laços familiares que tanto despreza para convencer o outro a lhe dar dinheiro. Assim como Lola, que já dissera a Boris que era muito fácil ser livre quando se tinha todas as garantias, Jacques também critica a abstração dos princípios de seu irmão: para ele, era fácil demais (e incoerente) dizer-se contrário aos valores e moral da burguesia sabendo que tem um irmão rico e burguês para quem pode, sempre que quiser, pedir dinheiro. Para Jacques, Mathieu quer romper os laços, mostrar-se contrário à moral burguesa, mas nunca corta realmente suas relações burguesas, não se sente mal em recorrer a elas diante de uma necessidade também estritamente burguesa - o dinheiro.

Mas Mathieu, já cansado de tanto ouvir críticas seguidas uma a outra (Marcelle na noite anterior, Ivich e Daniel naquele dia), diz que não pretende discutir e revela que quer o dinheiro porque Marcelle está grávida e iria abortar, o que na época ainda não era permitido na França. É então que Jacques endurece ainda mais em suas críticas e diz que não ajudará Mathieu a mentir para si mesmo, que ele não só era um burguês com vergonha como também um homem casado, que seu relacionamento com Marcelle, embora não fosse oficializado, era em tudo semelhante a um casamento normal, já que eles se viam regularmente e muitas vezes nem mesmo desejo ainda deviam sentir um pelo outro.

Para Jacques, o que Mathieu deseja é muito cômodo: ser contra a burguesia mas pedir dinheiro a um burguês sempre que quiser; ser contra o casamento mas manter uma relação em tudo semelhante a um casamento; é enfim conservar todas as aparências de liberdade e se livrar de todas as dificuldades e inconvenientes do casamento e outros compromissos. E com essa situação totalmente cômoda, Mathieu acaba por humilhar quem está à sua volta, Marcelle principalmente, que nunca ousaria dizer que não concorda com o que o amado pensa.

Mathieu aparece mais uma vez como um homem extremamente acomodado e ambicioso: ao mesmo tempo que deseja uma vida superior e diferente, aproveita tudo 
que a burguesia pode lhe trazer de vantajoso. Ele deseja todos os privilégios dos valores burgueses sem os compromissos e inconvenientes que eles trazem consigo. É por isso que mantém uma relação marital e conserva seu modo solteiro de ser; é por isso que não se importa em gastar mais dinheiro do que tem e pedir dinheiro para seu irmão: o que Mathieu deseja é o conforto do casamento e do dinheiro sem as preocupações e compromissos; é, em uma palavra já muito gasta por ele: ser livre. E quando novamente Mathieu fala que quer manter sua liberdade, Jacques retruca desse modo: "J'aurais cru, moi, dit Jacques, que la liberté consistait à regarder en face les situations où l'on s'est mis de son plein gré et à accepter toutes ses responsabilités" ${ }^{281}$.

A cada personagem para quem Mathieu defende sua liberdade, ele ouve críticas. Marcelle diz que a liberdade dele é para nada, Daniel diz que sua liberdade deveria servir para transformar-se radicalmente, e agora Jacques diz que ser livre era aceitar as responsabilidades das situações nas quais nos colocamos. O tempo todo Mathieu se confronta com outras concepções de liberdade, mas ainda defende a sua, uma liberdade que não exija nenhum engajamento, nenhuma responsabilidade - o que é duramente criticado por Jacques. Para este, Mathieu deveria se conscientizar que estava "na idade da razão", o que é interpretado pelo personagem como sendo "idade da resignação" 282 .

Após o irmão oferecer dez mil francos para ele se casar com Marcelle, o que ele recusa, Mathieu liga para Marcelle para avisá-la que seria impossível ir àquela mulher que ela conhecia e que ainda não tinha conseguido dinheiro nem com Daniel nem com Jacques, mas que continuaria a procurar. Ela então, de modo bastante irônico, diz para ele encontrar logo o dinheiro e desliga sem responder quando percebe o esforço de Mathieu ao dizer que a ama. É só depois de dizer que a ama, mesmo sendo dito apenas por causa das circunstâncias (ele já disse a Daniel que não sente mais nada por Marcelle) e dela ter desligado o telefone em sua cara, que Mathieu pensa na possibilidade dela querer o filho - mas essa hipótese é rapidamente descartada, já que ela várias vezes zombara das amigas que tinham tido filhos.

Antes de chegar em sua casa, Mathieu "de la rue" compra um jornal e novamente a guerra da Espanha retorna ao livro. Um bombardeio em Valência era o tema do jornal que lia, e embora tentasse sentir raiva de todos esses acontecimentos,

\footnotetext{
${ }^{281}$ IBIDEM - p. 508.

${ }^{282}$ É apenas nesse oitavo capítulo que o título do livro é dito. E se para Jacques a idade da razão é a idade na qual os compomissos deveriam ser seriamente assumidos, para Mathieu ela significa a idade da resignação, da perda da liberdade; e por isso ele a nega tanto.
} 
dessa guerra, não conseguia - a raiva que conseguia ter era uma raiva forçada, fingida. A guerra ainda não era capaz de fazer Mathieu se interessar por outros problemas que não os dele mesmo.

Mathieu parece não se envolver verdadeiramente com nada, nem com a gravidez de Marcelle, nem com a guerra da Espanha. Todos os acontecimentos parecem ser indiferentes, alheios. Mathieu não os vive, quer apenas se olhar vivendo. Ele finge sentir raiva do bombardeio em Valência assim como finge se importar com Marcelle, assim como finge viver. E sem se envolver com as notícias do jornal, volta para casa e lá encontra Boris, que tanto o admira. Mathieu confirma que à noite iria à boate Sumatra para ver Lola e Boris e Ivich, mas a conversa entre os dois não prossegue porque a campainha toca e Brunet entra (o amigo que encontrara cedo na casa de Sarah e que tinha dito que passaria no apartamento de Mathieu), pedindo para falar a sós com Mathieu, que fica contente em ver o amigo. Mas embora a amizade ainda existisse, embora Brunet tenha ido lá apenas por ter visto que de manhã Mathieu parecia mal, este logo percebe que quem está ali, à sua frente, não era o velho amigo mas um militante do Partido Comunista.

E é justamente uma proposta que Brunet vem fazer a Mathieu: que este entre no Partido Comunista, não para ajudar o partido (que já tem intelectuais demais, até mesmo para vender), mas para ajudar Mathieu, para dar um sentido à vida deste. É nestes termos que Brunet faz a proposta: "Tu es fils de bourgeois, tu ne pouvais pas venir à nous comme ça, il a fallu que tu te libères. À présent, c'est fait, tu es libre. Mais à quoi ça sert-il, la liberté, si ce n'est pas pour s'engager? Tu as mis trente-cinq ans à te nettoyer et le résultat c'est du vide (...) Tu as renoncé à tout pour être libre. Fais un pas de plus, renonce à ta liberté elle-même: et tout te sera rendu"283.

E se Mathieu tentava convencer os outros e a si mesmo de que sua liberdade ainda fazia sentido, agora ele age de modo diferente: diante de Brunet e de sua proposta, Mathieu confessa que realmente se sentia como se vivesse com idéias com as quais não se podia viver. Enquanto Brunet fala, Mathieu concorda com tudo, admira seu amigo que soube, na hora certa, engajar-se, filiar-se ao PC, encontrar algo em que acreditasse e pudesse justificar sua vida.

Mesmo assim, diz a Brunet que precisa pensar, que precisa de razões para entrar no PC e que ainda não as tinha. Embora admire seu amigo que soube escolher,

${ }^{283}$ IBIDEM - p. 521. 
ser livre de verdade, Mathieu não aceita a proposta. Nem a gravidez nem a guerra nem o partido são suficientes para fazer Mathieu sair de sua abstração e se engajar.

E se chegamos a um ponto que poderia ser essencial para o destino de Mathieu, não é com ele que continuamos. Deixamo-nos em sua casa e voltamos a Daniel, agora na rua indo a casa de Marcelle. Passa antes na quermesse do boulevard Sébastopol, conhecida pela prostituição, principalmente a homossexual, e observa os homens perdidos diante das máquinas de jogos, sexo e dos jogos sexuais. Observa com raiva todo o jogo de dissimulação de um homem que chega, todo cheio de si, e procura por um jovem com quem combina se encontrar depois - e se pensa em assustar esse homem, em ridicularizá-lo fingindo ser policial, seu plano fracassa diante de uma voz que surge e o chama com outro nome, Mr. Lalique (nome que às vezes adotava na quermesse).

Quem o chamava era Bobby, antigo conhecido que sabia de coisas que Mathieu nem mesmo duvidava. Daniel ouve Bobby falar e se incomoda ao ver que o homem que pretendia humilhar agora o tomava como cúmplice. Tenta se livrar logo de Bobby, dando-lhe dinheiro e mandando-o embora - mas seu corpo não mais o obedecia. Bobby vai embora, mas antes diz onde ele e Ralph moravam, e Daniel guarda o endereço, sem conseguir não decorá-lo.

Daniel volta então a caminhar pela rua pensando no por que a boa vontade dos outros era mais boa vontade que a boa vontade dele, no por que eles eram o Bem e ele o Mal... e embora não achasse razão para dizer por que os outros eram o Bem e suas vontades eram boas, pensa que algo fazia ser sempre assim. Esse personagem aparentemente secundário coloca questões que são essenciais para se pensar o romance e Mathieu. A problemática do Olhar, do Outro e agora da Moral permeiam todo o livro (a dor nos olhos, a dificuldade para ver, a cegueira, o julgamento dos outros) e são sempre nomeadas por Daniel.

Mas esses pensamentos são interrompidos por um espaço no texto que nos mostra uma separação, e o que se pensa depois do espaço é sobre o olhar desconfiado que as pessoas poderiam ter sobre a mala que ele carregava, que parecia com a mala de um advogado. Em um primeiro momento poderíamos associar esse pensamento à questão do Bem e do Mal e do olhar do outro, questões que tanto atormentam Daniel. No entanto, logo descobrimos que não se trata mais de Daniel mas sim de Boris, caminhando na rua e pensando em como os outros o olhariam e o que pensariam dele. Mas se pensa nesse olhar, é com orgulho que deseja ser reconhecido como 
ladrão...imagina-se dando palestras em associação de ladrões, explicando sobre a psicologia do roubo e as técnicas que tinha aperfeiçoado. E se o roubo era motivado mais pela dificuldade que pela utilidade do objeto roubado, dessa vez ele roubaria algo útil: um livro imenso, bonito, que ficava sobre uma banca na rua.

Chega na livraria, encontra o livro e começa a folheá-lo... e quando resolve contar até 5, momento no qual sairia andando com o livro, sente uma mão sobre seu ombro - do mesmo modo que Daniel fora surpreendido na quermesse, agora é ele quem surpreende. Boris se vira e vê Daniel Sereno, e este, totalmente amável, começa a conversar com Boris sobre Mathieu e filosofia, mas o que ele deseja é que Daniel vá embora logo para conseguir roubar antes que a livraria fechasse. Quando isso acontece, Boris conta até cinco e rouba o livro com sucesso.

Após Boris roubar o livro, é com Daniel que vamos embora, é seus pensamentos que acompanhamos, e pensamentos sobre o quanto Boris era idiota, o quanto Mathieu pensava tudo saber sobre ele e dizia a todos seus conhecidos (incluindo Marcelle e Boris) quem era Daniel - e que este desejava desconstruir essa visão (agora, por exemplo, Marcelle o conhecia e sabia que Mathieu não conhecia quase nada sobre Daniel).

Daniel, que detesta o olhar fixador do Outro, quer determinar a visão que Mathieu tem dele, quer se fazer de mentiroso e arrogante para seu amigo só para desfazer essa mesma imagem para Marcelle. Ele gosta de brincar com essas visões, de jogar com esses olhares e se jogar no inferno, não por vontade dos outros mas por vontade própria. Mas ele desejava mais que simplesmente desconstruir essa imagem que o superior Mathieu fazia dele: ele o detestava, desprezava Marcelle e tudo faria para complicar ainda mais a situação já complicada: já negara dinheiro a Mathieu e agora visitaria Marcelle e a faria confessar caso quisesse ter o filho (o que era muito provável). Daniel queria obrigar Mathieu a se casar com Marcelle e com toda a atenção e carinho que dedicava à desprezível amante de Mathieu, conseguiria a confissão dela.

A trama estava armada: de um lado temos Mathieu querendo preservar sua falsa liberdade, e de outro temos Daniel fazendo tudo para Mathieu cair de seu pedestal de arrogância e superioridade - e Marcelle sendo o joguete de ambos para conseguirem o que querem. Grávida, ela aparece a Mathieu como mais uma oportunidade de reafirmar que ele era livre, que nada o prendia (nem a gravidez nem o aborto), e a Daniel como a oportunidade de constranger Mathieu a fazer o contrário do 
que desejava. E embora ela apareça em um curto capítulo pensando em si mesma, na gravidez e nos dois homens, Marcelle não tem força alguma, é um fantoche que adota o diálogo que o artista (Daniel ou Mathieu) deseja ${ }^{284}$.

E é isso que acompanhamos no capítulo seguinte: Marcelle sendo manobrada pelo "arcanjo" Daniel, que chega em sua casa e entrega bombons para sua mãe, que conta várias histórias repetidas antes de dormir e deixar os dois a sós ${ }^{285}$.

Estamos novamente no quarto de Marcelle, que ainda não sabe que Daniel sabia de sua gravidez. Mas diante da foto antiga dela, que ainda continuava exposta em seu quarto, e de sua cara cansada, Daniel resolve ser mais direto e diz saber que ela estava grávida. Se no início Marcelle se mostra irritada por perturbar o "arcanjo" dela com um assunto daqueles, logo conta que Mathieu lhe dissera que Daniel não tinha o dinheiro para emprestar para o aborto.

É então que Daniel confessa a Marcelle que tinha todo o dinheiro que eles precisassem, caso ela quisesse. $\mathrm{E}$ aos poucos ele a faz ver que Mathieu é quem decidia tudo, que ele já tinha tudo resolvido e era a ela que cabia discordar, o que talvez não tivesse coragem de o fazer e por isso aceitava as idéias de Mathieu... Daniel tenta mostrar o que realmente acontecia entre os dois e se mostra totalmente preocupado, interessado no que Marcelle pensava e sentia, sabendo que desse modo conquistaria facilmente a amante de Mathieu e a faria fazer o que ele quisesse.

Ele revela o tanto de hipocrisia que existe nesse acordo entre Mathieu e Marcelle, e consegue facilmente manobrar Marcelle: Daniel pergunta se ela realmente não quer ter o filho, e depois de algumas hesitações, culpas e questões práticas (como faria para criá-lo?), Marcelle confessa que quer ter o filho, que ele ao menos seria dela e sentiria sua falta. Diante da inabilidade de Marcelle de lidar com a situação, Daniel aproveita para traçar o plano como deseja: diz, já que Marcelle desejava ter o filho, que era necessário falar tudo isso para Mathieu, que ele com certeza entenderia as dúvidas dela e até mesmo o "segredo", que Daniel e Marcelle se viam freqüentemente e que tudo não passava de mais uma inocente mentira de ambos. E Marcelle, que sempre reluta no começo, acaba por concordar com todas as idéias de Daniel.

\footnotetext{
${ }^{284}$ Infelizmente, nas obras de Malraux e Sartre, a mulher quase nunca aparece como sujeito de pensamento e ação.

${ }^{285}$ É interessante notar que se Mathieu, mesmo sendo amante de Marcelle há sete anos, entra na casa desta apenas depois da mãe já ter dormido e faz tudo às escondidas, no escuro e sem barulho; Daniel não precisa desses jogos: ele não apenas visita Marcelle como convive e conversa com a mãe dela. Estamos diante de um lúcido Mathieu que prefere esconder seus compromissos e de um mentiroso e "mau" Daniel que ama tudo fazer às claras.
} 
Mas se ele faz tudo isso por ódio a Mathieu e desprezo a Marcelle, é justamente nesse ato de maldade e artimanha que descobre a bondade: ao desejar fazer mal, ao odiar Marcelle, percebe-se bom, humilha-a e ao mesmo tempo deseja violar sua consciência, ser um só com ela, na humilhação. "Elle le fascinait, ce tendre feu qui le dévorait, il ne savait plus si c'était le Mal ou la bonté. Bien et Mal, leur Bien et son Mal, c'était pareil. Il y avait cette femme, et cette communion repoussante et vertigineuse" 286 .

Daniel humilha Marcelle e assim faz o bem a ela - mas não se contenta com isso, quer ser a humilhação que Marcelle sente, quer ser ela nessa humilhação, fazer parte dessa comunhão vertiginosa, fundir-se ao que ele despreza, ser a Marcelle grávida, humilhada e desesperada. Que mal poderia ser mais bondoso? E se Daniel começa a concretizar seu plano de obrigar Mathieu a se casar com a desprezível Marcelle, este ainda nada sabe sobre isso. Enquanto os dois conversam em segredo no quarto dela, ele se encaminha para a boate Sumatra, onde veria Lola, Boris e Ivich.

Entra na boate e senta ao lado dos dois irmãos, tão jovens. Mathieu pensa que foi bom ter ido, pois no barulho era mais fácil se esquecer e esquecer os problemas. E para mostrar que esses problemas não o abalam, pede champagne e gasta todo o dinheiro que ainda tinha nessa compra e não se arrepende nem quando lembra que simplesmente não gostava de champagne (assim como Ivich e Boris costumam beber do que não gostam, Mathieu faz o mesmo aqui, talvez justamente para tentar se assemelhar aos dois irmãos, à juventude deles).

E enquanto uma mulher dança nua e depois Lola canta, os três ficam a conversar sobre o quanto Mathieu tem medo de perder o controle, mesmo quando muito bebe, e Ivich parece não se lembrar ou pelo menos não se importar com o que acontecera pela manhã no táxi - é em Lola cantando, com toda beleza e sofrimento, que todos agora prestam atenção. E se Ivich se encanta com sua beleza, Mathieu pensa no sofrimento: assim como não conseguira ter raiva ao ler a notícia de Valência sendo atacada, sabia que sofria pouco, e se exagerava no sofrimento era porque mentia. Ele ainda tinha o luxo de poder fingir que sofria, enquanto Marcelle já não podia ignorar o sofrimento real, físico. E já que não era um salafrário, ele a ajudaria a sair desse sofrimento: ou arrumaria logo o dinheiro ou se casaria com ela, não havia outro jeito. Mas naquele noite, naquele momento, não havia mais o que fazer e tudo que Mathieu

${ }^{286}$ IBIDEM - p. 571. 
queria era não pensar em nada, era esquecer, era negar todos os atos responsáveis (beber o que não gostava, gastar todo o dinheiro em champagne, ver Ivich).

Quando Lola para de cantar e se junta aos três na mesa, temos várias danças e conversas. Ivich tira Lola para dançar e Boris e Mathieu ficam à mesa conversando sobre o punhal que aquele comprara (como recompensa do roubo bem-sucedido) e sobre o dinheiro de que este precisava (Boris nota o ar preocupado de Mathieu e este confessa o motivo) e que não conseguira com o amigo nem com o irmão. $\mathrm{O}$ aluno sugere pedir para Lola, que tinha dinheiro guardado e não o usava, mas Mathieu sabe que ela não gosta dele e por isso não emprestaria o dinheiro. Pede, mas sem insistir o suficiente, para que Boris não fale com ela, o que obviamente ele não respeita: leva-a para dançar e pede o dinheiro, inventando uma desculpa qualquer, na qual Lola não acredita e se irrita, dizendo que não iria emprestar o dinheiro.

E enquanto novamente Lola dança com Ivich e Boris dança com outra mulher (para fazer ciúme e se vingar do não empréstimo de Lola), Mathieu fica sozinho na mesa e não consegue se esquecer de si mesmo: vê-se casado com Marcelle, morando com ela e se vê determinado para sempre: "Pour toujours l'ancien amant de Marcelle et, à présent, son mari le professeur, pour toujours celui qui n'ai pas appris l'anglais, qui n'a pas adhéré au Parti Communiste, celui qui n'a pas été en Espagne, pour toujours" $^{287}$.

Se até agora sua vida era voltada para o futuro, para o grandioso ato que ele tanto aguardava, agora, prestes a se casar com Marcelle (por não querer prejudicá-la e por não ter encontrado o dinheiro), vê sua vida já definida e em relação ao passado. Casado, ele deixaria de ser um homem livre aberto aos acontecimentos e ações... ele seria apenas o que não fizera de seu passado. O casamento aparece para Mathieu como o fim definitivo de qualquer liberdade, de qualquer possibilidade - e se agora pensa em se casar com Marcelle é apenas porque ele é um ser superior que não gostaria de ver a amante sofrer.

No momento em que Lola, já drogada, chama Boris para ir a seu camarim (para continuar a discutir sobre o dinheiro pedido por ele), Mathieu para de pensar em si. Ivich senta-se na mesa e ele esquece de Marcelle e de si para olhar Ivich, que se dizia bêbada e não se importar com os resultados das provas (que sairiam na tarde seguinte). Para provocar a vizinha, que a olhava com ar reprovador, corta-se com o

${ }^{287}$ IBIDEM - p. 600. 
punhal de Boris e sua mão sangra. Mathieu também reage e critica Ivich, mas ela o provoca, dizendo amar ver seu próprio sangue - e que isso com certeza escandaliza o "certinho" Mathieu.

Irritado, ele pega o punhal e o crava na mão. E faz isso não só para responder à provocação de Ivich, mas para desafiar todos que tinha visto naquele dia e o criticaram - Jacques, Brunet, Daniel; para mostrar que era capaz, como Gauguin, de atos radicais, de ação e sangue - mesmo que essa ação não passasse de um ato infantil e inútil de cortar a própria mão.

Essa é a ação que Mathieu realiza. Como resposta a todas as críticas que ouvia, como desafio a todos os que se achavam superior por agir, o filósofo também age, mas sua ação é só para vingar-se, para corta-se e não para se comprometer com algo. Parece que um corte na mão, ato tão individualista, é a única coisa que Mathieu consegue fazer; e nesse ato tão sem conseqüências, ele pensa desafiar a todos, se vingar.

A noite acaba com a voz de Lola cantando... e no dia seguinte acordamos com Mathieu saindo de sua casa e vendo um bilhete que Daniel deixara pedindo para ele procurá-lo ao meio-dia. Antes Mathieu vai ao encontro de Ivich em um bar, onde ela já o esperava, nervosa e sem ter conseguido dormir. Ela diz que não queria voltar para a casa dos pais, que eles não mais apostariam nela caso não passasse nas provas, o que com certeza aconteceria. E diante de tantos problemas concretos presentes na vida de Mathieu (como conseguir dinheiro, que atitude ter com Marcelle, como conseguir arrumar algo para Ivich continuar em Paris), ele não consegue mais pensar. É então que Boris, sem ser esperado, chega no bar desesperado, dizendo que Lola tinha morrido.

Enquanto bebe para se acalmar, conta que ela se drogara mais do que o normal na noite anterior e que agora de manhã ele a chamara e ela não acordara e ao olhá-la, a viu morta - e diante dessa imagem aterrorizante, saiu correndo do hotel, sem que ninguém o visse. Mas ao contar o que acontecera, lembra que havia várias cartas sua em que falava de fornecedores de drogas e que seria perigoso se a polícia as encontrasse. Apavorado, pede para Mathieu ir até o hotel pegar as cartas (sem esquecer de contar onde o dinheiro dela estava guardado), e este (sem sentir pena de Boris) faz o que ele pedira: pega um táxi e vai até o hotel em que Lola vivia.

No caminho, do mesmo modo que pensara que sua vida de casado o tornaria um passado (o homem que foi aquilo, que fez isso), fechado para novas oportunidades 
(para o futuro, enfim), pensa que a morte tem o mesmo efeito. Se até ontem Lola agia pensando no futuro, agora, morta, era o que tinha feito, sua ação parou no passado, não é mais vista como destinada a algo futuro. $\mathrm{O}$ casamento é a morte para Mathieu.

Ele sobe até o quarto de Lola e a chama, sem ouvir resposta. Encontra as cartas e o dinheiro mas sai do quarto sem levar o dinheiro consigo. Já no corredor, irrita-se com sua falta de coragem e seus valores burgueses: bastava um gesto fácil para livrar Marcelle de todo sofrimento, mas ele não o fizera, não fora capaz de roubar - e se obedecia tanto a moral burguesa assim, então por que não se casar com ela? Mas só de se imaginar casado, Mathieu desiste da idéia e volta ao quarto decidido a pegar o dinheiro, a romper definitivamente com a burguesia - iria roubar e mandar a amante fazer o aborto.

Entra novamente no quarto mas dessa vez ouve a voz de Lola... Mathieu conversa com ela, que explica ter se drogado demais e desmaiado, e ele diz que Boris tinha ficado com medo e pedira para Mathieu ir até lá saber como Lola estava. Ele então vai embora com as cartas e sem o dinheiro. Encontra-se com Boris e Ivich no bar, entrega as cartas e os avisa que Lola não morrera mas só desmaiara. Boris não se dá conta da situação, mas Mathieu os deixa ali no bar para falar no telefone com Sarah e lhe pedir mais um favor (que ela pedisse um desconto ao médico judeu).

Depois Mathieu se encontra com Daniel em outro bar. Ambos bebem e este diz que tem um pouco de dinheiro para emprestar a Mathieu, não o suficiente para o aborto, o que Mathieu recusa por achar que esse pouco dinheiro não faria diferença alguma. Mathieu sabe que Daniel prepara algo e assim como esperava Marcelle dizer o que se passava, também agora espera e não compreende muito bem quando Daniel logo conta que tinha visto Marcelle no dia anterior...aos poucos ele explica que tem o costume de visitar Marcelle de tempos em tempos, que ele a admirava e por isso a via às vezes. No entanto, Mathieu continua a não acreditar, já que ela dizia tudo para ele e agora descobrira que ela mentia.

Para provar que era verdade e já tendo tudo previsto, Daniel entrega uma carta de Marcelle a ele, na qual ela se dizia ansiosa por ver o "arcanjo" e que sua mãe também o esperava. Mathieu lê a carta e não a reconhece com todo aquele estilo e modo de escrever, chamando Daniel de arcanjo! E tudo que consegue continuar a dizer é que "Mas nós nos dizíamos tudo", ao que Daniel retruca com um "é possível dizer tudo?", já começando a articular com o que falaria a seguir - que Marcelle não 
parecia estar bem, que comentara com rancor da atitude de Mathieu, dizendo que era sempre ele quem decidia tudo e que ela nunca tinha tempo de formar a opinião dela.

Mathieu continua a retrucar, a não aceitar nada que Daniel lhe dizia... fala que há dois anos eles já tinham conversado sobre gravidez e aborto e que tudo estava decidido. E então Daniel lhe pergunta se dois anos não era tempo demais, se as idéias não poderiam mudar, se as pessoas não poderiam ter dúvidas...Mathieu se rende, pergunta a Daniel o que exatamente Marcelle queria e o que ele deveria fazer. E ao invés de simplesmente dizer que ele deveria se casar com ela e ter o filho (coisa aliás que ele já disse e que não surtiu efeito algum), seria mais divertido e eficaz plantar a discórdia, o desentendimento entre ambos - e tudo isso, junto com a impossibilidade de Mathieu conseguir o dinheiro para o aborto, o levaria com certeza ao casamento. É por isso que Daniel responde que Mathieu precisa conversar com Marcelle e ver o que ela quer.

Enquanto eles conversam, enquando Daniel continua a executar seu plano de arruinar a vida de Mathieu, Marcelle fica em seu quarto, arrependida por ter reclamado a Daniel de Mathieu. Ela, vista sempre de forma tão dura e masculina, vêse extremamente mulher, fraca, "água" - e se torna ainda mais "mulher" quando Daniel lhe telefona para avisar que tinha conversado com Mathieu e que tudo fora melhor do que o previsto, que não fora nem mesmo necessário explicar o que acontecia, pois ele logo se deu conta de que fora injusto e que iria consertar o erro. Diante desse falso relato de Daniel (Mathieu o tempo todo tentou refutar o que aquele lhe dizia) e da perspectiva de um final feliz (o filho nascendo), Marcelle se alegra e sorri, põe uma rosa em seus cabelos e se torna cada vez mais feminina.

E se ela se prepara para a felicidade e se sente cada vez mais mulher, Mathieu se torna cada vez mais obcecado pelo aborto. Mesmo depois da conversa com Daniel, o que deseja é conseguir o dinheiro para se livrar do casamento e do filho, para continuar livre. E a imagem tão bonita da dura Marcelle se tornando água, da masculina Marcelle se tornando mulher, desmorona quando vemos Mathieu em uma empresa que faz empréstimos a funcionários públicos, sem, no entanto, conseguir.

Mesmo confessando a Brunet que era livre para nada, que tudo que pensava era uma ilusão, Mathieu continua a agir como se todas essas dúvidas não o atingissem, como se as questões fossem colocadas apenas externamente. Assim como a guerra da Espanha não o atinge verdadeiramente, todas as críticas que todos os personagens fizeram à sua concepção de liberdade também não parecem ser suficientes para abalar 
o seguro Mathieu. Nenhuma questão que se pôs até agora é suficiente para fazê-lo mudar sua ação. Mesmo sabendo que sua liberadade era mito e que Marcelle tinha dúvidas, o que ele continua a fazer é procurar o dinheiro para o aborto e a conservação do mito de sua liberdade.

Sem dinheiro e sem esperança, volta para sua casa e vê recado de Ivich dizendo que tinha sido reprovada e que estava inconsciente. Pensando que ela estaria mal e bêbada, e como sempre, esquecendo-se de todos seus problemas, Mathieu pega um táxi e sai em uma busca desesperada por Ivich, até encontrá-la em um dancing, completamente bêbada e dançando com um jovem. Ao vê-la entregue aos braços de outro homem, Mathieu se dá conta de todo seu desejo e ciúme, e sente vergonha disso. Ele a chama e ela pede para ser levada embora. Mathieu a leva até seu apartamento, onde ela nunca tinha entrado antes - e enquanto dorme, ele prepara um chá e fica a olhá-la, pensando no quão jovem ela era, no amor que sentia, mas no casamento que teria com Marcelle.

Ela acorda e começa a falar da volta para a casa dos pais, em Laon, e Mathieu tenta convencê-la a voltar para Paris, que ele encontraria um modo de sustentá-la, lhe daria dinheiro. E por mais insuportável que a vida em Laon lhe pareça, Ivich se recusa a aceitar o dinheiro de Mathieu, e só o aceita (de modo totalmente indiferente) quando este confessa que não faz isso por piedade mas por puro egoísmo, por vontade de revê-la.

A campainha toca e Sarah entra, interrompendo a conversa entre Mathieu e Ivich, e na frente desta, avisa Mathieu que o médico não aceitava o dinheiro depois, que tudo teria que ser pago na hora. Após dar essa notícia que destrói todas as esperanças de Mathieu ainda conservar sua liberdade ou ao menos permitir um aborto decente para Marcelle, Sarah vai embora e ele decide contar tudo a Ivich. Diz que vai se casar com Marcelle e não porque assim deseja, mas porque não tinha encontrado dinheiro para o aborto. E se Ivich diz que nada tem a ver com essa história, não perde a oportunidade de ser cruel: responde que não voltará a Paris, que Mathieu não tinha dinheiro nem para si mesmo quanto mais para ela, e quando ele tenta tocá-la, ela diz que aquilo era maneira de homem casado - exatamente como ele agira no dia anterior no táxi.

Mathieu se irrita, sai de seu apartamento batendo a porta e vai até um bar e depois volta a caminhar na rua até cair no chão e começar a rir, a rir de si mesmo, de Marcelle, de Ivich, de toda sua vida (há sempre esse vontade de se vingar dos outros, 
de, em um ato infantil, como quando cortou a mão de propósito, desafiar os outros). Ao levantar-se, vazio, pensa que seu futuro já estava condenado, morto. Mas novamente Mathieu não consegue não sentir nojo dessa constatação e lembra de algo que ainda pode fazê-lo fugir do engajamento: o dinheiro de Lola. Sabendo que ela naquele momento estaria na boate cantando e tendo ainda uma hora para ir até a casa de Marcelle, Mathieu decide ir ao hotel de Lola e lá rouba o dinheiro que antes não fora capaz de roubar.

O rumo do livro começa a mudar... se já dávamos certo o casamento de Mathieu com Marcelle, se ele próprio estava se conformando com isso, agora tudo muda. Ele rouba o dinheiro e sai rindo do hotel, livre.

Mas não pensamos muito em Mathieu e Marcelle: é para Daniel que o romance se volta cada vez mais. Se ele demora para aparecer no livro, depois sua presença é cada vez mais constante, e nem poderia deixar de ser assim, já que toda a trama é traçada por ele: ele não só não empresta o dinheiro a Mathieu como conversa com Marcelle e a faz dizer que queria o filho.

E agora Daniel aparece em sua casa, olhando fixamente um barbeador que estava em cima da mesa. Imagina-se castrado, jogado pelo chão, antevendo o que faria com o instrumento. Mas antes, pega 5 mil francos, coloca-os em um envelope e escreve o nome de Mathieu, deixando o envelope em cima da mesa, em um lugar para que todos vissem depois que o encontrassem morto. Pega então o barbeador e percebe que nada o impediria de alcançar o que quisesse, de se matar, de se mutilar ao menos. Com medo, deixa o barbeador cair sobre a mesa e sai correndo até o bar, onde, bebendo, compreende que na verdade sabia que toda aquela história não passava de uma simulação, de uma piada na qual chegara a acreditar e por isso fugira.

Assim como no dia anterior pensara seriamente em matar seus gatos e desistira no último instante, agora era ele mesmo que tinha desejado matar ou ao menos mutilar - mas também dessa vez não conseguira o que desejava: destruir-se, matar-se... mas ao pensar em Mathieu e Marcelle, que deveriam agora estar conversando, vê que ainda é possível encontrar o juíz severo que tanto deseja.

E sem ter a menor idéia de como Daniel conseguiria isso, é com a cena decisiva de Mathieu e Marcelle que nos deparamos. Assim que Daniel pensa em Mathieu e Marcelle conversando, que nada seria como nenhum dos dois imaginava, que de qualquer modo a vida de Mathieu agora deveria estar arruinada, é justamente 
para a conversa entre ambos que somos dirigidos e o que vemos é exatamente o que Daniel previra.

Mathieu chega na casa de Marcelle e repete todo o ritual que vimos no primeiro capítulo. Ele entra no quarto e a encontra bem arrumada, bonita, com flor no cabelo (totalmente "feminina", contrapondo-se à imagem do primeiro capítulo) e tratando-o muito bem, com remorso de ter pensado mal dele e com esperança que ele falasse o que ela desejava ouvir e o que Daniel lhe tinha prometido que Mathieu diria.

Ambos pedem desculpas pela irritação de duas noites atrás, quando ela revelara estar grávida, e depois os dois se silenciam. Mathieu pensa que Marcelle espera que ele diga e faça algo carinhoso e resolve acabar de vez com aquela comédia, aquela farsa: pega sua carteira e lhe mostra os cinco mil francos. Marcelle nada entende, começa a dizer que acreditava mas logo fica muda, apenas olha, incrédula, Mathieu, que continua a falar de coisas práticas, que Sarah iria com Marcelle no dia seguinte ao médico confiável.

Marcelle deseja então saber qual era a origem do dinheiro e Mathieu faz suspense até dizer que tinha roubado de Lola, afirmação diante da qual ela tem um acesso de raiva e riso. Mathieu pergunta o que ela reprovava, se ela queria se casar com ele, que ainda havia tempo de contornar a situação, mas Marcelle, ainda rindo e com uma extrema lucidez, diz que não havia mais tempo para nada, pois ela não o estimava mais e sabia que ele não mais a amava, o que ele confessa depois de um tempo de silêncio. Mas nem mesmo assim Mathieu desiste da aparência e de se mostrar um homem que se preocupa com sua amante. Enquanto Daniel quer fazer o mal a todo custo e assim se interessa por Marcelle e a ajuda, Mathieu quer fazer o bem e despreza ainda mais Marcelle, dizendo que poderiam ficar juntos mesmo com ele não mais a amando. Ela continua a rir e o manda embora; ele vai mas deixa o dinheiro no quarto... e quando já está na porta, ainda ouve o riso desesperado de Marcelle, que tira a flor de seus cabelos.

Mathieu volta a seu apartamento e vê que Ivich continuava ali, e continuava para pedir desculpas por ter sido tão geniosa. Ele conta a ela tudo que acontecera, que abandonara Marcelle e que lhe deixara o dinheiro, dinheiro que roubara de Lola. E se Ivich mostra-se também surpreendida com esse ato de Mathieu, ela o acha belo com esse ar tão sozinho... eles se abraçam, ela ajeita os cabelos do modo como Mathieu dizia gostar e quando ela entreabe os lábios, ele desiste, vê que ela não passa de uma 
criança e que se abandonara Marcelle, com certeza não fora por causa de Ivich, mas sim para nada.

Ele se afasta e diz que não conseguiria beijá-la. Enquanto se despedem, enquanto Mathieu percebe seu triste desejo, a campainha começa a tocar com insistência: era Lola que aparecia acusando Boris de ter roubado cinco mil francos. Drogada, sem saber ao certo o que dizia, conta que dinheiro seu tinha sumido e que era exatamente a quantia que Boris tinha pedido emprestado. Mathieu confessa que fora ele quem roubara o dinheiro, mas ela não acredita, pensa que ele está protegendo Boris. Mesmo assim, pede o dinheiro de volta e ri ainda mais quando ele diz ter dado a outra pessoa. Quando decide ir embora com a certeza de que Boris a roubara, abre a porta e dá de cara com Daniel, que pede desculpas por estar ouvindo a conversa, mas diz ter a solução para o problema do dinheiro: o que ele foi fazer na casa de Mathieu era justamente devolver o dinheiro que ele tinha dado à amiga. Sem acreditar, Lola pega o dinheiro e vai embora, deixando Daniel e Mathieu sozinhos.

O livro termina com Daniel e Mathieu, frente a frente; e aquele começa dizendo que esperara Mathieu sair da casa de Marcelle para lá entrar e que tinha ido lá para avisar que tudo tinha sido resolvido, que Marcelle não iria abortar a criança e que ela ia se casar com Daniel. Mathieu pensa no mais óbvio: se Daniel ia se casar com Marcelle era porque a amava e era amante dela, mas este diz que não se trata disso e que tinha ido até lá também para confessar algo.

Ambos começam a beber e Daniel dá início a uma conversa cheia de ironias: Mathieu pergunta como Marcelle estava e ele responde que Mathieu não tinha o direito de saber... Daniel diz também que não fizera nada por filantropia e que enfim Mathieu agora era livre e podia fazer o que queria, mas este já sabe que essa sua tão desejada liberdade para nada serve. Daniel vai até a casa de Mathieu para humilhá-lo, para mostrar a ele que fez o gesto que o outro não fora capaz de fazer e que agora se encontrava ali, sozinho, livre e destruído. O que Daniel queria era ver com os próprios olhos a desolação de Mathieu, ainda mais quando confessa, já na porta, prestes a ir embora, que era pederasta.

Mathieu não se importa com o fato do outro ser pederasta, mas deseja saber por que ele confessara naquele momento, ao que Daniel responde que precisava que alguém soubesse para poder acreditar, para poder ver nos olhos de Mathieu que ele, Daniel, era pederasta. Não só Mathieu não fora capaz de realizar o gesto necessário, de se comprometer, de assumir um ato que fizera, como encontrava-se diante de um 
amigo pederasta, que sempre considerara fraco, inferior, mentiroso, que soube assumir o ato que não fizera, que soube se responsabilizar pelo ato que o covarde Mathieu realizara.

Mathieu diz a Daniel que se sentia ainda pior por saber que era com um pederasta que Marcelle se casaria e que ele, um hetero, amante dela, que fizera o filho, não fora capaz de se casar. E quando Mathieu percebe que Daniel estava se casando com Marcelle para se martirizar, para se fazer mal, sente ainda mais inveja dele. Como ele próprio dissera ao lhe negar dinheiro, aquela era uma ótima oportunidade para mostrar-se livre, para fazer exatamente o contrário do que se desejava; e foi o que Daniel conseguiu fazer, ir até o mais fundo, ser livre. Mathieu "était fasciné par Daniel. Il pensait: 'Est-ce que c'est ça la liberté? Il a agi; à présent, il ne peut plus revenir en arrière: ça doit lui sembler étrange de sentir derrière lui un acte inconnu, qu'il ne comprend déjà presque plus et qui va bouleverser sa vie. Moi, tout ce passe comme si je pouvais toujours reprendre mes coups. Je ne sais pas ce que je donnerais pour faire un acte irrémédiable" 288 .

Daniel, o pederasta, sacrificava-se, martirizava-se, ia até o fundo da liberdade essa liberdade que Mathieu tanto defendia e da qual sempre fugira. Agora, diante de Daniel e de seu gesto, Mathieu percebia que não era Marcelle que impedia sua liberdade, que na verdade nada a impedia e no entanto, ele não era livre. Mathieu constata não apenas que não era livre, que se iludia o tempo todo ao pensar que sua liberdade seria ameaçada pelo casamento e filho, mas também que Daniel fizera exatamente o contrário (assumindo mulher e filho que não eram dele), e com isso se mostrava inteiramente livre.

O livro termina, portanto, com Mathieu concluindo que estava na idade da razão, nessa idade em que não se era mais possível não se comprometer, ter as ações que ele teve durante o livro todo. E se desde o início ele constata que está envelhecendo, que está modificando sua maneira de ser, o livro todo é a luta contra essa constatação: é não querer o filho, é não se casar, é flertar com Ivich... e agora via que todos esses atos e fugas eram inúteis. Diante de Daniel agindo e mostrando sua liberdade, não há mais como ignorar a ilusão na qual vivera ao menos nesses três dias em que a história se passa.

${ }^{288}$ IBIDEM - pp. 727 - 728. 
Mas se agora nos parece nítida e real a desilusão de Mathieu, é estranho que ele pense isso tão confortavelmente, sentado em seu sofá, sem sapato nem gravata. Talvez essas constatações sejam iguais às várias dúvidas que tivera durante o livro e que não foram suficientes para fazê-lo mudar. A impressão é a de que tudo isso pode não passar de mais uma farsa, de mais um sentimento forjado, mentido, exagerado. Os pensamentos tão torturosos e amargos de Mathieu não combinam com aquele cenário tão sereno, com um homem que tira sapato e gravata, que olha a calma e bonita noite $\mathrm{e}$ senta confortavelmente em seu sofá.

Mathieu parece resignado com a idade da razão: ao tentar conservar a todo custo sua concepção de liberdade absoluta e abstrata, o professor de filosofia se vê sozinho, sem nenhum acontecimento que agora poderia impedi-lo de ser livre (sem amante nem filho); e paradoxalmente, ao ser livrar de tudo que comprometia sua liberdade, ele compreende que ela não se dá de modo abstrato, que ela exige um comprometimento, uma vivência concreta, da qual ele fugira.

Mas essa percepção ainda não parece suficiente para fazer Mathieu transformar-se. O livro termina com o personagem sentado confortavelmente, sem qualquer indício de conversão. E mesmo quando age, não há nenhuma conversão radical, nenhuma mudança significativa ${ }^{289}$. Todas as dúvidas que mostra ter durante o livro não fazem Mathieu tranformar-se, agir no sentido de desejar incluir-se concretamente na história, ou vivê-la de modo mais cotidiano, mais modesto (embora viva o cotidiano, espera pela Ocasião que exigirá sua liberdade, espera por Algo que o faça mudar, mas pensa que esses acontecimentos não podem ser os do dia-a-dia). Ao menos nesse primeiro tomo da trilogia Os Caminhos da Liberdade, Mathieu caminha pelos descaminhos. Ele não se engaja, não assume Marcelle nem o filho, não vai à guerra da Espanha nem se filia ao PC. Mas essa crítica que recebe de quase todos, de Marcelle, Ivich, Lola, Brunet, Jacques e Daniel, levaria a que espécie de liberdade?

O que eles pedem é para Mathieu assumir algo, ser marido, ser pai, ser camarada do PC... é ser como a mesa é mesa, é tornar-se "ser na forma de ser". Eles desejam a sinceridade total, que Mathieu assuma ser o que é, sem qualquer espaço para indefinições e aberturas. Enquanto o professor de filosofia defende uma liberdade totalmente absoluta, que seria uma abertura total porque abstrata, Brunet e Jacques

\footnotetext{
${ }^{289}$ Não há, por exemplo, o momento de conversão que Sartre diz ser muito explorado na literatura, como no caso de Crime e Castigo. Para isso, ver $O$ ser e o nada, p. 586.
} 
pedem que ele se torne como eles, "representantes" do PC e da burguesia, classificáveis de modo concreto mas também definitivo como camarada do partido e burguês.

Estamos diante de dois extremos em relação à liberdade, e podemos associálos à situação exposta em $O$ ser e o nada de dois homossexuais, com um criticando o outro pelo modo como lida com sua homossexualidade. Se o que recusa ser homossexual tem a compreensão de que um homossexual não é homossexual como esta mesa é uma mesa, ele diz não ser homossexual não nesse sentido: "teria razão realmente se entendesse a frase 'não sou pederasta' no sentido de que 'não sou o que sou', ou seja, se declarasse: 'Na medida em que uma série de condutas se define como condutas de pederasta e que assumi tais condutas, sou pederasta. Na medida em que a realidade humana escapa a toda definição por condutas, não sou'. Mas o homossexual se desvia dissimuladamente para outra acepção da palavra 'ser': entende 'não ser' no sentido de 'não ser em si'. Declara 'não sou pederasta' no sentido em que esta mesa não é um tinteiro. Está de má-fé" 290 . E assim é Mathieu: se ele não quer ser definido como uma mesa é uma mesa, ele pensa que o único modo de conseguir isso é negando qualquer compromisso, é não assumindo nenhuma conduta que tem, do mesmo modo que esse homossexual tem condutas homossexuais mas as recusa.

E se o outro homossexual exige que o companheiro assuma sua homossexualidade, assim como Jacques e Brunet querem que Mathieu se assuma homem casado com filho e que se filie ao PC, eles não estão a salvo da má-fé. Eles pedem que o outro homossexual se diga homossexual e que Mathieu diga ser um homem casado com filho do mesmo modo como se diz "a mesa é uma mesa", de modo a coisificá-los, a defini-los totalmente. O "campeão da sinceridade", como diz Sartre, exige que o outro se torne coisa, exige que o outro se desfaça do indefinido que toda liberdade é.

Não se trata, portanto, de dizer que o "correto" é fazer o que Brunet e Jacques tão bem fazem (pensam desfazer-se da individualidade para se tornarem classes, para se tornarem coisa) e não o que Mathieu faz. Ambos os modos expressam extremos da liberdade, os extremos de como se conceber a realidade humana; e nenhum deles abarca a ambigüidade que somos. Nenhum assume ser o que é à maneira de não ser e o que não é à maneira de ser; nenhum deles compreende que se encontram nos

${ }^{290}$ SARTRE. O ser e o nada - p. 111. 
extremos ("sou o que sou" da mesma maneira que a mesa é uma mesa, assumindo suas condutas mas se identificando a uma coisa; ou "não sou o que sou" da mesma maneira que a mesa não é uma cadeira, assumindo a não coincidência consigo mesmo mas negando suas condutas), e não no ambíguo, no indefinido, no "sou o que não sou e não sou o que sou" (reconhecendo, ao mesmo tempo, suas condutas e o fato de não ser uma coisa).

A autenticidade, que Sartre diz ser possível, estaria justamente nesse assumir as condutas de modo a compreender que elas não nos definem, é dizer "sou homossexual" sem que isso justifique seus atos, sem que isso se torne tão definido e definitivo que não permita transformação alguma. Em $A$ Idade da Razão não temos uma disputa entre duas autenticidades mas entre duas má-fés: enquanto Mathieu opta por assumir sua transcendência e negar suas condutas, Brunet e Jacques optam por assumir as condutas e negar a transcendência.

E para o personagem que pensa ser livre de modo abstrato, reconhecendo sua liberdade mas ignorando suas condutas, a história não poderia ter importância. Para um homem que pensa ser total transcendência, como a imanência importaria, como os acontecimentos históricos poderiam ter alguma importância? Se é certo que ele vive o dia-a-dia de um professor de filosofia em Paris na época de suas férias, é certo também que ele espera por algo maior, por algum acontecimento importante que o faça sair dessa mesmice da vida cotidiana.

Se a história faz parte do livro, para o personagem Mathieu a história é insignificante. Para ele, a guerra na Espanha encontra-se distante, o médico judeu refugiado é mero detalhe: nada disso é capaz de interferir em seus problemas, em suas questões. Uma liberdade abstratamente absoluta não se deixa abalar tão facilmente por questões tão terrenas como a história.

E talvez, para um personagem que se quer de modo tão abstrato, que nega todas as condutas que mantém, que espera por algum acontecimento assim como alguns esperam Godot e outros Deus, a arte seja um modo de acessar a abstração tão ausente do cotidiano das preocupações mundanas.

No entanto, não temos nenhuma presença significativa da arte nesse romance: ela aparece apenas em alguns momentos, na exposição de Gauguin à qual Mathieu leva Ivich, e em Lola cantando na boate. Na exposição, Mathieu pensa no quanto já gostou daqueles quadros, e no quanto agora, com todos aqueles problemas concretos, 
com Ivich a seu lado, aqueles quadros nada diziam a ele. O que se mostra nessa cena é que é preciso uma certa disposição para se compreender a arte, uma disposição que talvez exija o esquecimento dos problemas cotidianos, o esquecimento de uma jovem que acabara de beijar, o que ele não conseguia esquecer. A arte parece exigir uma abstração, um modo distinto de se ver o quadro, um modo que não seja o real.

E no momento em que Lola canta, o professor de filosofia percebe que é na música, na melodia, que se pode sofrer de modo belo, de modo a negar todo o real. Só por meio da arte o sofrimento é belo porque fingido. A arte é o instante de abstração do real, abstração que consegue tornar até mesmo o sofrimento em algo belo.

Diferente de Malraux, que parece retratar em seus personagens o que ele mesmo pensa (o papel da arte para os personagens é muito semelhante ao que seu autor diz em textos mais teóricos), Sartre faz em seus romances o oposto. O papel que seus personagens atribuem à arte não é o que o autor pensa - e essa estratégia ressalta o caráter crítico da obra, pois assim o leitor se verá no personagem para tentar fugir do real através do "mundo" imaginário e terá de tomar uma posição sobre sua ação, ou seja, terá de se engajar, de se comprometer ainda mais com esse mundo do qual queria fugir.

O espelho que podíamos ver nas obras de juventude e maturidade de Malraux (com os personagens vivendo conforme o autor pensa) ou mesmo nas obras de juventude de Sartre, com o narrador revelando ironia e crítica em relação ao modo dos personagens viverem, não existe mais nos romances de Sartre. Ele abandona esse narrador tão direto e crítico mas não deixa de continuar a criticar, só que agora é a própria obra que se revela como crítica. Ela se mostra como o espelho deformador e no lugar do narrador que denuncia esse papel, surge o leitor, que o substitui com olhar irônico e nunca ausente.

Assim, se Mathieu parece pensar pouco na arte, e quase sempre a vê como abstração, é preciso ter distanciamento e olhar crítico em relação a isso: o leitor, mesmo que se identifique ao ler, terá de fazer uma escolha consciente em relação ao engajamento ou abstração. E mesmo que sua escolha seja contrária ao que Sartre revela em seus textos mais teóricos (que a arte é negação do real que o mantém como pano de fundo e que se volta para ele, nunca sendo uma total fuga), o autor consegue mostrar, malgrado o próprio leitor, que a obra exige o comprometimento, mesmo que seja o comprometimento com a abstração. 
O narrador dos contos de juventude impunha muito claramente suas idéias, e isso tornava os contos não muito literários. Agora a obra conserva sua ambigüidade de obra imaginária - e é o leitor que deve fazer o papel crítico que a obra de arte exige. Para isso, nada melhor que colocar um personagem negativo, que muito provavelmente pense igual ao leitor (isso é importante para o que o leitor seja atraído pelo livro), para fazer com que este torne sua ação, antes irrefletida e agora revelada pelo romance, consciente e reflexiva.

Nos romances de Sartre não há a concordância entre o que os personagens parecem buscar na arte e na ação e o que seu autor explica nos textos teóricos. E ao retratar personagens tão negativos, sua obra de arte torna-se, assim, mais crítica: permite mais facilmente a identificação do leitor com o personagem mas o obriga a se distanciar e a tomar uma atitude reflexiva em relação à tentativa de fuga pela arte, tentativa essa que se revela sempre fracassada. Não temos em Mathieu, portanto, um exemplo positivo do modo como Sartre pensa a ação e a arte: ao personagem ainda importa a fuga, a alienação da história e a arte lhe aparece como possibilidade de abstrair-se das preocupações mundanas - trata-se de um personagen negativo, que mostra como ainda é possível pensar na arte como abstração mesmo às vésperas de uma guerra mundial.

Mas como a história e a arte apareceriam em um mundo que em tão pouco tempo tanto se modificou? De junho de 1938 a setembro do mesmo ano, tudo muda: se antes Mathieu podia ignorar a história, agora ela o assalta, o invade; outra guerra mundial ameaça surgir e parece dinamitar todos os antigos modos de comportamento. Será que agora ele conseguirá ignorar essa história da qual tanto foge? Será que agora sua liberdade abstrata ainda faria sentido?

Esse é o tema do segundo volume da trilogia, Sursis, que veremos agora.

\section{B) Sursis}

Esse segundo volume, publicado ao mesmo tempo que A Idade da Razão, mostra-se, no entanto, bem distinto daquele. Se no primeiro tínhamos a narração focada o tempo todo em Mathieu, se a guerra na Espanha e a fuga de judeus apareciam apenas como pano de fundo que em nada modificava a questão principal, agora, já pelas primeiras linhas de Sursis, podemos ver que não se trata mais da história de um personagem com seus problemas em Paris: as primeiras informações que temos são de horários distintos em várias cidades e um mesmo pensamento (o que 
ele faz? Por que não desce?) - já aqui podemos ver que há vários personagens em diferentes cidades (cita-se, entre outras, Berlim, Londres e Marseille) confrontados a um mesmo pensamento, diante de um mesmo acontecimento.

Mas quem seriam esses personagens e acontecimentos?

$\mathrm{O}$ primeiro que aparece não tem relação alguma com o livro anterior e os dramas de Mathieu: Horace Wilson, do governo inglês, em um hotel no qual jornalistas esperavam por ele.

É a espera que liga os personagens nesse começo de romance. Embora ainda não saibamos ao certo quem são esses personagens nas diferentes cidades, nem o que Wilson irá dizer para que todos o agüardem, sabemos que todos esperam por algo, talvez pela definição ou suspensão definitiva da pena (já que Sursis significa pena suspensa).

E mesmo que um personagem não mais espere (Milan) é sobre isso que ele pensa, é sobre o fato de há dois anos não esperar mais. Só na segunda página um personagem já tão conhecido aparece, e também esperando: Mathieu surge junto com outros tantos personagens e inicialmente só lhe é dado duas linhas. É Milan com sua esposa grávida, Anna, quem primeiro aparece com certa importância, e não poderia ser de outro modo, já que eles se encontram na Tchecoeslováquia, palco essencial de todo o desenrolar da segunda guerra mundial e do acordo de Munique, que será assinado alguns dias depois ${ }^{291}$.

O livro todo se passa entre os dias 23 e 30 de setembro de 1938: uma semana que leva os franceses à guerra e os faz, no fim, respirar ainda por um tempo. Em $A$ Idade da Razão o acontecimento de também alguns poucos dias só fora suficiente para conscientizar Mathieu de que sua tão prezada liberdade para nada servia, para mostrar que Mathieu, como diz Blanchot, "necessita estar disponível e o é para nada. É livre, só, nada o amarra, mas sua vida está morta, ele está fixado, tudo está vazio. É assim que chegamos à 'idade da razão', essa idade séria que se resigna ao fracasso e sabe sobre ele construir uma vida confortável"292. Mas agora os acontecimentos são de outra ordem: não se trata mais de uma mulher grávida e de um aborto, mas de uma guerra que está prestes a explodir, com Hitler e os alemães exigindo terreno da

\footnotetext{
${ }^{291}$ Esse tema não estava inicialmente previsto no momento em que Sartre começou a escrever a trilogia. Ele escolheu narrá-lo porque desejava escrever sobre o que vivia, e na medida em que o acordo de Munique aconteceu em 1938, não era possível ignorá-lo em seu romance. Inicialmente não havia, portanto, nada de "histórico" em seu livro, mas o próprio desenrolar da história impediu que o autor ignorasse esses acontecimentos.

${ }^{292}$ BLANCHOT. A parte do fogo - pp. 192-193.
} 
Tchecoeslováquia; e diante de um acontecimento assim, não é só a vida de um personagem que se modifica.

É a vida de Wilson na Inglaterra, de Mathieu na França, a de Milan na Tchecoeslováquia e de todos os outros personagens ainda não nomeados mas designados por "eles". Parece-nos, na verdade, que esse "eles" pode ser preenchido por qualquer pessoa e em quase qualquer lugar - perante a guerra mundial que se anuncia, qualquer pessoa se encontra mergulhada no mesmo drama. Se a vida de uma criança interessa e modifica apenas seus futuros pais, a guerra e a paz interessam a todos. É por isso que de um romance centrado em questões tão pessoais passamos para um outro romance que alarga todas as questões, as fronteiras, o espaço e o tempo.

Em alguns poucos meses (A Idade da Razão se passa em junho de 38 e Sursis em setembro do mesmo ano) já não é mais possível viver como antes: com as invasões e exigências de Hitler, tudo se torna mais urgente, mais angustiante.

E também não se pode mais narrar do mesmo modo: o que interessa a Sartre não é somente o destino de alguns indivíduos em meio a uma guerra que se aproxima, mas justamente como o destino e a vida de todos se encontram transformados. É essa multiplicidade de angústias e visões, de histórias tão diversas que se identificam e se transformam diante de um mesmo acontecimento que lhe interessa. Seja em qualquer lugar (da Europa ao menos), todas as histórias voltam o olhar para o mesmo homem: Hitler e os outros governantes da Tchecoeslováquia, Inglaterra, França e Itália - e diante deles, todos os dramas se igualam: Mathieu deixa de ser o personagem principal, em torno de quem todas as outras pessoas giram. Ele continua a ter uma importância grande, mas muitos outros personagens surgem e com tanta importância quanto o professor de filosofia.

E para melhor compreender essa guerra "mundial", nada melhor que tentar estar em todos os lugares ao mesmo tempo, que tentar ser o Deus que não existe - e para sê-lo, é necessário esse recurso da instantaneidade, da onipresença, de poder ao mesmo tempo ver Wilson, Mathieu e Milan ${ }^{293}$. Em Sursis, temos uma narrativa na qual o ponto de vista da subjetividade é assumido nas suas formas múltiplas, para que melhor se caracterize a singularidade das situações particulares. Não há respostas

\footnotetext{
${ }^{293}$ Não existe um narrador onisciente, mas a narração, do modo mais fragmentado possível, tenta justamente mostrar como vários personagens, no mesmo tempo e em espaços diferentes, pensam e sentem a guerra que se aproxima. Não há um narrador que ligue os personagens e fatos, mas há uma mão que dirige o movimento da câmera de um personagem a outro - e se esse narrador não existe, não dá para ignorarmos que a intenção do autor é de atingir uma certa "onisciência", mostrar como todos se transformam com a guerra que se inicia.
} 
objetivas: há diversidade de expectativas e de esperanças, em conformidade com a diversidade de projetos. "A multiplicação das subjetividades em Sursis significa: todos os homens são iguais perante a culpa e a liberdade. E a narração simultânea dessa pluralidade subjetiva indica que a cada um lhe é dada a sua liberdade; ninguém pode exercê-la por outro" ${ }^{294}$.

E devido a esses recursos, nos é impossível empregar o mesmo método da leitura que realizamos até agora. Durante todos os contos de juventude de ambos, os romances de Malraux e $A$ Idade da Razão de Sartre, tínhamos uma história de certo modo linear, possível de ser seguida. Mesmo que não se tratasse de uma linearidade clássica, mesmo que os personagens não fossem dados como fechados, tendo as sempres múltiplas visões sobre os personagens principais - o que ocorre tanto em Malraux quanto em Sartre, até agora não tínhamos ainda nos confrontado com tamanha desconstrução e descontinuidade.

É certo que não se pode mais falar de personagens totalmente constituídos nos romances contemporâneos - e é justamente a problemática desse sujeito tão desfragmentado que se coloca em primeiro plano - e tanto Malraux quanto Sartre mostram esse sujeito perdido e em busca de si; mas mesmo nesses romances podíamos identificar a trama principal. Já em Sursis estamos diante de uma fragmentação absurda, tão absurda quanto a guerra que estouraria. Não temos nem mesmo um personagem principal e todas as histórias se dissolvem e se confundem.

Se em A Idade da Razão os capítulos ainda seguiam um ou poucos personagens, e nas poucas vezes em que se mudava de ponto de vista isso era indicado claramente (com uma linha em branco a separar um personagem de outro), agora nos é difícil determinar até mesmo sobre qual personagem se fala: em um mesmo parágrafo temos vários personagens que pensam e muitas vezes passamos de um personagem a outro sem perceber (as situações, as questões frente à guerra são às vezes tão parecidas que personagens bastante distintos e em lugares distantes uns dos outros dialogam sobre exatamente a mesma coisa - e se iniciamos o diálogo com os personagens $\mathrm{A}$ e $\mathrm{B}$ no lugar $\mathrm{C}$, ao chegar ao final do diálogo percebemos que não se trata mais deles, mas sim de $\mathrm{M}$ e $\mathrm{N}$ em O). E em muitos momentos isso se radicaliza a tal ponto que nem é possível dizer com certeza se aquela frase diz respeito ao personagem A ou $\mathrm{M}$.

${ }^{294}$ SILVA, Franklin Leopoldo e. Ética e literatura em Sartre - p. 130. 
Como então seguir a história de um romance quando o intuito do autor é justamente desconstruir a noção de história linear e com um só personagem principal?

Continuaremos a seguir a estrutura do romance e as questões que pensamos ser essenciais, sem no entanto ter a pretensão de dar conta da complexidade dos acontecimentos e ligações. A cada capítulo falaremos de modo geral das questões apresentadas e o modo como Sartre decide narrá-las, sem a obrigação de seguir fielmente a ordem do texto, adiantando algumas falas, atrasando outras, mas procurando sempre uma linha que possamos seguir, procurando desenvolver as questões que nos parecem importantes.

Ao contrário de A Idade da Razão, cujos capítulos eram apenas enumerados, aqui em Sursis todos são intitulados por uma data que para o leitor da época era óbvia, e para a qual era fácil dar um significado claro. O livro se passa em alguns poucos dias de setembro de 1938, quando Hitler estava no poder e já tinha iniciado suas conquistas - por isso, embora se trate apenas de uma semana, é uma semana decisiva para o rumo dos acontecimentos na Europa - são sete dias em que se passa da certeza da guerra à certeza (falsa, como todos que lêem o livro sabem) da paz. Mas no primeiro capítulo, como já começamos a ver, ainda não há certeza alguma, só espera.

Temos Milan e Anna, grávida, que já não esperam mais, que já se encontram em terreno próprio mas invadido (eles são da Tchecoeslováquia mas estão em solo que os alemães reivindicam para si), na guerra ainda não declarada mas já vivida, com os postos oficiais ocupados e com uma mãe mandando a filha se esconder na casa deles porque seu pai estava nervoso e tinha se escondido com armas - e a criança, ali, na casa de Milan e Anna, sem entender nada e invejada justamente por isso.

Temos Zézette e Maurice caminhando em uma rua rica de Paris, onde ela antes vendia flores e onde ele se sentia tão constrangido diante de tantos ricos. Ele, operário, não sabia ao certo como se mover e falar nessa rua ao mesmo tempo tão cheia e sem que ninguém toque em ninguém... e enquanto ela se encanta com esse mundo bonito do qual participara, mesmo que à margem, ele compra jornal e pensa em seus camaradas, na guerra, tão distante desse mundo burguês que bem a merecia. É com alegria que sente Brunet tocar seus ombros, já que agora havia um camarada ali naquela rua, alguém que provavelmente pensaria o mesmo que ele e não teria esses olhos sonhadores de Zézette. Mas se é certo que já sabemos (devido à $A$ idade da razão) que Brunet é do PC e escreve em jornais, é certo também que ele não parece ser igual a Maurice, proletário - e é justamente isso que este percebe: "Il regarda 
Brunet et sa joie tomba tout à fait: Brunet avait de fortes mains paysannes, une dure mâchoire, des yeux qui savaient ce qu'ils voulaient; mais il portait un col et une cravate, un complet de flanelle, il semblait à l'aise au milieu des bourgeois" ${ }^{295}$. Mesmo que Brunet faça parte do PC e deseje o mesmo que Maurice, para este é claro que o primeiro é burguês, se veste bem e consegue se sentir à vontade em meio a toda aquela riqueza.

Aos poucos podemos perceber que não se trata apenas da guerra maior e burocrática, dos homens de poder enclausurados em hotéis discutindo planos e concessões - mas a guerra está em todos os lugares: entre Milan e Anna (com ele já não esperando nada e ela sim, até mesmo um filho); na criança mandada escondida para a casa deles, fugindo mesmo sem saber do que se tratava; entre Zézette e Maurice, namorados e pobres mas com olhares tão distintos sobre a rua Royale... entre Maurice e Brunet, ambos do PC, desejando uma revolução socialista, mas com o primeiro sendo operário e o segundo burguês... A guerra aparece em todos os lugares e pessoas, até mesmo na criança que nada compreendia do que estava acontecendo.

E mesmo quando se tenta evitar o conflito, ele transparece... Anna e Milan discutem, Maurice não se sente bem ao lado de Zézette, e se não diz nada a Brunet, este vai embora pensando justamente no julgamento não dito daquele: a de que no fundo ele era um intelectual, um burguês e que restaria para sempre separado dos proletários como Maurice, que ama o camarada porque lhe é natural, necessário: "Les aimer. Les aimer tous et toutes, chacun et chacune, sans distinction. Il pensa: 'Je ne devrais même pas vouloir les aimer, ça devrait se trouver comme ça, par nécessité, comme on respire"' ${ }^{296}$. Brunet sabe ser um burguês intelectual e por mais que fizesse tudo para se tornar igual a Maurice e desejar as mesmas coisas, sabe que nunca terá as mesmas angústias, as mesmas lembranças ${ }^{297}$.

\footnotetext{
295 SARTRE. "Le Sursis" In Oeuvres Romanesques - p. 745.

${ }^{296}$ IBIDEM - p. 747.

${ }^{297}$ E aqui já podemos ver algumas das reflexões de Sartre sobre a questão do intelectual e do PC, de como a situação do burguês intelectual nunca será exatamente igual à do proletário, de como ele está ao mesmo tempo dentro e fora do partido. Com esse encontro entre Maurice e Brunet em uma rua luxuosa de Paris podemos perceber bem os contrastes entre ambos e o desconforto que um sente perante o outro: Maurice diante do bem-estar de Brunet e Brunet diante da impossível união.

Isso se torna ainda mais claro quando Brunet pensa na guerra inevitável que as pessoas ainda ignoravem, na provável destruição de Paris e sente medo, deseja a paz. Logo após pensar que Zézette era uma tola que com certeza assinaria manifestos a favor da paz, é ele mesmo quem a deseja: a visão de uma Paris destruída é forte demais para seus olhos burgueses... enquanto Maurice pensa em, junto com os companheiros, destruir a rua Royale e essa burguesia parisiense, Brunet não gosta de pensar que Paris pode ser destruída.
} 
Os pequenos conflitos aparecem em todos os diálogos. Quase todos esperam por algo, por essa guerra que ameaça logo chegar e mesmo quem não espera por nada está inserido nesse cenário de medo e espera. A guerra no horizonte muda as relações até mesmo de quem ainda não se deu conta dela e faz surgir conflitos que até então podiam ser ignorados: diante da guerra, faz muita diferença ser um proletário filiado ao PC ou um intelectual filiado ao mesmo partido. E se Brunet logo se envergonha de sentir por Paris o mesmo que Zézette e as mulheres deviam sentir, é justamente para uma mulher que deseja ser homem que somos levados: é Odette quem aparece falando a Mathieu que era idiota ser mulher naquele momento.

Embora ele já tenha sido nomeado na segunda página do livro, como alguém que também esperava, é só aqui que ele realmente aparece, bronzeado, em um ambiente tão distinto daquela Paris de $A$ Idade da Razão, sufocante nos quartos e boates e museus: estamos na praia, ao ar livre, "livre" depois de tantos problemas, de Marcelle e Ivich - só, diante de uma mulher discreta, bela e inteligente, esposa de seu irmão Jacques, passando parte das férias com eles em Juan-les-Pins (como dissera a Ivich no romance anterior).

Fazendo castelo de areia na praia Mathieu conversa com Odette sobre Ivich, no quanto ele aprecia o desespero russo dela, e Odette fica com inveja dessa jovem que sabe tão bem ser infantil e enganar os homens, atrai-los. E mesmo nesse recanto de paz, de tranqüilidade, de ciúmes, é a guerra que impera e infesta o ambiente: Odette sente-se mal por ser mulher, por detestar a maneira tão segura com que os homens falam de guerra perto dela e ao mesmo tempo por exigirem um comentário que a proíbem de dar (se ela não fará a guerra, o que poderia falar para eles?), e Mathieu, que ainda pensa em Ivich, fala em escrever para ela sobre a guerra, explicando sobre a Tchecoeslováquia e o que aconteceria ${ }^{298}$.

A guerra torna todos iguais nessa espera impotente, mas se é certo que surge para todos, cada um lida com ela de modo diferente, de uma maneira particular. E talvez seja por isso que a multiplicação de subjetividades leve a uma melhor compreensão do que seja essa guerra em sua totalidade.

De Mathieu e Odette na praia em Juan-les-Pins somos transportados para outro litoral, agora ao norte da França e a outro casal que também não é casal (até agora,

\footnotetext{
${ }^{298}$ Se até agora as mulheres também só apareciam sendo vistas (Anna por Milan, Zézette por Maurice), agora é Odette quem vê essa cena. É ela quem pensa na guerra, no quão difícil é ser mulher nessa época.
} 
tirando os personagens reais, dos governos, apenas Brunet aparece sozinho ${ }^{299}$. Milan está em sua casa com Anna, Maurice caminha com Zézette, Mathieu está na praia com Odette ). Charles, em sua cadeira de rodas, aparece ao lado de Jeannine, enfermeira. Ambos conversam, e com o olhar de Charles percebemos que ele se sente uma boneca que os "em pé" levam para onde quiserem, sem nem mesmo perguntar sua opinião, um simples objeto que não poderia ser afetado nem mesmo pela guerra que ameaçava chegar.

Mas ele se engana: ironizando o tempo todo Jeannine, preocupada com a guerra, dizendo que os "em pé" estavam cansados de ficar em pé e agora inventavam essa guerra para poderem ficar agachados também, que ele era totalmente alheio às questões dos judeus e da França, espanta-se quando ela, chorando, diz que todos os doentes serão evacuados de Berck porque estavam perto demais da fronteira. Diante disso, Charles percebe que mesmo ele será atingido pela guerra. Objeto ou não, criança ou adulto, é simplesmente impossível não ser atingido por ela. Ele treme, diz que quer ficar ali e deseja, desesperado, saber quando e para onde iria... mas ela de nada sabe. Agora ele se sente ainda mais um joguete na mão dos outros, mas não mais um joguete que é indiferente ao que fazem dele: a guerra o torna um objeto que será atingido. Se até agora ficar mais ou menos tempo ao sol não modificava em nada seu modo de viver e ser tratado, a guerra consegue acentuar tudo.

Todos são ameaçados com essa guerra que começa a se fazer mais presente que o desejado. E se no início partimos de uma cidade na Tchecoeslováquia que já tem os postos oficiais ocupados por alemães, agora, depois de todo esse "tour", algumas horas ou minutos depois, ficamos sabendo, por Anna (as mulheres finalmente começam a ganhar olhar, e nem poderia deixar de ser assim, já que logo os homens as abandonarão), que os alemães já marcham nas ruas.

A tensão aumenta ainda mais, mas é alguém que não tem a menor idéia do que acontecia no mundo que agora aparece no romance. Se até as ignorantes mulheres Ivich e Zézette sabiam da guerra e queriam saber mais sobre ela, mesmo no momento em que essa guerra dá mais um passo para sua realização existem pessoas que continuam completamente à margem dos acontecimentos, por vontade ou não.

É o caso de Gros-Louis que chega em uma Marseille toda fechada e com cafés que funcionavam mas fechavam suas portas. Pastor, Gros-Louis nada entende dessa

\footnotetext{
299 e talvez apareça sozinho justamente porque nunca está sozinho, porque é o Partido, o Grupo.
} 
cidade na qual chega. Senta-se em uma praça e logo arruma companhia de um negro que explica o desfile que vêem passar (eram trabalhadores da docas que queriam recomeçar a greve)... ele diz que foi até ali para procurar um trabalho e logo ouve um homem criticar outro por este falar em sindicalismo quando estavam com a guerra no pescoço, e então pergunta ao negro "quelle guerre?".

Gros-Louis, trabalhando com carneiros, nada sabia de Marseille, da greve e da guerra... à margem de tudo que acontecia na sociedade, não recebe resposta do negro (ao menos o "diretor de cenas" deixa de relatar o encontro nessa pergunta). Voltamonos para outros personagens de $A$ Idade da Razão: vemos Daniel e Marcelle grávida caminhando por uma pequena cidade, sentando em um banco no qual Marcelle descansa (e enquanto ela descansa, Daniel fica a pensar que detestava o campo, o verde, essas coisas que faziam bem a uma grávida Marcelle, que o adorava). Ela pensa no filho; ele, no quanto ela o adora, pensa ter enfim conseguido o que desejava ("'tu l'as voulu! Tu l'as voulu! Tu souhaitais une catastrophe à la petite semaine, eh bien! tu es servi"' $)^{300} \ldots$ mas é sobre a guerra que conversam, e se Daniel a deseja, diz no entanto que não acredita que vai haver guerra. Era impossível ver a guerra nesse cenário de campo e natureza.

Mas essa paz tão presente no campo, nos animais, mostra-se cada vez mais guerra na casa de Milan e Anna: agora os alemães não só marcham nas ruas como chamam por Milan e xingam os tchecos. Milan, para se controlar e não atacar os alemães, pensa não estar sozinho; Daniel pensa estar sozinho ao ver a destruição em meio àquela paz que parecia eterna... mas é Charles quem descobre que ficará sozinho, sem Jeannine: enquanto ele viaja de trem, para não atrapalhar a guerra que os "em pé" resolveram fazer, Jeannine será transferida para um outro hospital.

Realidades tão distintas e o mesmo incômodo causado pela guerra: se ela causa raiva em Milan por estar ali em sua frente destruindo seu café, se ela é desejada por Daniel em meio à paz do interior, e se tentava sem sucesso ser indiferente ao destino de Charles, pouco importa - mesmo com significados tão diversos, ela chega e transforma, incomoda; modifica o relacionamento até mesmo dos jovens Pierre e Maud no último passeio em Marrocos antes de voltarem à França; e o pensamento sobre o que encontrariam na volta ao país não pode deixar de existir: ao mesmo

\footnotetext{
${ }^{300}$ IBIDEM- p. 771. Esse foi o modo encontrado por Daniel para se humilhar, para ser fixado por um olhar que o adora e que ele detesta, para se sentir, assim, determinado do modo como ele deseja, como aquele que se humilha e ao fazer o seu mal, faz o bem dos outros.
} 
tempo que relembram o início da viagem, há um mês, quando se conheceram, não deixam de pensar na guerra que talvez já os esperava, e embora Pierre diga não ter medo dela, pede para não falarem mais sobre isso; o que, no entanto, é impossível, ainda mais quando ele encontra um livro com fotos de feridos no rosto e aterroriza Maud, dizendo que durante todo o tempo que ela falava besteiras, coisas pequenas, ele pensava na guerra e no rosto que teria no próximo ano: ele mostra as fotos para ela e ela percebe que ele tem medo, era covarde, assim como seu antigo namorado. Mas ele a proíbe de julgá-lo, já que ela não fará a guerra. Como Odette pensara ao conversar com Mathieu, a posição da mulher nessa guerra que surge é complicada: ao mesmo tempo em que os homens desejam ser vistos como heróis, não suportam qualquer outro julgamento que elas façam.

Mathieu, do outro lado do mar, sozinho na praia, pensa no que apenas a criança e Gros-Louis ainda conseguem não pensar:

Il jeta un dernier coup d'oeil à la mer: la guerre n'avait pas encore éclaté; les gens dînaient tranquillement dans les villas; pas un canon, pas un soldat, pas de barbelés (...) Il haussa les épaules et gravit les marches de pierre: depuis quelques jours les choses le quittaient une à une. Il avait perdu les odeurs, toutes les odeurs du midi, et puis les goûts. À présent la mer. 'Comme les rats quittent le bateau qui va sombrer'. Quand viendrait le jour du départ il serait tout $\mathrm{sec}$, il ne lui resterait plus rien à regretter ${ }^{301}$.

Já é noite... 20h30 em Juan-les-Pins, 21 h30 em Praga e quase todos esses personagens esperam uma comunicação que será transmitida pelo rádio. Assim como quase todos iniciaram o dia esperando, o dia finda e a espera continua; até mesmo Milan agora espera, mesmo sabendo que tudo estava acabado. Mesmo que de modo bastante distintos, alguns indiferentes, outros com medo ou raiva ou desejo, todos esperam, quase todos são abalados por essa guerra que já se encontrava no horizonte.

E o que esperam chega: o governo da Tchecoeslováquia comunica a mobilização geral dos cidadãos em condições de se engajar. É a declaração oficial da reação tcheca aos alemães e a compreensão por todos que ouviram-na de que "em um

${ }^{301}$ IBIDEM - pp. 781 - 782. 
instante" tudo iria acontecer: a reação, o jantar, o sono, a guerra. Tudo agora é questão de "instantes"302.

É assim que o dia 23 de setembro de 1938 termina para esses personagens, em uma espera que se mostra cada vez menos espera e mais certeza. Tanto os personagens já tão conhecidos, mas agora vistos por si próprios e não mais em volta de Mathieu (Brunet, Marcelle e Daniel, Ivich, Boris que só é nomeado uma vez, Sarah que aparece nas últimas linhas chamando o filho Pablo e o marido Gomez para ouvir a música, Jacques que não aparece mas que sabemos estar em Juan-les-Pins com Odette e Mathieu), quanto os novos personagens (além dos "reais", podemos citar Milan e Anna, Maurice e Zézette, Charles e Jeannine, Philippe e Irène, Pierre e Maud, GrosLouis) esperam por essa guerra, seja desejando-a ou odiando-a... e todos giram ao redor dela, até mesmo aquele que ainda nada sabe sobre ela. $\mathrm{O}$ eixo central deixa de ser um professor intelectual burguês com seus problemas pessoais e passa a ser uma guerra que diz respeito a todos, até mesmo à pequena cidade de Crévilly, onde acordamos na manhã de 24 de setembro, sábado.

Enquanto a maioria ainda dormia ou começava a acordar, o padre Coulard tocava o sino de Crévilly, acordando a população para ser avisada da "mobilização geral" por meio de cartazes colados... e todos se põem a caminho: os camponeses em direção à cidade para se apresentarem, Pierre em direção ao navio que o levará de volta à França, e Mathieu que hesita em sair de sua cama.

Mas quando essa caminhada se desenrola, tudo se mostra diferente do que eles previam.

Os homens que saíram de suas casas para se apresentarem descobrem, depois de longo caminho e cansaço, que apenas os reservistas com fascículo 2 estavam sendo mobilizados (das 3 fichas que deveriam ser coladas, uma - a que especificava quem estava mobilizado, não tinha sido colada em Crévilly). "Ils avaient envie de rire et de se mettre en colère, ils se sentaient vides comme au lendemain de la foire" ${ }^{1303}$ : os homens que foram literalmente acordados para guerrear e se apressam para se apresentarem, talvez para não pensar muito no que faziam, descobrem agora que não estão sendo mobilizados e não sabem mais o que sentir e fazer.

\footnotetext{
${ }^{302}$ E só um negro que canta é capaz de mudar um pouco essa atmosfera pesada. Novamente a arte, a música, aparecem como instante de fuga, de abstração desse mundo tão feio e prestes a entrar em uma guerra mundial.

${ }^{303}$ IBIDEM - p. 804.
} 
E Mathieu também tem uma manhã diferente daquela que previa, totalmente previsível naquela pequena cidade no litoral sul da França, com todas as formalidades e trivialidades de qualquer cotidiano. Sai de casa antes de Odette se levantar e resolve caminhar, comprar jornal e ler um cartaz colado no muro que tanto chamava atenção de tanta gente - tudo para passar o tempo. Mas ao ler pela segunda vez o cartaz que convocava todos os reservistas com o número 2 para se apresentarem imediatamente ao local de convocação indicado, Mathieu se dá conta de que ele tinha o fascículo n. 2. "Tout d'un coup l'affiche se mit à le viser; c'était comme si on avait écrit son nom à la craie sur le mur, avec des insultes et des menaces" ${ }^{304}$. O dia, que lhe parecia tão "redondo" e já morto de antemão por velhice, mostra-se, subitamente, alongado, tumultuado, com uma outra e nova direção. E com as mesmas palavras que Marcelle usara em A Idade da Razão para anunciar a gravidez não desejada, Mathieu agora pensa na guerra, na sua mobilização e diz um "Ça y est" ${ }^{305}$.

Do mesmo modo que a morte determina e transforma todo o passado, visto agora em si mesmo e não mais como passado de um futuro (algo em que Mathieu pensara ao ir ao hotel de Lola, provavelmente morta, em A Idade da Razão, e que agora é repetido com a morte de Viguier - personagem que já aparece morto e de quem só sabemos ser um homem pacífico), a guerra também modifica os significados de todos os atos passados: se tinha um futuro pacífico, se tudo que fazia incluía esse futuro pacífico, agora, sem paz, esse futuro se mostra totalmente falso: "Nous étions appliqués et sérieux, nous essayions de comprendre et voilà: ces belles journées avaient un avenir secret et noir, elles nous trompaient, la guerre d'aujourd'hui, la nouvelle Grand Guerre nous les volait par en dessous. Nous étions cocus sans le savoir. À présent la guerre est là, ma vie est morte, c'était ça, ma vie: il faut tout reprendre du début" ${ }^{306}$.

Mathieu, pensando em seu ser-para-a-guerra, no quanto todos seus atos agora teriam outro significado, volta para casa e encontra Odette tomando café, sem ainda ter lido os jornais, e portanto sem saber que Mathieu tinha sido convocado. Sem coragem, sem saber ao certo como contar a Odette, resolve primeiro ler uma carta de Boris, que se encontrava em Biarritz com Lola, e de Gomez, que o avisava estar uns dias em Marseille e que no domingo (no dia seguinte) iria a Juan-les-Pins para

\footnotetext{
${ }^{304}$ IBIDEM - p. 805.

${ }^{305}$ IBIDEM - p. 806.

${ }^{306}$ IBIDEM - p. 808.
} 
conversar com Mathieu, que decide então adiar sua ida à guerra para segunda-feira. Enquanto pensava nisso, Odette decide ler o jornal e descobre que Mathieu fora convocado. Passado a surpresa e sabendo que Mathieu ainda ficaria 48 horas ali, Odette nada diz, e Mathieu pensa que ela foi correta ao fazer isso.

E se já haviam aparecidos tchecos (povo invadido por alemães), agora os judeus também começam a aparecer. Schalom caminha por Paris e pensa na solidariedade judia, que tentava respeitar os preceitos judeus, como não comer porco, mas que isso era quase impossível para um pobre imigrante como ele. Chega onde tinha de ir, ao judeu Birnenschatz, que se sentia mais francês que judeu e que estava diante de seu empregado que partia para a guerra e não lamentava por isso, já que os judeus estavam sofrendo tanto nas mãos de Hitler. Mas Birnenschatz detesta essa solidariedade judia e acha que faz-se mal a um homem e não a um judeu, e por isso era totalmente contra a guerra. Defender seu país, que agora era a França, era uma coisa, mas lutar para salvar um judeu alemão não fazia sentido.

É o confronto entre esses dois judeus tão diferentes, Schalom e Birnenschatz, que Sartre narra agora: enquanto o primeiro reclama de seu exílio, por ter de sair de Viena e não ter encontrado nenhuma ajuda na França além dos judeus,o segundo pensa que o outro simplesmente desconsidera que ele é francês e se no início aceita o discurso de Schalom, um tempo depois explode e diz, irritado: "je suis Français, moi, je ne suis pas Juif allemand, je me fous des juifs allemands. Allez la faire ailleurs, votre guerre" ${ }^{307}$. O outro vai embora e recusa o dinheiro, mesmo porque só aceita dinheiro de judeu e o outro não se considera mais como um deles.

As vítimas iniciais da guerra aparecem nesse livro e nunca de modo simples, definido. Assim como Milan não pensa o mesmo que Anna, os judeus Schalom e Birnenschatz pensam um o oposto do outro. E ao mesmo tempo que temos essa identificação de todos perante a Guerra que começa a surgir, as diferenças pessoais e os conflitos não deixam de existir; pelo contrário, são até mesmo acentuados - mas isso passa agora a também dizer respeito à guerra. Se Anna se irrita com Milan é pelo modo como ele quer reagir à provocação alemã, se Charles briga com Jeannine é porque ele será transportado de cidade por causa da guerra, se Birnenschatz briga com Schalom é porque este coloca a raça judia acima da pátria. É certo que as questões

${ }^{307}$ IBIDEM - p. 821. 
pessoais não deixam de ser importantes, mas agora até mesmo elas têm relação com a guerra. Marcelle grávida, por exemplo, deixa de ser uma questão só de Marcelle e Mathieu (e agora, na verdade, de Marcelle e Daniel) para se tornar uma questão mais universal: como ter um filho em meio a uma guerra mundial?

E é esse "alargamento" que vemos também com Sarah e Gomez: se em $A$ Idade da Razão víamos apenas uma Sarah bondosa que queria ajudar a todos, agora podemos perceber mágoa em relação à Gomez (de que Mathieu falava mas não percebíamos, mesmo porque Gomez não aparecia no primeiro volume). Eles estavam em Marseille com o filho, passando alguns dias juntos, alguns dias que Gomez tirara de licença da Guerra da Espanha. O encontro de Sarah e Gomez é marcado pela nãocompreensão, que se mostra principalmente no modo de educar o filho Pablo: enquanto Sarah, amante da paz, dá brinquedos de menina ao menino (sempre segundo o olhar de Gomez), ele, amante da guerra, dá armas com que o menino se diverte pelo quarto, fingindo atirar em todos os cantos, matando fascistas e franceses, o que horroriza Sarah. Ambos discutem e ela o critica por querer sempre a guerra, por não apenas guerrear mas por ser feliz assim. Gomez pensa então que não era bom com sua mulher, que lhe dava oito dias e partiria feliz para a guerra, e uns dias antes do necessário, para ainda rever Mathieu, que agora conversava com seu irmão Jacques sobre o assunto em que quase todos pensam ${ }^{308}$.

Mas se Jacques pensa que Mathieu está desesperado por ter sido convocado, este diz que não sente nem pensa em nada, que parte porque não pode fazer de nenhum outro modo e que é totalmente indiferente. Enfim, Mathieu se diz resignado (exatamente o que ele interpreta como sendo a idade da razão), e agora é Jacques quem se espanta com tamanha resignação: seu irmão tão crítico e questionador, aquele que sempre quis ser livre e para isso se recusou a casar e ter filhos, agora simplesmente aceitava uma guerra porque "era assim"!

Mathieu, tu m'étonnes. Tu m'étonnes énormément, je ne te reconnais plus. Comment? J'avais un frère révolté, cynique, mordant, qui ne voulait jamais être dupe, qui ne pouvais pas lever le petit doigt sans chercher à comprendre pourquoi il levait le petit doigt plutôt que l'index, le petit doigt de la main droite plutôt que celui de la gauche. Là-dessus, voilà la guerre, on l'envoie en première ligne, et mon révolté, mon casseur d'assiettes part

\footnotetext{
${ }^{308} \mathrm{O}$ mesmo remorso que Gomez tem por dar pouco à Sarah já foi visto na relação de Mathieu com
} Marcelle em A Idade da Razão. 
gentiment, sans s'interroger, en disant: 'Je pars parce que je ne peux pas faire autrement' $^{309}$.

Mathieu, sem querer discutir, diz apenas que nunca chegara a ter uma opinião formada sobre esses assuntos, e finge escutar quando seu irmão mostra as várias justificativas para que não houvesse guerra (os alemães do sudeto tinham todo o direito de voltar a pertencer à Alemanha, Hitler tinha seus problemas mas era um governo forte e jovem que poderia conter a URSS). Odette volta e seu sorriso, voltado apenas para Mathieu, lhe diz muito mais que todos esses discursos alterados de seu irmão, que quer, segundo Mathieu, lhe colocar a morte na alma (assim como o título do primeiro volume é dito por Jacques, agora é Mathieu quem diz que Jacques deseja a morte na alma, título do terceiro volume).

Se Mathieu reage indiferentemente, Odette com um silêncio e Jacques por um discurso nervoso, o vendedor de flores Pascal ri de todo o nervosismo que infesta os carros na rua e até mesmo Maurice, que ia anunciar a Zézette sua partida, ficava a pensar em quanto tempo teria que carregar fuzis e respeitar os capitães... pensamento totalmente distinto de François Hannequin, farmacêutico que também ia à guerra e se despede de sua mulher, ambos mais preocupados com arrumar a mala e comida que com a própria guerra. Mas Georges, também um trabalhador, tem inquietações com a guerra para a qual fora chamado - e se também pensa, assim como Hannequin, em como sua mulher ficará, angustia-se ao saber de antemão que sua pequena filha irá se transformar e muito (ao contrário de sua esposa, que fará tudo sempre igual), e talvez nem mais reconheça o pai quando esse voltar.

A indiferença de Mathieu não é semelhante à indiferença de Hannequin nem a de Georges, assim como o riso do florista não é em nada parecido com o sorriso de Odette: mesmo o mesmo sentimento diante do mesmo fato (a convocação, a ida à guerra) é sentido de modo completamente diferente por esses homens. Se a guerra se constitui um horizonte igual para todos, cada um a sente e a vive diferentemente.

E isso também pode ser visto no modo como as mulheres vêem a partida de seus homens... Odette se cala e sorri, as esposas de Georges e Hannequin mal compreendem a partida e se ocupam com as malas, talvez justamente para não pensar na guerra, e Maud teria muito orgulho se seu homem não temesse a guerra - mas ela ainda estava longe, entrando no navio no qual voltaria com as amigas da Orquestra

\footnotetext{
${ }^{309}$ IBIDEM - p. 826.
} 
para a França e no qual já sabia de antemão que teria que entregar seu corpo ao capitão para que elas pudessem mudar para uma cabine de segunda classe sem pagar a mais por isso (sempre era assim: compravam bilhete de terceira classe, e Maud, a mais nova, entregava-se aos capitães para mudar de classe).

Já Marcelle pensa no quão terrível é uma guerra, ainda mais quando carrega um filho no ventre - e por isso se espanta quando Daniel lhe diz que mesmo na guerra pode-se viver normalmente e que o terrível "c'est que rien n'est jamais bien terrible. Il n'y a pas d'extrêmes" ${ }^{310}$. Ela dorme e Daniel continua a pensar no que dissera a ela, e em sua solidão agora tão rara, acha mesmo que a guerra não mudaria em nada os homens ${ }^{311}$ :

ce soir de juin, quand il avait décidé de l'épouser, il étouffait d'angoisse, il croyait plonger dans l'horreur. Tout ça pour en venir là, au fauteuil d'osier, au goût doucement pourri du marc dans sa bouche, à ce dos nu. La guerre, ça serait pareil. L'horreur, c'est toujours pour le lendemain. Moi marié, moi soldat: je ne trouve que moi. Même pas moi: une suite de petites courses excentriques, de petits mouvements centrifuges et pas de centre. Pourtant il y $a$ un centre. Un centre: moi, Moi - et l'horreur est au centre ${ }^{312}$.

Esse homem que é ele mesmo, esse "ele mesmo" que na verdade não é "ele mesmo" (daí vem seu desejo de se coincidir consigo próprio, de ser o puro objeto de seu ódio, de ser definido como o pederasta) não se transformaria com a guerra, e era isso o fundamental. E para fugir, para ser, nem mesmo o olhar de Ralph e Mathieu eram suficientes (mesmo porque eles também necessitam do olhar de Daniel para serem): era necessário encontrar um olhar opaco, não-humano, que fosse uma plenitude de presença. É de O Olhar que Daniel precisa e é ele que encontra nessa solidão que não é mais solidão (já que ele nunca mais estará sozinho, sempre haverá esse Olhar que o vê e que ele não vê nunca).

Mas se Daniel ainda tem tempo para pensar em ser, se Maud ainda tem tempo para pensar no capitão a quem se entregará, o tempo da guerra se aproxima e torna o ritmo mais rápido, e de longos parágrafos pensativos de Maud e Daniel passamos para

\footnotetext{
${ }^{310}$ IBIDEM - p. 848.

311 se a guerra até agora é sempre vista como algo que transformará a vida de todos os personagens, Daniel pensa que ela não modifica em nada a questão do Olhar, do julgamento dos outros... e talvez se possa viver na guerra como se vive na paz, como Mathieu tão bem mostrará.

312 IBIDEM - p. 849.
} 
diálogos rápidos no caminho da despedida: Hannequin e Georges, em Saint-Flour e Niort (respectivamente) vão com suas esposas até a estação de trem, onde se encaminham para a guerra. Enquanto Mathieu ainda pode esperar 48 horas, Hannequin e Georges já preparam as malas... enquanto Maud e Daniel pensam em si mesmos, os outros dois já se encontram no trem partindo para a guerra. Aos poucos, a guerra toma um espaço cada vez maior. Se antes apenas Milan e Anna viam os alemães invadindo sua cidade e o empregado judeu via seu primo queimado pelos alemães, agora são os próprios franceses que começam a ter suas vidas transformadas pela guerra.

E não apenas os franceses que vão para a guerra: Pitteaux, jornalista da revista "le pacifiste", entra na casa da mãe e do padrasto general de Philippe, que estava desaparecido. Os pais, desesperada e irritado, mostram a Pitteaux a carta que Philippe deixara antes de sumir (que era o tempo dos assassinos e que ele tinha escolhido ser mártir) e pedem para que ele, que tanto influenciava o jovem problemático, diga onde estaria escondido. Pitteaux nega ter sido tão influente, mas diante de uma ameaça velada do general em relação à revista, promete ajudá-los caso souber de algo.

O ritmo é acelerado e a rapidez com que passamos de um personagem a outro se torna ainda maior. De Pitteaux na casa do general padrasto de Philippe passamos para Pierre, que entra em sua cabine no navio e se sente mal. Sem saber que Maud já ia se encontrar com o capitão, pensa em vê-la e pedir desculpas, mostrar que não era covarde mas que apenas estava doente.

E se o navio se dirige para Marseille, é lá que Gros-Louis se encontra, no cais, olhando os navios e saindo novamente para caminhar pela cidade em busca de comida e trabalho. Cansado, sozinho, sem achar lugar que o aceitasse para comer, pensa no negro que conhecera no dia anterior e decide procurá-lo. Encontra um bistrot e lá faz amizade com dois homens com que não se sentia muito à vontade, mas bebem juntos e Gros-Louis mostra que tem bastante dinheiro para pagar as bebidas... e quando diz que vai procurar seu amigo, o negro (o que para ele era muito fácil de achar), os dois novos companheiros o convidam para se divertir na noite de Marseille.

Quem não se diverte nessa noite que chega é Maud, já no quarto do capitão, fazendo sexo com ele, enquanto Pierre, ainda passando mal, sai de sua cabine e vai até a cabine de Maud para se desculpar e se mostrar corajoso, mas descobre que agora ela estava na segunda classe e que não estava em seu quarto. Decide então esperar perto da escada, por onde necessariamente ela passaria, e ela no quarto do capitão fazendo 
"seu trabalho" e com medo que ele não gostasse dela e a mandasse novamente para a terceira classe (ela nem se importaria com isso, o problema eram as amigas). Logo Pierre ouve um cochicho, a voz de um homem se despedindo de uma mulher e ela caminhando até chegar à escada que leva à segunda classe. Ele percebe que se trata de Maud, suada, despenteada e na segunda classe... sem o ver, ela vai até sua cabine e ele perde todo o desejo que tinha por ela, e vomita.

Enquanto o navio se encaminha para Marseille, lá vemos Gros-Louis e mais dois camaradas e uma mulher em um bar. Nosso pastor se cala e só observa os rostos, as expressões, até ver um negro bebendo no balcão. Pensando ser seu amigo, vai até lá e nada entende quando o negro diz não conhecê-lo... já arrumando confusão, os novos companheiros o salvam ao mostrar outro negro que entrava e era idêntico ao outro e idêntico ao que ele conhecera no dia anterior... Confuso, mas agradecido aos dois, sai com eles à rua, onde "Mario le poussait, Starace le tirait, ils tournèrent le coin de la rue $^{\prime 313}$.

Eles viram na esquina e deixamos de vê-los. Quem aparece agora é Philippe, tentando tirar um passaporte falso... mas era preciso esperar até a manhã seguinte para pegá-lo. Entra em um café, começa a beber e observa um proletário que diz partir no dia seguinte para a guerra. Quando este pede para brindar à vitória, o pacifista Philippe se recusa a dizer e é ameaçado pelo dono do bar e pelo mobilizado, até que cede a contragosto. Já na rua Philippe sente medo do bêbado proletário e sai correndo, mas o bêbado Gros-Louis mal tem tempo de reagir aos companheiros que batiam nele e o roubavam: cai, sangrando, na rua.

Philippe ainda tem tempo de fugir e entrar em um hotel, onde fica a pensar sobre sua vida de ontem, já tão distinta da de hoje, e no heroísmo do futuro, no mártir que será. Mas esses devaneios são cortados pelas vozes de Zézette e Maurice, no quarto ao lado, falando da guerra e da tristeza de ter que partir.

Enquanto ouve os dois fazerem sexo, pensa em salvar esses anjos tristes... Gros-Louis, bastante ferido, procura por sua sacola e vê sua carteira vazia, apenas com a caderneta militar. Enquanto todos dormem, ele procura suas coisas e chora como nunca chorou em sua vida... e os soluços que solta se parecem com os sons finais do gozo de Zézette, que acordam Philippe, decidido agora a salvar esse casal, a dizer que Maurice não deve partir para a guerra. Mas quando finalmente vai ao quarto dos dois,

${ }^{313}$ IBIDEM - p. 883. 
é preciso vê-los irritados para que crie coragem de dizer que não é preciso partir para a guerra, que se pode sempre fazer documentos falsos. Maurice, no entanto, ironiza esse jovem que se diz pacifista e desertor, perde a pouca paciência que lhe restava criticando esse rico que tinha horror à guerra, e por fim o expulsa de seu quarto com alguns socos, deixando Philippe aos prantos - enquanto quase todos os outros personagens dormem na noite desse sábado, 24 de setembro.

Se no dia 23 víamos sempre uma apreensão no ar, um estado de espera (apenas com Milan e Anna vendo o início da invasão dos alemães), no dia 24 essa espera já se transforma em caminhada, em partidas: com o anúncio do governo tcheco na noite de 23 e do governo francês na manhã do dia 24 , a espera deixa de ser espera e modifíca o caminho de muitos de nossos personagens. A mobilização é feita e os homens são convocados e precisam partir, mudando a rotina e a previsão de todos.

$\mathrm{O}$ ritmo se torna mais rápido, a câmera "treme" mais, oscila entre os personagens de forma mais nervosa... é a guerra que se aproxima. Mas mesmo com a guerra cada vez mais presente e próxima, ainda é possível ignorá-la e pensar apenas em si como Daniel, Gros-Louis e Maud faziam. No entanto, esses problemas cedem cada vez mais espaço a novos personagens que já estão mergulhados na guerra que ainda não começou (o judeu, os dois homens que já partiram e deixaram suas mulheres para ir à guerra).

E talvez não seja por acaso que Mathieu ainda espere. É certo que ele é obrigado a mudar seus programas, seus rumos e a reinterpretar seus atos passados, mas é certo também que ele não mergulha nessa convocação: para rever um amigo, decide partir 48 horas depois... esse personagem sempre adia seus compromissos e engajamentos. A guerra surge, a mobilização é feita e ele ainda consegue sorrir "à la belle nuit de lait" ${ }^{314}$.

Mas o domingo, 25 de setembro, dia de Deus, inicia-se com sangue: GrosLouis caminha por uma cidade cega aos problemas cotidianos - ninguém o olhava e o ajudava, todos pensavam na guerra e ignoravam esse homem ferido e sem dinheiro algum. Ele desejava um olhar que o ajudasse, tal como Daniel conseguira por alguns instantes o Olhar de Deus (embora oscilasse entre essa presença que tudo vê e a extrema solidão), mas é um empregador que o vê e mesmo desconfiado de seu aspecto doente e sujo, concorda inicialmente em lhe dar um trabalho, até ver sua caderneta

${ }^{314}$ IBIDEM - p. 905. 
militar e descobrir que Gros-Louis tinha sido convocado e precisava se apresentar. Este, ainda sem compreender nada (não sabia ler), volta a caminhar confuso.

Quem também caminha, mas em direção à estação de trem (o símbolo da guerra no livro), é René com sua irmã Irène (talvez a secretária do jornalista Pitteaux), é Zézette com Maurice, que encontrava companheiros e tentava se livrar da angústia de ver homens de cabeças baixas caminhando e ouvindo um barbudo gritar "Abaixo a guerra" (seria Philippe?) - ele desejava companheiros para lutar e só via homens resignados, tristes. O domingo de festa ("quand les usines sont fermées, quand les hommes sont ensemble et attendent, les mains vides, dans les gares, le sac au dos, sous un destin de fer, alors c'est dimanche et ça n'a pas tellement d'importance qu'on parte pour la guerre ou pour la forêt de Fontainebleau") ${ }^{315}$ se torna domingo de luto (o corpo de Viguier sendo preparado para o enterro).

Domingo de Deus (sofrendo na cruz para Gros-Louis, olhando para Daniel), de festa e luto, domingo em que a enfermeira Jeannine se atrasa, deixando Charles sozinho a manhã toda, até ser atendido por outra enfermeira, que o avisa que todos os doentes deveriam estar prontos para partir às 11 horas... depois de arrumado, ela o empurra na cadeira de rodas e Charles vê a fila indiana de doentes, que se preparam para partir de trem sem nem mesmo saber para onde irão (imagem imediatamente associada ao cortejo fúnebre de Viguier), e chora, dizendo ter sido muito feliz ali e Jeanninne chega correndo, a tempo de se despedir dele e de fazê-lo ficar com raiva: "elle tourna autour de la gouttière, triste et affairée, bien d'aplomb sur ses deux jambes, et il trembla de haine: c'était une debout, elle avait des souvenirs verticaux, il ne resterait pas longtemps à l'abri dans ce coeur" ${ }^{\prime 16}$. E mesmo que ela peça para ele escrever, é sozinho que entra no vagão escuro.

A raiva também estava entre Pierre e Maud, que vai procurá-lo na cabine e o encontra doente, com cheiro de vômito, mas ainda com coragem de dizer que a vira na noite anterior saindo da cabine do capitão. Maud se confunde toda: ao mesmo tempo que acha que não deve explicar nada a esse homem covarde e doente, gostaria que ele não gostasse dessa história, e ele diz não se importar nem um pouco em saber disso, mostrando, para ela, que não havia mais nada entre eles; assim como não haveria mais entre Charles e Jeannine: a guerra torna um homem covarde e outro um objeto, e

\footnotetext{
315 IBIDEM - p. 913.

${ }^{316}$ IBIDEM - p. 926.
} 
ambos se tornam irônicos e cruéis diantes desse novo papel, tentando esconder a dor e a solidão que sentem.

Charles entra no trem que partirá com os doentes e Boris, em Biarritz, observa a Lola que muitos partem do hotel em que estão. Bem diferente de $A$ Idade da razão, o jovem Boris se mostra bastante carinhoso e atencioso com Lola, que percebe, gosta, mas não compreende a razão disso (do que nós, leitores, logo somos informados: a obsessão de Boris de não atingir a velhice, de morrer jovem, aumenta - determina que viverá por mais um ano e que até lá pretende conhecer "A mulher" por meio de Lola, e lhe deixar boas lembranças. É para alimentar sua biografia de "homem de uma só mulher que morreu na guerra" que Boris muda seu comportamento).

Mas quem já está na guerra e não tem o menor desejo de ser "homem de uma só mulher" é o espanhol Gomez, que se despede de Sarah e de seu filho Pablo... ela descreve a partida de seu marido, que preferira se encontrar com Mathieu do que ficar uns dias a mais com ela, e o quanto isso a magoava. Sozinha com o filho na vazia Marseille, Sarah anda rápido sem nem pensar no filho, mas logo se sente mal ao vê-lo correndo, tão cansado e tão inocente... Diminui a velocidade de seus passos, mas se amedronta ao ver um homem andando atrás dela nessa cidade em que todos já se escondem em suas próprias casas Com medo, decide não correr e fala com esse homem que lhe sorri e faz todo o medo se dissipar. Todo machucado ainda, é GrosLouis quem pede para Sarah ler sua caderneta militar, que o condenava à guerra. Mas ela não faz apenas isso: resolve fazer um curativo na cabeça dele e o aconselha a não ir para a guerra se puder fugir.

Mas como um homem na cadeira de rodas poderia fugir? Charles, jogado naquele trem sob sol forte, descobre, pela enfermeira irritada, que também havia mulheres naquele vagão (o que causaria muito constrangimento: como ela cuidaria de um na frente do outro, principalmente em relação às fezes e urina?). Com vergonha, vê que sua vizinha é uma mulher - e começam a conversar quando o trem sai da estação, e a acha muito bela, mais bela ainda quando ela diz ser pobre.

Também no trem está Georges, não doente, mas indo para a guerra, e conversando com um novo companheiro, para quem mostra uma foto da filha.

Um trem indo para a guerra, outro fugindo dela, levando doentes no chão, que nem mesmo podiam ir ao banheiro quando precisassem. E Charles, nervoso, sente o trem parar e tem vontade de urinar, mas nada diz. Continua a conversar com sua vizinha e gosta cada vez mais dela... seguram-se as mãos e ele se sente mal ao ver a 
enfermeira com um urinol na mão dizendo "Si quelqu'un a envie, il vaudrait mieux le dire pendant l'arrêt, c'est plus commode. Surtout ne vous retenez pas, n'ayez pas honte les uns devant les autres. Il n'y a ni homme ni femme ici; il n'y a que des malades" ${ }^{317}$.

Cada vez mais Charles e seus companheiros de trem são reduzidos à condição de coisa. E se no início todos sentem vergonha, aos poucos a necessidade se mostra maior que a vergonha e eles cedem, chamam a enfermeira para urinar e assim encarnam o nada que são, o doente e não o homem ou a mulher - e até sua vizinha, com voz baixa e pedindo para ele se virar, acaba por urinar. Essa ação deixa Charles ainda mais apaixonado, orgulhoso: vendo que sua vizinha agüentou até não poder mais, decide protegê-la; mostrar-se homem e não coisa (não iria urinar). Ele, tão doente e em sua cadeira de rodas, era capaz de negar sua condição de doente a que os outros queriam condenar.

Mas se Charles tem condição de se revoltar e mostrar que é digno de ser chamado homem, de segurar as mãos da vergonhosa vizinha Catharine e de fazer amor com ela apenas tocando-a nos braços, o governo da Tchecoeslováquia não tem mais como reagir e é praticamente obrigado a aceitar as condições que lhe seriam impostas numa reunião que logo se realizaria.

No entanto, os personagens ainda não sabem dessa reunião nem das condições... Philippe continua a tentar convencer os outros a não irem para a guerra, a não aceitarem-na como se fosse uma doença, um mal necessário contra o qual nada podemos fazer (para ele, a guerra "c'est un mal insupportable parce qu'il vient aux hommes par les hommes") ${ }^{318}$; enquanto Mathieu continua a esperar (agora por Gomez, que logo chegaria na estação de trem) e a tudo aceitar (afinal, a guerra é como uma doença $)^{319}$.

Gomez chega e vai com Mathieu a um restaurante, onde falam de Marcelle e de como a vida de Mathieu não mudara em nada nesses dois anos em que eles não se viam. Mesmo que não estivesse mais com Marcelle, nada fora modificado; fazendo Gomez rir e ao mesmo tempo ridicularizá-lo (ao falar "ah os franceses são todos eternos", quer dizer na verdade, como vemos logo a seguir, que tem raiva ao ver que

\footnotetext{
${ }^{317}$ IBIDEM - p. 957.

${ }^{318}$ IBIDEM - p. 964.

319 é interessante confrontar essas duas visões da guerra com os diários de Sartre na época da guerra. Ali ele mostra como passou da idéia inicial e estóica de que era necessário suportar a guerra como uma doença que nos ataca de repente para a idéia de que a guerra não era nada de exterior aos homens, que era feita pelos próprios homens.
} 
os franceses em nada se modificam mesmo tendo uma guerra ali ao lado, na Espanha, e com outra guerra surgindo).

E se Gomez tem muito a criticar Mathieu e os franceses, este também não admira muito o velho amigo (afinal, ele fora ali buscar música e mulheres - se ele, espanhol, tem o direito de fazer isso, basta um francês fazer o mesmo para poder ser criticado)... Gomez flerta com uma mulher e ouve tango, Maud toca com as amigas no navio, Boris vai ao bar Basco e ouve às vezes a voz de Lola cantando no cassino, mas principalmente conversa com o dono do bar e outros homens corajosos que lá iam. Philippe também bebe e decide deixar à sorte sua ida ou não à guerra... sem saber mais o que é mais revolucionário (desertar ou guerrear), decide deixar a decisão para a moeda, para o puro acaso, mais ou menos como Mathieu decide deixar sua vida, sendo criticado por Gomez por isso (o pintor que não via mais motivos para pintar não podia admitir que os franceses ainda desejassem um motivo para entrar na guerra). E ao mesmo tempo que Gomez tira uma mulher para dançar, Philippe, completamente bêbado, também dança com uma negra para quem logo depois se entrega, confessando antes que era virgem, sem nem mesmo saber por que não tinha partido.

Primeira noite de amor de Philippe, última noite de Gomez na França antes de voltar para a Espanha, última noite de Charles com Catherine, sem que nenhum dos dois saibam disso. $\mathrm{O}$ trem pára em Lanoche-Migennes e a enfermeira os informa que passarão a noite ali, antes de seguir viagem. Quando Charles é carregado para fora, com medo de perder a estabilidade a qual já tinha se acostumado junto à protegida Catherine, pergunta aos enfermeiros se ela ficará junto a ele e descobre que não, que as mulheres serão separadas dos homens naquela noite e no dia seguinte, para prosseguir viagem. Ele é simplesmente depositado em uma sala para passar a noite, sem saber o sobrenome de Catherine, sem saber se conseguiria reencontrá-la. É nessa solidão e desencontro que o narrador deixa Charles e se ele não consegue dormir ao lado de sua amada, Philippe dorme sua primeira e última noite de amor com a negra, e Gomez com a mulher que encontra no restaurante e com quem dançara... e GrosLouis, sem dormir, passa a madrugada na estação de trem, esperando o horário de seu trem e sem ainda saber se realmente haverá guerra. Segurando um jornal que tudo deveria informar (o motivo da guerra, o tempo amanhã, contra quem entrariam em guerra, o horário do trem), começa a chorar por estar extremamente sozinho.

O domingo, dia 25 de setembro, inicia-se com Gros-Louis sozinho, no meio da rua em Marseille, sem nada ainda saber sobre a guerra, e mesmo que termine a noite 
ainda nada sabendo sobre ela, que continue quase tão ignorante quanto antes, sabe ao menos que foi convocado para esse guerra da qual nada compreende.

A segunda guerra mundial invade todas as cidades e cidadãos: a criança que nada compreende foi obrigada a sair da casa de seus pais e ir escondida até a casa de Milan e Anna, já em meio a um território em guerra... e agora até mesmo o simples pastor Gros-Louis, analfabeto, é atingido: também sem nada compreender, como a criança, ele é envolvido por toda essa atmosfera na qual não se pode entrar sem sair ileso.

O tempo também se apressa... do dia 26/09, segunda-feira, só conhecemos o meio da tarde, já 16h30, com um jornalista anunciando a seus colegas de trabalho que agora a guerra ia ser declarada. E com isso nem mesmo Mathieu podia esperar mais. Odette prepara (assim como as mulheres de Hannequin e Georges) comidas e bebidas para ele levar, e ele procura seu olhar, que não encontra.

L'odeur de résine emplit soudain les narines de Mathieu et, pour la première fois depuis l'avant-veille, il lui sembla qu'il y avait autour de lui quelque chose qu'il allait pouvoir regretter. C'était la paix de cet après-midi dans la cuisine, ces calmes travaux ménagers, ce soleil laminé par le sote, qui tombait en muettes sur les carreaux et, par-delà tout cela, son enfance, peutêtre, et un certain genre de vie calme et affairée, qu'il avait refusé d'une fois pour toutes ${ }^{320}$.

Enquanto Mathieu sente nostalgia e fica sentimental, de modo quase que alheio e totalmente prático Odette continua a fazer os pacotes e diz que é Jacques quem irá com Mathieu atá a estação, evitando assim qualquer contato maior com ele... mas ela não se despede apenas com um aperto de mão: ao vê-lo subir para o quarto, vai atrás de Mathieu, lhe diz adeus e o beija, sem permitir que ele a abrace.

Todos se preparam para essa guerra e para o discurso que Hitler faria no final daquele dia... mas alguns ainda esperam a paz e pensam que ela é possível: Zézette atende uma mulher que lhe pede para assinar uma petição contra a guerra (que seria entregue ao governo francês). Independente das questões sociais, as mulheres se unem (a condessa e Zézette), e tal como Brunet previra ao ver Maurice junto a sua namorada, esta assina o papel. Mas a guerra se aproxima cada vez mais. Às $20 \mathrm{~h} 20$ Mathieu já está no trem e pensa na declaração que Hitler fará em 10 minutos.

${ }^{320}$ IBIDEM - pp. $1001-1002$. 
E todos esperam por essa declaração: Jacques e Odette sentados na sala, Boris no bar Basco para ouvir e traduzir o discurso a outros homens. A guerra está em todos os lugares e ultrapassa todas as questões pessoais. Se antes dela Mathieu achava que suas dificuldades diziam respeito apenas a si mesmo, agora existe essa guerra que o ultrapassa e ultrapassa a todos; e se está em todos os lugares, se invade todas as questões pessoais, é ao mesmo tempo inapreensível em sua totalidade: "de temps en temps on croit qu'on va la toucher, sur n'importe quoi, dans la sauce d'un tournedos, on avance la main, elle n'est plus là: il ne reste qu'un bout de viande dans de la sauce. Ah! pensa-t-il, il faudrait être partout à la fois" ${ }^{321}$. Mas Mathieu sabe que é impossível se ver de todos os lugares, se ver com os olhos da guerra: todos fazem a guerra, mas ninguém a faz totalmente; ela só existe para Deus e Deus não existe. No entanto, a guerra existe!

É esse sentimento de que a guerra está em todos os lugares, que todas as pessoas a fazem sem no entanto fazê-la na totalidade, que Sartre deseja mostrar por meio de Sursis. Através da técnica simultaneísta, do artifício de mostrar vários personagens ao mesmo tempo em lugares distintos, Sartre quer ser esse Deus que não existe e para quem a guerra existe na totalidade. E para isso é necessário (ao contrário do que poderia parecer em um primeiro momento) fragmentar a escrita, a narração: através da narração feita simultaneamente em Marrocos, Juan-les-Pins, Marseille, Biarritz, Paris, Tchecoeslováquia, o que se pretende é reconstituir a guerra do modo mais "verdadeiro" possível: de modo fragmentário e confuso, sem qualquer espécie de onisciência.

A guerra está ali, em tudo, nos menores gestos, até nos gestos dos ignorantes e das crianças, que nada compreendem dela, mas justamente por isso é impossível apreendê-la em sua totalidade: por estar em todas as partes, ela foge do olhar de uma só pessoa. Por mais que ela invada totalmente esse olhar, ela o ultrapassa e ele, se só a vê, não a vê por inteiro. E se não há Deus para vê-la do modo mais completo possível é preciso multiplicar os olhares, os personagens, os lugares. É isso que Sartre faz aqui em Sursis ${ }^{322}$.

\footnotetext{
${ }^{321}$ IBIDEM - p. 1022.

${ }^{322}$ Sartre faz isso, no entanto, sem utilizar o narrador onisciente que tanto critica. É por meio da desfragmentação, dos múltiplos olhares que essa sensação de "totalidade" é dada, e não através de um narrador que tudo sabe e prevê, ligando todos os personagens e ações.
} 
Diante do discurso de Hitler, Milan se desespera (fica cada vez mais tenso), Gomez, já na Espanha, alegra-se, Philippe ainda pensa se foge ou não... com esses múltiplos olhares tão contraditórios a guerra chega e é, aos poucos, construída.

Boris conversa com outros homens no bar e quando fica sozinho, pensa no quanto esses homens são simpáticos e no quanto teve sorte: diferente de Mathieu, que nascera para a paz, ele já nasceu para essa guerra que agora explodia... essa guerra que com certeza parecia tão estranha para Mathieu, para ele era seu destino, o destino de todos os jovens de sua idade, e se angustia por saber que terá que esperar um ano para poder ir à guerra. No mesmo momento Mathieu, em Marseille, pensa com angústia nessa guerra que chega como uma doença que era preciso suportar.

E a cada dia a guerra estava mais presente e os dias mais curtos... o dia 27/09, terça-feira, começa às $22 \mathrm{~h} 30$, com Mathieu chegando em Paris, no seu apartamento que agora mal reconhece como sendo seu, e decide não dormir lá, voltar apenas na manhã seguinte, quando encontrará Ivich lá.

Nessa noite, no entanto, ela ainda estava em Laon, na casa dos pais, ouvindo as notícias pelo rádio, junto ao pai, que lhe diz que a situação está muito ruim e que se houver guerra, os alemães invadarão a França e destruirão Paris, o que deixa Ivich desesperada a pensar na cidade em que vivera, no que tão bem conhecia e no que ainda não conhecera. Decide então ir à rua, onde tudo estava, onde tudo acontecia, não precisamente em Laon, mas em Paris, para onde iria fugir nessa terça que já acabava.

Mas essa Paris que Ivich tanto ama e tem medo que seja destruída já não é tão significativa para Mathieu: "Mathieu avait traversé la rue Cels, la rue Froidevaux, suivi l'avenur du Maine et même la rue de la Gaîté; elles se ressemblaient toutes: encore tièdes, déjà méconnaissable, déjà des rues de guerre. Quelque chose s'était perdu. Paris n'était déjà plus qu'un grand cimetière de rues" ${ }^{\prime 23}$. Mesmo os bares tão freqüentados e conhecidos tinham se modificado: poucos clientes, hora para fechar e bebida que é preciso pagar na hora... e era ali nessas ruas e bares que Mathieu decidira passar sua última noite em Paris antes de chegar à cidade na qual deveria se apresentar.

Nessas mesmas ruas Irène passa sua noite, entediada com as pessoas tão bem vestidas que a rodeavam e até com seu amigo Marc, que desejava tê-la naquela noite (o que para ela era ridículo diante de Hitler que talvez os atacasse no dia seguinte).

${ }^{323}$ IBIDEM - p. 1043. 
Quando percebe Philippe, que freqüentava o escritório de seu patrão Pitteaux, na rua, decide deixar Marc no bar e fugir, perseguindo esse jovem que estava sendo procurado pelos pais; e ao ir atrás dele, o vê louco, gritando "abaixo a guerra" pelas ruas.

Ivich nas ruas de Laon, Philippe e Irène nas ruas de Paris, próximos de onde Mathieu também caminhava, pensando no quão nada era:

Dehors. Tout est dehors: les arbres sur le quai, les deux maisons du pont, qui rosissent la nuit, le galop figé d'Henri IV au-dessus de ma tête: tout ce qui pèse. Au-dedans, rien, pas même une fumée, il n'y a pas de dedans, il n'y a rien. Moi: rien. 'Je suis libre', se dit-il, la bouche sèche. Au milieu du Pont-Neuf, il s'arrêta, il se mit à rire: 'Cette liberté, je l'ai cherchée bien loin; elle était si proche que je ne pouvais pas la voir, que je ne peux pas la toucher, elle n'était que moi. Je suis ma liberté'. Il avait espéré qu'un jour il serait comblé de joie, percé de part en part par la foudre. Mais il n'y avait ni foudre ni joie: seulement ce dénuement, ce vide saisi de vertige devant luimême, cette angoisse que sa propre transparence empêchait à tout jamais de se voir ${ }^{324}$.

É ao descobrir que tudo estava fora, que ele não era nada, que Mathieu se descobre livre... essa liberdade que tanto procurara nos acontecimentos, mostrava-se agora como sendo ele próprio. Ele, nada, era sua própria liberdade - e se achava que se sentiria feliz quando essa liberdade chegasse, agora, ao descobrir que ela é nada, sente angústia e vertigem. Mathieu sente o peso absurdo desse absoluto: "Hors du monde, hors du passé, hors de moi-même: la liberté c'est l'exil et je suis condamné à être libre" ${ }^{325}$.

Assim como a guerra é uma doença a ser suportada, a liberdade é uma condenação diante da qual é necessário... fazer o que? O que fazer com esse peso insuportável? Agir! Jogar-se nessa água, ato que nada poderia impedir (diante da "horrível liberdade" não há impedimentos); mas se nada o impede de jogar-se, nada impede o contrário. Mathieu desiste e volta a caminhar pelas ruas, enquanto Ivich corre à estação para fugir até Paris, onde Philippe continua a gritar "Viva a paz" até ser espancado por alguns homens e socorrido por Irène que o seguia e por Mathieu,

${ }^{324}$ IBIDEM - p. 1057.
${ }^{325}$ IBIDEM - p. 1058. 
que ouvira os gritos e decidira, sem razão alguma, ajudar o jovem (passando-se por policial e mandando os rapazes embora antes que resolvesse prendê-los por agressão).

Estamos agora diante de um Philippe machucado junto a Irène e Mathieu, que revela não ser um policial, e os coloca em um táxi. Irène pede para ele acompanhá-la, já que Philippe tentava se jogar do carro e ela, sozinha, não conseguia segurá-lo. Os três chegam na casa de Irène (com uma breve conversa no carro, ela já sabendo que ele fora mobilizado) e os dois colocam Philippe para dormir. E enquanto este começa a dormir, Mathieu e Irène vão ao quarto dela e sem muito se falarem, fazem sexo.

Outro casal que faz sexo é Boris e Lola, e de um modo tão diferente de alguns meses antes que Lola começa a acreditar que ele a ama. Mas se Mathieu partiria na manhã seguinte, Boris só partiria em um ano (o que é angustiante para ele e para Lola, e por motivos opostos: ele por ter que esperar ainda um ano, e ela por saber que ele partiria de qualquer modo daqui a um ano). Ele ainda tenta explicar a ela que, embora fosse antimilitar, era na verdade contra os oficiais e não contra os soldados, e que se não lutasse, nunca saberia se agüentaria os golpes ou se teria medo. Sem falar para ela, diante dessa angústia de ter que esperar mais um ano para poder se provocar, saber como iria reagir, Boris decide se engajar voluntariamente na manhã seguinte.

Dia 28 de setembro, às 6 da manhã, Mathieu acorda (assim como nos dias $24 \mathrm{e}$ 25 , voltamos à manhã, enquanto nos dias 23, 26 e 27 já começávamos o capítulo à tarde ou à noite) e Ivich já se encontra em Paris, indo para o apartamento de Mathieu, que para lá também se encaminhava (antes, porém, ele descobre que Philippe tinha fugido da casa de Irène).

Ivich chega primeiro e encontra o apartamento aberto, mas vazio. Mathieu logo chega e a vê ali. Ele conta a ela que logo partirá e ela conta que fugira de casa... ambos tratam de questões práticas, como o apartamento e o dinheiro que ele lhe dará, até enquanto não voltar. Mas ela deseja principalmente saber onde fica a Tchecoeslováquia, razão de toda essa guerra, e ele mostra para ela em um mapa (no qual, na verdade, nem havia o país. Ele o desenha onde mais ou menos o país foi criado, após 1914). Despedem-se ali mesmo e se ela aceita o dinheiro que ele dá, é apenas para rasgá-lo assim que ele sai. Boris também sai do quarto onde Lola ainda dormia para ir à polícia se engajar na guerra um ano antes do necessário; e é à polícia que Philippe também vai, e para se entregar (por ser desertor e ter feito passaporte falso). 
Já tivemos o dia da espera, dos caminhos, das despedidas... e hoje parece se o dia da entrega: Mathieu entrega-se à Irène e à guerra, Boris antecipa sua mobilização e Philippe se entrega à polícia.

Mathieu se encontra com Irène e ambos vão de táxi até a estação, pensando no quão longe estava a noite anterior... esses dois desconhecidos que compartilharam apenas uma madrugada, agora compartilham um dos momentos mais delicados da vida de um homem: a ida à guerra. Eles se abrançam e se despedem quase sem se falarem, e Irène só agora pergunta o nome de Mathieu, que responde e entra no trem para Nancy. Ela também se entrega a esse homem que mal conhece, assim como Ivich se entrega a um jovem que detestava para não morrer virgem, e como Daniel se entrega a Mathieu em uma carta que esse começa a ler no trem e não termina.

Do mesmo modo que em $A$ Idade da Razão Daniel escolhe Mathieu como confidente, não por confiar nele mas justamente para humilhá-lo por meio da confissão, para fazê-lo cúmplice de algo que o diminui. Em uma carta, da qual só conhecemos um trecho (o trecho que Mathieu lê), Daniel deseja contar uma aventura extraordinária que lhe acontecera, e se quer contar, é para que ela lhe pareça mais real. Confessa que em junho passado, quando lhe revelara um "aspecto de sua personalidade", compreendera que "on ne pouvait s'atteindre que par le jugement d'un autre" $^{326}$ e que por ver Mathieu como o mediador dele a si mesmo sentira uma certa gratidão.

Mas agora, viajando com Marcelle, deu-se conta da reciprocidade das relações entre eles: "s'il est vrai que je ne puis m'atteindre sans ton intercession, la mienne t'est nécessaire si tu veux te connaître" ${ }^{327}$. Se o olhar de Mathieu tinha sido suficiente quando Daniel dissera ser pederasta, agora esse olhar não basta, já que Mathieu, para se conhecer, também precisa do olhar de um outro, do de Daniel. Agora era necessário um outro olhar, um olhar que não pudesse ser olhado, que só poderia ser sentido: e Daniel sentira esse olhar de Deus: "Ah! Mathieu, quelle découverte: on me voyait, je m'agitais pour me connaître, je croyais m'écouler par tous les bouts, je réclamais ton intercession bienveillante et, pendant ce temps-là, on me voyait, le regard était là, inaltérable, un invisible acier" ${ }^{328}$.

\footnotetext{
${ }^{326}$ IBIDEM - p. 1096.

${ }^{327}$ IBIDEM - p. 1096.

${ }^{328}$ IBIDEM - p. 1097. O inferno, definido pelo mesmo Daniel em A Idade da Razão, que era ser visto, passa a ser denominado por Deus. É o olhar de Deus, e não do Diabo, que tudo vê, que tudo fixa, e é ele o inferno que tanto atrai Daniel e do qual ele tanto foge.
} 
Daniel descobre que o olhar de outro homem era insuficiente para fazê-lo ser, já que o ser desse "olhar" também dependia de outros olhares, do próprio olhar de Daniel... mas o olhar de Deus tudo vê e não é visto, é capaz de dar um ser total a Daniel sem que seja necessário qualquer confissão. Mas quando ele começa a relatar na carta sua ida à igreja e conversa com um padre, Mathieu para de ler e joga os papéis pela janela, com apenas um pensamento: "Que velharias"... o filósofo que lê sobre o olhar absoluto, que pensara uns dias antes na guerra que estava em todos os lugares e justamente por isso era inapreensível (pensamento totalmente análogo ao olhar inapreensível de Deus), desconsidera tudo que Daniel escrevera, talvez justamente por vir dele, talvez por estar indo à guerra e nada ser importante diante dela, nem mesmo o pensamento que ele mesmo tinha há pouco tempo atrás.

Daniel se entrega à Mathieu, mas este não aceita a entrega. Outra entrega que também não dá certo é a de Philippe: os policiais o reconhecem como o filho desaparecido do general e decidem avisá-lo que o filho se apresentara, dizendo ser desertor (quando na verdade nem tinha sido mobilizado) e portar documentos falsos (que não tentara usar em nenhum momento). E o general, para dar uma "lição" ao filho, pede para deixá-lo na delegacia até o momento em que decidisse buscá-lo.

Mais à noite, às 18h30, Jacques e Odette sentam em frente à rádio, exatamente como fizeram na noite anterior ao ouvirem o discurso de Hitler. Mas hoje é Daladier quem falará, o primeiro-ministro francês. E Jacques, assim como Boris, tinha certeza que a guerra seria declarada.

Mathieu, já na guerra ainda não declarada, observa seus companheiros no trem, homens em relação a quem se sentia atraído, mas que achavam-no um tanto orgulhoso. Eles jogam cartas e bebem, enquanto Mathieu apenas olha. Mas todos começam a olhar quando um deles percebe aviões que voam alto em torno do trem, sem nem mesmo saber se eram aviões franceses ou alemães, se a guerra já havia sido declarada ou não. Diante desse desconhecimento, a paranóia surge: esses homens começam a discutir e um violonista grita que a guerra fora declarada.

No mesmo momento Daladier começa seu curto discurso, para avisar que o governo alemão convidara Mussolini, Chamberlain e ele para um encontro no dia seguinte em Munique e que ele continuaria a fazer tudo para preservar a paz. Quando todos se entregam à guerra ou aos outros por causa da guerra, é a França que parece se entregar à Alemanha para conseguir a paz. 
Lola, alegre, não entende o pavor de Boris, que então confessa ter se engajado durante a manhã por três anos. Os homens que estavam no trem, porém, ainda nada sabiam desse discurso, e alguns, desesperados, já se jogam do trem e saem correndo pelos campos, fugindo. $\mathrm{O}$ trem, no entanto, diminui a velocidade até parar em uma estação numa cidade qualquer, onde são recebidos por uma multidão que sorria e gritava "É a paz", e por uma empregada da estação que gritava que Daladier partia para Munique para a conferência de paz.

Se todos esperavam a guerra, é a paz que é anunciada. A multidão festeja na estação de trem, Jacques e Odette dançam e tomam champagne, Zézette confirma a notícia com sua vizinha e sai cantando feliz... mas há também contratempos e constrangimentos causados pela paz: Odette se mostra nervosa (se ela soubesse disso, não teria beijado Mathieu), Boris fica pálido por saber que não haverá mais a guerra para qual ele fora destinado, Philippe não entende a alegria dos policiais nem mesmo o riso seco de seu padrasto, o general que lhe anuncia que não pode existir desertor se não há guerra e sim paz. Philippe chora e Charles, em sua cadeira de rodas, não quer se alimentar. Como Mathieu, o que Charles pensa é "ils m'ont traîné hors de chez moi, emporté comme un clois, crevé, et ils ne se battent même plus. Mais il n'était pas en colère: c'était loin, tout ça" ${ }^{329}$.

De certo modo, todos esses personagens foram tirados de suas casas, transportados e tudo isso para não haver a guerra. Toda a espera, os caminhos percorridos, as despedidas e preparações, todas as entregas se mostram agora inúteis. Foram esperas, caminhos e entregas para uma guerra que não mais haveria; e agora, com a paz, tudo o que acontecera naquele mesmo dia parecia longe, distante.

A espera passa a ser, nesse momento, pela certeza da paz, pelo acordo de Munique, que acontece entre os dias 29 e 30 de setembro.

E do mesmo como Ivich se encontrava na cama, sendo tocada a contragosto por um homem, sendo estuprada, a Tchecoeslováquia teria que se entregar, entregar boa parte de suas terras para a Alemanha: em nome da paz, Inglaterra e França forçavam a Tchecoeslováquia a ceder, sem nem mesmo poder protestar. Assim como Ivich não dormia mas também não resistia ao homem que a estuprava, o governo tchecoeslovaco ainda existia mas era totalmente desconsiderado pelos alemães, ingleses, franceses e italianos: a guerra ou a paz não dizia mais respeito ao país

${ }^{329}$ IBIDEM - p. 1117. 
invadido - a esse cabia apenas aceitar o que os outros países tinham decidido, cabia apenas ser estuprado sem nem mesmo poder gritar.

Foi nisso que consistiu o acordo de Munique assinado em 29/09/1938, ao menos no modo como Masaryk, do governo tcheco, relata a reunião com os outros governantes, que simplesmente perguntam a ele o que ele poderia fazer de diferente senão assinar o acordo, obedecendo aos desejos de Hitler... se à Ivich ainda resta dizer um "eu te odeio" inútil, ao governo da Tchecoeslováquia nem isso resta, ele é obrigado a calar-se e a garantir a paz aos outros, mesmo que na prática isso significasse a invasão da Tchecoeslováquia. Esse é o sursis que tanto alegra os franceses: a paz ao mundo e a guerra à Tchecoeslováquia.

No entanto, essa paz ainda não é totalmente paz, está permeada pela ameça da guerra que sumiu mas que deixa marcas: Gros-Louis é avisado por um soldado que não haveria mais guerra, que a paz tinha sido assinada, mas ao tentar ir embora de onde tinha se apresentado, é impedido por outros soldados. A paz assinada não leva à liberdade dos soldados, mas também não alivia a vergonha dos homens que não iriam lutar e nada podiam falar sobre ela. (M. Birnenschatz, o judeu que era contra a guerra, diz a sua filha sentir vergonha por esse declaração de paz).

Mas se os soldados não podem ainda voltar para casa, se eles são obrigados a permanecerem mobilizados, eles podem, porém, pensar novamente em suas casas, nas mulheres e rotinas que os aguardam. É isso que Georges faz ao conversar com Mathieu e falar de sua filha e de sua esposa, com quem não se entende muito bem. Se enquanto eles estavam em casa pensavam na guerra, agora, mobilizados, podiam pensar em suas casas. E é por poderem novamente pensar na paz que Gomez, de novo em meio à guerra da Espanha, já perdida, detesta ainda mais os franceses que comemoram e voltar a ficar felizes ${ }^{330}$.

Até Mathieu, cuja vida talvez se modificasse com essa mobilização, com a descoberta de que a liberdade era ele e que nenhuma situação o constrangia, volta a pensar em seu apartamento e nas aulas que voltaria a dar: "Et rien ne se serait passé. Rien du tout. Sa vie l'attendait; il se coulerait dedans sans faire d'histoires - personne ne ferait d'histoires, personne ne ferait allusion à l'entrevue de Munich, dans un mois

\footnotetext{
${ }^{330}$ Sartre oscila entre um francês pensando na paz e outro que sente vergonha, um que tenta se libertar da guerra e não consegue, e outro que pensa na família. Talvez para mostrar que mesmo que muitos franceses comemorem o Acordo de Munique, ainda resta um mal-estar: felizes por não ter que guerrear, mas ao mesmo tempo incomodados por fugirem de uma guerra que talvez soubessem não ser evitável.
} 
tout serait oublié - il ne resterait plus qu'une petite cicatrice invisible dans la continuité de sa vie, une petite cassure: le souvenir d'une nuit où il avait cru partir à la guerre" ${ }^{331}$.

Todos esses dias tensos nos quais tantas vidas se colocaram em xeque não serão mais do que uma "pequena cicatriz invisível", uma lembrança de uma noite na qual eles tinham certeza de que a guerra viria. Ao menos é o que Mathieu, Georges e muitos outros pensam nesse dia seguinte ao acordo de Munique; ao menos é o que admitem pensar.

Mas logo depois de Georges e Mathieu quem nos aparece é Milan e Anna, na Tchecoeslováquia, na certeza da invasão alemã e na destruição de suas vidas... Para esses, o acordo de Munique significava exatamente o contrário do que para os franceses: para estes, a não intromissão nos assuntos de outros países, e portanto a paz; para aqueles a certeza que os outros países não mais os ajudariam e que portanto seriam invadidos e aniquilados. Para Milan e Anna agora a guerra é mais certa que nunca, e diante disso não há como imaginar uma criança nascendo, em Anna, grávida, tendo a criança. Embora ela não tenha a mesma certeza de Milan, também diz que talvez tivesse sido melhor se ela tivesse perdido a criança.

Novamente temos a questão de ter ou não um filho, tal como vimos com Mathieu e Marcelle em A Idade da Razão. Mas não se trata mais de questões pessoais, de um homem que pretende preservar sua liberdade e pensa, sem consultar de verdade sua amante, que esse filho e um casamento poderiam ameaçar seu status de homem livre. Agora estamos diante de um casal que não coloca realmente em questão a realização de um aborto, mas apenas sonha que talvez fossem melhor se essa criança tivesse sido naturalmente abortada e não nascesse nesse mundo invadido, estuprado, demolido. Mesmo Anna, a mãe, vendo a Alemanha tendo cartas brancas para invadir e destruir suas terras, e principalmente vendo seu marido bebendo o quinto copo de álcool e tremendo, pensa que talvez seria melhor se essa criança tivesse sido abortada.

Mas não foi; ela nascerá na Tchecoeslováquia invadida e destruída, de um pai dividido entre a ira e a auto-destruição, de uma mãe sem pátria e sem marido... É isso que os ingleses determinaram à Tchecoeslováquia, e é por isso que Daladier, ao voltar para a França e ver os franceses comemorando e gritando "Viva a paz", os olha e diz, entre os dentes, "os bestas, idiotas".

${ }^{331}$ IBIDEM - p. 1132. 
O que os franceses comemoram com tanta festa e alegria é a destruição da Tchecoeslováquia e um poder cada vez maior à Hitler.... o preço a ser pago por essa paz é muito alto, e eles ainda fingem não se dar conta disso, ainda se permitem pensar, mesmo que constrangidos, na volta ao lar e à rotina da paz. Mas se até mesmo Mathieu, o professor de filosofia, consegue pensar que essa noite de mobilização será esquecida, será apenas uma lembrança longínqua - mesmo que pense isso de modo ambíguo, talvez sabendo que nada era tão simples assim -, os leitores sabem muito bem que esse Sursis tem hora certa para acabar e que ele não durará muito. Para quem lê Sursis em 1945, ano de sua publicação, é claro que esses pensamentos franceses não poderiam de modo algum evitar o avanço alemão e uma segunda guerra mundial.

Mas se a guerra está tão presente desde o início do romance até o final, sua presença seria suficiente para concluirmos que enfim a história é significativa para o personagem principal?

Como já vimos pelos romances de Malraux, não basta narrar acontecimentos próximos aos reais para fazer do romance um romance histórico. Se em todos os seus romances a história aparecia e era facilmente verificável (as revoltas na Indochina nos finais da década de 20 e início de 30), o modo como os personagens principais lidam com essa história não é histórico: eles são completamente indiferentes ao destino de suas ações, às conseqüências de seus atos revolucionários. Se agem e se a história é real, coletiva, eles não o fazem por se importarem com as causas dos atos nem com as transformações que eles trarão: os personagens de Malraux agem abstratamente, buscando pela ação negar o que há de histórico e fraco neles, para confrontar o destino e se colocarem como absoluto (mesmo que essa tentativa sempre fracasse, é isso que fazem).

E se em $A$ Idade da Razão essa questão não era colocada de modo tão forte, já que o tema era Mathieu e sua liberdade abstrata diante de uma amante grávida e um filho não desejado, em Sursis isso se modifica: a história surge com mais força, com bastante importância, com personagens reais que aparecem em torno das negociações de uma segunda guerra mundial (Hitler, Chamberlain, Horace Wilson, governantes de Tchecoeslováquia e Daladier).

A possibilidade de uma nova guerra mundial parece modificar em tudo a vida de nossos personagens, tanto dos que já acompanhávamos no primeiro romance quanto os que aparecem apenas nesse segundo tomo: Mathieu sai de suas férias 
tranqüilas em Juan-les-Pins para se entregar à guerra, não sem antes se envolver com uma desconhecida que encontrara na rua ${ }^{332}$, Odette cria coragem e beija seu cunhado Mathieu, Ivich foge da casa dos pais e se entrega a um homem que odeia para poder morrer em Paris e não virgem, Boris passa a amar Lola e assim por diante ${ }^{333}$. E mesmo em relação aos novos personagens, que aparecem apenas em Sursis, podemos ver algumas modificações trazidas entre o início do romance e a confirmação de que a guerra se daria em instantes (Charles se torna mais dócil, tenta negar sua condição de objeto a que os outros tentavam relegá-lo, Gros Louis se apresenta, mesmo que continue ignorante, à guerra, Philippe muda de posição o tempo todo, é o pacifista que em alguns momentos acredita que é mais revolucionário ir à guerra que fugir dela, etc).

De um certo modo podemos dizer então que a guerra é importante não só como cenário no romance mas que também modifica a vida dos personagens, que esses se transformam por meio da história, já que as ações que eles realizam nos mostra uma diferença no modo como se relacionam com os outros e consigo mesmos. A história, a guerra que ameaça surgir e depois ameaça desaparecer definitivamente, parece transformar nossos personagens e portanto ela não está no romance apenas como um cenário indiferente.

Mas, por outro lado, essas transformações todas que vemos ao longo do romance não são fundamentais a ponto de modificarem os personagens. Se Mathieu não continua em suas férias, não é porque deseja agir, fazer algo, mudar a concepção de liberdade abstrata que, se não ousava mais defender, também não ousava abandonar: ele vai para a guerra assim como dava aula, assim como continuava com Marcelle, de modo totalmente indiferente. Se Brunet vai à guerra também não é por nenhum outro motivo senão pelo fato dele ser do Partido Comunista... se Boris dá mais atenção a Lola é porque aumentara sua certeza de que não queria envelhecer e que portanto logo morreria e era preciso tratá-la bem, conhecer todas as mulheres através de uma só mulher... Ivich volta para Paris, fugindo, assim como tantas vezes no primeiro volume se embriagava para esquecer-se de seu fracasso nos exames escolares.

\footnotetext{
332 como não contrapor essa ação ao início de $A$ Idade da Razão, quando Mathieu se sente mal por não mais conversar com estranhos?

${ }^{333}$ Muitos personagens agora realizam atos que não fariam se não estivessem às vésperas de uma guerra mundial.
} 
Mesmo que a guerra torne alguns atos mais urgentes (a coragem de Odette de beijar Mathieu vem do fato dele ir para a guerra, dela talvez não vê-lo mais), parece que essas tantas modificações não passam de transformações superficiais, que, se mantém uma relação clara com o cotidiano dos personagens, não os altera fundamentalmente.

Daniel mostra, ao dizer que é possível viver em uma guerra exatamente do mesmo modo como se vive na paz, revela a maneira pela qual Mathieu age: se descobre que era nada e estava condenado a ser livre, se sente a angústia dessa liberdade que era ele mesmo e não algo que esperava cair de um céu que não mais existe, ele em nada modifica seu modo de viver e ver os acontecimentos. Continua a agir indiferentemente, a estoicamente (como convém a alguém que está na "idade da razão") aceitar o que lhe acontece, a pensar que a guerra é como uma doença que ataca e não como algo que o próprio homem faz (o que Philippe já sabe). Do mesmo modo que a gravidez de Marcelle parecia não dizer respeito a Mathieu, a guerra também parece ser algo que não lhe diz respeito, parece ser algo externo e indiferente. Se antes ele recusava o filho e agora vai à guerra não é porque antes era indiferente e agora não: Mathieu vai à guerra exatamente da mesma maneira como não queria o filho, indiferentemente - negando ou não o acontecimento, ele parece não se inserir realmente, concretamente nele.

Como diz o próprio Sartre em uma entrevista dada em dezembro de 1945, depois da publicação de A Idade da Razão e Sursis,

Mathieu incarne cette disponibilité totale que Hegel appelle liberté terroriste et qui est véritablement la contre-liberté (...) Il n'est pas libre parce qu'il n'a pas su s'engager. Il ne s'est pas engagé vraiment à l'égard de Marcelle, puisqu'il n'a pas su construire avec elle une vie pour deux. Il ne s'est pas engagé dans la guerre d'Espagne, sous pretexte que ce n'était pas son entreprise. Mais il n'y a pour moi d'entreprise que si je commence à faire (...) Mathieu, c'est la liberté d'indifférence, liberté abstraite, liberté pour rien. Mathieu n'est pas libre, il n'est rien, parce qu'il est toujours dehors ${ }^{334}$.

A história, tanto em A Idade da Razão quanto em Sursis, onde ela aparece de forma mais forte, modificando até mesmo o modo de narrar o romance, continua sendo vista de modo indiferente para a maioria dos personagens. "Le Sursis, comme

${ }^{334}$ SARTRE. Oeuvres Romanesques - p. 1915. 
L'âge de raison, est donc le roman de l'échec, l'échec d'une societé vélléitaire, vivant sous l'emprise du marasme, de la duperie et de la mauvaise foi. Une société incapable de créer les conditions de sa délivrance et de sa liberté" ${ }^{335}$.

Talvez só mesmo em meio à guerra, lutando com e contra outros homens, a história apareça de modo essencial, não apenas como cenário, e assim seja vivida pelos personagens.

E se mesmo com uma narrativa totalmente distinta de $A$ Idade da Razão, com vários outros personagens, com um contexto bastante diferente apesar da proximidade temporal (apenas três meses depois), a história continua a ser mero cenário (mesmo que passe a ser um cenário mais importante, com mais detalhes, com maior interação com os personagens), será que a arte continua a ser vista do mesmo modo?

Não temos em Sursis muitos momentos em que a arte aparece, assim como já vimos em A Idade da Razão: se no primeiro volume tínhamos um ou dois capítulos nos quais a pintura e a música apareciam, aqui a arte também aparece em alguns poucos momentos, e de forma fragmentada, sem muita importância: Sarah chama Gomez e o filho para ouvirem um negro cantar, depois o mesmo Gomez deseja ir a um restaurante que tivesse música, e junto com Mathieu ouve um tango, e Maud toca com suas amigas no navio.

Esses são os únicos momentos em que a arte aparece em Sursis e não se fala realmente dela. Sarah apenas chama-os para escutar o cantor, logo após o governo tcheco anunciar a mobilização geral, e diz ser lindo ouvi-lo. Gomez escuta um tango com Mathieu e diz que se tocassem isso na Espanha os músicos seriam atingidos por pedras. E Maud, se toca no navio com as amigas, é apenas para cumprir o trato para mudarem de um cabine de terceira classe para uma de segunda.

Nos pouquíssimos instantes em que a música surge, os personagens parecem ver nela um momento de pausa, de calma. Se o governo tcheco anuncia a mobilização e todos ficam preocupados, com a certeza de que a guerra logo aconteceria, o clima tão pesado é nuançado pelo homem que canta: ele permite alguns instantes ainda de esquecimento da guerra, da história sangrenta que ameça surgir. E o mesmo acontece quando Gomez ouve o tango: não era possível ouvir música em meio à guerra da Espanha, mas ali, nos instantes de folga numa França em paz, a arte ainda era possível, o colocar-se acima e fora da história ainda era uma possibilidade. A arte

\footnotetext{
${ }^{335}$ CHIHEB. Esthetique romanesque chez Malraux et Sartre - p. 481.
} 
parece ser a nota de pausa antes de retornar a tocar a melodia. Continuamos, portanto, a ver uma arte que, se aparece ainda muito pouco, aparece como possibilidade de fuga e beleza diante da realidade feia de uma provável guerra.

Tanto a história quanto a arte continuam aqui a se mostrar como contrárias, uma permitindo o esquecimento da outra. E se, como já vimos, essa não é a teoria sartriana da arte (se o momento da imaginação impede ao mesmo tempo qualquer percepção, ele é um movimento que se volta para a percepção; não possibilitando, assim, uma fuga total), seus personagens de A Idade da Razão e Sursis ainda tentam não se inserir na história e vêem na arte a possibilidade, mesmo que momentânea, dessa fuga tão abstrata - assim, eles se mostram como personagens negativos, que não espelham a teoria de seu autor.

Diferente dos personagens de Malraux, que parecem pensar a arte de modo semelhante ao que o autor pensa (de acordo com seus textos mais teóricos), agora trata-se de uma teoria que não encontra ecos na narrativa: os personagens não se relacionam com a arte do mesmo modo como Sartre pensa o papel da arte; e por isso podemos dizer que, se no primeiro caso temos uma certa coincidência entre o que é narrado e o que é pensado (arte como tentativa de abstração e fuga), agora estamos diante de uma narração que contraria o que é pensado - e que por isso, essa arte como abstração, que é vivenciada pelos personagens, mostra-se, na verdade, como uma concepção negativa do autor: para Sartre, trata-se de criticar essa concepção de fuga pela arte, de ironizar os que ainda pensam, em meio à guerra, buscar refúgio na arte: se essa possibilita uma fuga, é apenas uma fuga momentânea, que logo se volta para o mundo do qual se tenta fugir.

É o que começamos a ver também na próxima narrativa, que se dá em meio à segunda guerra mundial.

\section{C) Com a Morte na Alma}

Se entre A Idade da Razão e Sursis passavam-se só alguns meses, entre o segundo e o terceiro volume temos uma separação de mais de ano, de setembro de 38 a junho de 1940, quando já estamos no início da segunda guerra mundial. Não era essa porém, a idéia inicial de Sartre. Anunciado com o título de La dernière chance, o romance cobriria um período de 6 anos, de 1938 a 1944, da segunda guerra até a 
Libertação, o que se mostra bastante complexo na época em que o escreve, em torno de 47, 48, com uma distância maior em relação aos fatos narrados. E

s'il avait pensé, avec le troisième et dernier tome des Chemins de la liberté, aborder, en plongeant ses personnages dans la résistance, l'étape positive, constructive de leur entreprise de libération, il découvre, au fur et à mesure que le temps passe, uns situation extraordinairement brouillé, où les problèmes de la liberté ne se posent plus comme sous l'occupation en termes de choix tranchés: résister ou collaborer, abattre des Allemands au risque de faire fusiller des otages, parler ou ne pas parler sous la torture, etc. Le problème moral reste le même, c'est celui des implications pratiques du choix en faveur de la liberté, mais il s'est politisé et, par là-même, dans une situation politique complexe et ambigüe, il a perdu son caractère d'alternative extrême entre la vie et la mort, l'héroïsme et la lâcheté, pour se retrouver chargé de toutes les ambigüités et incertitudes de l'après-guerre. Comment, dans ces conditions, continuer un roman qui a été expressément annoncé comme devant conduire ses protagonistes à l'héroïsme, sans verser dans la littérature édifiante, la simple commémoration de la résistance? ${ }^{336}$.

Esse terceiro volume é publicado apenas em 1949, 4 anos depois dos outros dois volumes, que foram publicados simultaneamente em 45. E para o leitor de Com a Morte na Alma, nada mais natural que passar da certeza da paz, garantida em 38 pelo Acordo de Munique (ao menos era ali que o livro anterior terminava), para a certeza da guerra. Mas não é na França invadida pelos alemães que iniciamos esse terceiro romance: é em Nova Iorque, de manhã, em um sábado, 15 de junho de 1940, que acordamos com Gomez nessa cidade plena de calor e suor.

O espanhol imerso na Guerra da Espanha desde A Idade da Razão, que voluntariamente saíra da França abandonando mulher e filho para lutar contra as forças de Franco, agora encontrava-se nos EUA, longe dos problemas e turbilhões da Europa em meio a uma guerra mundial. Se antes Gomez criticava os franceses por eles nunca entrarem em uma guerra, agora que os franceses não têm mais como pensar na paz, é ele que se refugia, que deseja encontrar um emprego de jornalista e esperar pela fuga de Sarah e Pablo para os EUA. É nessa manhã de sábado que Gomez descobre, por meio de Ritchie, que Paris tinha sido invadida pelos alemães, e sem notícia da mulher há 15 dias, espera que ela tenha conseguido fugir... e se ao mesmo

${ }^{336}$ SARTRE. Oeuvres romanesques - p. 1871. 
tempo deseja saber sobre a guerra, ler os jornais, sente prazer ao ver que os franceses perdiam a guerra, as cidades, justo eles que nada fizeram para ajudar a Espanha. Enquanto Gomez sente prazer pela derrota francesa, Sarah e Pablo caminham, refugiados, ainda na França.

Temos aqui mais ou menos a mesma técnica apresentada em Sursis, mas de modo bem mais ameno: se no segundo volume nada separava a mudança de um personagem para outro, se ficávamos confusos pela excessiva multiplicação de visões, aqui em Com a Morte na Alma temos sempre indicada a passagem de um personagem a outro. Se nessa primeira parte do romance ainda temos múltiplos personagens (o que não acontece mais na segunda parte, dedicada apenas a Brunet), temos bastante claro quando é um ou outro personagem: as ações são divididas com sinais (*) ou espaços e a indicação do tempo e lugar também sempre são fornecidas.

Muitos dos personagens a que fomos apresentados em Sursis não aparecem mais, e boa parte da confusão presente no outro livro também some. Ainda temos vários personagens, mas as experiências vividas não são mais confundidas; é por isso que é indicado claramente quando passamos da manhã em Nova Iorque com Gomes para a tarde na França com Sarah e Pablo. Enquanto o amante da guerra se alegra ao ler que Paris tinha sido invadida e sofria com o calor inumano dos EUA, Sarah sofria por ver que a gasolina do carro que a levava para Gien com o filho acabara. O homem que recebera dinheiro para levá-la até a cidadezinha de onde seria mais fácil fugir anuncia que não tem mais combustível e que não os levará até o destino final, gerando assim uma cena absurda (na qual ele briga com ela e exige o dinheiro sabendo que isso para nada servirá nesse momento).

A $24 \mathrm{Km}$ de Gien Sarah se encontra sozinha e a pé com seu filho Pablo, esperando os carros passarem para começar a caminhar na estrada em meio à multidão sofredora e alienada. Sem querer ser igual a eles, decide ajudar os outros e percebe que eles não querem ajuda: carrega então seu filho no colo, abdica de toda generosidade e se torna igual aos outros, besta no meio da tropa. "Personne n'avait d'espoir, ni la vieille, ni les deux nuques au chapeau melon, ni le couple qui poussait un tandem aux pneus crevés. Mais nous sommes pris dans la foule et la foule marche et nous marchons; nous ne sommes plus que des pattes de cette interminable vermine. Pourquoi marcher quand l'espoir est mort? Pourquoi vivre?"337. Mas se Sarah se

${ }^{337}$ SARTRE."La mort dans l'âme" In Oeuvres Romanesques - p. 1154. 
pergunta isso enquanto caminha com o filho na multidão, basta ver aviões surgindo no céu, sentir a ameaça da bomba que não cai, para concluir que era preciso voltar a viver e a caminhar.

Diante desse medo e solidão os problemas de Gomez, que voltamos a acompanhar, parecem pequenos. Embora também seja uma questão importante e fundamental (o que pode a arte quando milhares estão sendo mortos?, questão essa que o próprio Sartre se faz e que pode ser feita em relação à sua trilogia), ela não tem a amplitude do problema de Sarah (e a conclusão a que Gomez chega é justamente essa).

Após conseguir emprego e ter dinheiro adiantado, Gomez vai com Ritchie ao Museu de Arte Moderna. O pintor que abandonara sua pintura para lutar na Guerra da Espanha tenta, agora que essa guerra acabara, voltar-se para a pintura novamente, mas logo compreende que não conseguiria mais; e não só por questões práticas (o que escrever sobre arte em um jornal estadunidense se eles, como Ritchie dizia, não querem saber das questões complexas e profundas que a arte pode e deve fazer), mas também por não saber se ainda acredita na arte... e quando vê quadros de que gosta, sente-se cego (pronto, portanto, para se tornar um crítico): depois de 4 anos sem ver quadro algum e principalmente depois de ter matado, era-lhe impossível enxergar a arte, que transformava em beleza o sofrimento ${ }^{338}$. Depois de estar em uma guerra e ver o sofrimento nos olhos dos outros, de senti-lo em seu próprio corpo, como cogitar a beleza em todo sofrer? Que pode a arte perante a dor e medo de Sarah?

Crente de que seria bom crítico por não mais poder pintar, Gomez continua a ter raiva dos franceses que nunca tinham ajudado a Espanha e não compreendia esses estadunidenses sempre tão otimistas, que não queriam ser perturbados pelas questões profundas que a arte faz e que caminhavam como se não houvesse uma guerra no outro continente. Era preciso encontrar franceses, e para isso entra em um bar que esses freqüentavam. Pede um uísque e conversa com um francês, oferecendo-lhe bebida pela invasão de Paris (para lamentar isso mas também para zombar dos covardes franceses)... mas diante do velho francês triste, que logo diz que os franceses

\footnotetext{
338 essa questão do que é a arte e de como ela "funciona" em épocas de guerra e terror são essenciais para Sartre, que coloca na boca de Gomez algumas frases sua (que a pintura deve ser tudo, que a arte justifica o sofrimento tornando-o belo), sem no entanto compartilhar inteiramente de seu desânimo e abandono da arte. Quando escreve Com a Morte na Alma, Sartre ainda pensava que a arte tinha um papel essencial para o desvendamento do mundo e compreensão da paixão inútil que todo homem é... só mais tarde é que Sartre dirá que não acredita mais que a arte tenha esse poder, tornando-se talvez, esse Gomez com quem ele não se identifica no momento da criação.
} 
não ajudaram os espanhóis, os dois brindam à Espanha e à França e se sentem semelhantes: "Il n'a pas levé le doigt pour défendre Barcelone; à présent Barcelone est tombée; Paris est tombée et nous sommes tous les deux en exil, tous les deux pareils" $^{\prime 339}$. Sozinho, chora no bar.

No dia 15/09/1940 somos apresentados ao casal Gomez e Sarah, ele em Nova Iorque e ela na França, uma judia tentando fugir com seu filho e ir ao encontro do marido que talvez nem a queira mais, que encontra emprego em um jornal e bebe por raiva dos franceses e ao mesmo tempo por saber que Paris fora invadida.

E quem aparece um dia depois dessa invasão de Paris, no domingo de 16/06, é Mathieu, junto a seus companheiros de uma guerra já perdida. Com a capital invadida, a guerra já estava perdida... mas esses civis em uniformes militares continuavam ali, sem saber se serão liberados, se partirão ou se serão presos pelos alemães. Depois de nove meses de mobilização (exatamente o tempo de uma gestação), Mathieu pensa que não tem mais futuro, que tem apenas tempo a matar junto com esses sete outros homens (Schwartz, Nippert, Longin, Lubéron, Charlot, Pinnete, Pierné), mesmo que for apenas para dormir em céu aberto e ouvir bronca do tenente, que insistia em conservar a hierarquia.

Se Gomez estava em Nova Iorque e Sarah fugindo para o interior, Mathieu é o primeiro que aparece em meio à guerra, não na invadida Paris, mas como militar que se encontra em uma guerra na qual ainda não lutara mas que parecia estar no fim. Mais que saber se partiriam ou não, todos esses 8 homens pensam na prisão, no que acontecerá com eles presos: "Ils étaient nerveux et mous, indignés en faiblesse, avec ce teint plombé qui est particulier aux indigestions. Il avait suffi d'un roulement de tambour à l'horizon pour que la grande vague de la guerre s'effondrât de nouveaux sur eux $^{\prime 340}$. Da ignorância em que estavam, passavam rapidamente da tranqüilidade ao desespero, do riso ao grito, da esperança à indiferença, à certeza da prisão. Eles ainda não tinham lutado nem sido feridos, mas o terror da prisão aumentava com o passar do dia; sentimento esse que Boris, em Marseille, às 14 horas, não conhecia.

Ferido em Sedan em maio, estava triste por ter sobrevivido e ter vários anos ainda para viver. Seu projeto era morrer nessa guerra, jovem e herói, mas ele sobrevivia a ela. No entanto, ainda havia uma chance de morrer: um companheiro the faz uma proposta tentadora, a de fugir para Londres no dia 18 para lá continuar a lutar,

\footnotetext{
${ }^{339}$ IBIDEM - p. 1167.

${ }^{340}$ IBIDEM - p. 1180.
} 
a resistir. E embora essa idéia o agrade muito, Boris diz a Francillon que espera Lola chegar de Paris e então perguntará o que achava, se ela autorizava sua partida (pensando, no entanto, que obviamente ela não iria permitir).

Enquanto pensa, Ivich chega e se mostra o contrário de como aparecia em $A$ Idade da Razão, envelhecida depois de um aborto involuntário. Depois de se entregar a um homem que odiava porque Paris e ela seriam destruídas naquela noite (o que não aconteceu), Ivich ficara grávida e esse homem se casara com ela, e enquanto lutava, ela morava com seus sogros ricos que a paparicavam. No terraço de um café, os dois irmãos conversam e Boris nota, com tristeza e raiva, que não tem mais a compreensão da irmã, que eles não se entendem mais. Diante da irmã que conta seu cotidiano tão burguês e sua ira por ter vindo à França e não ter continuado na Rússia, Boris diz amar os franceses, que os viu lutar corajosamente e que não sabe mais o que fará quando for desmobilizado, o que aconteceria logo.

Passam a falar então do futuro, de como Ivich detesta seu marido e sogros, e diante de mais uma mulher frágil e dependente dele (assim como certamente Lola também se mostraria), Boris diz então que será professor em uma cidade, casará com Lola e trará Ivich para morar com eles. Não é possível abandonar duas mulheres indefesas e dependentes, e por isso ele iria sacrificar-se, sacrificar seu desejo de morrer, mas enquanto fala em se casar, pensa no avião partindo para Londres.

Quem provavelmente vai partir são os oficiais de Padoux, cidade em que Mathieu estava: eles começam a queimar seus papéis e cartas. Os oito soldados nada sabem, apenas vêem o fogo queimando algo, e é com pesar silencioso que descobrem, por Lubéron, que o cessar-fogo havia sido assinado naquela manhã: "pas un bruit, pas un souffle d'air, le temps s'était figé, la guerre s'était retirée: tout à l'heure ils étaient en elle, à l'abri, ils pouvaient croire encore aux miracles, à la France immortelle, à l'aide américaine, à la défense élastique, à l'entrée en guerre de la Russie; à présent la guerre était derrière eux, close, parfaite, perdue" ${ }^{341}$.

Fim da guerra, o armistício, talvez com condições duras, talvez com olhares hostis a esses soldados de 40 que perderam a guerra, mas é finalmente o fim. Alguns riem e logo a briga começa, com um acusando o outro (o que era pacifista sendo acusado de não ter lutado, este acusando os outros de quererem a guerra e terem perdido). Mathieu se irrita, grita e depois se culpa por isso, já que não tinha o menor

${ }^{341}$ IBIDEM - p. 1202. 
direito de julgar ninguém e muito menos de se sentir superior. Como sempre, Mathieu parece continuar à margem de tudo, de todos os acontecimentos. Ao invés de vivê-los, ele pretende ver os outros vivendo. Se em A Idade da Razão ele via a gravidez de Marcelle e tudo que desejava era apagar seu nome dessa história, em Sursis também vemos algo parecido: Mathieu é chamado à guerra e pensa em como os outros o verão, como Ivich e Odette e depois Irène vão reagir. Em poucos momentos nosso "lúcido" personagem se encontra realmente sozinho diante de uma ação que lhe concerne (como quando corta a mão, rouba o dinheiro, cai no chão, vê o cartaz da mobilização geral); na maior parte das vezes esse solitário vê os outros agindo e reagindo aos acontecimentos que lhe dizem diretamente respeito.

Do mesmo modo que os companheiros, Mathieu se irrita e se põe a gritar... contra a irritação deles. Entre a vergonha e a cólera, escolhe a última e sai a caminhar, quando então é alcançado por Pinette e os dois começam a conversar sobre a guerra que houve e que eles perderam e na qual nem mesmo atiraram, o que angustiava o jovem Pinette. Sem se sentir causador da guerra, ele não desejava ser o perdedor dela. Diz não votar, ter tido uma vida difícil demais para ter tempo para pensar na política, mas Mathieu é duro com ele, o critica por não ter tentado mudar a situação pelo voto, coisa, aliás, que ele confessa também não ter feito: essa guerra que Pinette aceitava como algo impossível de combater, que o próprio Mathieu pensava no início ser uma doença que o atacava, aparece agora, para o personagem filósofo, feita à imagem de cada um e que todos a merecem.

Do mesmo modo que Philippe pensava em Sursis, a guerra agora aparece a Mathieu como feita pelos homens para os homens. Não há nada de exterior ou inevitável na segunda guerra mundial: ela foi feita a cada gesto que esses homens ensaiavam, a cada palavra dita ou silenciada. Talvez tenhamos aqui a compreensão de que mesmo a passividade é um compromisso, de que o não votar é se comprometar com a política do mesmo modo que votar, de que não é possível não escolher. "Se ninguém é culpado, ninguém é inocente. Pessoalmente, nada tenho a ver com a guerra porque não fui eu quem a declarei. Mas se decido participar dela, mesmo de forma aparentemente anódina, como faz Mathieu, ela me concerne e eu a escolhi" ${ }^{342}$.

Diante dessa constatação, Mathieu sente novamente vontade de agir: "s'enforcer dans un acte inconnu comme dans une forêt ${ }^{343}$. Un acte qui engage et qu'on

\footnotetext{
${ }^{342}$ SILVA, Franklin Leopoldo e. Ética e literatura em Sartre - p. 152.

${ }^{343}$ tal como o personagem Claude em La Voie royale de Malraux?
} 
ne comprend jamais tout à fait" ${ }^{344}$. Mathieu sente agora que é hora de agir. E o que faz?

Do mesmo modo como nos outros dois livros, quando ele corta inofensivamente a mão e pensa em se jogar no Sena sem o fazer, o que Mathieu agora faz é dizer que não há nada a fazer, pelo menos no momento. Se a ação lhe parece necessária, ela só aparece assim quando também parece impossível de ser realizada... e diante disso, Mathieu novamente se resigna e volta a falar com Pinette sobre a esposa deste. Como diz $\mathrm{Chiheb}^{345}$, o romance mostra a questão de quando nada mais se pode fazer e quando justamente é preciso fazer algo.

Mas quando voltam onde os companheiros estavam, encontram um jovem que ria deles e confessa ter mentido a Lubéron sobre o armistício, que fizera isso apenas para se divertir um pouco mas que nenhum cessar-fogo havia sido assinado. E se era Mathieu quem pensava em agir e dizia não ser possível nessa circunstância, é Pinette quem se transforma com a nova velha notícia e afirma que isso muda tudo, que agora ainda tem tempo para lutar, para realmente entrar nessa guerra.

E se os lugares continuam espalhados (Marseille, Padoux, Gien, Nova Iorque), Paris até agora não tinha aparecido: o centro da história em A Idade da Razão, lugar importante em Sursis, invadida em Com a Morte na Alma, ela ainda não tinha surgido... e quem se encontra nessa cidade tão esvaziada e cheia de medo é justamente Daniel, o personagem que nunca aparece muito (ao menos não tanto quando Mathieu), mas que sempre é fundamental para a trama dos romances.

Daniel reaparece agora em Com a Morte na Alma em uma Paris vazia, deserta, que se escondia dentro das casas, que provocava medos noturnos em pleno dia... é nessa cidade que caminha e pensa que tudo passa a ser permitido, até gritar "viva os alemães" (porque ninguém ousaria brigar e também porque seus testemunhos, Mathieu, Brunet, deviam agora estar presos ou mortos).

Enquanto olha os vencedores orgulhosos passarem ao lado do Sena, pensa no Reino do Mal que começa, no mal que com certeza os alemães farão aos franceses e que tanto atormenta Mathieu e os camaradas, em Padoux, que agora também se esconde (a partir do momento que os alemães entram em Paris, a guerra está perdida e todos se escondem, refugiam-se em suas próprias casas), em que até uma criança mostra ter medo desses soldados perdidos.

\footnotetext{
${ }^{344}$ SARTRE. "La mort dans l'âme" In Oeuvres Romanesques - p. 1212.

${ }^{345}$ Cf. CHIHEB. L'esthétique romanesque chez Malraux et Sartre.
} 
Mathieu vê os comandantes entrarem na casa do médico e os soldados ficarem na rua, sem saber mais o que fazer, e sabendo que os soldados que caminhavam sem os oficiais pelas estradas podiam ser mortos a qualquer momento pelos aviões alemães, e que os que ficavam na cidade causavam, se não medo, ao menos desconfiança por parte da população (a jovem que trabalhava no correio afirma isso ao amado Pinette e a Mathieu). Sem muita saída, continuam ali, sem nada fazer. E quando Mathieu é acordado por Pinette, descobrem juntos que os oficiais fugiam, pegavam os carros e o resto de combustível que ainda havia, e iam embora, escondidos, sem nem mesmo avisar seus soldados, que espiavam. Esses pobres e agora desamparados soldados se reúnem no meio da rua e começam a chorar, a mostrar a grande solidão na qual se encontravam.

No dia seguinte, Mathieu caminha pela cidade e vê que "des soldats se promenaient à pas lents, seuls ou par petits groupes: ils ne savaient que faire de leur liberté $^{346}$... entram na escola, na igreja, na prefeitura, fingem ler ou bebem. Mathieu mesmo não sabe mais o que faz e se põe a escrever seu nome em uma árvore, mas logo desiste e só deseja que os alemães cheguem o mais rápido possível, o que não ocorre. Pinette vai se encontrar novamente com a moça do Correio e Mathieu fica a conversar com Charlot, aterrorizado com a idéia de que os alemães o prenderiam (o que eles fariam com um judeu como ele?), mas é Longin que chama atenção, o homem que não bebe e que se encontrava totalmente bêbado, pedindo para Mathieu tirá-lo da prefeitura, transformada agora em bordel.

Mathieu ali entra e vê esses soldados se destruindo, alegres, e com Longin que agora não queria mais sair dali. Enquanto espera o outro se decidir, vê livros atrás de um armário envidraçado mas se recusa a quebrar o vidro, o que faz os soldados bêbados rirem do moralismo excessivo de Mathieu.

Ele é ridicularizado por querer se manter sério e respeitar as leis mesmo quando todos estavam ali, abandonados, sem ter o que fazer e só pensando na prisão... por isso talvez Longin, justamente quem o chamara para levá-lo dali, diga que não ame Mathieu e que não quer mais sair. E quando o filósofo recusa-se a beber vinho com os demais, separa-se ainda mais deles, mostra-se ainda mais superior e portanto desprezível.

${ }^{346}$ SARTRE. "La mort dans l'âme" In Oeuvres Romanesques - p. 1237. 
Mathieu ne savait plus que faire de lui-même: il était entré sans penser à mal, pour porter secours à Longin. Mais il aurait dû prevoir que la honte et le scandale entreraient avec lui. À cause de lui ces types avaient pris conscience d'eux-mêmes; il ne parlait plus leur langage et pourtant il était devenu sans le vouloir leur juge et leur témoin. Elle lui répugnait, cette bassine pleine de vin et d'ordures et, en même temps, il se reprochait cette répugnance: 'Qui suis-je pour refuser de boire quand mes copains sont soûls?' 347 .

Mas não adianta: de modo algum Mathieu consegue se aproximar desses companheiros que estão na mesma situação que ele. Só o fato de pensar que não deve julgá-los já nos revela o quanto se encontra separado deles: para ele era necessário pensar ser igual aos que se consideram, naturalmente, iguais, e é isso que todos aqueles homens bêbados, muitos já jogados ao chão, percebem: eles desafiam Mathieu a beber do vinho, e nem mesmo quando aceita e bebe ele se torna um igual.

Bebendo cada vez mais, é visto agora pelos outros como alguém que quer mostrar que agüenta melhor a bebida, o que ele nega, sem adiantar. Longin continua a dizer que não o ama e que os companheiros também não o amam, já que nem mesmo quando se embriaga ele faz como os outros... a tentativa de Mathieu de se sentir um "igual" não dá certo e com raiva ele joga sua tigela no vidro que tanto não queria quebrar e grita não conseguir ficar bêbado. E ironicamente, é justamente ao desistir de ser um igual que Mathieu se torna um deles, consegue ao menos o silêncio respeitoso no lugar do escárnio... Ainda irritado, tira Longin dali à força e o ajuda a vomitar. Desiste desses companheiros e procura Pinette, a quem acompanha em um "passeio pelo campo" com a moça do correio.

Quem também passeia é Daniel pela Paris solitária, ou melhor, quase solitária: um jovem olhava as águas do rio silenciosamente, sem perceber que Daniel o olhava, tão belo e já se mostrando morto... E quando deixa de pensar nas esperanças, sofrimentos e vergonhas que tinha antigamente (as quais não voltariam, já que com a França violada tudo era permitido), o jovem quase se joga mas percebe o olhar de Daniel e se põe a fugir, mas aquele, com desejo, persegue-o. Durante a conversa cheia de atritos, de rasteiras e desafios, Daniel anuncia ao jovem que se ele contasse sua história talvez o deixaria morrer. Mas nada é tão simples assim: Daniel não deseja apenas consolar esse triste e solitário jovem, mas também fazer-lhe mal, ver o medo

${ }^{347}$ IBIDEM - p. 1253. 
em seu olhar (e por isso oscila entre o "homem que não o deixará morrer, que o escutará" e o "homem que não se importa com nada e lhe daria um veneno para se matar"). E o jovem, que agora revela seu nome, Philippe (o pacifista de Sursis que tentara fugir e depois se entregara à polícia e ao padrasto general), aceita as regras impostas por Daniel.

Em uma Paris deserta, dois homens se encontram e se põem a jogar. Daniel, o pederasta maduro, sente desejo por esse Philippe jovem, belo e desamparado... e como ambos gostam de literatura e drama, passam a andar até a casa de Daniel. Enquanto caminham, ainda sem nada conhecer de Philippe, começa a deduzir pela roupa cheirando a naftalina, pelo medo e solidão do rapaz, o que ele fizera e por que queria se matar:

Tu ne me connais pas, mais je te connais, lui dit-il. Je peux te la reconter, ton histoire (...) Tu étais dans les armées du Nord, la panique s'est mise dans les rangs et tu as décampé. Après, plus moyen de retrouver ton régiment, je suppose. Tu est rentré chez toi, ta famille avait mis les voiles et toi tu t'es habillé en civil et tu es allé droit te jeter dans la Seine. Ce n'est pas que tu sois spécialement patriote mais que tu ne peux pas supporter l'idée que tu es un lâche ${ }^{348}$.

Desse modo Daniel decifra Philippe, de quem já sabíamos ser pacifista e ter tentado em vão convencer alguns a não irem para a guerra. O jovem confessa, com seu silêncio e espanto, que Daniel adivinhara boa parte de sua história, e resolve entrar em sua casa, onde bebem uísque, acariciam os gatos e falam de Philippe, de sua mãe que ele não encontrara e do quão difícil é ser pacifista em uma família cujo padrasto é general, e um general que adora ser ativo.

Mas se o jovem diz ter o complexo de Édipo e odiar o padrasto, Daniel o provoca, perguntando se não seria do padrasto que ele seria enamorado, provocando risos em Philippe, que confessa ter medo dele e o pederasta prediz (como um "amador de almas") que fisicamente ou não o general possui Philippe e que seria necessário se livrar disso por meio de Rimbaud, da destruição por atos, da descida ao inferno - e o que restar de tudo isso, será Philippe. De certo modo, podemos dizer que esse "método" que Daniel propõe a Philippe é bem semelhante ao que ele fizera com Mathieu em $A$ Idade da Razão. Embora sem qualquer espécie de atração física, de

${ }^{348}$ IBIDEM - p. 1267. 
desejo, Daniel quer conduzir Mathieu a esse inferno, à destruição... sem ser pelos mesmos motivos e fins, Daniel novamente quer destruir o outro e se destruir junto com o outro (como com Marcelle), talvez buscando assim o olhar definitivo e desprezível de Deus.

Outro jovem que começa a ceder às regras do outro é a moça do correio, que vai passear com Pinette e Mathieu ${ }^{349}$. Sentam no campo e também começam a jogar o jogo da conquista (na guerra perdida é preciso conquistar alguém?), observados por Mathieu, que também exercia um papel (o de dar credibilidade a Pinette e segurança à jovem).

Alguns outros soldados aparecem e descansam nesse domingo que é todos os dias (sem chefes, sem saber o que fazer, só resta esperar, descansar até a chegada de outros comandantes ou, mais provavelmente, dos alemães). Mathieu percebe o casal sumir por entre o mato e sai de perto, sentindo-se totalmente sozinho nessa noite em meio ao campo... mas logo lembra-se de Charlot, sozinho na cidade, fingindo ler e apavorado por ser judeu. Mathieu decide conversar com ele e o encontra no mesmo lugar, do mesmo jeito, imóvel frente ao livro que finge ler. E se pensa em ajudá-lo, logo ouve que isso é impossível, que ele precisaria ser judeu para compreender o medo que Charlot sente.

Ao mesmo tempo que há uma imensa solidão, impossibilidade de comunicação, surgem gestos que exprimem mais que tudo isso. Não com a mesma força e intensidade que vemos nos livros de Malraux; mas aqui há também espaço para a fraternidade e a compreensão silenciosa: quando esses soldados vêem seus comandantes fugirem, eles compreendem a solidão e sorriem um ao outro; quando Mathieu caminha sozinho de volta à cidade e encontra um homem, eles se olham e nada é preciso ser dito. Se por um lado a solidão é absoluta, a compreensão se faz também bastante presente: "Ils n'avaient rien d'autre à se dire et le promeneur s'en alla. Mathieu le suivit du regard; faut-il donc que les hommes aient tout perdu, même l'espoir, pour qu'on lise dans leurs yeux que l'homme pourrait gagner?"350.

A noite ganha a cidade em que Mathieu estava e também a desamparada Paris, a casa de Daniel, na qual Philippe, cada vez mais bêbado, ainda se encontrava. E se Daniel pensa no melhor momento e modo de se aproximar do jovem, este começa a

\footnotetext{
349 até agora vimos Gomez em Nova Iorque, Sarah fugindo para Gien, Boris e Ivich em Marseille... mas a partir do momento que Daniel aparece, a narração parece oscilar entre ele e Mathieu.

${ }^{350}$ IBIDEM - p. 1283.
} 
bocejar e quer dormir. Daniel o deixa, não sem guardar consigo a chave da porta do apartamento, e vai a seu quarto, cansado de representar o príncipe do mal, cansado a ponto de não sentir mais angústia, de saber de antemão que sofrerá sem esperança e com tédio.

É a última aparição de Daniel, jogando sem sucesso, indo dormir e percebendo o Olhar que nunca é visto. O homem que desenvolve a trama em A Idade da Razão e que em Sursis anuncia o Olhar que tudo define e paralisa, agora aparece em Paris conversando com Philippe, o jovem que queria se matar mas ainda não tinha chegado ao inferno (talvez justamente o Olhar de Deus), ao qual Daniel o levaria através da destruição feita pelos atos e não pelas palavras.

Mas se ele pensa nos sofrimentos futuros, é o sofrimento presente que a cidade de Padoux vê ao longe: a cidade de Roberville queimava. Sem saber se eram os franceses ou os alemães que fizeram isso, os cidadãos e os soldados discutem e vêem alguns homens chegarem, uma quinzena de franceses com fuzis e um tenente que vai até a prefeitura da cidade sem quase nada dizer.

Mathieu, que junto com os outros via a chegada dos franceses armados, é chamado pela moça do correio, que pede para convencer Pinette a não se juntar com esses novos soldados que iriam guerrear. Pinette sugere a Mathieu conversarem ali perto mas sem a moça. Na verdade não era uma conversa que ele queria, mas um pretexto para conseguir fugir da moça, que já o sufocava. Pinette confirma que aqueles homens iriam lutar ali na cidade e que o tenente aceitava outros homens, desde que eles trouxessem fuzis com eles. E era o que ele faria, sem dúvida alguma: pegam um outro caminho para fugir da moça sem nome do correio e para buscar armas. Ao mesmo tempo que as mãos de Pinette estão geladas, há decisão demais em sua voz e Mathieu já vê seu amigo morto, matando alemães mas com certeza sendo morto depois, o que Pinette não vê: para este trata-se de um recomeço.

Mathieu diz que ele é que deveria lutar, por já não ter razões para viver, por ter se enganado desde o começo, e Pinette o convida para também guerrear, mas o filósofo parece novamente evitar qualquer ação e recusa, não se vê morrendo, ainda pensa naquela liberdade abstrata que tanto defendia em A Idade da Razão: "Casser, détériorer, ça n'est pas une solution; un coup de tête, ce n'est pas la liberté" ${ }^{351}$. No entanto, quando já se encontram na escola para pegar um fuzil, Mathieu decide agir e

${ }^{351}$ IBIDEM - p. 1300. 
pega também um fuzil, decide lutar. É a primeira vez que ele realmente age, que não se contenta com ações infantis (o corte na mão) ou que servem para fugir das responsabilidades (o roubo do dinheiro para o aborto).

Mas se esse ato nos parece ser tão importante, temos de deixá-lo com seu fuzil e ir ao encontro de seu irmão Jacques e Odette, que fugiam de Paris e procuravam lugar para passar a noite.

Aos poucos e de modo intermitente, outros personagens voltam a aparecer. Assim como em A Idade da Razão, Mathieu é novamente o personagem principal dessa primeira parte, mas os outros personagens que aparecem não estão mais em volta deles, pensando apenas nele: a partir de Sursis, eles têm vida própria e embora com menos importância que Mathieu, aparecem por si próprios. Aqui vemos Jacques e Odette sozinhos, tentando sem sucesso arrumar um lugar para dormir no meio do caminho. É Odette quem vê a situação, que relata toda sua angústia de estar ali com o homem que não mais ama e que pede sua opinião apenas para criticá-la depois. Nesse longo caminho de Paris a Juan-les-Pins, Jacques representa o papel do homem que foge para melhor proteger sua esposa, e Odette, com muito sofrimento, também representa seu papel de mulher fraca e grata pela proteção do marido.

Enquanto Jacques se mostra seguro, certo de que os alemães irão se comportar bem, é Odette quem mostra-se insegura, com medo de Paris ser destruída... na verdade a insegurança é dele mas é ela quem precisa dar voz aos sentimentos que ele tem mas não tem coragem de o dizer. Ela sabe disso e fala as palavras necessárias para que ele se sinta o protetor e ria dos medos que ele mesmo tem. Com medo de desprezá-lo por obrigá-la a fazer esse papel, Odette cede:

Je ne veux pas. Je ne veux pas lui dire ce qu'il veut me faire dire. Qu'est-ce qui me restera au monde, si je le méprise? Elle fit un pas en arrière. Il fixait sur elle un regard d'acier, il avait l"air de dire: 'Dis-le. Mais dis-le donc!' Et de nouveau, sous ce regard d'aigle, sous ce regard de mari, elle se sentait coupable, peut-être, a-t-il cru que j'avais envie de partir, peut-être avais-je l'air d'avoir peur, peut-être avais-je peur sans le savoir. Qu'est-ce qui est vrai? Jusqu'ici, ce qui était vrai, c'était ce que disait Jacques; si je ne le crois plus, à quoi pourrais-je croire; elle dit en baissant la tête: 'Je n'aurais pas aimé rester à Paris' ${ }^{352}$.

${ }^{352}$ IBIDEM - pp. 1309 - 1310. 
Jacques então, confortável com a confissão de medo e desamparo da mulher, dorme tranqüilamente enquanto Odette fica a pensar em Mathieu, em quem amava, e que a essa hora da madrugada se apresenta junto com Pinette ao tenente, que os leva até o campanário de uma igreja. O tenente distribui os soldados em alguns estabelecimentos da cidade com a ordem de atirar à vontade, até acabar com as munições. Três soldados ficam com Pinette e Mathieu e se no início não os tratam tão bem (mesmo porque já fazia 15 dias que eles lutavam, enquanto Pinette e Mathieu nunca tinham lutado), aos poucos acolhem esses dois que não gostariam de ficar ali escondidos enquantos outros se batiam por eles.

Quem também decide seu futuro nessa madrugada, começo do dia 18/06, é Boris. Nesse dia ele partiria ou não para a Inglaterra para continuar a luta, mas seria Lola quem daria a palavra final. Ele a acorda de madrugada, e ela o vê, pensa em seu corpo apodrecido, que ele desconhece. A Lola tão servil, apaixonada e ciumenta, aparece aqui de modo totalmente diferente. É ela quem fica sufocada com a presença de Boris, é ela que não sente mais nada, é ela quem se sente sozinha e que guarda um segredo: um tumor no útero que seria necessário tirar (e em sua idade, uma cirurgia como essa podia não dar certo) e sobre o qual ela não contaria para ele.

Percebendo que Boris deseja lhe contar algo e hesita, ela o incentiva e ele enfim diz que se casará com ela e que a levará para morar em uma pequena cidade, na qual daria aulas. Lola se espanta em ver que Boris tinha já arrumado tudo, sem consultá-la, com a certeza de que ela seria feliz se ficasse junto dele... mas ela pergunta se é essa a vida que ele deseja e então vê que é com rancor que ele pensa nesse plano, em viver sem guerrear. Mas o que fazer se a guerra havia terminado? Com essa nova pergunta, Boris conta a Lola que alguns franceses continuam a lutar, que vão até a Inglaterra para continuar a guerrear e que alguns amigos dele iriam no dia seguinte para lá. E embora diga que tenha recusado ir junto com eles porque queria ficar com Lola e porque ela precisava dele, Lola percebe que é mentira (assim como a proteção de Jacques para com Odette era na verdade seu medo) e não exerce até o fím o papel de mulher desprotegida, como a outra fizera. Ao invés de dizer que sim, que precisa da proteção de Boris, o que Lola deseja é romper sua última amarra e diz que se ele quiser partir, não será ela quem impedirá. Ele a agradece demais e se torna, assim, um peso para ela, que já desejava estar no dia seguinte para vê-lo partir e ri, ri por ele se chatear ao ver que ela não estava mal e irritada com a partida dele. 
Odette não se livra dessa amarra, continua a representar o papel de mulher frágil e dependente do marido, mas Lola decide romper, ser livre...livre para morrer (era o que pensava), do mesmo modo como Mathieu estava, às 6 da manhã, de guarda no campanário daquela igreja, vendo os alemães chegarem com infantaria mobilizada. Eles se organizam para defender a escola e a prefeitura mas logo os alemães começam a atirar e explodir granadas.

Mathieu vê um alemão e mira seu fuzil nesse homem que parecia tão frágil, e o mata:

Mathieu regardait son mort et riait. Pendant des années, il avait tenté d'agir. En vain: on lui volait ses actes à mesure; il comptait pour du beurre. Mais ce coup-ci, on ne lui avait rien volé du tout. Il avait appuyé sur la gâchette et, pour une fois, quelque chose était arrivé. 'Quelque chose de définitif', pensa-t-il en riant de plus belle. Son oreille était criblée de détonations et de cris, mais il les entendait à peine; il regardait son mort avec satisfaction; il pensait: 'Il l'a senti passer, nom de Dieu! Il a compris, celui-là, il a compris! Son mort, son oeuvre, la trace de son passage sur la terre' ${ }^{353}$.

Nesses três minutos de batalha (que parecem eternos a Mathieu), o filósofo enfim age, pega o fuzil e mata, age sem que seu ato possa ser "roubado". Os tiros vão e chegam: alemães e franceses continuam a guerra nessa guerra já perdida, com os alemães já tendo invadido Paris. Mas isso parece ser indiferente a esses homens que agora matam e morrem: a prefeitura explode e Chasseriau anuncia que já se passaram sete minutos.

A luta não é contra os alemães mas contra o tempo, o que importa é quanto conseguirão agüentar antes de morrer ou ser preso... dez minutos e a escola também é ocupada: agora só resta o campanário da igreja, é o início do fim, é o momento em que se deve pensar na melhor forma de perder, de eliminar todos os cartuchos antes deles chegarem. Os alemães atiram com canhões e eles já se contentam por terem agüentado doze minutos, hora em que a morte chega também para eles: Chasseriau e Dandieu morrem, Pinette não responde, Mathieu está agora sozinho ali no alto da igreja (e o que é de Clapot?) e atira como louco, para ao menos chegar aos quinze minutos.

${ }^{353}$ IBIDEM - p. 1337. 
Il s'approcha du parapet et se mit à tirer, debout. C'était une énorme revanche; chaque coup de feu le vengeait d'un ancier scrupule. 'Un coup sur Lola que je n'ai pas osé voler, un coup sur Marcelle que j'aurais dû plaquer, un coup sur Odette que je n'ai pas vouler baiser. Celui-ci pour les livres que je n'ai pas osé écrire, celui-là pour les voyages que je me suis refusés, cet autre sur tout les types, en bloc, que j'avais envie de détester et que j'ai essayé de comprendre'. Il tirait, les lois volaient en l'air, tu aimeras ton prochain comme toi-même, pan dans cette gueule de con, tu ne tueras point, pan sur les faux jeton d'en face. Il tirait sur l'Homme, sur la vertu, sur le Monde: la Liberté, c'est la Terreur (...) Il tira: il était tout-puissant, il était libre ${ }^{354}$.

Enquanto atira para todos os lados, vê que passaram quinze minutos de batalha. É assim que essa primeira parte do romance termina: com Mathieu finalmente agindo, atirando nos alemães, mas a forma como age não deixa de incomodar. Ele atira contra todos os valores burgueses que sempre respeitou (mesmo que nunca quisesse), contra a Virtude, a Beleza, o Homem; ele atira para se vingar das pessoas e atos que não ousara fazer: a cada tiro, uma revanche pessoal contra a Moral e o homem que fora. Em nenhum momento a guerra parece estar em questão! Não importam os alemães inimigos, a cidade que deveria defender: o ato que faz não leva em consideração a situação na qual ele se encontra, o concreto mundo real de homens armados na segunda guerra mundial.

Esse grande ato suicida de se colocar em pé no parapeito, alvo fácil dos tiros alemães, e sair atirando em todos os projetos que não ousou realizar não é muito diferente da cena em $A$ Idade da Razão na qual Mathieu crava um punhal em suas mãos para se vingar de todos que exigiam um engajamento seu. Do mesmo modo que se cortara para mostrar a Ivich que também era capaz de atos radicais, para se vingar de seus amigos, de tudo que não tinha dito a eles, agora ele pega o fuzil e atira pensando em tudo que não ousara fazer e desrespeitar.

É certo que ferir a própria mão em uma boate e atirar em alemães numa guerra mundial são atos com dimensões muito diferentes (o primeiro ato diz respeito apenas ao próprio Mathieu, à sua mão; e o segundo diz respeito a todos os franceses e alemães envolvidos na guerra); mas é certo também que o personagem Mathieu não leva em consideração essas distinções tão óbvias: para ele, a guerra não está em jogo, o destino dos alemães e franceses não é considerado em nenhum momento durante

\footnotetext{
${ }^{354}$ IBIDEM - p. 1344.
} 
esse ato - tudo que lhe interessa, à beira do parapeito e da morte, é si próprio, são seus projetos nunca realizados, os beijos e dinheiros não roubados; ele atira contra seu fracasso e contra os Valores; nunca contra os alemães. Embora seja necessário assinalar a distinção que existe entre cortar sua própria mão e atirar, sozinho, em um monte de alemães, para Mathieu, nos dois casos, o que importa é apenas ele mesmo e a revanche.

Nem mesmo mobilizado em uma guerra mundial Mathieu se engaja, faz de sua liberdade um ato que visa a concretude histórica. Inserido numa história impossível de ser negada, Mathieu continua a pensar em Valores, Homem, Mundo, Beleza, continua a pensar no absoluto, na abstração. Os tiros que desfere não são contra homens inimigos com canhões na praça em frente à igreja mas sim contra o Homem.

E ao contrário do que muitos comentadores dizem - de que o desfecho do romance sempre está de acordo com a filosofia de Sartre e por isso é totalmente previsível, Prince diz que

à la fin de L'age de la raison, Mathieu est aussi embarassé de sa liberté qu'au début et nous continuons à nous demander avec lui ce qu'il en fera. Dans Le Sursis, les conclusions auxquelles aboutissent certains personnages ne sont qu'un nouveau point de départ. 'Je resterai libre', pense Mathieu. Et la fin de La Mort dans l'âme projette le lecteur dans le futur: 'Demains viendront les oiseaux noirs'. De même, il n'est pas vrai que les actions des personnages soient prévisibles, qu'elles donnent à ces romans l'aspect d'une démonstration. Au contraire, il est surprenant de voir Daniel épouser Marcelle, de voir Mathieu faire le coupe de feu. Ce dernier épisode montre d'ailleurs très bien à quel point certains critiques se sont trompés parce qu'ils voulaient prouver à tout prix l'existence d'une thèse dans La Mort dans l'âme. Maurice Nadeau prétend qu'on peut facilement prévoir le dernier acte de Mathieu: un héros sartrien doit finir par s'engager. Mais Nadeau n'a pas vu que cet acte n'est pas un acte d'engagement; c'est, au contraire, un acte 'pour rien', manifestation d'une liberté terroriste, non responsable. 'Il tirait sur l'homme, sur la Vertu, sur le Monde: la liberté, c'est la Terreur...' ${ }^{355}$.

Mathieu continua metafísico e abstrato em plena batalha contra os alemães, e só assim é que poderia pensar, no mesmo momento em que atira, que a Liberdade é o Terror, a destruição. A definição de liberdade que dá em sua última cena, na cena em

${ }^{355}$ PRINCE. Métaphysique et technique dans l'oeuvre romanesque de Sartre - pp, 15- 16. 
que dá sua morte como certa e próxima (o que os trechos de um quarto volume nunca concluído mostram ser mentira), é muito semelhante à liberdade que defendera durante $A$ Idade da Razão. É a esse momento destrutivo e absolutamente negativo que Mathieu chama Liberdade; e é ela que deseja e persegue desde a primeira linha de $O s$ Caminhos da Liberdade até a última cena da trilogia.

É claro que podemos dizer que, embora Mathieu deseje essa liberdade-terror, esse não engajamento com nada, esse pairar acima de tudo, com atos extremamente individualistas que visam uma fuga total, tudo isso não passa de ilusão, uma ilusão que se Mathieu pensa alcançar, todos os outros que convivem com ele sabem que não se pode alcançá-la.

Desde o início, como que malgré lui, podemos dizer que o tempo todo Mathieu está totalmente engajado, que todos os atos que realiza para nada assumir implica assumir a fuga, o não engajamento. Os atos que realizou (ou não) não são sem conseqüências para os outros e para ele: o dinheiro que quase roubou de Lola, o filho que não quis ter, o beijo que não tentou com Odette, o casamento que não teve com Marcelle, a guerra na qual aceitou participar - tudo isso modificou a vida dessas pessoas e acontecimentos, tudo isso contribuiu para Mathieu se mostrar esse homem tão abstrato e arrogante, para formá-lo e fazê-lo existir.

Fugir de todo compromisso implica ter o compromisso com a fuga (podemos dizer, como bem sabemos pela teoria sartriana do engajamento, que a condenação à liberdade é também - e ao mesmo tempo - condenação às escolhas e compromissos), mas é do olhar de Mathieu que partimos e agora terminamos, e o que seu olhar vê é a Liberdade como Terror, é a possibilidade da anulação total, do sobrevôo eterno.

Se muitos pensam ver nessa atitude de Mathieu a possibilidade de fuga da máfé, como Albérès (para ele o personagem mostra, nesse terceiro volume, que a coragem consiste em aceitar o mundo $)^{356}$, pensamos que ainda estamos no registro da má-fé. E é o próprio Sartre, em uma entrevista dada em $1945^{357}$, ano de publicação de A Idade da Razão e Sursis, que deixa perceber isso: nessa entrevista, ele comenta que Mathieu, ao fim do segundo volume (como já citamos), não era realmente livre, tentava sempre se colocar fora da história, e que no final da trilogia ele se engajaria livremente.

${ }^{356}$ Cf. ALBÉRÈS. La révolte des écrivains d'aujourd'hui.
${ }^{357}$ Cf. SARTRE. Oeuvres Romanesques. 
A idéia inicial de Sartre era, no último romance da trilogia, que se chamaria $L a$ dernière chance, mostrar Mathieu e Brunet engajados livremente; e se faz de La mort dans l'âme o terceiro e não último volume é justamente porque aqui ele não conseguiu ou não quis mostrar esses personagens de modo positivo. $\mathrm{O}$ romance no qual tentará colocá-los "engajados livremente" será La dernière chance, o quarto volume que abandonará sem terminar. Mas aqui ainda temos um Mathieu agindo de modo a tentar se colocar fora da história, no céu abstrato e absoluto de sua liberdade.

E se todos os atos de Mathieu não o livram da lama da concretude histórica (afinal, sua mão é ferida, alemães são mortos, ele é preso), se tudo que faz tem implicações reais, ele ainda nega isso a todo custo, mesmo que o preço a pagar seja a morte. Mathieu deseja a destruição sem o momento da construção, a negação absoluta - e é essa liberdade-terror que pensa alcançar no corte que fere sua mão e nos tiros que desfere sobre os alemães. O filósofo pensa, na última cena, pairar sobre o mundo, assim como sobre o parapeito, ver tudo do alto de sua absoluta abstração e negação, sem tocar os pés na imundície que é a história.

Mas se é a última cena em que Mathieu aparece, não é a última cena de Com a Morte na Alma. Estamos no final da Primeira Parte, e há toda uma segunda parte que se passa centrada em apenas um personagem: Brunet. Enquanto na primeira parte a história se centrava em Mathieu (e alguns outros personagens apareciam de vez em quando - Boris, Ivich, Lola, Daniel, Philippe, Jacques, Odette, Gomez, Sarah), agora todo o resto da história diz respeito a Brunet, unicamente a ele. É como se Sartre tivesse desistido de falar de todos esses outros personagens, tivesse deixado muitos em situação complicada (Mathieu teria morrido?, Boris teria ido à Inglaterra?, Daniel conseguira ter Philippe?, Jacques e Odette chegariam em Juan-les-Pins?), para falar de um que mal aparecia nos outros romances.

Brunet surge em A Idade da Razão conversando com Sarah e depois indo à casa de Mathieu para convidá-lo a entrar no PC, e só reaparece em Sursis ao encontrar Maurice na rua e deixar claro que a filiação de ambos ao Partido não se dá nos mesmos termos, que Brunet era um burguês e Maurice um operário. Apenas nesses poucos momentos ele aparecia; mas é com ele e sua experência de prisioneiro que ficaremos em toda a segunda e última parte do romance. Escolha talvez influenciada 
pelas preocupações contemporâneas de Sartre mas que parece não encaixar muito bem nesse romance ${ }^{358}$.

É então Brunet que acompanhamos nessa segunda parte, marcada por longos parágrafos (em quase 100 páginas, não encontramos mais do que 3 parágrafos), mas com frases curtas, ritmadas por ações e diálogos (bem diferente da primeira parte, com parágrafos não longos mas com mais abstrações) ${ }^{359} \ldots$ ele está à noite, sozinho, em uma cidade na qual também já se vê a aproximação dos alemães. Entra em uma casa que parece vazia para poder descansar depois de oito dias sem dormir, lutando, mas lá encontra um casal que se esconde com uma criança e o aceita a contragosto, exigindo que ele saia da casa no momento em que os alemães chegarem, o que logo acontece. Brunet sai então à rua e vê os alemães nessa pequena cidade, atirando em muitos, sendo atacados por homens no campanário de uma igreja (na mesma cidade em que Mathieu estava? Parece-nos que sim).

Alguns franceses se entregam, Brunet se entrega no momento mesmo em que vê o campanário desmoronar; e os homens põem-se a caminhar pela estrada, seguidos pelos alemães e suas armas... mais de dez mil homens caminham sem saber para onde, controlados por alguns poucos alemães: "C'est marrant; ils pourraient se jeter sur les Allemands; les étrangler, s'enfuir à travers champs: à quoi bon? Ils vont droit devant eux, où la route les mène" ${ }^{360}$.

Todos caminham, riem, começam a se apresentar uns aos outros, discutem para onde irão, se voltarão para casa ou se ficarão presos... e Brunet, silencioso, observa e pensa que terá muito trabalho com esses homens (assim como Mathieu, ele não se vê como um igual - enquanto os outros têm cansaço, sede, fome, ele pensa em como organizar esses homens, em como aproveitá-los em prol do Partido Comunista). Diante dessas homens escandalosos, Brunet procura por algum companheiro do Partido, o que seria fácil de reconhecer: "un seul visage dur et calme, un visage d'homme" ${ }^{361}$. Enquanto os comunistas têm rosto de homem, esses que riem e se sentem fracos não parecem homens... é com essa extrema arrogância e superioridade

\footnotetext{
${ }^{358}$ As duas partes do romance parecem dois romances distintos, não relacionados entre si. A única relação que nos aparece é a referência ao campanário da igreja, que nos faz pensar que talvez Mathieu esteja nesse mesmo grupo de prisioneiros franceses, sem reencontrar seu amigo Brunet.

359 "Les trois paragraphes énormes et contés au présent qui constituient la deuxième partie font ressortir à merveille la pression du collectif inerte et de l'immédiat sur Brunet" - PRINCE. Métaphysique et technique dans l'oeuvre romanesque de Sartre - p. 34.

${ }^{360}$ SARTRE. "La mort dans l'âme" In Oeuvres Romanesques - p. 1349.

${ }^{361}$ IBIDEM - p. 1353.
} 
que Brunet (tendo a barba feita, um homem "limpo") vê todos que estavam na mesma situação que ele e que chegam à cidade de Baccarat.

São colocados em uma caserna e ali ficam, em pé, sem saber o que fazer até que um sargento francês pede para todos sentarem, dizendo a Brunet que só era preciso ordenar algo para que todos obedecessem. Sem sentar, vê um outro homem que também continuava de pé e Brunet começa a conversar com ele, Schneider, com um rosto não desconhecido; e os dois, em pé, observam esses homens que começam a brigar com o sargento porque ele queria defender os chefes, que tinham abandonado esses homens. E o que esses simples soldados poderiam fazer se Pétain pedia o armistício e os generais discutiam em castelos? Para o sargento, mesmo assim era preciso lutar; para os outros era necessário chefe e ordem - e eles não eram responsáveis por perderem a guerra.

Mas se discutem muito sobre isso, é só quando o sargento os acusa de não trabalharem muito e de pensarem em greve que um deles, Blondinet, passa à violência - e Brunet pensa haver algo a tirar desse homem que tanta importância dá ao trabalho. E se é nisso que Brunet pensa, Schneider tenta intervir e olha estranhamente para o novo amigo, que ainda zomba de um homem que espera por comida e nem pensa na guerra, causando um comentário um tanto ácido da parte de Schneider: "'C'est difficile d'aider les gens quand on n'a pas de sympathie pour eux"'362.

Sentindo-se reconhecido, Brunet (cuja foto aparecia várias vezes no jornal L'Huma) se defende, dizendo não ter ilusões, mas sentindo cada vez mais curiosidade em saber quem era esse homem que parecia tão intelectual e que ao mesmo tempo se identificava com os outros ali sentados e alienados. E enquanto pensa no método para aproximar esses homens do PC ("il faudra détruire un à un, patiemment, leurs espoirs, crever leurs illusions, leur faire voir à nu leurs condition épouvantable, les dégoûter de tout, de tous et, pour commencer, d'eux-mêmes. Alors seulement...") ${ }^{363}$, Schneider parece ler seus pensamentos e diz que será difícil dar uma consciência a esses homens, que não são uma classe mas sim uma manada e Brunet tem então a certeza de que o outro o reconhecera.

A noite chega, e ao juntar toalhas e cobertores para dormir, um grupo começa a se formar: Lambert, Moûlu, o sargento, o Ch'timi, Blondinet, Brunet e Schneider dividem suas coisas e se dizem já companheiros. E na conversa que esses dois

\footnotetext{
${ }^{362}$ IBIDEM - p. 1363.

${ }^{363}$ IBIDEM - p. 1364.
} 
continuam a ter, tão cheia de discordâncias sobre a guerra, a perda, ambos mentem: Brunet não diz o que faz e acha que Schneider também mente. Ambos se calam e dormem, não sem Brunet tentar decifrar quem é esse homem que ao mesmo tempo é tão humanista (sente a dor e sofrimento dos outros, coisa que Brunet não sente) e tão cruel (sabe que não voltarão para casa, que vão morrer e não tem esperança, como Brunet tem).

Na manhã seguinte, quando um caminhão entra pela porta, todos acham ser comida e se juntam, atropelam um ao outro para chegar mais perto do caminhão que estava vazio, que trazia um alemão com um pedaço de pão nas mãos, e que deixa cair perto do caminhão. Esses homens, como animais, disputam esses pedaços jogados e caídos. E por não poder salvar todos dessa selvageria que tanto diverte os alemães, Brunet se contenta em segurar um desses homens e impedi-lo de comer, até que o caminhão vai embora; o que não é suficiente: o homem impedido de se humilhar, quando libertado por Brunet, humilha-se ainda mais: tenta pegar um pedaço que ainda vê e é pego pelos alemães.

Brunet ri e ouve a voz de Schneider: "Tu ne nous aimes pas beaucoup" 364 . O que Schneider recrimina em Brunet é o fato deste não compreender os momentos de humilhação, sentir fome como eles sentem, e Schneider diz saber quem é Brunet e este o convida para trabalhar com ele, o que aquele aceita, dizendo não ser camarada mas também não ser contra eles.

E se no início Brunet continua a se manter limpo (lavando-se, fazendo exercícios), e a recrutar camaradas (o que o narrador chama de Typo encontra Perrin que vai procurar outros), aos poucos suas pernas não mais o obedecem e ele cai, não consegue mais se levantar, dorme, sonha, delira até que Schneider o acorda para the dar uma sopa. "Brunet se met à rire: c'était ça, ce n'était que ça. Cet immense désir coupable, ce n'était que la faim" ${ }^{365}$. E a cada sopa e pão, ele se sente melhor, já consegue se sentar e conversar. Encontra Schneider com Typo e começam a caminhar, a ver esses homens que já se sentem em casa naquela caserna, a ver padre que reza missa, prega o programa político de Pétain e atrai cada vez mais soldados; coisas que irritam Brunet: "Il a suffit d'une bouché de pain! Une bouché de pain, et cette cour sinistre où agonissait l'armée vaincue s'est changée en plage, en solarium, en

\footnotetext{
${ }^{364}$ IBIDEM - p. 1379.

${ }^{365}$ IBIDEM - p. 1389.
} 
kermesse" ${ }^{366} \ldots$ esses homens se acostumaram com a prisão e nem pensam que os alemães são tão ruins assim, já que até comida eles fornecem.

Schneider pergunta a Brunet no que exatamente iriam trabalham e este começa a mostrar seu plano: como não há mais Partido, sindicatos ali, seria necessário reconstituir alguma coisa, ao menos uma contra-propaganda clandestina que recuse a reconhecer o armistício e que pregue que a democracia é a única forma de governo que eles podem aceitar. Embora isso seja muito pouco, é muito perante as circunstâncias e os homens. Schneider concorda, diz que o ajudará mas ainda quer saber se é isso que realmente o Partido ordena, ao que Brunet diz apenas saber que muitos estão mortos e que com certeza a ordem do Partido agora era se reorganizar. Schneider, porém, não se contenta: a cada resposta de Brunet, ele coloca uma outra interrogação, outra contestação, outra crítica.

$\mathrm{O}$ que o incomoda é ver que Brunet, um filiado ao $\mathrm{PC}$, estabelecia um programa que não sabe se o próprio PC aprovaria. Ele não é comunista e por isso ajudará Brunet de qualquer modo, mas se fosse comunista gostaria de saber sobre quais bases o PC estava agora se reorganizando: se a URSS eram aliados da Alemanha, como o PC poderia tomar posição firme contra o nazismo? Isso não prejudicaria a URSS? Mesmo com relações cortadas entre o Partido e a URSS, o PCF não poderia se impor um silêncio para não causar dificuldades à URSS?

Brunet se irrita com as acusações mas Schneider continua a criticar, dizendo que Brunet está trabalhando no escuro, sem saber exatamente o que agora o PCF deseja. Brunet então ri, diz que pretende agora apenas se colocar contra os padres e nazistas e depois, aos poucos, veriam o que fazer.

Sozinho, Brunet pensa no que Schneider dissera e crê que o Partido não poderia abandoná-lo: junta-se então ao pessoal de sua tenda e todos, nesse começo de noite, relembram o que faziam nessa hora em tempos de paz, nas mulheres que amavam, nos vinhos, filmes, músicas... um homem começa a cantar e todos sonham com os tempos antigos - apenas Schneider nada fala e Brunet percebe isso, desconfiado que o amigo oculta muita coisa.

Na manhã seguinte, Brunet e os camaradas fazem ginástica e se banham, mas basta ver que uma nova notícia chegara para que todos, menos Brunet, fiquem ansiosos. A esperança que este queria rejeitar voltava ao olhar desses jovens, mesmo

${ }^{366}$ IBIDEM - p. 1391. 
para os comunistas, os "homens de verdade". Mesmo esses se alegram ao saber que haverá visita de familiares ali na prisão, mesmo eles são humanos no sentido que Brunet não deseja que eles sejam: "Brunet déteste les petits bonheurs immérités qui viennent combler de temps en temps les coeurs lâches, un rab de soupe, la visite des damilles, ça complique le travail" ${ }^{367} \ldots$ tudo que Brunet consegue pensar é que as mulheres e mães irão infectar esses jovens com o mito heróico do prisioneiro, tornando-os ainda mais impenetráveis ao trabalho, ao PC.

Mas algo começa a mudar nessa prisão: os familiares poderão visitar os presos e os alsacianos são libertados porque a Alsácia retornará à Alemanha, levando-os, não sem uma certa vergonha no início (a qual, porém, logo passa) a estender as mãos e gritar "Heil Hitler". E no lugar da raiva, o que os outros franceses mostram, ao ver os alsacianos indo embora, é inveja - o que irrita Brunet, que chama Schneider para conversar.

Novamente a conversa se dá nos mesmos termos, com Brunet se mostrando o tempo todo irritado com esses homens que ali estavam (o socialista que ontem fazia parte do grupo hoje gritava Hitler), e Schneider criticando-o por não amar esses homens tão fracos. E enquanto Brunet despreza todos esses covardes, Schneider mostra a ele que a França, hoje, é esses homens e se Brunet não os atingir, para nada todo esse trabalho servirá:

Mais oui, regarde-moi, regarde-moi donc; prends ton air de médecin des morts. Cent fois je t'ai surpris en train d'observer les copains de tes yeux froids, on aurait dit que tu faisais un constat. Eh bien? Qu'est-ce que tu constates? Que je suis un déchet du processus historique? D'accord. Déchet tant que tu voudras. Mas pas mort, Brunet, pas mort, malheureusement. Ma déchéance, j'ai à la vivre, c'est un goût dans ma bouche, tu ne comprendras jamais ça. Tu es un abstrait et c'est vous tous, les abstraits, qui avez fait de nous les déchets que nous sommes ${ }^{368}$.

Assim como Brunet criticava Mathieu por esse não se engajar, por ele se mostrar abstrato e não se filiar ao Partido, Schneider critica Brunet por este, no seio do partido, continuar abstrato, por aprovar um acordo de não-agressão que levou à guerra

\footnotetext{
${ }^{367}$ IBIDEM - p. 1411.

${ }^{368}$ IBIDEM - p. 1425.
} 
que diz não querer ${ }^{369}$... e por não ver que, mesmo pensando ainda estar no Partido e fazendo o que ele desejava, Brunet estava tão arruinado e solitário quanto todos, também estava com a "morte na alma". Mas se os dois sempre discutem, eles também sempre continuam juntos. As discordâncias não impedem que ambos continuem a lutar, mesmo que com tantas divergências - e Brunet não entende muito bem porque isso se dá.

$\mathrm{Na}$ hora da visita dos familiares, vão olhar (Schneider quer ver os civis e Brunet quer sentir os companheiros próximos) esses poucos homens e mulheres que visitam os presos, e até mesmo Brunet se emociona e se encoraja com os olhares e palavras dos civis, o que faz Schneider também se emocionar e lembrar de sua esposa, foto de quem mostra para Brunet.

O dia oscila entre as críticas e ajudas, desânimo e esperança... Brunet briga com Schneider mas quando ambos vêem os civis, não só voltam a se compreenderem como também voltam a ter esperança no trabalho que querem fazer... esperança essa que não é eliminada nem pelas falas desanimadas dos camaradas do PC nem pelos companheiros, que se irritam ao saber que um homem fugira sendo que os alemães nada fizeram para provocar a fuga. Nessa noite de desamparo e desânimo, Brunet e Schneider conversam e falam da amizade e do quanto um sentiria falta do outro caso resolvessem fugir; mas ambos sabem que não fugirão.

E como não fogem, são colocados em um vagão de trem. Todos os prisioneiros dessa cidade de Baccarat são transportados para um lugar que eles não sabem qual é, ou fingem não saber. Acreditam que continuarão na França e alguns acham que serão até mesmo desmobilizados. Typo, encostado em Brunet, pensa em se jogar, tem medo, mas continua ali, por ter um responsável por ele (Brunet) e também por ter esperança de irem a Châlons, como Moûlu dizia e repetia com convicção.

Brunet se sente mal por saber qual é o destino de todos eles, por ver esses jovens e outros nem tão jovens esperando pela liberdade, pela desmobilização que não virá: "Ils la voient, leur libération, ils la touchent presque sur ce paysage, sur ces eaux calmes. La paix, le travail, le vieux rentrera ce soir avec des goujons, dans huit jours

\footnotetext{
${ }^{369}$ Brunet se mostra próximo aos heróis de Malraux, daquele que deseja ser líder e se ver acima dos outros, acha-se superior.
} 
ils seront libres: la preuve est là, insinuante et douce. Brunet se sent mal à l'aise; il n'est pas bon d'être seul à connaître l'avenir" ${ }^{370}$.

Mas ele não é o único a saber. Mesmo que na primeira bifurcação o trem vire à esquerda (indicando assim que estava a caminho de Nancy e Châlons, como o viajante Moûlu, que tão bem conhecia a estrada, dizia), um habitante de Nancy fala que os prisioneiros que lá estavam foram transferidos para a Alemanha, no que os prisioneiros dentro do trem insistem em não acreditar, mesmo que acreditem um pouco. Xingam esse senhor, têm certeza de que ele os enganara, mas voltam a ficar silenciosos e a ter medo da próxima bifurcação... Typo volta a ter muito medo e na conversa com Brunet fala que morreria na Alemanha, que não agüentaria ir até lá e que deseja se jogar do trem; o que Brunet diz impedir (mas lê no olhar de Schneider uma recriminação e percebe que não tem o direito de impedir que o outro morra).

Depois de passar pela segunda bifurcação e continuar à esquerda, causando novamente esperança nesses rapazes, o trem pára e um soldado alemão lhes dá cigarros. A pedido dos prisioneiros, Schneider (que também mostra saber para onde vão) pergunta a esse soldado para onde iriam. E na hora de traduzir a resposta, Schneider diz a verdade: que eles serão transportados para Trèves, em Bochie; e diante desses prisioneiros que insistem em não aceitar essa notícia e a se irritarem, Schneider grita e diz que é para eles acreditarem no que quiserem. Novamente o medo se instala (Typo volta a tremer e é abraçado por Brunet), e nessa oscilação de desespero e esperança, o trem volta a correr e chega à última e decisiva bifurcação. Nesse momento a certeza viria: se o trem virasse à esquerda, era a salvação; se virasse à direita, seria o inferno.

E pelas expressões soltas por Moûlu ("Merda, merda, merda"), todos compreendem que será o inferno. Agora não há mais como ter esperança, como esperar: o trem virou à direita e se encaminha à Alemanha... Typo não suporta e se joga do trem, mas o medo de morrer ali se torna, de repente, maior do que o medo de morrer na Alemanha. Levanta e volta a correr, tenta entrar no trem novamente; e quando Schneider segura Brunet, que se estende para puxar Typo, os alemães atiram e ele cai e morre.

Cenas de desespero, de conflito (os franceses xingam os alemães, que fecham as portas dos vagões), de compreensão (Schneider e Brunet se dão as mãos por alguns

${ }^{370}$ IBIDEM - p. 1442. 
instantes, compartilhando a dor da morte), e de solidão... o romance termina com Brunet, sozinho nesse vagão cheio de homens, sabendo que apenas a noite que corre lá fora continua viva: "Au-dessus du mort et du wagon inerte, la nuit passe, seule vivante. Demain l'aube les couvrira de la même rosée, la chair morte et l'acier rouillé ruisselleront de la même sueur. Demain viendront les oiseaux noirs" ${ }^{371}$.

Amanhã será o inferno, mas é hoje, com Brunet no trem, que o romance fecha a trilogia. Quando a morte na alma se instala, não há mais o que falar, o que escrever.

É assim que a trilogia Os Caminhos da Liberdade termina. Sartre passa de uma história totalmente pessoal de Mathieu no primeiro volume (a gravidez da amante como ameaça ao que ele concebe como sendo sua liberdade) para uma história que admite cada vez mais a impotância da própria história. Em Sursis a ameaça de uma guerra mundial surge e com ela todas as histórias pessoais, que não perdem de modo algum a importância, passam agora a girar em torno de uma história mais ampla, que envolve não apenas os envolvidos diretamente nessa história mas a Europa toda.

Mas se no segundo volume a história surge com força, a ponto de tornar Mathieu apenas mais um personagem entre vários outros, ainda não se passa de uma ameaça de uma guerra, que parece desaparecer no final, trazendo assim uma incômoda paz, um reconforto desconfortante para todos esses personagens que pensavam ter de lutar e descobrem que não terão mais de fazer isso, ao menos por um tempo. Alegria misturada à vergonha... mas mesmo assim ainda é possível sonhar, relembrar o que se fazia em tempos de paz e pensar que esse tempo retornará, quase que intacto.

É apenas em Com a Morte na Alma que a história surge de vez. Sem as esperanças e incertezas do segundo volume, agora estamos em meio à segunda guerra mundial. O romance já se inicia na guerra, no dia em que Paris é tomada pelos alemães, e apresenta novamente Mathieu como o personagem principal (ao menos na primeira parte).

Ele surge com companheiros de guerra, com outros soldados que são abandonados pelos comandantes e que não sabem nem mesmo o que fazer - e por isso esperam, esperam o fim da guerra ou ao menos a prisão, o que era mais certo. Até mesmo o professor de filosofia parece estar "engajado" nessa guerra, lutando ao lado de outros soldados e pegando fuzis para defender uma pequena cidade, para ao menos

${ }^{371}$ IBIDEM - p. 1457. 
sobreviver por alguns minutos a mais ao ataque dos alemães, que chegam. Aqui ele parece finalmente estar próximo à história, agir de modo a modificar os acontecimentos e não para fugir deles. O homem que não queria aceitar o filho e uma esposa porque eles anulariam sua liberdade abstratamente absoluta agora age, e diz que essa ação é sua liberdade.

No entanto, como já vimos, aqui ainda não se trata propriamente de uma inserção consciente. O filósofo age, mata, mas até isso é capaz de fazer de modo abstrato: Mathieu não atira contra os alemães que chegam e atacam a cidade mas sim contra o "Homem", a "Virtude", a "Beleza". Se deseja eliminar de sua vida as abstrações, os conceitos abstratos, realiza isso do modo mais abstrato possível, ignorando que atirava contra alemães e imaginando atirar contra valores e pudores. $\mathrm{O}$ filósofo não compreende, nem mesmo nesse ato que à primeira vista parece ser tão histórico e engajado, que lutar contra os valores e conceitos abstratos é justa e simplesmente matar os alemães, agir de modo concreto, pensando nos alemães mortos e não nos atos que fizera ou não fizera e dos quais se arrepende.

E se abandonamos Mathieu nesse ato tão radical e ao mesmo tempo tão abstrato, talvez seja para mostrar um personagem que soube exercer concretamente sua liberdade e não apenas de modo negativo: Brunet, o camarada do Partido Comunista Francês, é quem aparece na segunda parte do romance como personagem principal. Prisioneiro em um campo para soldados franceses, talvez seja o homem que melhor agiria de modo concreto, tentando modificar a situação de todos. Talvez o jornalista do alto escalão do PC, tão preocupado com o desenrolar histórico que levaria à revolução socialista, mostre-se engajado conscientemente nesse acontecimento que ao mesmo tempo é tão universal e tão individual.

Mas também não é isso que ocorre na segunda parte do romance. Pelos olhares e falas de Schneider e pelos próprios pensamentos de Brunet podemos perceber o quanto este se vê afastado dos outros companheiros, vê-se acima dos que sofrem e se humilham para pegar um pedaço de pão e se alegram com uma simples visita, a ponto de esquecerem que os alemães são carrascos que devem ser combatidos. Em quase nenhum momento Brunet compreende ou tenta compreender os homens que se encontram na mesma situação que ele - pelo contrário, julga-os de modo rude, superior; e o que deseja não é uma real solidariedade mas fazer desses homens instrumentos do Partido Comunista. Ser parte do Partido não faz de Brunet um homem consciente da condição dos outros homens - assim como a liberdade era fuga para 
Mathieu, o Partido também parece ser uma abstração que permite a Brunet se colocar fora da situação, acima do sangue da história.

Nem Mathieu nem Brunet são personagens que se conscientizam de sua ação, que exercem uma liberdade positiva. Ambos tentam se colocar acima da história, do lado de fora, vendo e julgando os companheiros. Se Mathieu age no final da trilogia, é ainda para confirmar sua liberdade terrorista, e se Brunet parece ter mais preocupações concretas, ele também se coloca acima dos outros, vê a história pelo lado de fora, como um juiz que escolhe os culpados e vítimas.

Apenas no quarto volume vemos a tentativa de aproximação entre ambos os personagens, com Mathieu agindo mais concretamente, reconhecendo-se como parte de um grupo e com Brunet reconhecendo o outro como outro e não mais como instrumento do Partido. Em La Dernière Chance Sartre parece tentar mostrar como a aproximação entre Mathieu e Brunet poderia levar a uma ação livremente engajada, mas o romance não é concluído: apenas alguns fragmentos foram escritos, e isso talvez mostre justamente que não é possível narrar a liberdade inteiramente conquistada. Se há caminhos da liberdade, talvez seja porque não existe um fim ao caminhar.

Assim como a moral anunciada no final de $O$ ser e o nada como necessária nunca foi concluída, assim como a autenticidade como fuga radical da má-fé nunca passou de uma nota de rodapé, de algo que era possível mas cuja descrição não cabia naquele momento - a narração de um homem exercendo plenamente a liberdade construtiva e concreta não é concluída. E nem poderia ser. Concluir uma moral, descrever uma atitude que seja totalmente autêntica, narrar o exercício pleno da liberdade é incluir um conteúdo normativo em algo que se define justamente por ser construído a cada momento, a cada ato e silêncio. A teorização de uma moral e a narração de uma autenticidade e liberdade plenas poderiam determinar um momento no qual elas seriam "congeladas", determinadas... e isso seria a negação mesma da moral e da liberdade.

Uma moral que se define como contrução contínua não pode ser teorizada, transformada em um edifício já totalmente construído. E uma liberdade que se define como exercício de libertação não pode ser narrada como conquistada, como plenamente vivida. Por isso talvez só seja possível teorizar a má-fé e não a autenticidade, por isso talvez só seja possível narrar o caminho de libertação e nunca a liberdade conquistada. 
Se a história se insere cada vez mais a cada romance, os personagens ainda desejam se colocar fora dela, ao mesmo tempo agindo e querendo conservar uma liberdade que se dê apenas de modo abstrato e negativo. E quando eles parecem ter descoberto a impossibilidade de fuga da história, a necessidade de agir de modo humilde e concreto (sem considerar os homens como instrumentos de algum Partido como Brunet fazia nos três primeiros volumes e sem desconsiderar os outros e querer se colocar acima dos acontecimentos e se manter alheio a eles como Mathieu desejava nesses três livros), Sartre deixa de narrar, talvez porque a arte deixaria assim, de ser tão crítica, correria o risco de se mostrar como possibilidade de abstração, de salvação por meio de uma autenticidade completa que seria, justamente por ser completa, máfé.

E como já vimos em A Idade da Razão e em Sursis, a arte também aparece muito pouco em Com a Morte na Alma, e como um elemento que auxilia na fuga do mundo tão sangrento e sofrido. Apenas em três momentos a arte aparece nesse terceiro volume, e em dois deles ela é vista pelos soldados (em meio à guerra e depois já feito prisioneiros) como o momento em que a paz ainda é possível, em que a lembrança de uma vida feliz surge saudosamente e permite esquecer, mesmo que por apenas alguns instantes, as incertezas e sofrimentos da guerra. Os soldados cantam e ouvem outros cantarem música e põem-se a lembrar como viviam em tempos de paz, romancizando essa época, trazendo novamente alegria para o presente tão tenso e conturbado. A música nesses dois momentos aparece como o meio utilizado pelos soldados para se colocarem momentaneamente fora da história, fora do tempo, no mundo abstrato das lembranças de paz.

No outro momento em que a arte aparece (é na verdade o único momento em que realmente se pensa a questão da arte, de sua importância, no saber se ela é possível diante desse mundo tão duro que é a guerra da Espanha e uma guerra mundial), Gomez, nos EUA, conserva, em termos gerais, essa ilusão da arte, que transforma até mesmo o sofrimento em beleza. Embora ele pareça desiludido com a arte, embora acredite que ela não é mais possível nesse mundo em que vive, o que Gomez mostra é, por um lado, o mesmo conceito de arte que os outros personagens: mesmo que acredite que ela não seja mais possível, ela não o é porque não tem mais como ser abstração desse mundo que não tem como ser abstraído. 
Há, porém, uma outra questão pensada por ele que até agora não tinha sido levantada nos romances de Sartre: o papel crítico da arte. Diante de um estadunidense que diz não aceitar a arte que exija muito do espectador, não aceitar que ela provoque, mostre os traumas de cada um, Gomez nada entende. Para ele, artista que lutou na guerra da Espanha, a arte deve ter também um papel crítico, perturbador. Talvez apenas ele compreenda o aspecto estético e ético que a arte tem, mas dividido entre dois mundos, entre um mundo que não comporta mais a beleza (a Europa sangrando em guerras) e um outro que não aceita a ética (os EUA e a arte do entretenimento) ${ }^{372}$, Gomez se mostra totalmente desiludido e diz que a arte não é mais possível.

Embora Sartre já tenha escrito Que é a literatura? no momento da publicação de Com a Morte na Alma e mostrado, de modo bastante insistente, o papel crítico e concreto da arte, de como essa, se é imaginário, volta-se para o mundo negado sempre mantido como pano de fundo, modificando-o pelo simples fato de nomeá-lo, ou, no caso das outras artes que não a prosa, mostrando, pelo modo como o artista se coloca em sua arte, a maneira pela qual ele compreende o mundo em que vive; em seus romances a arte continua a ser, na maior parte das vezes, momento de fuga, de abstração, de pura negação do real. Desde o Roquentin de $A$ náusea até os soldados franceses presos, uma música ouvida ou cantada se mostra como momentos de ilusão, de ser, de fuga da contingência da realidade humana. Não queremos dizer com isso que a arte significa fuga e nem mesmo que os personagens consigam efetivamente realizar essa fuga impossível. Se Roquentin termina seu diário desejando escrever um romance, nada sabemos do Roquentin autor de romances - e com certeza a escrita do romance não levaria ao fim da náusea. E o mesmo se dá com os soldados de agora: se conseguem instantes de fuga, são apenas breves instantes que não conseguem apagar a realidade nem diminuir o peso de serem prisioneiros. Apenas Gomez compreende o papel desvelador e crítico que a arte também tem, mas justamente quem pensa na arte como beleza e desvelamento é quem decreta que ela não é mais possível nesse mundo de guerras ou da arte como diversão ou "mensagem".

\footnotetext{
372 Não é exatamente o que Sartre diz nesse trecho do romance e não pensamos que ele faz referência explícita a isso, mas na medida em que o estadunidense diz que a arte deve dizer coisas agradáveis, não provocar o público e colocar-se acima de todos os problemas, servindo apenas como fruição leve e agradável, tomamos a liberdade de colocar uma questão que desde essa época já é patente para alguns outros filósofos, como Benjamin.
} 
Mesmo que não exista nenhum personagem que realize o ideal de fuga pela arte, essa aparece quase sempre como o instante de pausa e de beleza, como o meio de realizar a fuga da história, como o modo de alcançar a liberdade abstratamente absoluta que Mathieu tanto desejava. O modo como os personagens pensam a história e tentam desvincular-se dela reflete-se no modo como vêem a arte, mostrando, assim, que há um vínculo estreito entre ambas - e mesmo que Sartre não pense essa relação entre estética e ética do mesmo modo como seus personagens, o que ele desvela é justamente a maneira pela qual costuma-se ver a arte e a história; e no ato mesmo de narrar, de desvelar, volta-se contra essa concepção de arte como possibilidade de fuga da história: pelo contrário, a arte é possibilidade de, com beleza e estilo, desvelar o mundo no qual vivemos, de compreendermos, por meio da descrição singular e imaginária, a história que sofremos e ao mesmo tempo fazemos. É por meio da beleza, do estilo, da abstração momentânea que o imaginário realiza, que o homem pode depois voltar-se para o concreto e melhor compreendê-lo e vivê-lo. Se não se pode desprezar o aspecto imaginário da arte, também não se deve ignorar seu aspecto perturbador e crítico, assim como não devemos separar esses dois aspectos: o imaginário que a arte é vem do real e se volta a ele, sem ser pura abstração e nem uma cópia da realidade. Arte e história se negam e se completam, e se a história pode servir à arte com questões, temas, histórias, esta pode servir a um mais compreensivo desvelamento daquela. E é no ato mesmo de descrever o modo como os homens, em plena segunda guerra mundial, ainda podem pensar em maneiras de fugir da história por meio da arte, ignorando a importância tanto de uma quanto da outra, que Sartre mostra sua concepção de estética internamente relacionada à ética, ao comprometimento com a história.

\section{Conclusão}

Após a tentativa de compreender os romances de Sartre, podemos agora traçar um esboço da relação entre a estética e a ética nas suas obras de juventude e maturidade.

Nos contos de juventude analisados no primeiro capítulo, tínhamos assuntos bastante cotidianos (com exceção de Er, l'arménien, todos os outros tratavam de 
professores ou jovens estudantes - mundo freqüentado por Sartre na época), narrados com pouca preocupação estilística (o autor já tinha formado a idéia do papel do escritor, mas ainda não pensava propriamente nos modos de narração). O principal tema de todos esses contos, a crítica aos valores burgueses, aos homens que ainda tentavam se refugir do mundo concreto sem deuses e valores, era feita por um narrador que se mostrava explicitamente.

A ironia desse narrador, embora não poupasse nem a si mesmo (nos contos em que o narrador era ao mesmo tempo personagem), era explícita e direta demais, mostrando, assim, que seu papel era justamente o de criticar, o de desconfiar desses atributos burgueses cotidianos. O narrador ironiza as tentativas de seus personagens e é ácido com as histórias que conta - e ao exercer esse papel, mostra que a arte deve ser crítica; mas uma crítica que se mostra de forma muito direta, clara e explícita, e portanto, como não artística.

Nos contos de juventude de Sartre a arte desempenha um papel muito crítico mas também muito direto, o que diminui seu valor literário. Ainda não havia uma preocupação claramente literária, estética: a ética parece mais explícita nesses contos que a própria estética, e o papel desse narrador que interfere o tempo todo no que é narrado, que comenta as atitudes de seus personagens, mostra de modo direto demais que a arte deve ser crítica, deve conter um imperativo ético, uma metafísica do autor que é necessário compreender.

Mas se o papel crítico da arte se mostra de forma muito direta e clara devido à presença tão forte do narrador, não é mais isso que vemos nos romances de maturidade - e o efeito da perda do narrador é, paradoxalmente, o de tornar a arte ainda mais crítica, mas de um modo mais literário, menos direto e mais ambíguo, ou seja, de modo a respeitar as preocupações estilísticas e paradoxais que toda arte exige.

Nos romances, o narrador que tanto critica e ironiza seus personagens dá lugar aos vários pontos de vista, aos personagens que dialogam e se mostram ao olhar o outro e ao ser olhado, e seu papel crítico é cedido ao leitor, que deve agora assumir esse olhar irônico, distante mas nunca ausente, que o narrador tinha para com sua própria história e personagens.

Assim, os romances de Sartre se mostram de forma muito mais rica e ambígua, sem um narrador que diga suas opiniões e tente impor um certo tipo de leitura e crítica. Não há mais esse papel direcionador, e com isso os romances se tornam mais 
literários, dando uma maior liberdade ao leitor e exigindo dele um maior comprometimento. Ao conservar os paradoxos da obra de arte, do imaginário, Sartre consegue tornar sua literatura ao mesmo tempo mais bela e mais crítica.

Em A Idade da Razão acompanhamos Mathieu na tentativa de negar sua idade e seus compromissos, mantendo-se acima dos acontecimentos: nem a gravidez de sua amante nem a guerra da Espanha parecem ser capazes de atingi-lo. Ele se mantém calmo, mostra-se inalterado apesar de tudo que lhe acontece: a gravidez, a tentativa de cortejar a jovem Ivich, o médico judeu que fugia, o amigo que estava na guerra da Espanha, o outro amigo que o convida a se juntar ao Partido Comunista. Tudo isso não o atinge verdadeiramente: sua única preocupação é com a manutenção de sua liberdade abstratamente absoluta, que parece não ter relação alguma com a realidade, com os acontecimentos tão "banais" como um aborto ou uma guerra.

Esse personagem tão sólido em sua abstração não se envolve em nenhum acontecimento, busca, ao contrário, fugir de toda espécie de comprometimento, tudo para conservar sua liberdade abstrata, que para nada serve. E nos poucos momentos em que se encontra diante da arte (em um museu e depois ouvindo Lola cantar), pensa que apenas ali era possível sofrer de modo belo, que a arte exige um modo de contemplação que não era o modo real. Assim como sua liberdade, a arte também parece ser uma maneira de tentar se manter acima e alheio à história.

Mas se Mathieu assim tenta viver, se se pretende livre porque não se engaja, porque acha que é possível se manter o tempo todo acima dos acontecimentos (seja não assumindo suas ações seja contemplando a arte), Sartre mostra, em seu ensaio Que é a Literatura?, que a fuga pelo imaginário não é possível, ou melhor: que na própria fuga nos inserimos ainda mais no mundo que tentamos negar, que o descomprometimento exige o compromisso com o descomprometimento.

O personagem principal de $A$ Idade da Razão não relata, portanto, as mesmas preocupações e idéias do autor do romance, e essa discordância acaba por intensificar o caráter crítico da obra de arte, a principal tese de Sartre a respeito da literatura. Para ele, a arte é fruto da consciência imaginante que nega o real e o mantém como pano de fundo, voltando-se o tempo todo para ele. Não há propriamente uma fuga do real, e a negação que a arte opera só é possível porque o mundo é mantido como pano de fundo, é olhado a cada instante, a cada negação. E é justamente devido a esse movimento de negação e volta ao mundo que a arte se mostra capaz de espelhar de 
modo deformado a realidade, nossas ações - e ao nos vermos nesse espelho retorcido, temos de tomar uma posição em relação à imagem vista; seja para negar, transformar ou assumir, o leitor precisa se posicionar. A arte se mostra crítica justamente por ser ambígua, por ser o movimento em direção à abstração e a queda brusca na concretude histórica, por revelar, com seus paradoxos, o que somos.

E essa crítica, tão explícita nos contos de juventude mas colocada de modo tão pouco literário, mostra-se muito mais intensa quando Sartre narra personagens negativos sem a presença do narrador que o critica e dele zomba: desse modo, é mais provável que o leitor se identifique com o personagem e depois tenha que se posicionar sobre a imagem que vê, ou seja, sobre si mesmo, sobre esse homem patético que se pretente livre porque se recusa a viver, ou melhor, porque pensa que é possível recusar o viver, o comprometer-se. Um personagem positivo poderia encarnar o papel de "exemplo", de "descrição de autenticidade"; já o personagem negativo que é Mathieu mostra melhor quem somos, nossas tentativas fracassadas mas sempre recomeçadas de fugir e não nos comprometermos com nossas ações. E mesmo que o leitor se assuma como Mathieu, mesmo que ele continue sentado confortavelmente em seu sofá (do mesmo modo como Mathieu termina o romance), não será mais de forma alheia e ausente, não será mais sem assumir sua falta de crítica e sem se comprometer com sua covardia.

Já em Sursis o plano parece se modificar radicalmente. Uma guerra mundial aproxima-se dos personagens e todos, mesmo aquele que se preocupava unicamente consigo mesmo, terão agora que colocá-la como horizonte de suas ações. E para melhor mostrar essa guerra que ameaça surgir em todos os lugares e para todos os personagens, Sartre opta por fragmentar a narração, por embaralhar as falas e descrições de tal modo que o leitor não sabe mais quem fala, a qual personagem tal frase se refere.

Temos uma multiplicação de personagens e de pontos de vista, de modo a desvelar mais completa e complexamente essa guerra que aparece e torna mais patente a desfragmentação originária. A história surge então com força no segundo volume dos "caminhos da liberdade" e poderíamos pensar que isso significa um passo a mais em direção à consciência de nosso engajamento, de nosso comprometimento com a concretude histórica que se dá não só nos momentos de guerra mas em todos os momentos. Mas se há momentos de extrema lucidez, em que nossa liberdade e 
contingência - e portanto, nossa responsabilidade - é percebido de modo angustiante por Mathieu; o final do romance ainda mostra os franceses aliviados por terem conseguido a paz por mais alguns instantes, por ainda pensar que é possível não se engajar nessa guerra que Anna e Milan já sentiam e viviam.

O final de A Idade da Razão e de Sursis são desconfortáveis: se se percebe livre para nada, se percebe que liberdade implica ação e comprometimento, Mathieu continua confortavelmente sentado em seu sofá sem nada fazer e agora muitos personagens se mostram esperançosos com esse fim de guerra, com a paz que volta a ser possível (mesmo que o preço disso seja dar maior poder à Hitler e entregar a Tchecoeslováquia). E até mesmo Mathieu parece ter essa esperança.

Novamente estamos diante de um romance que mostra personagens que ainda tentam se manter alheios e acima da história. Mesmo que isso aconteça agora às vésperas de uma guerra mundial, é o que muitos personagens desejam e se muitos vão para a guerra, é de modo indiferente, como se isso não os transformasse. Até mesmo às vésperas de uma guerra mundial, algumas pessoas tentam se manter indiferentes em relação à história - e a arte surge para "amenizar" esse clima tão pesado e para dar a esperança de que a paz é ainda possível.

Continuamos, portanto, com a mesma técnica já apresentada em $A$ Idade da Razão, a de apresentar personagens negativos, que não agem nem pensam na arte do mesmo modo que Sartre, para assim permitir uma maior identificação do leitor com os personagens, para que aquele se veja refletido e tenha que refletir sobre suas ações e tentativas de fuga. Ao retratar personagens negativos, Sartre torna sua arte mais crítica, confirma sua teoria de que a arte, se permite um afastar-se do real por ser negação dele, volta-se a ele para melhor e mais criticamente compreendê-lo.

E essa técnica é intensificada em Com a Morte na Alma. O terceiro e último volume terminado de Os Caminhos da Liberdade mostra os personagens em meio à segunda guerra mundial, no dia em que Paris é tomada pelos alemães, em que a guerra se anuncia como perdida para os franceses.

Mas se é um romance que se passa em meio a uma guerra, com conflitos sendo narrados, novamente é a tentativa de se manter acima da história que vemos. Até na última cena em que Mathieu aparece, quando fica de pé no parapeito de uma igreja e atira nos alemães, podemos ver mais um ato suicida, egoísta (seus pensamentos eram se vingar do que não fora capaz de fazer) e abstrato (são tiros dados contra a Virtude, 
o Homem) do que uma inserção consciente na história, em uma guerra perdida e na qual ainda é necessário matar os vencedores.

E se a segunda parte do romance abandona Mathieu para se juntar a Brunet, o homem do Partido Comunista que talvez saberia mostrar o que é uma ação histórica consciente, ainda não é isso que vemos. Através das falas e comportamento de Brunet e de Schneider, percebemos o quanto o primeiro também se pretende acima da história, superior por fazer parte do Partido e não se render e se humilhar como os outros. Do mesmo modo que a liberdade abstratamente absoluta dava a Mathieu a falsa segurança de que os acontecimentos não o atingiam, agora é o Partido Comunista que dá a Brunet a falsa sensação de estar acima dos outros homens e das inseguranças que toda ação implica.

Os caminhos da liberdade parecem ser um longo caminho - é, na verdade um caminho interminável. E se nos três volumes por nós analisados Sartre insiste em mostrar homens que tentam fugir da história, é para melhor mostrar que essa fuga é impossível, é para mostrar que por mais que tentemos nos manter indiferentes e acima da história, utilizando muitas vezes a arte para essa fuga, continuamos inseridos e comprometidos em cada acontecimento, seja com a amante grávida e a jovem que tentamos conquistar, seja em meio a uma guerra, seja na arte.

Sartre não completou o volume La Dernière Chance, no qual narrava Mathieu e Brunet conscientes de suas ações, não mais se justificando com valores abstratos (seja o partido seja a liberdade), porque talvez fosse impossível completar esse caminho da liberdade, mostrar uma liberdade totalmente assumida e vivenciada (o que muito dificilmente se diferenciaria da má-fé, de nos definirmos por uma liberdade plena, pela completude e não pela busca e incompletude que somos). O que resta aos personagens é continuar a percorrer os caminhos da liberdade, talvez mais conscientes de que a tentativa de fuga da história por meio de valores e da arte ainda implica uma inserção no mundo. A tentativa de manter-se acima da história só é possível na própria história, e a arte, se é negação do real, é negação que necessita voltar-se para ele.

Com as tentativas frustradas de Mathieu e de outros personagens, Sartre nos mostra que fazemos e sofremos a história mesmo quando desejamos fugir dela - e que a arte, ao invés de ser instrumento de fuga, mostra-se como meio de mais profunda e criticamente compreendermos o real e nosso desejo necessário de nos abstrairmos dele. Com uma metafísica que só pode ser pensada como história, sem separar os dois 
conceitos, Sartre nos revela uma arte que é movimento de abstração em direção à metafísica e queda necessária na história.

Diferente de Malraux, para quem a arte, mesmo em La Condition Humaine, parece oscilar entre uma metafísica e uma história concreta demais (um certo tom jornalístico da literatura, como Tchen mostra), em Sartre vemos uma metafísica que só tem sentido na história, e por isso sua arte se permite ser ao mesmo tempo busca de abstração e retorno ao real, não em um movimento vão, mas em um movimento que, ao se afastar do real, ao deformá-lo, permite uma volta mais compreensiva e ao mesmo tempo mais crítica. Sem ser totalmente fantástica e nem totalmente jornalística, a obra de arte é e revela o movimento entre a metafísica e a história, o absoluto e o concreto, mostrando como nossa tentativa de fuga é ao mesmo tempo uma inserção e comprometimento maior na história. 


\section{CONCLUSÃO \\ A QUESTÃO ÉTICA}

Após a tentativa de compreender os romances de Malraux e de Sartre, podemos agora traçar um esboço da relação entre a estética e a ética nas suas obras de juventude e maturidade.

$\mathrm{O}$ que vemos nos contos de juventude de cada um não poderia ser mais antagônico, com Malraux descrevendo mundos fantásticos nos quais personagens irreais enfrentam várias lutas em busca de novos sentidos e significados nesse mundo caótico após a morte ou caduquice de Deus; e com Sartre descrevendo o cotidiano, o dia-a-dia de adolescentes e jovens burgueses nos ambientes que ele próprio freqüentava. Enquanto um inicia seus escritos da forma mais fantástica e abstrata possível, o outro começa do lado oposto, quase sem sair do real, quase confundindo fíç̧ão com uma má autobiografia.

Isso pode ser visto não só através do que é narrado como também por meio do modo como cada um narra suas histórias: o fantástico de Malraux é descrito por imagens inesperadas (frutos que estouram e se transformam em Pecados, a morte com esqueleto de alumínio) e palavras inexistentes (o jovem escritor, ligado ao cubismo literário, gosta de juntar várias perspectivas em um só plano, de juntar uma palavra à outra para formar uma nova e separar uma mesma palavra para modificar seu significado), enquanto o cotidiano de Sartre é narrado também de forma cotidiana, sem grandes preocupações lingüísticas.

Mas se nos contos de juventude Malraux e Sartre parecem exercer a estética de modo oposto um ao outro, aos poucos essa divergência diminui consideravelmente: nos romances, não vemos mais Malraux divagando com acontecimentos fantásticos e nem Sartre tão preso ao real: um caminha em direção ao outro, o primeiro em direção ao concreto e o segundo em direção à ficção. Essa aproximação preserva, no entanto, as distinções radicais já vistas em relação à estética e à ética.

De forma geral, tanto em Les Conquérants quanto em La Voie Royale e La Condition Humaine vemos Malraux mudar seu estilo de narrar: o fantástico e o absurdo tão presentes em seus contos iniciais cedem lugar à descrição de acontecimentos reais (a Revolução Chinesa e a viagem do autor à Indochina em busca de esculturas) e as imagens inesperadas cedem lugar às descrições das cidades e selvas orientais (evitando o exótico) e aos sotaques dos personagens. 
Mas se o estilo muda, se a arte agora se volta para a história, as preocupações de Malraux continuam as mesmas: as ações heróicas e a arte permanecem meio de se tentar negar o caos do mundo sem valores, de se tentar fugir desse mundo no qual Deus não mais tem espaço. $\mathrm{O}$ ato grandioso e heróico importa, na maior parte das vezes, não porque se volta contra a opressão real mas porque essa luta representa simbolicamente a luta maior e metafísica contra o absurdo destino humano. E a arte, se passa a narrar acontecimentos reais, continua a ser negação desse mundo caótico para se tentar criar outro mundo, no qual seria possível encontrar uma nova noção de homem.

Les deux grandes passions de Malraux, l'histoire et l'art, sont sans doute celles de son siècle. Et pourtant, paradoxalement, cette double passion lui aura permis de résister à la tentation à laquelle son siècle aura cédé plus d'une fois: celle de réduire l'art à l'histoire, de chercher dans l'histoire une clef pour percer l'énigme de l'art. A l'opposé de tout historicisme, Malraux n'a cessé de mettre em évidence le caractère énigmatique de la création - et son independance à l'égard de l'histoire ${ }^{373}$.

Mesmo que com uma mudança radical na forma e conteúdo da narração, Malraux continua a conceber uma arte como oposição ao real, como tentativa de ao menos se buscar valores, os quais não são mais possíveis no mundo que matou Deus e ao mesmo tempo o homem (apenas no terceiro romance, La Condition Humaine, Malraux dá realmente importância à história, e a arte agora oscila entre a busca metafísica e a crítica moral e real. Mas veremos isso melhor a seguir).

Já Sartre não mostra uma mudança tão radical quanto a de Malraux. Embora apresente mais preocupação em relação ao estilo, à construção dos personagens, L'age de raison, Le Sursis e La mort dans l'âme continuam a narrar o cotidiano dos personagens (quase todos franceses e burgueses) e Mathieu continua a ser o alter-ego que Sartre sempre coloca em suas ficções.

Se a guerra surge em Sursis não é porque os personagens de Sartre saíram de uma certa abstração e procuraram a história (caminho esse mostrado por Malraux), mas porque ela se torna o cotidiano para os europeus. Seu surgimento modifica a relação dos personagens entre si e com o mundo, mas não substancialmente. Nem mesmo o surgimento da guerra no horizonte parece modificar o modo como a maioria

${ }^{373}$ ZARADER. Malraux ou la pensée de l'art-p. 1. 
dos personagens lida com a história e a arte. Tanto os personagens dos contos de juventude quanto os do romance procuram meios de fugir da história, de não se comprometer com os acontecimentos, e vêem a arte (nos pouquíssimos momentos em que ela aparece) como um dos modos de se alcançar a abstração.

Mas se isso ocorre não é porque Sartre defende essa fuga por meio da arte e a busca de novos valores: o que o filósofo faz é colocar em cena personagens negativos que, na tentativa fracassada de fugir, mostram melhor o quanto a arte é crítica (e não uma crítica direta por meio de um narrador onisciente que comenta sobre os personagens e acontecimentos mas por meio de pontos de vista que enfatizam a subjetividade e exigem um olhar crítico e comprometedor do leitor). "A arte fala da realidade ao se renunciar a falar dela, é desse modo que a negação é ao mesmo tempo desvendamento"374.

A arte, nos romances de Sartre, mostra-se como desvelamento das ações humanas, como algo que reflete e pede que reflitamos sobre nossos atos - e se permite um afastar-se do real, se possibilita aos personagens uma certa fuga, isso se dá por apenas alguns segundos: a beleza que faz surgir logo desaparece, o instante de paz logo dá lugar à guerra e ao sofrimento. Se é certo que seus personagens buscam o esquecimento da história por meio da arte e desengajamento, é certo também que com isso Sartre pretende mostrar que sua arte não é fuga mas sim a inserção crítica no real, o desvelamento de nossas ações e tentativas de fuga, e é o que no terceiro romance Gomez começa a perceber.

E na medida em que a estética é, para ambos, crítica (seja crítica à falta de valores do mundo contemporâneo, seja crítica à necessidade burguesa de se criar um novo quadro de valores - tendo, assim, Malraux como crítico de Sartre por este "estimular" o mundo caótico; e Sartre como crítico de Malraux por este continuar a buscar seriamente essências e tábua de valores), ela pode e deve ser relacionada a uma ética, ao modo de conceber as atitudes frente aos acontecimentos de sua época.

Malraux se volta cada vez mais para o real, mostra a queda do homem na história já no final da década de 20 , antes que para os europeus surgisse a grande ameaça de uma segunda guerra mundial. E nas aventuras heróicas que procuram os personagens tentam negar o caos do mundo sem Deus, tentam construir, por meio de

${ }^{374}$ SILVA, Franklin Leopoldo e. Ética e Literatura em Sartre - p. 222. 
grandes ações e ficção heróica, uma nova moral. A arte de Malraux, na medida em que se apresenta como contrária ao real, revela uma crise metafísica que tem de ser seriamente combatida: o mundo sem valores deve ser negado e no lugar dele, por meio da arte como fuga e da ação heróica como contraposição, devemos buscar uma nova moral, uma nova noção de homem. Essa é a preocupação ética do autor. "Des Conquérants à La Condition Humaine, s'opère le passage de la réalité esthétique à la réalité métaphysique, où Malraux prétend trouver une réponse et une possibilité de solution au conflit tragique de l'affrontement de l'homme avec l'Histoire - et donc avec le Destin" 375 .

Se nos dois primeiros romances a história está presente, ela perde sua importância diante das questões metafísicas da luta contra o Destino e da busca de valores. É apenas no terceiro romance, La Condition Humaine, que a história passa realmente a interessar aos personagens - e aqui o papel da arte varia entre a busca metafísica e a crítica concreta às opresssões; e a ética passa a não ser mais apenas a busca ideal por uma moral que substitua Deus morto mas a preocupação concreta em relação à violência e a dignidade.

No entanto, não há aqui uma verdadeira relação entre esses dois modos de se viver a estética e a ética: ou elas continuam a ser fuga, tentativa de não se inserir no mundo (caso de Gisors no final do romance) ou passam a se relacionar de modo muito direto com o real (caso de Tchen, para quem a arte se torna quase jornalística, testemunho). Ou a arte é busca metafísica ou crítica concreta às opressões, e ambos os caminhos parecem ser paralelos. Apenas May esboça uma continuação entre ambos ao falar do sofrimento que leva à vida e não à morte, mas é "apenas" uma mulher e portanto, não é personagem de ação no romance. A arte mostra um outro lado, mais concreto e crítico, mas não há uma conciliação e relação entre o lado metafísico e o lado histórico da arte.

Podemos notar uma mudança semelhante nas obras de Sartre.

O filósofo também mostra, embora mais de dez anos depois de Malraux, como o homem passa da alienação à história, como essa surge e envolve todos os personagens. Mas não há aqui questões metafísicas de reconstrução de uma moral, nem a saída do fanstástico para a busca de guerras: Sartre parte de questões

\footnotetext{
${ }^{375}$ FREITAS, M. Création artistique et histoire chez Malraux: Les Conquérants et La Condition Humaine - p. 307.
} 
individuais para questões sociais, mudança essa causada pela guerra que surge. Mesmo que a contragosto, mesmo que desejem fugir da história e pensem apenas em seus próprios problemas, os personagens agem e interferem no social. Eles não desejam participar da história, nem do modo heróico e superior como os personagens de Malraux: "Sartre a, comme les hommes de son temps, analysé la condition humaine. Mais alors que Malraux en faisait sentir le tragique, il en a surtout senti la laideur, cet avilissement continuel qui menace l'homme en raison de se impuissances (...). Mais l'ascèse de Malraux se réalise dans l'éxotisme et dans l'aventure, celle de Sartre par les moyens de l'ennui et par le dégoût qu'éprouvent ses héros à l'égard de leur vie banale",376; e o modo como vêem a arte revela a tentativa de fugir e se abstrair do real; tentativa no entanto que é sempre frustrada: a arte, para Sartre, se permite um breve esquecimento da guerra, logo se volta para ela.

E é justamente a carga ética da arte que o pintor Gomez percebe no terceiro romance, em La mort dans l'âme. A história surge com mais força ainda - estamos em meio à segunda guerra mundial, logo após a tomada de Paris - e parte dos personagens, mesmo que de modo extremamente egoísta, já não recusam mais a participação ativa na sorte coletiva - e aqui o papel da arte varia entre o momento de pausa, de paz e fuga e o de crítica corrosiva à sociedade; e a ética passa a ser não mais a tentativa de se manter individual e abstratamente livre mas também diz respeito à relação com os outros e com o mundo, mesmo que de forma contrariada.

A arte é o movimento em direção à abstração e a queda necessária no mundo concreto do qual não temos como escapar, une a metafísica com a história, mostra nossa tentativa de fuga e ao mesmo tempo a inserção cada vez mais profunda na realidade que tentamos ignorar. E é esse movimento que Sartre nos mostra por meio de seus personagens negativos e de sua arte ambígua.

A história surge nas obras de maturidade dos dois autores, mas ela não é vista da mesma maneira. Em ambos há uma certa ambigüidade no modo de se viver a história, mas mesmo essa ambigüidade se dá de forma diferente.

A estética de Malraux nos revela um homem que sai da ficção fantástica para buscar os problemas reais e enfrentá-los, mas continua a fazer isso de modo abstrato, superior, e com a mesma preocupação: a necessidade de reconstruir o homem e a

${ }^{376}$ ALBÉRÈS. La révolte des écrivains d'aujourd'hui - pp. 188-189. 
moral, de reconquistar a ordem perdida após o decreto da morte de Deus. Vemos nesses romances o herói que deseja terminar como governo - e a arte, ao mostrar personagens abstratos e superiores, e ao se mostrar como possibilidade de fuga do real, revela como o autor pensa a história e a moral.

Por outro lado, a estética de Sartre nos revela um homem que, sem sair de suas preocupações cotidianas, vê-se imerso na totalidade destotalizada que é a história. Vemos aqui o indivíduo que termina, mesmo que de modo desconfortável, na história - e sua arte, ao mostrar personagens negativos, tão comuns, e ao se mostrar como tentativa de fuga que só se dá de modo momentâneo, que sempre se encontra em meio ao real, nos revela como seu autor pensa a história e a moral.

Depois de compreender a concepção de arte de Malraux e Sartre, e a maneira como a estética está intimamente ligada à ética, podemos agora melhor compreender como os atos de cada um apresentam pontos em comum com suas obras: o revolucionário que passa a governar com de Gaulle apresenta semelhanças em alguns momentos com o herói abstrato dos contos farfelu que vai em busca da história para continuar, de forma superior e abstrata, sua busca metafísica pela ordem e nova noção de homem. E o indivíduo pequeno burguês que evita qualquer participação política, que não vota e que depois passa a ser engajado em todos os acontecimentos mundiais apresenta semelhanças em alguns momentos com o personagem que, pensando apenas em si, vê-se, devido aos acontecimentos que faz e ao mesmo tempo sofre, em meio à coletividade.

Sem reduzir os autores aos personagens, sem reduzir a estética à ética e esta àquela, pensamos que compreender a relação entre elas nos permite melhor compreender a arte e ao mesmo tempo as ações de Malraux e Sartre.

Poderíamos, por exemplo, escolher algumas questões essenciais na década de 50 e 60 (bem depois da escrita dos romances) e verificar como Malraux e Sartre agem, comparando suas ações com o modo como seus personagens vivem e então mostrar alguns pontos comuns, traçar algumas encruzilhadas, algumas ressonâncias.

Dentre alguns temas, poderíamos escolher o general de Gaulle e mostrar como Malraux vê nele o grande chefe e líder que sempre retratou em seus romances (sempre há uma "elite" representada pelos velhos sábios e pelos líderes da revolução) e 
semelhante a seus personagens, apoia-o em sua grande e altiva luta pela busca da Ordem perdida e do Poder, outro tema fundamental em seus romances.

E de modo semelhante mas contrário, também poderíamos encontrar pontos em comum entre a relação de Sartre com de Gaulle e a maneira pela qual seus personagens são ironizados e criticados quando cultuam algum líder (caso de Fréderic e seu "mestre" Organte, e de Brunet com o PCF) - a recusa de Sartre em obedecer a de Gaulle é semelhante ao fracasso da tentativa de ser solipsista e alheio à história, de se colocar acima dos acontecimentos. Não existe a figura do líder nos romances de Sartre, e Brunet, quem mais se aproxima dessa imagem, é desmascarado por Schneider e ridicularizado por se pretender superior e acima dos outros, por se achar um líder e chefe dos prisioneiros de guerra. E do mesmo modo que Schneider ridiculariza Brunet, Sartre não reconhece o poder de de Gaulle e sua ânsia por liderança e ordem, sua vontade de restituir valor como os de "pátria".

Os temas da ordem e da reconstrução dos valores podem ser vistos também no modo como Sartre e Malraux lidam com a Guerra da Argélia - o que se torna mais explícito e próximo de nós se pensarmos na visita que ambos fizeram ao Brasil em 1959 e 1960.

Malraux, apesar de ter criticado a tortura (e talvez pela única vez assinado um protesto ao lado de Sartre), continuou a apoiar de Gaulle e a fazer propaganda da pátria francesa, vindo ao Brasil para anunciar que as torturas não mais existiam. Se chegou a condenar uma vez os crimes do governo, no momento seguinte nega a realidade para se manter ao lado do homem que possibilitará a reconstrução da ordem e dos valores, o líder que encarnará o sentido grandioso de História e Homem.

Já Sartre se mantém constantemente contrário à de Gaulle e às suas aspirações megalomaníacas. Ao vir para o Brasil um ano depois de Malraux, foi justamente para ser o "anti-Malraux", para denunciar a tortura e defender os terroristas argelinos, para revelar o que o Brasil tão bem deveria saber: os efeitos da colonização. O papel do filósofo é o de denunciar a violência que o governo exerce sobre os mais fracos, é o de ironizar, tal como o narrador de seus contos de juventude, os que, como de Gaulle, acham-se acima da história, ou melhor, acham-se "A História".

Contra a imagem do herói tão presente nos romances de Malraux, Sartre mostra em seus romances que a história é feita também por pastores como Gros-Louis, por mulheres grávidas como Marcelle e Anna e por paraplégicos, por pessoas comuns e mesmo pelas consideradas "inferiores”. A história não é o general de Gaulle, herói, 
mas os argelinos que sofrem e têm a rebeldia como possibilidade primeira e mais eficaz.

As atitudes que Malraux e Sartre têm diante do general de Gaulle, da guerra da Argélia e na visita ao Brasil são muitas vezes semelhantes às que seus personagens realizam (ou então semelhante às críticas que se faz ao modo do personagem agir, como é o caso de Sartre). Mas se há esses pontos em comum, se as ações dos personagens se cruzam em alguns momentos com as ações de seus autores, não conseguimos estabelecer uma relação que não fosse direta.

Em vários momentos assinalávamos a concordância que havia entre o que era narrado e o que foi vivido por Malraux e Sartre, mas em todos eles fazíamos uma passagem rápida e direta demais, sem levar em consideração as distinções que deve haver entre o mundo narrado e o mundo vivido, a ficção e a realidade. Todas nossas tentativas de estabelecer a relação entre a moral entrevista nas obras literárias e a moral vivenciada pelos autores se mostraram fracassadas, mostraram-se muito diretas, sem que respeitássemos as particularidades de cada modo de expressão e ação.

Por isso decidimos apenas esboçar acima as questões históricas que poderiam ser relacionadas às ações dos personagens e/ou às críticas a essas ações sem, no entanto, realizar a relação, sem explorar como poderíamos estabelecer a passagem entre o que se narra e o que se vive. Contentamo-nos em apenas elencar alguns poucos acontecimentos que poderiam ser comparados com as narrações, algumas poucas questões (a da figura do herói e chefe, a questão da história e da arte) que poderiam ser vistas de modo semelhantes no narrado e no vivido.

Defrontamo-nos com as dificuldades da análise sociológica que foram apontadas por $\mathrm{Lima}^{377}$ e citadas por nós na introdução: embora continuemos a defender a tese de que há uma relação entre a estética e a ética, de que a concepção de arte concorda com uma certa concepção de ética, a qual poderíamos comparar com as atitudes de Sartre e Malraux, não vemos como passar de uma a outra sem de certo modo identificar o que é ficção e realidade.

Talvez, para ter êxito, fosse necessário nos livrarmos não apenas das idéias mas também das palavras que tanto refletem as noções de causalidade e identidade; ou

${ }^{377}$ Cf. LIMA. Teoria da literatura em suas fontes. 
melhor, talvez fosse preciso nos afastar ainda mais da lógica e fixidez de uma filosofia que se pretende estruturalista.

Sem conseguir mostrar a relação dos escritos com as atitudes dos autores (ao menos do modo como desejava nos início, sem estabelecer causalidades e identidades), ao menos podemos tentar esboçar algumas questões mais gerais, como a do contexto em que os romances foram escritos e quais os sentidos e questões levantados por eles nesse contexto - e é o que tentaremos agora.

Podemos dizer que essa modificação no modo de desvelar a história nos romances de Malraux reflete e é refletora das mudanças ocorridas na Europa entre 1928 e 1933, data da publicação dos dois livros.

Os franceses, em meados da década de 20 , pareceram "ter deixado para trás a guerra e a perturbação pós-guerra" ${ }^{378}$, pensando que isso só seria possível com o esquecimento da história. E se agem, não o fazem para construir, mas para destruir o que sobrou da guerra. O Partido Comunista Francês, embora tivesse a perspectiva de fundar uma França comunista, pensava que em primeiro lugar era necessário negar, destruir e derrotar a burguesia com seus valores morais caducos que tentavam voltar.

Boa parte dos intelectuais, em meados da década de 20, age negativa e absolutamente, não coloca como tema a construção e pretende ignorar mesmo a história - na medida em que deseja destruir absolutamente, destrói também o mundo, faze épokhé dele e permite-se um certo quietismo, já que nega a construção e se rende à instantaneidade de tudo.

E não seria justamente essa a atitude dos principais personagens de Les Conquérants publicado em 1928 e de La Voie Royale publicado em 30? Garine e Perken, os heróis dos romances, sempre agem contra o destino absurdo e os burgueses, buscando, nessa ação, não a construção de algo diferente mas apenas o momento destrutivo. A ação lhes interessa formal e absolutamente, como fim e não como meio. Se lutam ao lado dos chineses e tribos não é porque sua sorte lhe interessa mas porque com eles é (ainda) possível confrontrar e destruir a burguesia.

Assim, Malraux mostra nesses dois livros o modo como boa parte dos intelectuais franceses (principalmente os surrealistas) pensa a história e a ação nessa época. Diante da guerra que insiste em não sair da memória, resta ou não agir, ou agir

\footnotetext{
${ }^{378}$ HOBSBAWN. Era dos extremos, p. 43.
} 
de forma destrutiva, tentando eliminar o passado burguês, que levou à guerra e sobreviveu a ela.

Mas em 1933, ano em que La Condition Humaine é publicado, torna-se muito mais difícil ignorar a história. Com a Queda da Bolsa que se inicia no final de 1929 e atinge seu pior momento em 1932-33, com forças políticas do militarismo e da extrema direita assumindo o poder no Japão em 1931 e na Alemanha em 1933 (mas com os eleitores do centro e da direita já passando em número maciço para o Partido Nazista em 1930, 31), com o Japão invadindo a Manchúria em 1931, "uma nova guerra era não apenas previsível, mas rotineiramente prevista. Os que atingiram a idade adulta na década de 30 a esperavam" ${ }^{379}$.

De 1928 a 1933, tudo muda. Se antes era possível pensar que uma guerra igual à primeira não mais viria, que uma paz eterna era possível, agora só se pode pensar isso por medo de que tudo acontecesse novamente (o que o governo francês faz até às vésperas da nova guerra).

Novas questões urgentes surgiam e era preciso se posicionar frente a elas. Contra o perigo do nazismo que crescia, era preciso não só combatê-lo, mas combatêlo propondo outra coisa. É isso que o PCF fará no início da década de 30: se colocará de imediato contra o nazismo e o fascismo e abrigará como companheiros de estrada vários intelectuais que não eram propriamente comunistas. Os intelectuais franceses vão ao encontro dessa idéia e se unem ao PCF na luta contra os novos perigos: "en pareille circonstance, la seule tactique efficace, particulièrement pour les intellectuels, était celle d'une large alliance avec tous les éléments antifascistes" ${ }^{380}$.

Tanto o PCF quanto os intelectuais começam a agir contra o nazismo propondo, no lugar dele e dos valores burgueses, uma revolução. Símbolo dessa união, a AEAR (Associação dos Escritores e Artistas Revolucionários) é criada em 1932, tendo Malraux como membro. Mesmo que não aderindo totalmente ao PCF, mesmo tendo grandes divergências com ele, o que importava aos escritores era a luta conjunta contra o nazismo em prol de uma modificação radical no país, fosse ela o comunismo ou não. E é essa luta conjunta e ativa por uma revolução que vemos em La Condition Humaine de Malraux, incluindo até mesmo o tema das divergências em relação a um Partido Comunista e sua ortodoxia.

\footnotetext{
${ }^{379}$ IBIDEM - p. 43.

${ }^{380}$ CAUTE, D. Le communisme et les intellectuels français, p. 123.
} 
Assim como Les Conquérants e La Voie Royale revelavam a posição de grande parte dos intelectuais franceses diante da ação e da história no final da década de 20, momento no qual ainda era possível agir em vista apenas da negação e da destruição, La Condition Humaine desvela o intelectual francês no início da década de 30, diante da ascensão do nazismo e de uma nova guerra que já se podia prever, quando era necessário mergulhar nela e agir buscando uma nova perspectiva (embora sempre seja possível negar a história, como Sartre ainda fazia no início da década de 30). Mas é também o surgimento da história que até mesmo Sartre mostrará alguns anos depois, no final da década de 30 e começo de 40 .

Se em A Idade da Razão tratava-se de uma guerra que poucos levavam a sério, em Sursis ela surge com força em meio a discursos de governantes e de convocações para se entrar na guerra. Em poucos meses, o modo como esses personagens levam a guerra em consideração parece se modificar muito e; concordando com a idéia de Hobsbawn de que "quanto aos campos de batalha, os nomes de ilhas melanésias e assentamentos nos desertos norte-africanos, na Birmânia e nas Filipinas, tornaram-se tão conhecidos dos leitores de jornais e radiouvintes - e essa foi essencialmente a guerra dos noticiários radiofônicos - quanto os nomes de batalha no Ártico e no Cáucaso, na Normandia, em Stalingrado e em Kursk. A segunda guerra mundial foi uma aula de geografia do mundo" ${ }^{381}$, Sartre desfragmenta seu romance e o localiza em várias cidades, mostrando, por meio dos personagens tão diversificados, que a guerra que surge tão imperiosa parece ter, no entanto, significações bastante diferentes. Um acontecimento que engloba tantos países e junta as mais diversas condições sociais e econômicas em um mesmo drama não poderia ser visto de um único modo; mas todos, até os mais ignorantes (caso da criança e de Gros-Louis), são atingidos diretamente pela guerra que ameça surgir no horizonte, ainda mais quando o Acordo de Munique é assinado.

Como os personagens são multiplicados e cada um ganha grande importância, não nos é possível estabelecer uma relação única entre as questões que são levantadas pela época e que estão presentes nos romances, mas aqui também há vários elementos dispersos que refletem e são refletores das questões que importava aos franceses nessa guerra mundial, como a do papel do intelectual no Partido Comunista, dos judeus que

${ }^{381}$ HOBSBAWN. Era dos extremos - pp.31 - 32. 
precisam refugiar-se, da felicidade e ao mesmo tempo mal-estar por terem assinado o Acordo de Munique - descrição essa muito semelhante ao que conta Hobsbawn:

O acordo de Munique de 1938 demonstrou perfeitamente essa combinação de confiante agressão de um lado, medo e concessão do outro, o que explica por que durante gerações a própria palavra 'Munique' se tornou sinônimo, no discurso político ocidental, de retirada covarde. A vergonha de Munique, sentida quase imediatamente mesmo por aqueles que assinaram o acordo, estava não apenas em entregar a Hitler um triunfo fácil, mas no palpável medo de guerra que o antecedeu, e na ainda mais palpável sensação de alívio por tê-la evitado a qualquer custo ${ }^{382}$.

De uma maneira bastante dispersa, própria a uma guerra que torna mais forte a sensação de desfragmentação, vemos em Sursis muitos temas que se mostram essenciais para os europeus, não só em 1938 mas também na época da publicação do romance - 7 anos depois.

E se Com a Morte na Alma continua a retratar o intelectual ainda perdido em meio mas que ao menos começa a agir (mesmo que diga ignorar a concretude de suas ações), é sintomático que Sartre dedique toda a segunda parte do romance a Brunet, explicitando os conflitos que o Partido Comunista Francês já exibia em 1940 e que continuava a ter em 1949, ano da publicação do terceiro volume. "A primeira contingência que se teve de enfrentar foi o imediato colapso da grande aliança antifacista. Assim que não mais houve um fascismo para uni-los contra si, capitalismo e comunismo mais uma vez se prepararam para enfrentar um ao outro como inimigos mortais ${ }^{\text {"383 }}$. A crescente expectativa em relação ao papel do PC no final da guerra e nos rumos que o país adotaria se revela junto com os problemas e incoerências do partido (e talvez, mostrar Brunet e Mathieu juntos em La Dernière Chance, com o primeiro abandonando a pretensa superioridade do partido e com o segundo agindo sem tanto teorizar, seja fundamental para um leitor que se encontra no mundo da guerra fria que começa).

Assim, mesmo que de forma muito mais difusa, Sartre também revela em seus romances muitos dos modos como os europeus viviam a guerra ou evitavam vivê-la.

\footnotetext{
${ }^{382}$ IBIDEM - p. 148.

${ }^{383}$ IBIDEM - p. 177.
} 
Mas apenas indicar essas concordâncias dos temas levantados pelos autores e as questões relevantes pela época que os leu é muito pouco.

Fracassamos, portanto, na análise estética e também na análise ética, na teoria literária e nas questões históricas. Mas como mostramos em vários momentos em nossa tese, o fracasso é interpretado de maneira bastante distinta por Sartre e Malraux, e esperamos ao menos que nosso fracasso se identifique mais com o fracasso sartriano, com o "quem perde ganha".

Se o fracasso para Malraux parece tornar todos os atos indiferentes (já que não há mais valores, não há como valorar a vitória e o fracasso), parece levar sempre a um choro sem indicações de novos atos e/ou significações em relação ao que foi feito, o fracasso em Sartre deve sempre levar a uma nova ação e ao menos serve para indicar e conscientizar, a cada tropeço, que não é possível fugir da história e da crítica que toda arte é.

O fracasso sartriano mostra o quão concreto e engajado somos e desvela nossa incompletude ontológica, o Para-si em movimento constante em direção ao "si" que nunca seremos, mas a quem, ao mesmo tempo, está vedado não buscar, não dirigir-se ao que nunca será.

Esperamos que o fracasso por nós admitido seja compreendido no sentido sartriano, no sentido de tornar válido o caminho, mesmo sem completá-lo, no sentido de tomar consciência de que a completude é enganadora, pressupõe uma conclusão, um acabamento que não são próprios ao Para-si que somos:

L'inachèvement de la réalité humaine que décrit l'ontologie est la condition de sa moralité et de son histoire. Si 'le regard ressort de l'histoire est la liberté comme négativité', c'est que le négatif participe au travail de l'histoire sous toutes ses formes, psychologiques et individuelles, comme l'émotion ou l'image, sociales et matérielles, comme la rareté et le praticoinerte. En ce sens, l'interprétation du caractère humain de tout oeuvre doit restituer sa part d'inachèvement, comme l'effet objectif de sa nature intentionnelle et active. Inachever le réel, c'est le transformer en moyen pour une fin qu'il n'est pas encore, c'est donc, concernant les conduites humaines, considérer qu'elles pourraient et devraient être autrement. L'imperfection 
signifie la perfectibilité comme visée, la liberté devenant l'expérience de la négativité comme exigence de sens et de responsabilité dans 1'histoire ${ }^{384}$.

A imperfeição, o inacabamento e o fracasso não devem levar ao total desânimo e inação, devem mostrar, ao contrário, que é necessário continuar a caminhar, que só existe o caminho e não o fim dele e portanto, que não há como paramos de agir, de pensar, de caminhar. Ao narrar o fracasso, Sartre nos mostra que não há como fugir da história, que somos a história que negamos, e que por isso mesmo, nunca alcançaremos uma completude, a qual só poderia ser dada por um "fim da história", se nos colocássemos totalmente fora dela, o que não é possível.

O surgimento da história é, aliás, o tema principal dos romances de Sartre e Malraux. Ambos mostram, mesmo que em épocas bastante distintas, personagens que “ingressam” na história, seja porque vão em busca dela a fim de superá-la, seja porque fogem mas são assaltados por ela. Mas não há como fugir da história que somos (que fazemos e ao mesmo tempo sofremos) e é esse fracasso que Sartre mostra, enquanto que o fracasso de Malraux (seus personagens também fracassam e choram ou morrem no fim de seus romances) ainda deixa o leitor com o gosto do imtemporal, com o gosto da possibilidade de abstração e superação.

Em Sartre, mesmo quando seus personagens continuam a tentar agir de modo abstrato, parece ficar claro ao leitor que essa tentativa é fracassada e deve ser criticada. Já em Malraux parece que o fracasso dos personagens revela mais a necessidade de se continuar a buscar valores e novas noções de homem do que a necessidade de consciente e criticamente viver e compreender a história.

Sartre mostra homens que querem fugir da história, e não consegue. E Malraux mostra homens que se movimentam na direção oposta, homens que querem a todo custo se engajar na história, e não conseguem. O fracasso nos dois autores parece apontar para caminhos contrários: para um gosto amargo e concreto da história (no caso de Sartre) e para um gosto doce e sublime do Intemporal (no caso de Malraux) o que, ao final, apresenta semelhanças com os caminhos traçados pelos dois autores (com Sartre cada vez mais presente nas questões sociais de seu tempo e com Malraux cada vez mais ausente, pensando nos meios abstratos de se opor a esse mundo que não mais aceitava de Gaulle).

${ }^{384}$ GUIGOT. Sartre, liberté et histoire - p. 237. 
Como mostra Gaudeaux, Sartre e Malraux, dois aventureiros e engajados, nunca se encontram inteiramente juntos. Há desejos em comum entre eles: o de se fazer sozinho, de escapar à infância e ao mundo dos adultos, de ser sem ligações, indo de hotel em hotel, de mulher em mulher, a camaradagem como meio de ser com os homens: "Néanmoins, tout les sépare. Malraux, hanté par la mort, cherche à se faire tuer partout; Sartre, toujours heureux, choisit la vie à travers toutes les conjonctures. Leur approche des livres, du monde et des hommes sera différent. (...) Adultes, écrivains reconnus, l'un s'immerge dans le monde pour le transformer, l'autre, même dans les combats, contemple le monde comme un décor" 385 .

Assim, embora a história surja com força para os dois autores, eles a narram com intenções opostas: um vai ao encontro dela para superá-la e o outro tenta fugir dela mas se vê imerso na historicidade, mesmo no momento em que tenta dela escapar. Poderíamos dizer, para terminar com uma imagem literária (relativamente já usada para se falar de Malraux mas não muito de Sartre) que o primeiro mergulha na história e o segundo nela se afoga.

A sensação que temos ao ler os romances de Malraux, e que muitos comentadores assinalam, inclusive Sartre, é que ele teve o grande mérito de ir em busca da história e narrá-la, de ir aonde a história se fazia urgente - Indochina e Espanha - para vivê-la e posteriormente torná-la ficção. Também nos seus personagens podemos perceber um caminhar semelhante: eles saem de uma Europa organizada e em paz (ao menos nos três romances que analisamos) e vão em busca da guerra, do conflito, de uma "História". Mas se assim o fazem, se mergulham na história que pensam ser a verdadeira história, é porque a todo momento acham que são capazes de sair dela, de alcançar o que está para além do concreto. Do mesmo modo que quem mergulha em um rio tem como objetivo, ao menos na maior parte das vezes, chegar ao outro lado, sair do rio, os personagens de Malraux agem, vão ao encontro de onde a história parece ser mais importante, mas fazem esse percurso para encontrar o sentido, a vitória contra o caos do mundo sem Deus e sem valores - ou seja, mergulham na história para sair dela, para ir além dela, do outro lado do rio.

Já Sartre não mergulhou de modo algum na história, pelo contrário, tentou se manter muito tempo fora dela: mesmo que denunciasse, por meio de seus

\footnotetext{
${ }^{385}$ GAUDEAUX. Engagements et marxismes chez Jean-Paul Sartre - p. 199.
} 
personagens, que essa tentativa não passava de ilusão, má-fé, Sartre mesmo não fazia esforço algum para participar da história. Não votava, evitava pronunciar-se sobre política e as situações que vivia, mas então a segunda guerra mundial surge e nada disso é mais tão facilmente possível. Também em seus personagens vemos semelhantes caminhos: eles se afogam nessa história da qual não querem participar de modo inesperado (ao menos para esses que insistem em negar a realidade), ela surge com força e afoga quem se encontra próximo. E embora quem se afogue também deseje - e com mais ânsia que aquele que mergulha - sair do rio, sua convivência com este é mais profunda, mais real, e presente de tal modo que ele descobre que o rio não era só aquilo que inicialmente imaginava, mas que o rio da história se encontra em todos os momentos, não só nas guerras e conflitos mundiais, mas também no dia-a-dia e até mesmo na tentativa de fuga da história. Se talvez seja uma "História" que provoque o afogamento, esse ato revela que tudo é história, até mesmo a vida pacata e tediosa de um historiador em Bouville. Muitos dos personagens de Sartre tentam sair da história, mas, ao se afogarem nela, aprendem que, mesmo que saiam do rio, terão para sempre as marcas e cicatrizes dessa luta contra (e portanto também com) a história. 
“Cerro, o senhor vê. Contei tudo. Agora estou aqui (...) Sei de mim? Cumpro (...) Amável o senhor me ouviu (...) Pois não? O senhor é um homem soberano, circunspecto. Amigos somos. Nonada (...) É o que digo, se for... Existe é homem humano. Travessia."

Guimarães Rosa (Grande Sertão: Veredas) 


\section{BIBLIOGRAFIA}

\section{OBRAS DE MALRAUX:}

- Malraux. "Lunes en Papier" In Oeuvres Complètes I. Paris: Pléiade, ed. Gallimard, 1989;

. "Écrit pour une idole à trompe" In Oeuvres Complètes I. Paris: Pléiade, ed. Gallimard, 1989;

. "La tentation de l'Occident" In Oeuvres Complètes I. Paris: Pléiade, ed. Gallimard, 1989;

- "Les Conquérants" In Oeuvres Complètes I. Paris: Pléiade, ed. Gallimard, 1989;

. "La Voie royale" In Oeuvres Complètes I. Paris: Pléaide, ed. Gallimard, 1989 ;

• "La Condition humaine" In Oeuvres Complètes I. Paris: Pléiade, ed. Gallimard, 1989;

• "Royaume-farfelu" In Oeuvres Complètes I. Paris: Pléiade, ed. Gallimard, 1989;

. Oeuvres Complètes II. Paris: Pléiade, ed. Gallimard, 1996;

. Oeuvres Complètes III. Paris: Pléiade, ed. Gallimard, 1998;

. Entrevista com Malraux feita por Guy Suarès, e distribuida pelo INA Institut Nacional de l'Audiovisuel (France, 1986 - ...);

- Entrevista de Malraux à Radioscope na época da publicação de Antimémoires;

. Vídeo "De Gaulle Malraux: portraits croisés", produzido por France 3 e INA;

- Vídeo "André Malraux", com 5 retratos de Malraux, produzido por La Cinq (France) e Welcome e INA. 


\section{OBRAS DE SARTRE:}

. Sartre. "L'âge de raison" In Oeuvres Romanesques. Paris: Gallimard, 1981; . "Le Sursis" In Oeuvres Romanesques. Paris: Gallimard, 1981; . "La mort dans l'âme" In Oeuvres Romanesques. Paris: Gallimard, 1981; - "L'ange du morbide" In Écrits de Jeunesse. Édition établie par Michel Contat e Michel Rybalka. Paris: ed. Gallimard, 1990;

- "Jésus la Chouette - professeur de province" In Écrits de Jeunesse. Paris: ed. Gallimard, 1990;

- "La semence et le scaphandre" In Écrits de Jeunesse. Paris: ed. Gallimard, 1990;

. "Une défaite" In Écrits de Jeunesse. Paris: ed. Gallimard, 1990;

. "Er l'arménien" In Écrits de Jeunesse. Paris: ed. Gallimard, 1990; - Que é a literatura? São Paulo: ed. Ática, 2004;

- L'imaginaire. Paris: Gallimard, 19??;

. Situações I. São Paulo: Cosac Naify, 20005;

. O ser e o nada. Rio de Janeiro: ed. Vozes, 1999;

. Fala de Sartre em maio de 68, na Sorbonne, gravada e reproduzida pela Biblioteca Nacional da França;

. Entrevista de Sartre para a rádio Radioscope, feita por Jacques Chancel e produzida pela Radio France;

- Conferência "Les écrivains durant la guerre", dada no Canadá no ano de 1946;

.Entrevista com Sartre sobre o papel do intelectual no movimento revolucionário;

- Sartre inédit: vídeo com entrevistas e testemunhos de Sartre, produzido pela Rádio Canadá, 1967. 


\section{COMENTADORES:}

- Albérès. La révolte des écrivains d'aujourd'hui. Paris: ed Corrêa, 1949;

- Andrieu, C. e Braud, P. e Piketty, G. Dictionnaire De Gaulle. Paris: éditions Robert Laffont, 2006;

- Aron, R. L'opium des intellectuels. Calmann-Lévy, 2004;

- Aronson, R. Camus e Sartre: o polêmico fim de uma amizade no pós-guerra. Rio de Janeiro: Nova Fronteira, 2007;

- Auerbach. Mimesis. São Paulo: Perspectiva, 2004;

- Barthes, R. Le degré zéro de l'écriture. Paris: éditions du Seuil, 1953;

- Belin, G. André Malraux: un écrivain au coeur du siècle. Itália: Timéeéditions, 2006;

- Berne, M. Sartre. Paris: Bibliothèque Nationale de France/Gallimard, 2005;

- Berstein, S. Histoire du gaullisme. Paris: Perrin, 2002;

- Bertholet, D. Sartre l'écrivain malgré lui. Paris: infolio, 2005;

- Blanchot, M. A parte do fogo. Rio de Janeiro: Rocco, 1997;

- Boisdeffre, $\mathbf{P}$ de. Une histoire vivante de la littérature d'aujourd'hui. Paris: Libraire Académique Perrin, 1964; . André Malraux - la mort et l'histoire. Paris: Éditions du Rocher, 1996;

- Camus, A. "A Náusea, de Jean-Paul Sartre” In A inteligência e o cadafalso. Rio de Janeiro: Record, 1998;

- Cândido, A. Literatura e Sociedade. São Paulo: ed. Nacional, 1976;

•___ Noções de análise histórico- literária. São Paulo: Humanitas, 2005;

. __ . O discurso e a cidade. São Paulo, Rio de Janeiro: ed. Duas Cidades, 2004 - O observador literário. Rio de Janeiro: Ouro sobre Azul, 2004;

- Carduner, J. La création romanesque chez Malraux. Paris: Librairie A.G Nizet, 1968;

. Cate, C. Malraux. São Paulo: editora página aberta ltda, 2005;

- Caute, D. Le Communisme et les intellectuels français. Paris: Gallimard, 1967

- Chami, A. André Malraux: Quête d'un idéal humain et des valeurs transcendantes. Casablanca: ed. La Croisée des chemins, 2006; 
- Cheyron, J. André Malraux - l'art est une victoire, J. Fombon - Aubenas, 1986

- Chiheb, A. L'esthétique romanesque chez André Malraux et Jean-Paul Sartre dans Les Conquérants, La condition humaine, L'espoir, L'âge de raison, Le sursis et La mort dans l'ame- Tese de doutorado na Université de la Sorbonne Nouvelle - Paris III, 1993;

- Cointet, Michèle. De Gaulle et l'Algérie Française. Paris: Perrin, 1995;

- Courcel, M. Malraux: être et dire. Paris: Librairie Plon, 1976,

- Debate sobre Sartre escritor na BNF, na ocasião do centenário de nascimento, em 2005;

- Denis, B. Literatura e Engajamento de Pascal a Sartre. Bauru: EDUSC, 2002;

. Dreyfus, F. Histoire de la Résistance. Paris: éditions de Fallois, 1996;

. Droz, B. e Lever, É. Histoire de la guerre d'Algérie. Paris: éditions du Seuil, 1982

. Eco, U. Obra Aberta. São Paulo: Perspectiva, 1976;

- Epstein, S. Un paradoxe français. Éditions Albin Michel, 2008;

- Fitch, B. Le sentiment d'étrangeté chez Malraux, Sartre, Camus et Simone de Beauvoir. Paris: Lettres modernes, 1964;

- Freitas, Maria Teresa de. Création artistique et histoire chez Malraux: Les Conquérants et La Condition humaine. Tese de doutorado defendida em 1984 no Departamento de Letras Modernas da USP; - Modernidade e consciência histórica: a ficção literária de André Malraux. Tese de livre-docência defendida em 1991 no Departamento de Letras Modernas da USP;

. Galster, I. La naissance du phénomène Sartre. Paris: éditions du Seuil, 2001;

•___. Sartre, Vichy et les intellectuels. Paris: L'Harmattan, 2001;

- Gaudeaux, J. Engagements et marxismes chez Jean-Paul Sartre, Thèse de le doctorat d'Etat de Jean-François Gaudeaux na Universidade de Lille III - 1999-2000;

- Gaulupeau, S. André Malraux et la mort. Paris: Archives des lettres modernes, 1969;

- Genette, G. Figuras. São Paulo: ed. Perspectiva, 1972;

- Ginzburg. Olhos de madeira. São Paulo: Cia. das Letras, 2001;

- Godard, H. Une grande génération. Paris: éditions Gallimard, 2003; 
- Goldmann, L. Sociologia do Romance. Rio de Janeiro: ed. Paz e Terra, 1976

- Gombrich, E. A história da arte. Rio de Janeiro: ed. LTC, 16ª edição;

- Gomez-Muller, A. Sartre, de La Nausée à l'engagement. Paris: éditions du Félin, 2004;

- Sartre et la culture de l'autre. Paris: L'Harmattan, 2006;

- Grell, I. Les chemins de la liberté de Sartre, genèse et écriture. Berna: Peter Lang, 2005;

. Grover, F. Six entretiens avec Malraux sur des écrivains de son temps. Paris: Gallimard, 1978;

- Guiette, R. La vie de Max Jacob. Paris: A.G. Nizet, 1976;

. Guigot. Sartre, liberté et histoire. Paris: J. Vrin, 2007;

. Harris, G. L'éthique comme fonction de l'esthétique. Paris: Lettres Modernes, Minard, 1972;

-___. De l'Indochine au RPF: une continuité politique (les romans d'André Malraux). Toronto: Les éditions paratexte, 1990;

- Hauser. A. História social da arte e da literatura. São Paulo: Martins Fontes, 2003;

- Hébert, F. Triptyque de la mort. Montréal: Les presses de l'Université de Montréal, 1978;

- Hobsbawn, E. Era dos extremos. São Paulo: Cia das Letras, 1995;

. Institut Charles de Gaulle. De Gaulle et Malraux. Librairie Plon, 1987;

- Jouve, V. Poétique des valeurs. Paris: Presses Universitaires de France, 2001

- Jurt. Guerre civile, exil et littérature. Madri: Iberoamericana, 2005;

- Kpogodo, B. Contestation des valeurs morales et religieuses dans le roman contemporaine (Malraux, Sartre, Camus), doctorat du troisième cycle de Lettres Françaises, Université de Toulouse-le Mirail, 1976;

. Lacouture, J. Les formes diverses d'engagement chez André Malraux - fala à Biblioteca Nacional da França; . Malraux, une vie dans le siècle. Paris: éditions du Seuil, 1973;

- Lalou, R. Histoire de la littérature française contemporaine - tomo I e II. Paris: Presses Universitaires de France, 1947;

. Lantonnet, E. Études sur Malraux et le roman. Paris: ellipses, 1996; 
- Lévy, Bernard-Henry. As aventuras da liberdade. São Paulo: Cia das Letras, 1992;

. Lima, Luiz Costa. Teoria da literatura em suas fontes - volume 1. Rio de Janeiro: Civilização Brasileira, 2002;

- __ . Teoria da literatura em suas fontes - volume 2. Rio de Janeiro: Civilização Brasileira, 2002;

•___ Vida e mimesis. Rio de Janeiro: ed. 34, 1995;

- Louette, J. Sartre écrivain. Paris: Eurédit, 2005;

- ___ Sartre: la littérature, hermeneutique du silence, tese de doutorado apresentado na Universidade de la Sorbonne Nouvelle (Paris III), em 1988;

. Lukács. Teoria do romance. São Paulo, Rio de Janeiro: Duas cidades, Ed. 34, 2007;

- Mauriac. Malraux ou le mal du héros. Paris: ed. Grasset, 1946;

- McGillivray, H. Malraux et la révolte irrationnelle: politique, histoire et culture. Paris: Minard, 2000;

- Moatti, C. Le prédicateurs et ses masques - les personnages d'André Malraux. Paris: publications de la Sorbonne, 1987;

- Morawski, S. L'absolu et la forme esthétique d'André Malraux. Paris: éditions Klincksieck, 1972;

- Mossuz-Lavau, J. André Malraux et le gaullisme. Paris: Presses de la fondation nationale des sciences politiques, 1982;

- Mounier, E. A esperança dos desesperados. Rio de Janeiro: Paz e Terra, 1972

- Münster, A. Sartre: le philosophe, l'intellectuel et la politique. Paris: L'Harmattan, 2006;

- Muracciole, J. La France pendant la Seconde Guerre Mondiale. Paris: Librairie Générale Française, 2002;

- Picon, G. Malraux par lui-même. Paris: éditions du Seuil, 1953;

. Pischel, E. História da Revolução Chinesa, vol. 1. Mira-Sinta: EuropaAmérica, 1976;

- Pomar, W. A Revolução Chinesa. São Paulo: ed. Unesp, 2003;

- Prince, G. Métaphysique et technique dans l'oeuvre romanesque de Sartre. Genève: Librairie Droz, 1968;

- Ricoeur, P. Du text à l'action. Paris: éd. du Seuil, 1986; 
- Saint-Cheron, F. L'esthétique de Malraux. Paris: éditions Sedes, 1996;

. Saint-Cheron, M. André Malraux ou la conquête du destin. Paris: Bernard Giovanangeli Éditeur, 2006;

- Sapiro, G. La guerre des écrivains. Paris: Librairie Fayard, 1999;

- Sawada, N. Écriture et morale: question éthique chez Sartre, Thèse de Doctorat à l'Université de Paris 1, 1993;

. Schwarz, R. A sereia e o desconfiado. Rio de Janeiro: Paz a Terra, 1981;

- Scriven, M. J.P Sartre: politique et culture dans la France de l'aprèsguerre. Jaignes: La chasse au snark, 2001;

- Serroy, J. De Gaulle et les écrivains. Grenoble: Presses Universitaires de Grenoble, 1991;

. Silva, F. Ética e literatura em Sartre. São Paulo: Unesp, 2004;

- Soares, C. Sartre e o pensamento mítico. Dissertação de mestrado apresentada à Faculdade de Filosofia da USP em 2005;

- Souza, T. Sartre e a literatura engajada: espelho crítico e consciência infeliz. São Paulo: Edusp, 2008;

-___ O mito de Er: Sartre e o platonismo às avessas? In Cadernos de Ética e Filosofia Política, v. 8, 2006.

- Stéphane, R. Portrait de l'aventurier. Paris: Grasset, 1965;

- Tadié. Le roman au XXe. siècle. Paris: Pierre Belfond, 1990;

. Todorov, Tzvetan. Les genres du discours. Paris: Éditions du Seuil, 1978;

•___ Poética da prosa. São Paulo: Martins Fontes, 2003.

- Vandegans, André. La jeunesse littéraire d'André Malraux. Paris: J.JPauvert, 1964;

- Vandromme, Pol. Malraux, du farfelu au mirabolant. Lausanne: Alfred Eiel éditeur, 1976;

- Verstraeten. Autour de JP Sartre: littérature et philosophie. Paris: éditions Gallimard, 1981;

- Viansson-Ponté, P. Histoire de la République gaullienne I. Paris: Fayard, 1970

- Villemot, D. André Malraux et la politique - l'être et l'histoire. Paris: L'Harmattan, 1996;

- Watt, I. Ascensão do romance. São Paulo: Cia das Letras, 1996;

. Winock, Michel. Le siècle des intellectuels. Paris: éditions du Seuil, 1997; 
- Wittmann, H. L'esthétique de Sartre - artistes et intellectuels. Paris: L'Harmattan, 2001;

- Wormser, G. Sartre, violence et éthique. Lyon: Sens Publique, 2005;

•___. Sartre, du mythe à l'histoire. Lyon: Sens Publique, 2005;

- Zarader, J. Malraux ou la pensée de l'art. Paris: ellipses, 1998;

- Histoire de l'art IV - du réalisme à nos jours, Encyclopédie de la Pléiade. Paris: éd. Gallimard, 1969. 